Florida International University FIU Digital Commons

\title{
Epistemologías culturales del Caribe: modelos conceptuales metafóricos en el ensayo caribeño del siglo XX
}

\author{
Diana M. Grullón-García \\ Florida International University, dgrul002@fiu.edu
}

DOI: $10.25148 /$ etd.FI15032193

Follow this and additional works at: https://digitalcommons.fiu.edu/etd

Part of the Comparative Literature Commons, Latin American Languages and Societies Commons, Latin American Literature Commons, Modern Languages Commons, and the Race, Ethnicity and Post-Colonial Studies Commons

\section{Recommended Citation}

Grullón-García, Diana M., "Epistemologías culturales del Caribe: modelos conceptuales metafóricos en el ensayo caribeño del siglo XX" (2015). FIU Electronic Theses and Dissertations. 1759.

https://digitalcommons.fiu.edu/etd/1759 


\section{FLORIDA INTERNATIONAL UNIVERSITY}

Miami, Florida

\section{EPISTEMOLOGÍAS CULTURALES DEL CARIBE: MODELOS CONCEPTUALES METAFÓRICOS EN EL ENSAYO CARIBEÑO DEL SIGLO XX}

A dissertation submitted in partial fulfillment of the requirements for the degree of DOCTOR OF PHILOSOPHY

in

SPANISH

by

Diana M. Grullón-García 
To: Dean Michael R. Heithaus

College of Arts and Sciences

This dissertation, written by Diana M. Grullón-García, and entitled Epistemologías culturales del Caribe: modelos conceptuales metafóricos en el ensayo caribeño del siglo XX, having been approved in respect to style and intellectual content, is referred to you for judgment.

We have read this dissertation and recommend that it be approved.

$\begin{array}{r}\text { Pascale Bécel } \\ \hline \text { Santiago Juan-Navarro } \\ \hline \text { Ana María Bidegain } \\ \hline \text { Erik Camayd-Freixas, Major Professor }\end{array}$

Date of Defense: March 26, 2015

The dissertation of Diana M. Grullón-García is approved.

\begin{tabular}{r}
\hline $\begin{array}{r}\text { Dean Michael R. Heithaus } \\
\text { College of Arts and Sciences }\end{array}$ \\
\hline Dean Lakshmi N. Reddi \\
University Graduate School
\end{tabular}

Florida International University, 2015 


\title{
ABSTRACT OF THE DISSERTATION
}

\section{EPISTEMOLOGÍAS CULTURALES DEL CARIBE: MODELOS CONCEPTUALES}

\section{METAFÓRICOS EN EL ENSAYO CARIBEÑO DEL SIGLO XX}

by

\author{
Diana M. Grullón-García \\ Florida International University, 2015 \\ Miami, Florida \\ Professor Erik Camayd-Freixas
}

El Caribe ha sido reconocido por considerarse una pluralidad de espacios que simultáneamente son solo uno. Contrario al contexto de su fragmentada geografía, su segregada historia colonial y su diversidad racial y lingüística, los intelectuales caribeños han establecido puentes de unidad cultural con la intención de configurar una identidad pancaribeña. Por consiguiente, los ensayistas del siglo XX se enfrentan a la necesidad de examinar críticamente los factores que formulan sus respectivas identidades, en contraste con aquellas tradicionalmente impuestas bajo el discurso colonial y metropolitano. Desde el tercer cuarto del siglo, pensadores como Aimé Césaire (1913-2008), Fernando Ortiz (18811969), Fidel Castro (1926-), George Lamming (1927-), Kamau Brathwaite (1930-), Juan I. Jiménes-Grullón (1903-1983), Hubert Devonish (1953-), Edouard Glissant (1928-2011), Antonio Benítez-Rojo (1931-2005), Arcadio Díaz Quiñones y Maryse Condé (1937-), entre otros, cuestionan el sistema colonial, los procesos étnicos y las propuestas lingüísticas, relacionándolos con conceptos tales como la hibridez, el sincretismo, la transculturación y la heterogeneidad. Estas teorías culturales, de alguna manera, reescriben ideas antecedentes en reacción a discursos hegemónicos previos como consecuencia de los cambios políticos que trajeron las guerras de independencia en América Latina durante el siglo XIX. 
En mi tesis demuestro que estos planteamientos delinean un mapa de modelos epistemológicos de la cultura del Caribe. Para indicar que estas propuestas constituyen metáforas que muestran una consciencia cultural, las proposiciones acerca de la cultura de Jorge Luis Borges (1899-1986) y Hayden White (1928-) sirven como marco teórico apropiado. Así, a través de las representaciones literarias ensayísticas de los modelos metafóricos de la cultura caribeña, este trabajo redefine algunos aspectos importantes de la identidad cultural vis a vis la mirada parcial que usualmente se utiliza para estudiar el archipiélago antillano. Igualmente, incluso aunque estos modelos proponen una representación metafórica de la cultura pan-caribeña, la construcción de un modelo del Caribe puede ser utilizado en otras regiones y espacios culturales en el contexto de la globalización, ya que elucida una gnoseología cultural que sirve para describir distintas realidades globales. 
Introducción

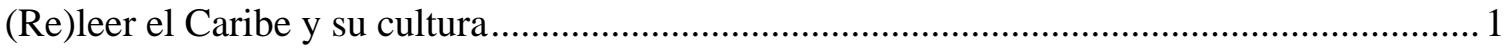

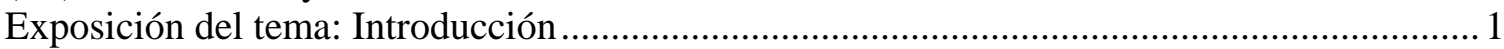

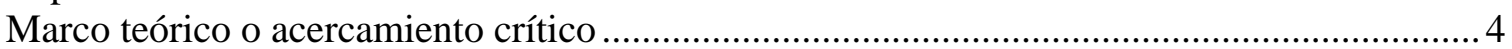

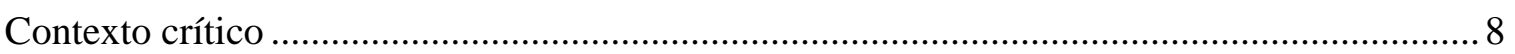

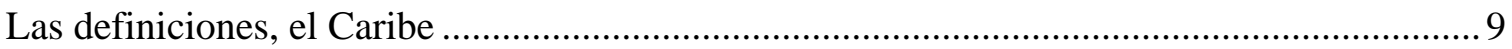

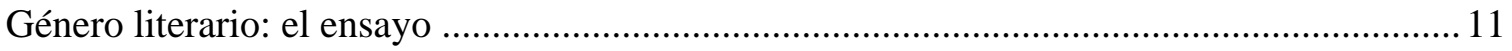

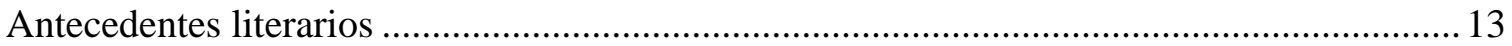

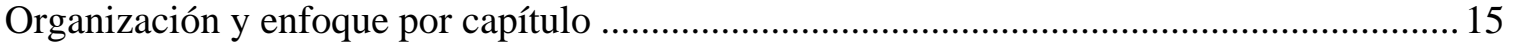

\section{Capítulo 1}

La metáfora racial de lo caribeño: la négritude ............................................................. 18

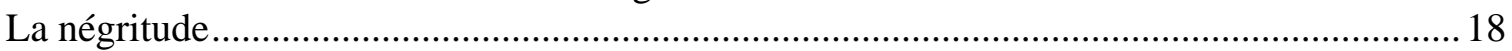

Propuesta de una metáfora: "Négreries: jeunesse noir et assimilation” "................................26

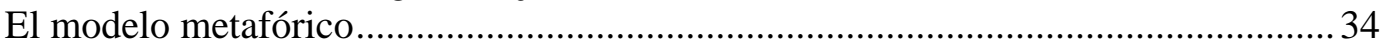

Reafirmación post-négritude: Globalización cultural........................................................... 35

Capítulo 2

La transculturación y la négritude: contrapunteo racial-transcultural ..................................39

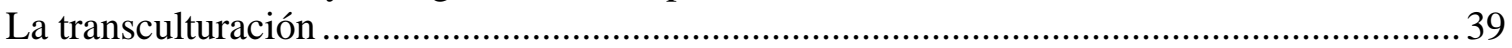

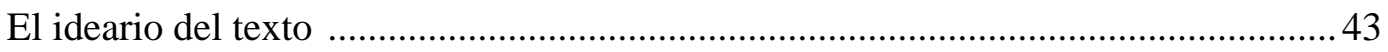

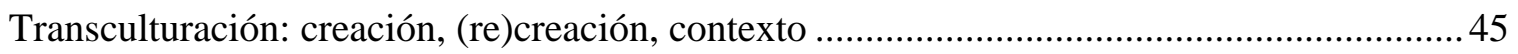

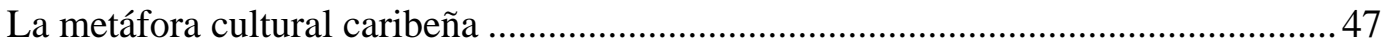

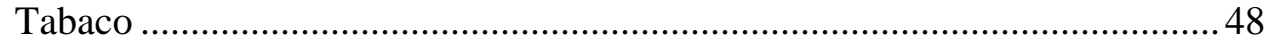

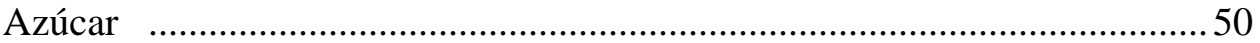

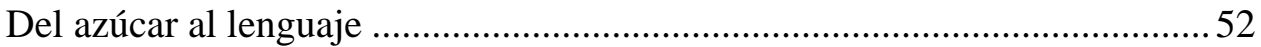

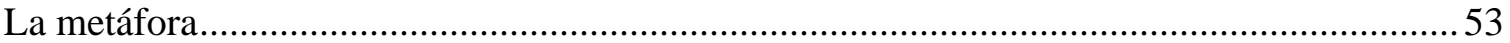

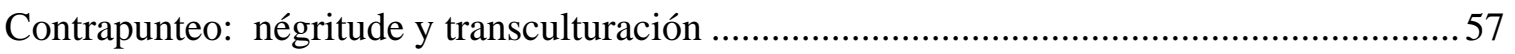

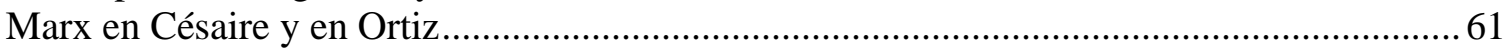

Capítulo 3

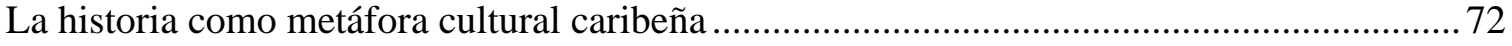

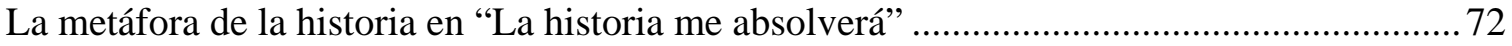

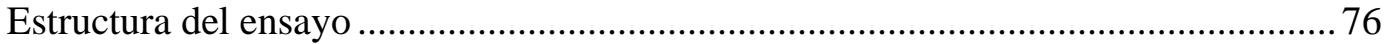

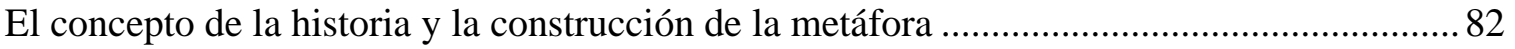

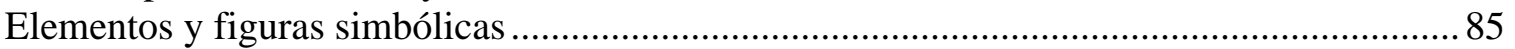

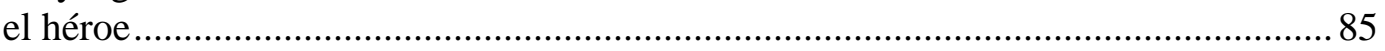

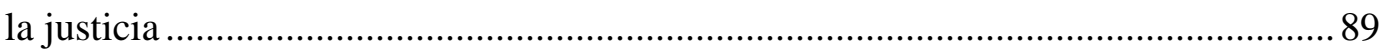

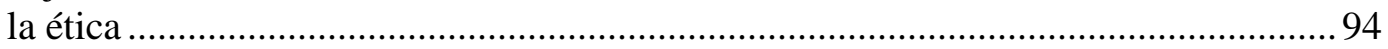

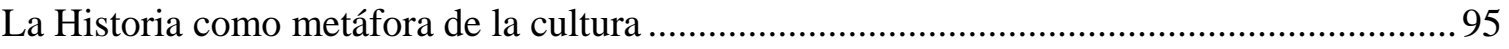

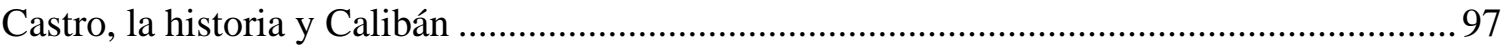




\section{Capítulo 4}

Las metáforas de la criollización/creolization y la síntesis espiritual-cultural:

integración y desintegración

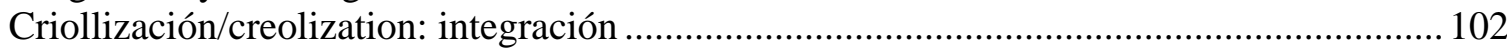

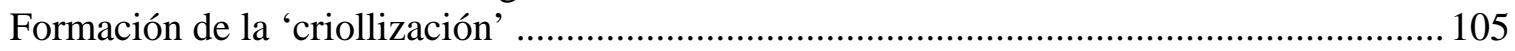

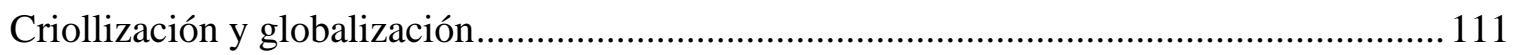

La realidad-ficción y la expresión espiritual: enajenación y desintegración.......................... 113

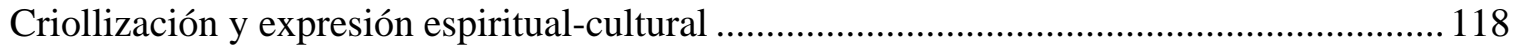

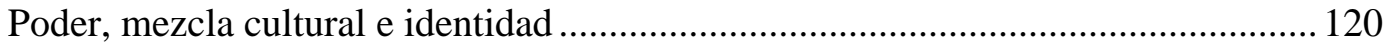

Capítulo 5

Antillanité y créolité: el lenguaje créole como símbolo cultural caribeño ............................125

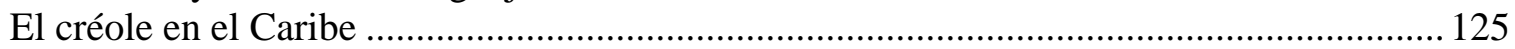

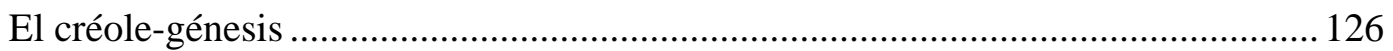

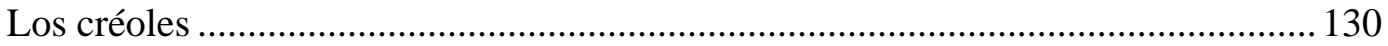

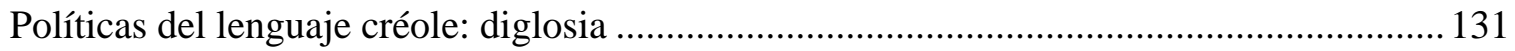

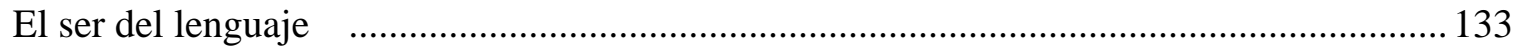

Le Discourse Antillais: la cultura a través del lenguaje en el Caribe ................................... 137

El créole: lo reformado, lo múltiple y lo total .................................................................. 141

Capítulo 6

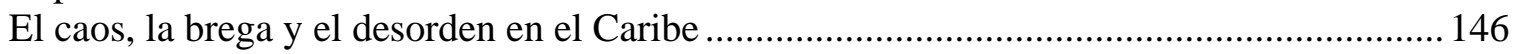

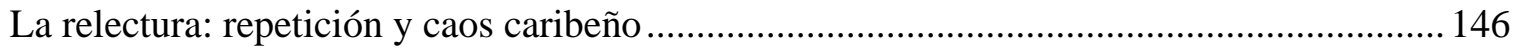

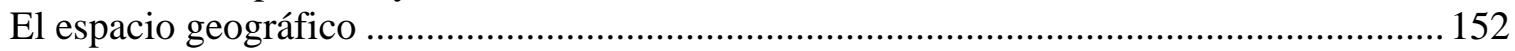

El espacio insular caribeño como no-violento: Pedreira y Benítez Rojo.................... 154

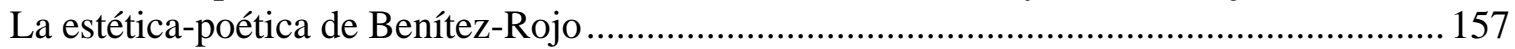

La brega: metáfora de la estrategia y la negociación en la cultura del Caribe ...................... 159

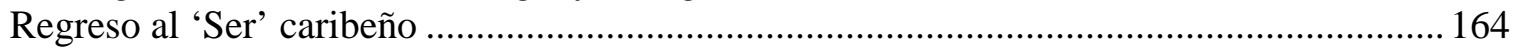

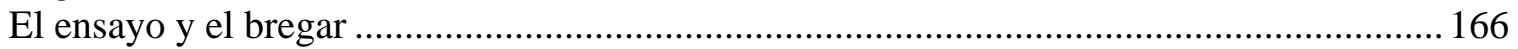

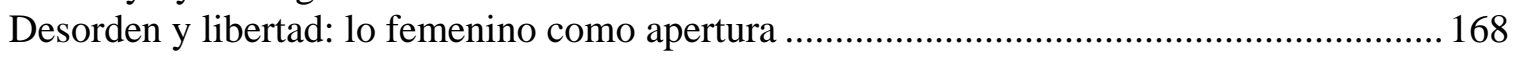

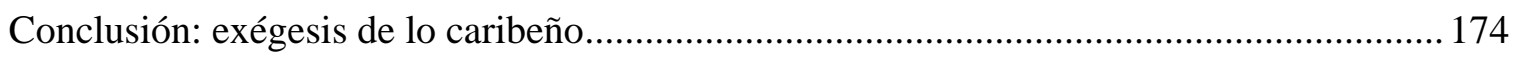

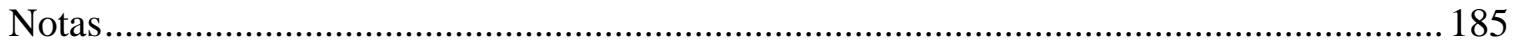

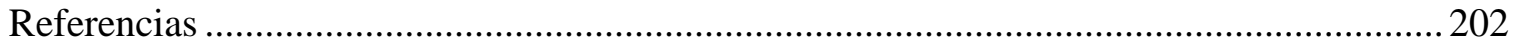

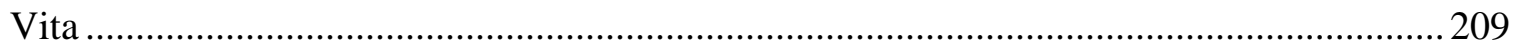




\section{Introducción: (Re)leer el Caribe y su cultura}

\section{Exposición del tema}

El presente trabajo abstrae modelos epistemológicos analizando propuestas teóricas culturales en el ensayo del siglo $\mathrm{XX}^{1}$ en el Caribe, integrando sus principales vertientes lingüísticas: hispanohablante, angloparlante y francófona. Todos los capítulos giran alrededor de las teorías de identidad caribeña señaladas como metáforas culturales, con la intención de mostrar cómo la metáfora trasvasa lo literario y revierte lo 'real' cultural. La tesis central es demostrar que las propuestas o teorías de estos ensayos son representaciones metafóricas de la cultura en el Caribe. El análisis de estos textos lleva a señalar la cultura, considerada desde la óptica de los autores aquí estudiados, como una metáfora que representa la 'realidad' del ser humano en la sociedad; reconoce elementos que manifiestan y que son parte de la diversidad dentro de la unidad del Caribe.

Para ejemplificar la propuesta se examinan los siguientes ensayos caribeños y sus modelos epistemológicos correspondientes. El primer capítulo estudia la creación del término “négritude” según lo concibe Aimé Césaire (1913-2008), uno de sus creadores principales, que aparece de forma inicial en la revista académica estudiantil L'etudiant noir en el artículo “Négrerie: Jeunesse noir et assimilation” (1934). El segundo capítulo analiza el término “transculturación” de Fernando Ortiz en el libro Contrapunteo cubano del tabaco y el azúcar (1940). Al mismo tiempo, el análisis establece paralelos entre estos autores, pues, ambos crean metáforas raciales para definir la cultura caribeña. El tercer capítulo está configurado en torno al ensayo de Fidel Castro, “La historia me absolverá” (1953), visto desde una mirada a los tropos que conforman la construcción de la historia como metáfora cultural del Caribe. Se adaptan además las ideas que desarrolla el barbadense George Lamming en "The Pleasures of Exile” (1960) acerca de la figura de Calibán. Elementos como lo heroico 
funcionan entonces para entrelazar el símbolo que representa Calibán, junto con la historia y Castro; así también junto con lo mítico que moldea y, eventualmente, fragua una lucha por la libertad. En este apartado se considera el marco histórico y teórico de la pre-Revolución cubana en tanto modelo crítico de la cultura poscolonial caribeña.

A partir de mediados de la década del sesenta las propuestas cambian su enfoque, antes racial e histórico, a uno más teórico y lingüístico. El análisis del cuarto capítulo parte de varios ensayos de Kamau Brathwaite en los que examina el concepto de creolization, específicamente, en The Development of Creole Society in Jamaica 1770-1820 (1970), “Contradictory Omens: Cultural Diversity and Integration in the Caribbean” (1973) y “Caribbean Man in Space and Time” (1974). En estos escritos el autor hace un análisis histórico, económico y político de la sociedad jamaiquina y caribeña. Puntualiza así la imagen de su cultura considerando la integración de los elementos híbridos que funcionan en la metáfora caribeña. En este mismo apartado se observa la propuesta que hace sobre "la expresión espiritual” dominicano-caribeña, Juan Isidro Jiménes-Grullón en La República Dominicana: una ficción (1965). Este texto complementa la metáfora de la criollización, no obstante, a partir de la representación de la desintegración social en la cultura del Caribe.

En las dos últimas décadas del siglo XX, los autores optan por una conciencia plural del Caribe. Primero, en la penúltima década interesan algunos ensayos que observan esa pluralidad a partir del idioma créole. Por lo que es imprescindible comenzar con un ensayo que estudia la función de este idioma en el contexto de las políticas de la lengua oficial en las islas. Se trata de una investigación que hace Hubert Devonish en Language and Liberation (1986) sobre el carácter diglósico que tienen las sociedades caribeñas de habla créole. En particular propone que esto simboliza las dinámicas en la sociedad y la cultura del espacio antillano. Por eso también se condensa brevemente en este capítulo un sumario de varios 
estudios acerca de la génesis del créole y las teorías desarrolladas a su alrededor. Se consideran consecuentemente otros ensayos de Edouard Glissant, publicados en Le discours antillais (1981). Para el martiniqués, el créole representa igualmente la cultura caribeña, sin embargo, su valor metafórico recae en su relación inevitable e inconsciente con el idioma de la metrópolis. Igualmente, aquí se analiza la metáfora de la creolité, ideada por Patrick Chamoiseau, Rafael Confiant y Jean Bernabé en Éloge de la Creolité (1989). Estos ensayistas tienen una aproximación a la lengua créole vista como modo de (re)apropiación del lenguaje (la expresión) y, por ende, de su identidad.

La isla que se repite (1989) de Antonio Benítez Rojo introduce el análisis del sexto y último capítulo. La década ulterior del siglo XX manifiesta la creación de metáforas postmodernas que se basan en la multiplicidad cultural del Caribe. Benítez Rojo compara las dinámicas y movimientos de la cultura caribeña con las disposiciones de la teoría del caos. Éste explica cómo incluso en la composición geográfica de las Antillas se determinan las formas culturales. Semejante al acercamiento que se hace del trabajo ensayístico de este académico y novelista cubano, se aborda igual el ensayo “De cómo y cuándo bregar” (1999), publicado posteriormente en el libro El arte de bregar (2003), del puertorriqueño Arcadio Díaz Quiñones. Tanto Benítez-Rojo como Díaz-Quiñones presentan una mirada abarcadora de la cultura que permite ver el Caribe desde sus imprecisiones, afirmaciones y negaciones. El cierre de mi trabajo apunta al ensayo de Maryse Condé, “Order, Disorder, Freedom, and the West Indian Writer” (2000). Sirve este último para ilustrar la metáfora del desorden, la misma que representa la libertad de la consciencia creativa cultural en el Caribe. La autora guadalupeña advierte cómo el rol de las escritoras femeninas y de la juventud es necesario para evitar la imposición de un orden fijo. 
A lo largo de este proyecto y en determinados tópicos se corrobora que los ensayos examinados tienen un carácter multiperspectivo afín con la nueva conciencia emergente de la globalización cultural que caracteriza el siglo estudiado. Sin embargo, aunque siempre las civilizaciones han 'evolucionado' a raíz de los encuentros de unas sociedades con otras, la accesibilidad que comienza en el siglo XX permite que estos intercambios culturales se den con mayor facilidad. ${ }^{2}$ Precisamente, el archipiélago del Caribe constituye un espacio idóneo para representar esta diversidad cultural que proyecta la multitud de puntos de vista de la actualidad global.

Las conclusiones de este trabajo comprueban la viabilidad que tiene el género ensayo para la creación de metáforas, además de apuntar a representaciones plausibles de la cultura y de la sociedad que la crea. Con esto y a través del análisis crítico de los distintos autores, el vehículo de la metáfora permite asimismo plantear modelos epistemológicos culturales con los que conceptuar la posibilidad de una ideología transcaribeña.

\section{Marco teórico y acercamiento crítico}

La dinámica de estas propuestas que componen representaciones metafóricas de la cultura pancaribeña concuerda con lo que Jorge Luis Borges (1899-1986) señala sobre la realidad absoluta. Borges advierte que ésta no es cognoscible por el hombre, contrario a la cultura que al ser un fenómeno creado por él puede ser conocida o al menos representada. Por consiguiente, el autor entiende las realidades culturales por mediación de modelos conceptuales o metáforas epistemológicas. Dice Borges:

No existe una esencial desemejanza entre la metáfora y lo que los profesionales de la ciencia nombran la explicación de un fenómeno. Ambas son una vinculación tramada entre dos cosas distintas, a una de las cuales se 
la trasiega en la otra. Ambas son igualmente verdaderas o falsas. ("La metáfora” 114; mi énfasis)

Aquí el poder de la metáfora o del tropo recae en la capacidad de describir y comparar dos fenómenos no relacionados (o de relación imperceptible o parcial). La metáfora tiene base en la realidad o se obtiene mediante construcciones simbólicas. El acto de identificación de dos conceptos que difieren y que a la vez se relacionan, dadas las "subrayaduras parcialísimas del sujeto”, explica y crea enlaces causales con el propósito de tratar hechos del mundo en que vivimos (“La metáfora” Borges 114-5). De modo que para conocer el mundo en el que se vive se hace estableciendo vínculos para complementar el sentido y así entender; porque si se dice que 'entendemos' se quiere decir que se ha encontrado una relación o un conjunto de relaciones satisfactorias entre el mundo ficticio y el real (Scholes \& Kellogg 82). La metáfora media en la comprensión de lo propio y del entorno.

Otro marco teórico esencial para este trabajo son las ideas sobre la narración histórica, concebida a través de metáforas, según Hayden White en su libro Tropics of Discourse (1978). El autor señala que la metáfora sirve de guía a través de series de imágenes que llevan a asociar y analizar según la experiencia, la realidad de cada cual:

The metaphor does not image the thing it seeks to characterize: it gives directions for finding the set of images that are intended to be associated with that thing. It functions as a symbol, rather than a sign: ... [it] tells us what images to look for in our culturally encoded experience in order to determine how we should feel about the thing represented. (91; mi énfasis)

Para White, la metáfora funciona como una imagen que depende de cada código vivencial cultural de cada creador/lector que la enfrenta. Esto quiere decir que los autores que crean las diferentes metáforas o modelos epistemológicos apelan a distintos signos culturalmente 
reconocidos para transmitir varias significaciones que ulteriormente representan su idea principal. White añade que la metáfora apunta lo que se ha de observar para así descodificarlo por medio de nuestra experiencia cultural, tomando en cuenta que hay dos niveles de descodificación, el del autor del ensayo y luego el que el lector adquiere de la interpretación metafórica del primero. De ahí que las representaciones epistemológicas que este trabajo analiza partan de esa misma experiencia cultural que dota de significado a esos modelos metafóricos que a su vez posibilitan conceptualmente esa 'realidad':

La metáfora, en términos de enunciado, se convierte en portadora de sentido, facilitando una interacción válida entre los diferentes planos del discurso. La interpretación de las metáforas permite la construcción de modelos que pueden representar, conceptual y adecuadamente, una estructura teórica como imagen de lo real en los textos. (Cavallín-Calanche; mi énfasis)

Por otro lado también el concepto de la realidad es estudiado desde el punto de vista de Karl Jaspers (1883-1969), quien dice que el hombre es fuente de la creación de lo real. Éste señala que, "Everything depends therefore on encountering thought at its source. Such thought is the reality of man's being, which achieved consciousness and understanding of itself through it” (Jaspers 71). Entonces, enfrentar la fuente misma del pensamiento, según Jaspers, es confrontar la realidad del ser del hombre ya que éste adquiere conciencia y entendimiento de sí a través de sí. Precisamente y de acuerdo con Borges, la comprensión y toma de conciencia de la realidad yace en el hombre mismo y su pensamiento, el cual depende estrictamente de las conexiones que surgen de los distintos elementos de las realidades subrayadas por los diferentes individuos. Con esto surgen las metáforas que ulteriormente ayudan a la compresión de los fenómenos humanos de acuerdo con las distintas percepciones que existen. 
De forma similar, la idea de entender la cultura como metáfora, específicamente en los pueblos colonizados, la analiza Homi K. Bhabha en The location of culture (1994), donde señala, entre otras cosas, cómo puede relacionarse lo cultural con los elementos raciales. En efecto, Bhabha habla de la metáfora que surge como resultado de la relación con el coloniaje: “...the metaphor [...] is complicit with a Western metaphysic of Man that emerges from the displacement of colonial relationships” (60). Por supuesto, esta perspectiva no se centra solamente en el Caribe sino que se refiere a la situación de todos aquellos espacios colonizados. Además, en las metáforas caribeñas puntualizadas en la presente investigación habría que reconocer por separado si son subversivas o contrariamente sub-sirven al coloniaje. Esto es, surge en este sistema “ [a] dialectic of mind/body... found within the epistemologies of appearance and reality” (60). Nuevamente, la relación con la metáfora frente a la apariencia y la realidad depende de la mirada del ser humano, de su filosofía que, en este caso y como señala Bhabha, surge por el desplazamiento de las relaciones colonialeshistóricas que dan paso a otros fenómenos sociales-humanos que viabilizan las construcciones metafóricas.

En este orden de ideas los autores estudiados en este trabajo proveen la visión de sus culturas a partir de las inevitables relaciones que emergen de la colonización en el Caribe. Este evento histórico en común hace que los desplazamientos y procesos sociales permitan construcciones metafóricas de la cultura caribeña que, en sus diversidades, apuntan a cierta unidad. Al respecto, Bhabha explica que la existencia de una dialéctica entre la mente y el cuerpo se da entre lo que es aparente y lo que es real, y que se define y cuestiona a través de la imagen de la identidad. El autor resuelve la correspondencia entre mente-cuerpo en la epistemología de la relación entre la apariencia y la realidad. Para esta investigación, esa epistemología coincide con la metáfora borgiana pues, como se ha dicho, es una alusión 
“parcialísima” de una representación cultural que toma significado en el Caribe al hacer un desplazamiento de lo hegemónico europeo frente a la periferia colonizada de AméricaCaribe.

\section{Contexto crítico}

La construcción de un modelo caribeño es una contribución a la epistemología cultural en general, ya que estos principios pueden ser de utilidad en otras regiones y espacios culturales en el contexto de la globalización. El término de epistemologías caribeñas utilizado aquí se refiere a teorías del conocimiento cultural que consideran la naturaleza, la escala y las fuentes de ese conocimiento, con el propósito de demarcar y definir la posibilidad de una cultura coherente pan-caribeña a través de los aspectos raciales, históricos, lingüísticos y geográficos.

Ciertamente, la sociedad y la academia han definido la globalización en varios ámbitos, sobre todo en el carácter económico y político que este término supone. No obstante, el concepto de globalización cultural usado aquí remite a "la experiencia cultural de poblaciones físicas e históricamente distantes en marcos comunes”, que según Arturo Ramos Pérez trata de una 'cultura global’ que alude, entre otras formas, a “...los símbolos y significados que sostienen identidades colectivas fundamentales, como son el lenguaje, el imaginario o las experiencias vivenciales restringidas” (87). Ramos Pérez señala también que esto es posible no sólo por el desarrollo tecnológico sino por el "efecto generalizador que la globalización económica lleva hacia todas las esferas de la vida social” (87). La cultura global resulta en "nuevos procesos de constitución de identidades sociales y de formas de asumir la experiencia cultural por los individuos y las colectividades” (88). De forma específica, John Tomlinson en Globalization and Culture (1999) plantea que la globalización es multidimensional y que esas dimensiones están interconectadas (discurso económico, 
político, cultural, etc.), por lo que es imposible enfocarse en solo una. Tomlinson explica que la cultura trata de un orden de la vida en el que el ser humano construye significados: "culture can be understood as the order of life in which human beings construct meaning through practices of symbolic representation $[\ldots]$....in which people make their lives, individually and collectively, meaningful...” (18). Tanto Ramos Pérez como Tomlinson reconocen las distintas perspectivas que ocupa el término globalización y apuntan sus análisis a esas construcciones que crea el ser humano para darle significación a los diferentes aspectos de la vida, es decir, la cultura.

De esta forma lo global y lo cultural demarcan los ejes para esta investigación. Lo cultural es una construcción que representa simbólicamente las prácticas de los seres humanos, tal y como Borges lo plantea, y lo global señala las particularidades que surgen en

distintos espacios y contextos. Ahora bien, el fenómeno de la globalización cultural implica una constante negociación de los elementos que constituyen los espacios geográficos así como de los saberes, patrones sociales y creencias de los sujetos:

...it affects people's sense of identity, the experience of place, of the self in relation to place, how it impacts on the shared understandings, values, desires, myths, hopes and fears that have developed around locally situated life. (Tomlinson 20)

Por esto este trabajo examina las distintas propuestas de identidad caribeña conforme a la globalización cultural; éstas sirven de marco referencial que posibilita estudios futuros de otras culturas y la construcción de nuevas metáforas.

\section{Las definiciones, El Caribe}

Para precisar las propuestas en los textos aquí estudiados, es crucial observar la definición que algunos críticos han dado del Caribe. En este sentido, resulta útil la 
denominación que Iris Zavala utiliza para describir el archipiélago caribeño: “an irreducible surplus of signification that manages to remain heterogeneous” (127). Esta interpretación concuerda con la definición de algunos de los pensadores caribeños incluidos en este trabajo. Por ejemplo, Antonio Benítez-Rojo interpreta el Caribe como "un número de naciones americanas con experiencias coloniales distintas, que hablan lenguas distintas, pero que son agrupadas bajo una misma denominación” (19; mi énfasis). Asimismo, Gordon Lewis define así el Caribe en Main currents in Caribbean Thought (1983):

...despite the contrasts between one island-society and another -and despite the different identifying names that region has acquired throughout its momentous history (The Spanish Main, the West Indies, the Antilles, the Caribbean)- the area is characterized by a distinctive communality of leading features that justify the concept of a collective sociocultural character, setting it apart from its neighbors. (3; mi énfasis)

Las tres elucidaciones son muestra de algunas de las tantas definiciones del Caribe que se han propuesto a lo largo del siglo XX. Coinciden con la idea que "[the] Caribbean is neither a biological or transhistorical fact but a contingent discursive construction” (Zavala 128; mi énfasis). El Caribe como construcción discursiva contiene y exige un proceso de análisis, un discurso, un razonamiento que busca una forma apropiada para su representación.

Ahora bien, el Caribe contiene pluralidad de espacios que son simultáneamente uno. Éste contiene a su vez otros espacios que en su pluralidad y singularidad, a través de procesos étnico-raciales, históricos, políticos, religiosos, sociológicos, económicos, lingüísticos y geográficos, entre otros, comparten entre sí gran producción literaria ensayística. Partiendo de su geografía fragmentada, su segregada historia colonial y su diversidad racial y lingüística, los intelectuales caribeños han establecido puentes de unidad cultural con la 
intención de configurar esta identidad pan-caribeña. En este proceso los autores afrontan la realidad de no poder crear un modelo cultural único y exhaustivo del archipiélago, pues aunque los procesos de examinación crítica logran redefinir algunos aspectos culturales importantes, usualmente resultan en una visión parcial del conjunto caribeño. Asimismo, éstos examinan críticamente los componentes que forman sus identidades regionales en contraste con los elementos culturales que tradicionalmente habían sido impuestos por el discurso colonial de la metrópolis.

\section{Género literario: el ensayo}

No es extraño que estos pensadores coincidan en la utilización del ensayo para articular sus teorías. Efectivamente, este género literario resulta un vehículo primordial para las expresiones ideológicas de sus autores considerando los comienzos y usos que ha tenido. El ensayo lo denomina Michel de Montaigne en 1580, aunque ya lo usan autores en la civilización occidental, siglos antes, como por ejemplo Platón en los Diálogos, Cicerón, Horacio y Séneca en las Epístolas, Plutarco en las Vidas paralelas, Aulo Gelio en las Noches áticas, San Agustín en las Confesiones, entre otros. Igual y poco después de Montaigne, en 1597, Fracis Bacon también utiliza este género. Ambos son figuras centrales para el desarrollo que adquiere en la literatura moderna:

En Montaigne, en fin, domina la intuición 'poética', en Bacon la 'retórica'. Así, desde sus comienzos, Montaigne y Bacon representan dos opuestas posibilidades de ensayo, que profetizan el futuro individualista del género: El ser de Montaigne está en sus ensayos, tanto como el de Bacon en los suyos. Unos y otros son exponentes de sus personalidades y preocupaciones. (Gómez-Martínez; énfasis mío) 
Entrambos, con el ensayo comienza a expresarse explícitamente el "Yo" del autor en la obra literaria. Esto hace que el ensayo mismo sea subjetivo ya que manifiesta la individualidad del ensayista; sin olvidar que de todas maneras, según Benedetto Croce, todo trabajo literario resulta único e irrepetible (Cruz Delgado 15).

Esta subjetividad del género tiene relación con la visión de la realidad de Borges pues concuerda con la creación de propuestas metafóricas que representan las variadas realidades de los seres humanos que las producen. Es decir, la heterogeneidad innata de los autores es igual a la naturaleza de los ensayos y sus temas. Cada análisis presenta la voluntad del ensayista revelando un proceso dialógico en el que el lector está incluido como parte integral de éste a través de las sugerencias de cada autor (Gómez-Martínez). ${ }^{3}$ El ensayo caribeño del siglo XX y de comienzos del siglo XXI provee la oportunidad de enlazar al escritor con el lector en una relación dinámica y metafórica que, como tal, puede resultar en diversas interpretaciones. Interesantemente, en contraste con el ensayo, el tratado pretende ser objetivo y científico, no obstante, igualmente apela a la mediación metafórica para representar la realidad (Borges). Por esa falsa objetividad precisamente, y por su filiación (pseudocientífica) con el discurso de la metrópolis, no es considerado por los escritores caribeños que se inclinan en favor del ensayo literario, llanamente metafórico. El ensayo en fin da la oportunidad de proyectar la identidad del autor y la de su propia cultura.

Esto puede observarse mejor en la formación del pensamiento latinoamericano y de las luchas de independencia de estos países, en la que el ensayo juega un rol fundamental dado a que se utiliza con gran conciencia literaria, política y cultural. Con las ideas filosóficas que vinieron de Europa, "la gesta independentista en América Latina, [y luego] los gobiernos nacientes[,] vieron [sobre todo] en el positivismo un sistema idóneo para implantar una estructura política, económica y social” (Cruz-Delgado 60). ${ }^{4}$ Luego, a finales del siglo XIX 
algunos autores crean nuevas pautas para la modernidad en el género literario del ensayo. ${ }^{5}$ En los textos creados en América latina la ordenación del entorno social fue, entre otros, uno de los temas culturales más tratados.

De acuerdo con esto, entonces el ensayo es un género apropiado para expresar y proveer modelos culturales que se corresponden con los distintos aspectos del Caribe. Las teorías culturales caribeñas del siglo XX de cierto modo reescriben ideas del siglo anterior, que son reacciones a previos discursos hegemónicos en reflejo de los cambios sociopolíticos que se suscitan de las guerras de independencia latinoamericana.

\section{Antecedentes literarios}

El ensayo es asimismo adecuado para promover cambios en los ejes de poder. Algunos de los antecedentes más influyentes en el Caribe son las ideas expuestas en la Federación antillana (1867-98) de Ramón Emeterio Betances (1827-1898) y Eugenio María de Hostos (1839-1903). Estos puertorriqueños establecen su interés por la Federación, aunque cada uno a su modo. De acuerdo con Carlos Rama, Betances prevé que “Todos y cada uno de los pueblos antillanos fueron concebidos como parte de la Federación Antillana que pensó, por lo menos desde 1867”. Para Betances la unidad política del Caribe es necesaria para lograr la independencia. Similarmente, en La peregrinación de Bayoán (1863) de Hostos, resalta la idea de un proyecto cultural antillano: "Pero si mi patria política era la Isla infortunada en que nací, mi patria geográfica estaba en todas las Antillas, sus hermanas ante la geología y la desgracia, ya estaba también la libertad, su redentora” (Hostos 71). Hostos plantea sus concepciones filosóficas e ideológicas a través de la literatura. Aunque se trata de una narración novelada, Hostos aprovecha el texto para "la fusión de dos funciones diferenciadas" en la que está "la del ensayo que es conceptual y argumentativa,..." (Cruz Delgado 71). ${ }^{6}$ Ambos caribeños comienzan a distinguir la unidad de los antillanos como una 
meta política y con esto reconocen que esa unión es necesaria para crear fuerzas con la intención de reconstruir su realidad, legado del régimen colonial europeo.

Del mismo modo, “Nuestra América” (1891) de José Martí (1853-1895) forma parte de esos ensayos fundacionales que promueven las ideas del siglo XX en el Caribe. En este famoso texto Martí expone la oposición entre la falsa erudición y la naturaleza, en el contexto de las circunstancias de América latina y el Caribe. El autor aconseja que para crear una identidad americana apropiada es necesario reformar y reestructurar la visión intelectual del continente, “to delineate it anew” (Del Real 200): “...[por]que la salvación está en crear” (Martí). El autor busca una dialéctica entre el hombre y la naturaleza (Rojas Osorio) y utiliza el entorno del continente americano para señalar ejemplos de lo autóctono y así crear imágenes metafóricas de nuevas formas que posibilitan la reconstrucción de la identidad americana. Martí busca crear fundamentos para la lucha en contra del sistema colonial que aún prevalece en el Caribe a finales del siglo XIX; y así también intenta combatir la posible amenaza de un nuevo imperio, "el gigante de siete leguas” que quiere extenderse en la región. $^{7}$

Estos pensadores emprenden la idea de reconstruir la identidad del Caribe a través de la concepción de la percibida unidad entre las islas. Los tres promueven la lucha en favor de la independencia mediante la resistencia, armada e ideológica. ${ }^{8}$ Estos autores exigen desmembrar la situación suscitada con el estado colonial; “En extrema oposición a esta civilización traída de tierras ajenas, Hostos, [Betances,] como más tarde haría Martí, propone[n] una búsqueda de la identidad dentro del entorno propio” (Cruz-Delgado 70). Los tres siguen los ejemplos de los pensadores latinoamericanos que, en sus esfuerzos por alcanzar la independencia de sus países desde 1810, usan el ensayo como valioso instrumento 
en el que configuran "las líneas del organismo histórico, cultural y social de nuestros pueblos” (Cruz-Delgado 72).

\section{Organización y enfoque por capítulo}

Cedomil Goic (1928), reconocido historiador y crítico literario, utiliza el método generacional de quince años en su estudio historiográfico de la literatura hispanoamericana. Para el académico las generaciones son las que forman las concepciones generales de la literatura y su avance a través del tiempo histórico. Conforme al criterio de esta periodización, se dispone la división de los capítulos del presente trabajo. En particular, de acuerdo a Goic, sucede que esta cantidad de años permite abordar un sentido total de los elementos fundamentales que constituyen los criterios que definen dicho periodo. Por lo tanto aquí se considera factible utilizar esta metodología.

Con el fin de precisar esta investigación hay que señalar que desde el primer cuarto del siglo XX los pensadores caribeños continúan los cuestionamientos y debates anteriores. Sus obras discurren sobre el sistema colonial, los procesos étnicos, las formaciones lingüísticas y también conceptos de hibridez, sincretismo, transculturación y heterogeneidad. Así, los primeros dos capítulos de este trabajo, “La metáfora racial de lo caribeño: la négritude” y "La transculturación y la négritude: contrapunteo racial-transcultural”, estudian el periodo entre 1930 y 1945. Este segmento reúne los primeros modelos teóricos que predominantemente tratan aspectos raciales en el Caribe. Las metáforas en torno a las cuales gira el análisis de los capítulos son négritude y transculturación de Césaire y Ortiz, correspondientemente.

El siguiente apartado, el capítulo tercero, comprende el marco temporal desde 1945 hasta 1960. El modelo dominante en este periodo configura ensayos que tratan eventos y figuras históricas que inevitablemente se relacionan con el sistema colonial y sus consecuencias. Los 
tropos abstraídos en el capítulo “La historia como metáfora cultural caribeña” apuntan a la historia como tropo epistemológico en los ensayos de Castro y Lamming.

El cuarto capítulo presenta un análisis de la perspectiva multidisciplinaria del concepto de criollización de Brathwaite. En "Las metáforas de la criollización/creolization y la síntesis espiritual-cultural: integración y desintegración”, se comprende el periodo entre 1960 y 1975; tiene su enfoque en las dinámicas sociales que surgen bajo el coloniaje. Otros modelos metafóricos de esta sección son la síntesis espiritual y la desintegración, ambos puntualizados por Jiménes-Grullón. De la criollización (integración) y la desintegración se pasa a un símbolo que ilustra incluso ambas denominaciones anteriores: el créole. Así, el siguiente apartado, “Antillanité y créolité: el lenguaje créole como símbolo cultural caribeño”, observa el créole como modelo epistemológico de la cultura del Caribe. Su génesis y continua (con)formación ilustran los movimientos y procesos por los que la cultura también pasa. Se observa la creación de este modelo cultural durante el periodo de 1975 a 1990. Este propone enlaces con la historia colonial y los procesos lingüísticos que suscitan en el espacio antillano.

El último capítulo analiza el periodo a partir de 1990 (específicamente 1989) hasta el fin del siglo. ${ }^{9}$ Las propuestas analizadas giran entorno a los modelos postmodernos del caos, la cierta manera (Benítez-Rojo), la brega (Díaz-Quiñones) y el desorden (Condé). Estos modelos pluriperspectivos se establecen con las relaciones que surgen entre los elementos sociales, estéticos, históricos, literarios, musicales, geográficos, cotidianos y más. Sus respectivas conexiones sirven para identificar la cultura caribeña. En "Lo plural, la metáfora, la relación y nuestro Caribe” se enfoca la diversidad dentro de la unidad del archipiélago. Concluyentemente, este proyecto responde a cómo los ensayos estudiados proponen patrones 
metafóricos y epistemológicos de la cultura del Caribe, constituyendo el primer estudio analítico y comparativo de algunos modelos claves. 


\section{Capítulo 1:}

\section{La metáfora racial de lo caribeño: la négritude}

"Buscarle ausencias al idioma es como buscar espacio en el cielo"

\section{La négritude}

(Borges, "Examen de metáforas” 72).

La creación y comienzo del uso del neologismo négritude surge durante el periodo de entreguerras del segundo cuarto del siglo XX en París. Aimé Césaire (1913-2008), junto a sus colegas Leopold Sédar Senghor (1906-2001) y Léon Gontran Damas (1912-1978), crean y desarrollan este movimiento denominado por muchos como literario y filosófico. Para Césaire, la finalidad inicial de la négritude es emprender la batalla de la juventud negra colonizada en contra de la asimilación (“Négreries” 3). Cada uno de estos promotores del concepto tiene visiones muy específicas y acordes con el contexto cultural del que provienen, así como de la experiencia que cada uno vive. Senghor y Damas concuerdan en que Césaire fue quien acuñó el término. Ambos indican que el poeta martiniqués escribe el vocablo négritude por primera vez en la revista académica L'étudiant noir en $1935 .{ }^{10}$ La aceptación o compromiso por parte de los tres fundadores que inician el movimiento surgido a partir de la noción de négritude, apunta a un carácter revolucionario de respuesta ideológica y política, mucho más que racial. Con el término, éstos acentúan variadas perspectivas y elementos según sus experiencias, pues, “Césaire, Damas and Senghor had individual lived experiences of their feeling of revolt against a world of racism and colonial domination” (Diagne 19).

Césaire indica que la négritude es un movimiento estético que apela a la unificación del negro y su reivindicación humana a través del arte. ${ }^{11}$ Asegura además que no se trata ni de una filosofía ni de una metafísica sino, más bien, de una manera de vivir la historia dentro de la historia, una historia singular de todas las experiencias de una comunidad: “C'est une manière de vivre l'histoire dans l'histoire: l'histoire d'une communauté dont l'expérience 
apparaît, à vrai dire, singulière...” (Césaire, “Négritude et Humanisme” 16-7). Con esto, se promueve una conciencia cultural negra en común que difiere de la de los blancos, franceseseuropeos (o bien americanos). De hecho, para el poeta la asimilación atenta en contra de la propia cultura negra, africana-antillana, y contra la de todos los que viven esa experiencia. Césaire y Damas, ambos provenientes de las colonias de América, recalcan la dimensión de una revuelta poética. Para Damas, igual que para Césaire, el concepto busca incluir a los negros a través de sus vivencias comunes bajo la dominación del colonialismo europeo. Damas ve la négritude como una fuerza poética vital en América que funciona para entender, identificar, expresar y revitalizar sus culturas, sus creencias y las formas de vivir del negro:

Le vent qui monte de l'Amérique noire aura vite fait, espère-t-il, de nettoyer nos Antilles des fruits avortés d'une culture caduque. Langston Hughes et Claude Mac-Kay, les deux poètes révolutionnaires, nous ont apporté, ... l'amour africain de la vie, la joie africaine de l'amour, le rêve africain de la mort. Et déjà de jeunes poètes haïtiens nous livrent des vers gonflés d’un futur dynamisme. (Damas 14-5)

Por otro lado, Senghor insiste en que el concepto tiene un propósito filosófico que resulta ser la suma de valores de las culturas negras. Para éste se trata de una ontología, una estética, una epistemología y una política (Diagne 4). En contraste con Damas y Césaire, Senghor percibe el movimiento como una búsqueda que rebasa la intención estética, artística o poética. Aunque, por la manera en la que el autor senegalés define el término, la crítica indica que marca solo una ideología neocolonialista y no una filosofía: "they accused Négritude of being, for that reason, an ideology for neocolonialism” (Diagne 7). Cabe señalar que Senghor lucha activamente hasta lograr la independencia de su país, en el que luego durante veinte años ejerce como presidente. ${ }^{12}$ 
Bajo el criterio de los tres "padres” del movimiento, el presente capítulo estudia los alcances de la négritude como metáfora cultural epistemológica. Con esto, es importante considerar la intención creadora del concepto y las posturas que toma la crítica al respecto. Pues, una manera de reconocer y afirmar la négritude como tropo es de acuerdo a las variadas lecturas y dinámicas que el término genera; así también la mirada sobre los eventos históricos y sociales, la situación nacional-cultural de la época, además del carácter multiperspectivo del negro.

En el actual estudio se toma en cuenta la base lingüística del concepto y, brevemente, algunas implicaciones de la creación de un neologismo. Según indica Juan Manuel García Platero en "Observaciones sobre el neologismo”, a propósito de las razones lingüísticas del surgimiento inicial de un vocablo, éste nace de "una necesidad por parte del emisor de comunicar unos hechos o cosas hasta el momento inéditas... [y, además, por] motivaciones basadas en la expresividad, [y no en una] necesidad 'real',... [que por lo tanto, encuentran] resistencia” (García Platero 49). ${ }^{13}$ Asimismo, un nuevo término aparece cuando hay una necesidad de expresar nuevas ideas en lugar de cosas. De ahí que la creación de Césaire produzca controversia y un sinnúmero de detractores en la crítica. No obstante, el discurso de Césaire presenta este “deseo de expresividad”, de búsqueda de estilo, primero, a través del género ensayo y, luego, llevado a su locución en distintas formas literarias como la poesía y el teatro.

Así, la existencia y uso de un neologismo advierten la admisión de ciertos parámetros dentro de un contexto dado. Por lo tanto, “debe aceptarse por la propia comunidad hablante para conseguir su pervivencia en el discurso” (García Platero 50). A más de 75 años de aparecer por primera vez el concepto de négritude, no hay duda que permanece en el discurso literario, filosófico-humanístico. García Platero añade que ${ }^{14}$ 
La supervivencia del neologismo como forma integrante del lenguaje sólo encuentra justificación en una dimensión histórica, dentro de la sustancia del tiempo. Éste es un primer criterio para su identificación, puesto que es el tiempo quien puede dar al vocabulario su independencia y su autonomía, tanto semántica como formal y funcional, características ambas que vienen dadas por la frecuencia de uso del vocablo o giro en cuestión, y que en último término reciben... su entrada en el diccionario. (García-Platero 50; mi énfasis)

La “justificación en una dimensión histórica”, antes aludida, interesa en cuanto a la consideración que Hayden White provee sobre la interpretación histórica como una representación plausible del mundo (58). Esto supone que la négritude como neologismo se define y forma a través de su perpetuación histórico-temporal y del uso colectivo del mismo. La independencia y autonomía que adquiere el término estriba en las diferentes aseveraciones que recibe, no solo por la intención del emisor-creador sino también por la acogida del receptor-comunidad.

El título del ensayo que aquí se estudia, “Négreries: jeunesse noir et assimilation”, alude directamente al colonialismo. El concepto nègrerie establece una correspondencia con el uso que la palabra solía tener en la época de la esclavitud que significaba, "local où étaient enfermés les esclaves noirs”. ${ }^{15}$ Con esto, la intención de Césaire está íntimamente ligada con la situación del vasallaje, puesto que, como evento histórico común, marca y encierra no solo al negro sino a todos los que viven bajo el sistema de la colonización.

Por otra parte, algunos detractores advierten que nègre, en las décadas del veinte y el treinta, alude a una representación despectiva del negro. Por esto, este vocablo contiene una fuerza "revolucionaria” que se rebela en contra de la negatividad que connota nègre. De ahí que la noción de négritude tenga un carácter polémico:

The polemical intent of the usage is clear when one considers the profoundly pejorative meanings attached to the Word nègre in French -synonymous with 
slave for much of colonial history- particularly in the early twentieth century French Caribbean where the more educated blacks defined themselves as noir and reserved the term nègre for lower class blacks or uncivilized Africans. $(\text { Garraway 73) })^{16}$

Precisamente, la alusión peyorativa de nègre establece entonces paralelismos con los estragos de la esclavitud implícitos en el sistema colonialista. Con esto, négritude marca un proceso inicial para cambiar la perspectiva negativa que el negro tiene de sí mismo (disposición que el régimen había implantado).

Los estudios críticos que siguen a la creación del término négritude son extensos y proveen un sinnúmero de perspectivas tanto a favor como en contra del mismo. Este trabajo considera las ópticas más significativas y pertinentes para el análisis del concepto como metáfora cultural caribeña.

En primer lugar, Wole Soyinka (1976) indica que reprueba el vocablo césairiano porque apunta a una base centrada románticamente en la esencia de la raza. La importancia que tiene la crítica de Soyinka es que su trabajo influye en los estudios postcoloniales (Garraway 74). ${ }^{17}$ Además, inicialmente éste da a conocerse como crítico fiero en contra del término, declarando que un tigre no pregona su tigritud sino que actúa. ${ }^{18}$ Más tarde, Soyinka añade que no está en contra de la noción de Césaire como herramienta de búsqueda de la identidad del negro, sino que con lo que no concuerda es que ésta sea reconocida como parte de una discusión ideológica. Ulteriormente, Soyinka acepta que de joven toma posiciones muy extremas en su crítica:

[...] I have conceded some of the extreme over reactions to négritude. It wasn't that we ever objected to négritude, per se, no. We believe very much in certain unique characteristics of different peoples. I believe very much in the plurality of cultures, [...] ...about globalization of the economy, globalization of the culture... I hope it does not mean the end of variety in 
cultures... It's a very distinct kind of black, African, synthesis of cultural approaches, which you can describe as négritude. What we did not want at that time was a romantic celebration of that essence. It was the theorizing, which objected. (Bird Communication, Lille 1996)

Un segundo enfoque a la crítica es el que trata la noción de la négritude como una estética mística-ideológica racial. Georges R. Coulthard indica, en "Négritude -Reality and Mystification”, citando a Jahnheinz Jahn, ${ }^{19}$ que el origen del concepto no es el surrealismo como otros estudiosos afirman, ya que, "The great difference is that surrealist art, or art influenced by surrealism, does not base its style and attitudes on a racial mystique” (Coulthard 46). Tanto para Jahn como para Coulthard, el vocablo de Césaire proviene de la herencia religiosa africana (Muntú), que llega a América a través de los dogmas y costumbres de los negros (Coulthard 45). Por otro lado, Coulthard alude a otro crítico, Rachid, indicando en "Négritud, monería y mistificación” ${ }^{20}$ que, "la negritud como experiencia metafísica ha constituido el primer movimiento de toma de conciencia del hombre negro como negro primeramente, es decir en su profunda singularidad” (Coulthard 210).

Otro grupo de detractores señala la intención de Césaire como incongruente. Varios críticos y escritores caribeños tildan el movimiento de la négritude de favorecer la visión del colonizador. Entre éstos están Franz Fanon, Maryse Condé, C.L.R. James y otros. Fanon, aunque acusa varias veces a Césaire, al mismo tiempo, concluye apoyando el primordial propósito de desenmascarar una realidad colonial que asimila al negro; ese negro que se hace blanco (la máscara) para poder participar de la “civilización” que surge a partir de los eventos del colonialismo (Coulthard). Igualmente, Condé indica que Césaire es ambiguo (lo mismo dice de Edouard Glissant), ya que su trabajo muestra “...the confusion between political and poetic ambitions...” (157). ${ }^{21}$ Para Condé, el problema estriba en que, a pesar que Césaire, el poeta, clama por la lucha en contra del colonialismo y la asimilación, ulteriormente, Césaire, 
el político, desemboca en respuestas que contradicen lo que el poeta pretendía. A esto se le añade el reclamo que hace James sobre la defensa de la identidad del negro: "is not enough”, porque "Négritude is just one contribution...” (Said 280). Pero a James también se le critica y señala como ambiguo, pues, “James stubbornly supported the Western heritage at the same time that he belonged to the insurrectionary anti-imperialist moment...” (248). En fin, estos caribeños, dos francófonos y uno del Caribe inglés, coinciden en que la propuesta de Césaire beneficia al régimen colonial y asimilista en lugar de luchar contra él.

Por otro lado, existe la visión de la crítica del blanco occidental frente a la postura del escritor martiniqués. En 1994, Annie LeBrun discute la perspectiva del poeta en Pour Aimé Césaire, asegurando que las reacciones criollistas (créolistes), antes mencionadas, son el reflejo de una reacción típica ante el infructuoso intento de matar al padre de la négritude: Césaire. Para LeBrun, según aclara Rosello, “...Césaire embodies an eternal, universal principle of 'fundamental rebellion'; he is the Messianic leader who was able to give the Martinican people the "treasure of recaptured dignity”' (Rosello 479). Con esto, la figura de Césaire queda enaltecida como salvadora de la cultura de los negros. Aun más, otra mirada del blanco es la de Roger Toumson, ${ }^{22}$ quien describe al artista martiniqués como un “...négre inconsolée” (479), sin embargo, al mismo tiempo le defiende.

Más adelante, la recepción americana anglófona sobre las teorías postcoloniales y las preocupaciones filosóficas postestructuralistas crean otra perspectiva de la definición del término. Esta tendencia ve la négritude como un movimiento “...profoundly unradical, unrevolutionary, and ineffectual as philosophy of anticolonial resistance and postcolonial subjectivity” (74 Garraway). Esta crítica considera, al igual que Condé, que la vida política del autor se muestra en contra de las intenciones revolucionarias que promulga el movimiento al comienzo de la carrera literaria de Césaire. Entre sus principales detractores 
se encuentran Bill Ashcroft, Gareth Griffiths y Helen Tiffin, específicamente en The Empire Writes Back; éstos son críticos importantes que, junto con Soyinka, prefiguran los estudios postcoloniales.

Como se sabe, algunos pensadores estudian la négritude a partir de la mirada de Senghor, mientras que otros lo hacen conforme a la visión de Damas. ${ }^{23}$ El estudio y la crítica que hace Edward Said del concepto, en Culture and Imperialism (1993), corresponde a la idea que propone Senghor. ${ }^{24}$ Said advierte que el escritor senegalés plantea un análisis de mayor carga política, incluso mucho más que la intención primordial que Césaire le da al término. Este crítico añade que el movimiento produce un nacionalismo radical parecido al islamismo fundamentalista, el arabismo, etc. (214); y que la propuesta al comienzo se devela como insuficiente y crucial (Said 224), aunque luego asuma diferentes posiciones. No obstante, Said admite que el trabajo de Césaire, junto al de otros escritores como Salman Rushdie, C.L.R James y Derek Walcott, logra “...a reappropriation of the historical experience of colonialism, revitalized and transformed into a new aesthetic of sharing and often transcendent re-formulation” (351; mi énfasis).

Una mirada que difiere de las anteriores, es la que indica que la négritude es una propuesta humanista. Sobre esto, Doris L. Garraway apunta que el término apela a una consciencia racial que armoniza su construcción histórica. Así, inevitablemente, el movimiento es considerado un humanismo, pues, "[it] enable[s] the black man to imagine himself as human, thus demonstrating even more profoundly that Negritude is a humanism” (79). Sin embargo, Garraway no explica a cuál humanismo se refiere; aunque ésta no deja de señalar que la crítica acusa la négritude, precisamente, de ser una ética humanista: “devotion to this fundamentally humanist ethic in relation to the problem of anticolonial resistance" (83; mi énfasis). De todas formas, si ulteriormente el concepto resulta una especie de 
humanismo, entonces deben considerarse, según Garraway, las declaraciones de James A. Arnold, quien niega que se trate de un humanismo universal (124). Sin embargo Garraway le contradice afirmando en su análisis que la négritude, "is inseparable from the humanist dream of universal emancipation” (83). ${ }^{25}$ Para ampliar sobre lo indicado, otros estudiosos del movimiento observan que efectivamente négritude es una toma de consciencia del negro (Nigel Gibson) mientras que otros aseguran que se trata de una esencia universal (Nick Nesbitt).

En fin, el problema de la crítica es precisamente el de identificar la négritude como una teoría o propuesta que se ancla estrictamente en el factor racial. Los detractores pasan por alto que el elemento racial sirve de tropo para señalar la intención césairiana: aludir a que el negro reconozca lo que significa ser negro y, por consiguiente, lo que debe proyectar de sí a los otros o al Otro. ${ }^{26}$ La detracción que reclama que la négritude es un esencialismo no observa que el propósito de Césaire es justamente reconocer lo esencial: la cultura negra. Por lo tanto, el reconocimiento que busca Césaire es cultural e histórico. Así, considero aquí el concepto como una anticipación de la globalización cultural. Esto es, la négritude relaciona e integra múltiples prácticas culturales que surgen a partir de la esclavitud y del colonialismo.

\section{Propuesta de una metáfora: “Négreries: jeunesse noir et assimilation”}

El análisis de la négritude como metáfora surge aquí a partir del ensayo ya mencionado de Césaire, “Négreries: Jeunesse noir et assimilation”. De acuerdo a lo indicado, la négritude es considerada como la condición, cualidad o actitud del negro, desde y por sí mismo. Sobre esto, Césaire indica la necesidad de permanecer “...entre soi”, entre sí mismo, no dejándose asimilar. La intención del neologismo es fomentar la lucha para reencontrar y conservar las particularidades culturales del negro. Asimismo, postula una unidad panafricana extensiva a América. La construcción metafórica sirve como una petición o exigencia que hace Césaire 
al negro, de reconocerse a sí mismo para poder identificar así lo similar y lo desemejante con los demás. Por esto, la négritude coincide con los planteamientos de White sobre la metáfora: "Metaphor, whatever else it does, explicitly asserts a similarity in a difference and, at least implicitly, a difference in a similarity. We may call this the provision of a meaning in terms of equivalence or identity” (72). De esta manera, la négritude se define como una metáfora que provee significado en términos de equivalencia o de identidad.

Al redactar su ensayo, Césaire alude a que la juventud negra, incluyéndose, está en un tercer episodio de lucha: “la emancipación”. Además, añade que la primera etapa es el sometimiento: la esclavitud; seguida de la segunda fase: la asimilación. Tanto el sometimiento como la asimilación son formas de “determinar al yo como objeto, recluyéndolo" (Augusto 52) a esferas insignificantes y limitadas que ocurren sobre todo a partir del colonialismo. La négritude según Césaire es la incitación para obtener la emancipación que el negro debe hacer de todo lo que es ser negro (de y desde sí mismo). Este proceso es dinámico ya que activamente hay que escudriñar un comportamiento cultural aprendido, entenderlo, deshacerlo y reconstruir otro a partir de bases que no sean raciales. Por eso el autor explica que tanto la esclavitud como la asimilación son episodios pasivos y creativamente estériles, ${ }^{27}$ contrarios a la acción-creación: “Asservissement et assimilation se semblent: ce sont deux formes de passivité"; "La jeunesse Noire veut agir et créer" (“Négreries” 3). Con esto se obtendría posteriormente la emancipación.

El lector puede entonces notar, como lo hace la crítica, que el concepto enfatiza demasiado el elemento racial. Sin embargo, aquí el propósito de Césaire es cuestionar si lo racial determina la cultura del negro. De este modo, se apela a la necesidad de observar qué otros elementos hay que tomar en cuenta para definirse. Como se ha mencionado, algunos detractores hallan contradictorio que el poeta quiera liberar al negro del prejuicio y de la 
división racial apuntando precisamente al carácter étnico. No obstante, lo que el autor plantea con esto es un cuestionamiento sobre la separación de lo racial y lo cultural, sobre si es posible deslindar lo uno de lo otro. Al mirar la négritude como metáfora, se puede recargar su significado, en cuanto a equivalencias y desemejanzas, sirviendo de modelo epistemológico cultural para el Caribe. Inclusive, esto sucede en otros contextos y espacios geográficos que se asemejan con el caribeño, por ejemplo, en los grupos de islas colonizadas por europeos como en los archipiélagos de las Filipinas, Indonesia, las Polinesias y más. De esta manera, un modelo epistemológico que surge a partir del estudio de las dinámicas culturales que se dan en uno de estos lugares, sirve para expresar procesos paralelos y simultáneos en múltiples espacios; funciona por esto como representación de la globalización cultural.

Como ejemplo de las indudables diferencias culturales que existen entre los negros, que los tres autores fundadores del movimiento pertenezcan a distintas culturas, aun su clara relación racial, es evidencia de esa pluralidad cultural. Con esto, el surgimiento, existencia y permanencia del concepto négritude, no solo en la academia sino también en su uso popular, exige una transformación de la visión que existe del negro, desde esa multiculturalidad que rebasa el factor étnico. Césaire quiere que el color de la piel sea visto únicamente como la base de una raíz geográfica e histórica que va circunscrita a los eventos del colonialismo europeo. Por lo tanto, no se trata de una negación o contradicción de lo negro. Al contrario, el movimiento es una crítica en contra de aquéllos que niegan ser negros al asimilarse a la cultura del blanco colonizador. Los asimilados se convierten en blancos “culturales” aun siendo negros. Esto es precisamente lo que advierte Fanon en Peau noire, masques blancs: ser blanco cultural es llevar puesta la máscara blanca-occidental. ${ }^{28} \mathrm{Al}$ igual que Césaire, 
Fanon apunta a la subjetividad de la piel: “Ma peau noire n’est pas dépositaire de valeurs spécifiques” (Fanon 184).

En “Négreries”, aunque aun no aparece el vocablo négritude, quedan expuestas las intenciones del autor que le impulsan a la consiguiente creación del término. De esta forma, las subjetividades de Césaire sirven para la formación y comprensión de la metáfora. ${ }^{29}$ En el ensayo, expuesto de forma clara desde el título, la prioridad del poeta es sobre todo crear consciencia en la juventud universitaria negra para luchar en contra de la asimilación: "Les jeunes nègres d'aujourd'hui ne veulent ni asservissement, ni assimilation, ils veulent émancipation. [...] La Jeunesse Noire veut agir et créer. [...] Jeunesse Noire, il est un poli qui veux empêche d’agir: c’est identique et c’est vous qui la portez” (“Négreries” 3).

Para Césaire, la asimilación carece de sentido porque es un intento por cambiar la naturaleza y ésta es inalterable. El autor apunta que, “vouloir être assimilé, c’est oublier que nul ne peut changer de faune: c’est méconnaitre ‘altérité’ qui est loi de Nature” (3). Aquí, el escritor alude a una indeleble naturaleza del ser humano que no está ligada al color de la piel sino a su cultura. De ahí se reconoce la metáfora césairiana como representación de la libertad cultural y ésta como parte de la naturaleza humana.

Aun más, el poeta añade que para librar su lucha el negro debe tener fe en sí mismo y, para esto, es necesario poseer cierto grado de locura. Éste indica: “Je dirais volontiers que c'est folie, et je ne me souvenais que le fou est toujours, en un certain sens, 'l'homme qui a foi en soi'. Mais le Négre qui tue en lui le Négre, n’a point 'foi en soi', et c'est par là qu’il se sauvé de la folie” (“Négreries” 3). Para el joven martiniqués, el negro asimilado mata su propio ser, no tiene confianza en sí y por lo tanto se salva de la locura. De modo contrario, tener la capacidad de autoreconocerse y contradecir la asimilación que vive la sociedad colonizada requiere enloquecerse. En suma, este ensayo simultáneamente insta a la búsqueda 
y el desprendimiento de disimilitudes y aproximaciones; contradecir la asimilación es tomar consciencia de la existencia de la desemejanza incluso aunque esto signifique declararse loco.

Césaire asegura además que para ser uno mismo no basta con poseer la locura aludida, sino que, también, se debe luchar. Es decir, quien se acepta a sí mismo enuncia una batalla en su contra: “pour être soi, il faut lutter [...] qu’elle porté en elle des germes de lutte: lutte du même contre le même, c’est-á-dire, la pire des luttes” (“Négreries” 3). Sin embargo, paralelamente existe otra disputa en contra del asimilador-colonizador y de las creencias inculcadas bajo el colonialismo:

Il faut détruire l'indifférence, extirper l'obscurantisme, couper le sentimentalisme à sa racine: et ce qu'il faut couper surtout $[\ldots]$ :

Jeunesse Noire, il est un poil qui vous empêche d'agir: c'est l'identique, et c'est vous qui le portez.

Tondez- vous au ras de peur que l’identique n’échappe.

Rasez-vous:

C'est la première condition d'action et de création. (3) ${ }^{30}$

Entonces, aquí otro elemento de lucha que importa en la creación césairiana es el propósito de eliminar la indiferencia y de incitar a la acción.

Por otro lado, el ensayo también devela parte del plan que construye más tarde Césaire sobre la négritude vista como un movimiento artístico-estético. La propuesta persigue la idea de una formación cultural y estética del negro. Según indica el ensayista, ésta debe crearse desde el yo -hombre- ser humano antes que desde el yo-negro (reconociendo igual que el negro de Césaire no es africano, es un negro caribeño y sus motivaciones surgen desde ahí). ${ }^{31}$ Sobre esto, el autor indica que la juventud negra, “...veut avoir ses poètes, ses romanciers, qui lui diront à elle, ses malheurs à elle, et ses grandeur à elle;...” (“Négreries” 3). Se promueve precisamente esa dimensión multicultural, artística y estética, del negro. 
Asimismo, la denotación del término négritude coincide con una voluntad de lucha que difiere a la mencionada. Ciertamente, se buscaba romper los arquetipos que dificultaban una mirada descontaminada y así crear y no reproducir la ideología occidental. Por eso, la négritude no es una apología racial sino cultural que debe interpretarse más allá de la lucha del yo (particular). Más bien se trata de obtener la libertad intrínseca en todo ser humano. De este modo, la idea de la asimilación cultural es contraria a la de la négritude, pues, refuta la soberanía y liberación del yo independientemente del elemento racial. Por eso para Césaire la división racial obstruye la emancipación individual y afecta la libertad de cada individuo de aprehender su yo.

Tomando en consideración lo anterior, según indica Miller en "Conscience raciale et révolution sociale”, el poeta se apoya en ideas marxistas. Específicamente, Miller se refiere a cuando Césaire dice: "une condition est essentielle: rompre la mécanique identification des races,...” (Miller 747). ${ }^{32}$ Con esta aseveración, el escritor pide la eliminación de las divisiones raciales de la misma manera en la que Marx exige la supresión de las divisiones sociales (Miller). Sin embargo, este reclamo que hace Césaire es anterior, pues, está presente en el ensayo aquí estudiado. En un marco retórico marxista, el autor martiniqués define el problema de la raza como una disputa de revolución social y del capitalismo: "In "Nègreries” Marxism surrounds and defines the problem of race, as an issue of "social revolution" and capitalism” (Miller 744). ${ }^{33}$ El autor utiliza el neologismo négritude para deshacer conscientemente los arquetipos sociales establecidos, como lo hace Marx. Una vez liberados de la división racial, el acceso al yo se viabiliza, es abierto y paralelo al de todos. De haber alguna solución, no es la asimilación, delata Césaire, sino la aceptación de la diferencia como algo propio de la libertad humana. 
La idea del yo que interesa en el presente análisis es igual a la que establece Schelling (Augusto 179). Pues, éste alude al establecimiento de las diferentes formas del yo:

La esencia del Yo es libertad, es decir, no es pensable de otra forma, pues sólo se pone en tanto que Yo desde su poder propio absoluto, no como cualquier algo, sino como simple Yo. Esta libertad se deja determinar positivamente, pues no queremos atribuir libertad a ninguna cosa en sí, sino al puro Yo, puesto por sí mismo, presente por sí sólo, ... cuando queremos determinar al Yo como objeto, recluyéndolo en la esfera más insignificante y limitada posible, y bajo las condiciones del cambio, su libertad y autonomía desaparecen. (Augusto 52; mi énfasis)

Por esto, la libertad de la que habla Schelling es, precisamente, la misma que Césaire advierte en su concepción de la négritude. Cuando el autor habla de su repudio en contra de la asimilación, se refiere a que asimilarse implica cambiar las condiciones propias del ser humano, es limitar la libertad del yo. Además, para el poeta es peligroso tanto para el colonizador como para el colonizado. El primero, por una parte, incluso asimila lo que le disgusta de sus súbditos, supuestamente inferiores, llegando a temer a ese Otro cuando se reconoce ya asemejado a éste: “il a aussi le dégout du semblable”. Por otra parte, para el colonizado, una vez ve la semejanza que tiene con su formador-colonizador, éste no comprende su aun desprecio y, por consiguiente, le detesta (“Négrerie” 3).

De alguna manera Césaire anticipa lo que Said expone sobre la mirada del Otro en "From Orientalism” (1978). Uno de los argumentos del Orientalismo es que la investigación humanista debe formular la naturaleza de la conexión que hay entre política y cultura, junto al contexto específico y sus circunstancias históricas (Said 140). Asimismo, en Césaire se manifiestan vínculos culturales y políticos basados en eventos históricos relevantes. Así, al igual que Said, Césaire toma en cuenta que debe existir una responsabilidad humana en cuanto a la cultura, particularmente, en la relación que hay entre el conocimiento y las políticas. Hay que agregar además que ese vínculo establece una consciencia del yo a través 
de las correlaciones con los demás, con el Otro. Sobre esto, Emmanuel Lévinas indica en Ethics and infinity (1985) que la toma de consciencia humana, cuando trata sobre la percepción personal, está constituida por la existencia del Otro. ${ }^{34}$ Igual, éste añade que en ese sentido cada uno es responsable de ese Otro (Lévinas). ${ }^{35}$ Por lo tanto, el término négritude considera esta relación, entre lo equitativo y lo diferenciado, demarcándose así su construcción metafórica.

En Césaire, la creación del concepto expresa que la unión del negro surge a partir de la toma de consciencia de lo similar y lo desemejante. Esta concientización se logra reconociendo la dinámica que existe de la relación con los demás. Por ejemplo, aunque acaecen eventos históricos en común, éstos son percibidos por diferentes culturas y, por lo tanto, desde distintas perspectivas. Así, la tragedia de los abusos y las humillaciones del colonialismo son parte de la historia del negro, de su cultura:

Now their encounter as people of African descent regardless of where they were from would lead to the transformation of their individual feelings of revolt into a concept that would also unify all Black people and overcome the separation created by slavery but also by the prejudices born out of the different paths taken. (Diagne 2)

La concomitancia de un pasado histórico, aun sus diferencias y la separación física, permite la unión de los negros. Al reconocerse los elementos culturales se pone de relieve que el sistema colonial no surge por una especie de determinación étnica, sino por las construcciones sociales creadas, para su beneficio, por las estructuras de poder. De este modo la asimilación conviene para el funcionamiento de ese sistema. No obstante, para el autor esto pone en riesgo las respectivas culturas. 
Indistintamente, la metáfora construida por el poeta martiniqués proviene de sus prejuicios y luchas formados dentro de este mismo sistema:

Césaire has often evoked the embarrassment felt by people from the Caribbean at the idea of being associated with Africans as they shared Europe's ideas that they were now living in the lands of the civilized. He quotes as an example a “snobbish” young Antillean who came to him protesting that he talked too much about Africa, claiming that they had nothing in common with that continent and its peoples... (Diagne 2)

De esta manera, de acuerdo a Césaire, muchos habitantes del Caribe sienten vergüenza por estar ligados con los africanos. Éstos, los asimilados, sienten compartir más sus ideas con los europeos pues copian el discurso colonial aprendido. ${ }^{36}$ Por esto, otra posibilidad de la metáfora césairiana es afirmar que existe una diferencia marcada entre el caribeño, el europeo y el africano.

\section{El modelo metafórico}

Tomando en consideración todos los elementos ya mencionados, la négritude forma y afirma un modelo metafórico que representa para Césaire la cultura caribeña. Según Hayden White, al crearse una metáfora, debe ser inicialmente entendida en el marco de un pensamiento lógico y crítico que permita cuestionar su existencia y relación con la realidad. Para dar a entender esto, White asemeja su punto de vista a cómo Hegel define la poesía cómo el uso consciente de la metáfora sirve para liberar al humano de la sobre-determinación conceptual de las palabras:

...when undertaken in the interest of bringing logical thinking itself under criticism and questioning either its presuppositions, its structure, or its adequacy to an existentially satisfying relationship to reality, would be 
poetry, what Hegel defined as the conscious use of metaphor to release us from the tyranny of conceptual over-determinations. (White 10)

Así, la existencia de la metáfora afirma que el poeta, creador de ésta, pasa por un proceso de pensamiento lógico en el que representa su entorno. La creación de un término y su uso consciente fomenta una revolución abstracta que contradice la fijación conceptual del lenguaje. Para algunos lingüistas, esto surge de forma aleatoria y, por lo tanto, no es necesario ajustarse a esas determinaciones de la lengua. ${ }^{37}$

Ahora bien, la construcción de un tropo que permite vínculos entre los conceptos ya existentes amplían las posibilidades del pensamiento crítico. Esto es importante porque el mecanismo de crear metáforas es básico para el desarrollo del conocimiento:

Metaphorical consciousness may be a primitive form of knowing in the ontogenesis of human consciousness in its passage from infancy to maturity, but insofar as it is the fundamental mode of poetic apprehension in general, it is a mode of situating language with respect to the world every bit as authoritative as logic itself. (White 10)

De esta manera, en la négritude existe una intención amplificadora del concepto del negro. Esto es, Césaire crea un modelo cultural para tratar "hechos nuevos que se añaden al mundo", vinculando dos [o más] cosas distintas (Borges, “La metáfora” 114). Su ampliación surge “con la finalidad de” apelar a las “emociones” (115) para incitar un cambio. Por consiguiente, Césaire transforma una idea, crea un término y transmite con éste la búsqueda de la expansión y reafirmación cultural del negro antillano. 


\section{Reafirmación post-négritude: Globalización cultural}

A modo de preludio, Césaire advierte la imagen de la globalización cultural que existe hoy día con la distinción que éste hace entre el negro racial y el negro cultural. Como se ha indicado, el poeta exhorta a los negros a desprenderse de los prejuicios que tienen de sí mismos, reconociendo la historia pasada en común, logrando así que lo racial no determine su identidad. De ahí la relación con lo global-cultural, pues el escritor señala los enlaces y conexiones que surgen entre variadas culturas. La négritude permite crear un mapa epistemológico cultural que aporta al conocimiento global, facilitando que otras culturas apelen a esta dinámica que propicia Césaire.

El escritor martiniqués revela en una entrevista lo que le ha significado el haber conocido a Senghor y cómo esto le ayuda a configurar el término. Césaire habla sobre su colega senegalés:

Il m'a appris l'Afrique, la grandeur de l'Afrique, la noblesse culturelle de l'Afrique, [...] il m'a révélé l'Afrique, [...] je me suis rende conte qui me révélé, au même temps, a moi même, et qui me révélé La Martinique. Parce que, ....... les clés [...] sont en Afrique. [...] C’est fondamental : comment comprend la musique martiniquaise? Comment comprend le folklore martiniquais? Comment comprend le créole lui même, si on ne tient pas conscience de martiniquais. [...] Il faut! (« Le cercle de minuit », France2 1994) (mi énfasis)

Con esto, el escritor martiniqués reafirma la diferencia negra antillana pero en relación con la cultura africana. Para Césaire, conocer más sobre la historia y la cultura de África cuando llega a París le sirve de revelación. Es así que se abre ante el poeta otra realidad, la de sí mismo, la de su cultura caribeña, permitiéndole reconocer la diferencia en la similitud. Esto es, entre otra cosas, porque en el Caribe hay una angustia que no es africana: “...il 'y a chez les antillais une angoisse que n’est pas une angoisse africaine” (Césaire: Saligna Production, París 1995). 
Dicho de otro modo, la relación existente entre las Antillas y África se manifiesta ante los ojos de Césaire durante su exilio. Por esto, en 1994, el martiniqués reafirma que la négritude es un movimiento mucho más radical de lo que expone la crítica,

...plus radicale, et plus large et plus généreux. ... que souligne, une fidélité et un devoir de mémoire. ... Ce n’est pas du tout la qualité africaine, non... c’est aspect de l’héritage, parce que c’est négligé, parce qu’avilit, parce que de poésie, ca c’est le gras que je veux revendiquer, et c’est pour ce là. ... Il fallait rétablir une vérité historique. ${ }^{38}$ («Le cercle de minuit», France2 1994)

Por esto, en el término négritude hay una alusión directa a la cultura antillana como separada de la africana. Para el poeta, aunque existe el deber de la recuperación de la memoria, que está relacionada con el legado de África, hay que restablecer una historia que no es parte de esa herencia; proviene de las Antillas. El concepto no señala únicamente la lucha contra la asimilación, igual (re)crea una consciencia del negro caribeño y la (re)ubica en relación con la cultura de África: una dinámica de separación física - unión de pensamiento crítico separación cultural (separación - unión - separación).

De la misma manera en la que Césaire reconoce la posibilidad de usar el elemento racial como metáfora o modelo epistemológico estético de la cultura en las islas antillanas, otros caribeños llevan a cabo esta labor. El cubano Nicolás Guillén crea el negrismo o poesía negra, una idea enlazada con la négritude, aunque ésta trata la representación de la cultura africana específicamente en el Caribe hispano. ${ }^{39}$ Guillén, igual que Césaire, escribe para la década del treinta (incluso desde antes) y muestra la síntesis de elementos culturales entre los negros y los blancos. A esto, también se le denomina como la poética del mestizaje (DunoGottberg). ${ }^{40} \mathrm{Al}$ mismo tiempo, Luis Palés Matos en Puerto Rico escribe su poesía negroide en Pueblo negro (1926) y en Tuntún de pasa y grifería (1937), ${ }^{41}$ resaltando la cultura negra 
en la isla caribeña. Todos estos autores, junto con el poeta martiniqués, hacen hincapié en lo racial para definirse y, desde ahí, no solo mostrar al negro, sino expresar ese elemento particular dentro del entramado heterogéneo de la cultura caribeña. ${ }^{42}$

La posición canónica literaria que hoy ocupa la obra de Césaire hace que éste sea reconocido como parte de lo que llaman literatura universal. ${ }^{43}$ Esto significa que sus textos (o al menos varios de ellos) se presentan y perpetúan en la esfera de lo cultural: a través de las artes, el pensamiento académico y más. La fijación de una obra en el canon surge a pesar o a la par de unos parámetros políticos, sociales e históricos. Así, inscribirse en el canon también es parte de la intención de Césaire. El poeta quiere que el negro (y él mismo) sea parte de un censo "global” o “universal”, estético, artístico, literario, etc. De esta forma, logra su propósito de insertarse en la universalidad del ser humano: “...contribuer à la vie universelle, à l’humanisation de l’humanité” (“Négreries” 3). La négritude al hacerse parte del canon cumple con la intención de Césaire: “Il faut se conservée ou se retrouver” (3); sirve como método de archivo que viabiliza la conservación de la cultura artística negra.

La obra césairiana fluctúa entre no pertenecer al canon, por ser parte del Caribe periférico, y vincularse a éste. La négritude forma parte de una literatura clave occidental: ahora es céntrica, no marginal. Un ejemplo de esto es que Césaire aparece en las antologías de escritores que aportan al pensamiento francés; su trabajo es crucial para la historia del conocimiento del siglo XX. ${ }^{44}$ No obstante, esta inserción del poeta en el canon logra una separación con lo marginal y, simultáneamente, la unifica: de lo centralizado con lo periférico y viceversa. Aquí, lo marginal es también metacéntrico e igualmente multicéntrico, pues, la periferia está expuesta en un espacio, en una sola mirada, que representa la dinámica misma que define la cultura caribeña. 


\section{Capítulo 2:}

\section{La transculturación y la négritude: contrapunteo racial-transcultural}

\section{La transculturación}

En Contrapunteo cubano del tabaco y el azúcar (1940), Fernando Ortiz acuña el término transculturación. Una de las intenciones del antropólogo es transformar ciertas expresiones etnográficas porque las considera inexactas. Así, el autor plantea un trueque terminológico de aculturación (voz que proviene del inglés) a transculturación, contando con el respaldo de Bronislaw Malinowski (1884-1942), quien es “tal vez el antropólogo más célebre del mundo” en ese momento (Santí 50). Para Ortiz, el primer concepto es equívoco ya que no ilustra el verdadero contexto que suscita del encuentro de dos o más culturas, por lo que no define eficazmente la realidad cultural cubana ni, por ende, la caribeña.

En la introducción de Contrapunteo..., Malinowski precisa que aculturación presupone un carácter etnocéntrico. Éste indica que el vocablo sugiere que, “el inculto” ha de recibir los beneficios de la cultura dominante, viéndose en la parvedad de cambiar para convertirse en uno más de esa cultura que impera (125). Es decir, una cultura queda sometida a otra. ${ }^{45}$ El escritor cubano refuta lo anterior al crear la noción de transculturación para aludir a “un proceso en el cual siempre se da algo a cambio de lo que se recibe”, mostrando que el choque de culturas es una acción multilateral: “un proceso en el cual ambas [o más] partes de la ecuación resultan modificadas..., [en el que] emerge una nueva realidad, compuesta y compleja; ...un fenómeno nuevo, original e independiente” (Malinowski 125).

Morfología y etimología de transculturación

Partiendo de un argumento lingüístico, ${ }^{46}$ Ortiz propone un cambio semántico para “expresa[r] mejor las diferentes fases del proceso transitivo de una cultura a otra” (Ortiz 260) y no la simple adscripción de una de las partes culturales. ${ }^{47}$ Por esto, al intercambiar el 
prefijo a-, “privar o negar algo”, por trans-, “al otro lado” o “a través de” (RAE 2001), traslucen los propósitos del autor: crear una conciencia cultural travistiéndose ${ }^{48}$ de realidad a través de un proceso analítico y creativo. Con transculturación, el escritor identifica lo cubano y caribeño a través de las relaciones de poder entre las diferentes culturas y etnias, tratando de eliminar así la posible ambigüedad que éste supone los lectores infieren con el prefijo $a .^{49}$

A primera vista, al abordar el Contrapunteo... es evidente que su organización o estructura no es ordinaria. Luego de la introducción de Malinowski, el inicio del trabajo de Ortiz es el ensayo del “Contrapunteo cubano del tabaco y el azúcar”, seguido del “Capítulo primero" que, en lugar de formar una secuencia con respecto al estudio inicial, ilustra un breve esclarecimiento de esa sección anterior. Las afirmaciones que tiene el texto en el discurso de apertura, según Ortiz, bien "podrían ser acompañad[a]s de una amplísima y sistemática documentación distribuida en notas”. Aunque éste asegura no hacerlo porque afectaría la naturaleza de su trabajo. Sin embargo, el autor adecúa al contenido una "multitud de datos y documentos, glosados” (251). Luego, para sorpresa del lector, el grosor mayor de la obra está en capítulos complementarios de los que, según advierte Ortiz, puede prescindirse, ya que supuestamente solo sirven para suplementar el ensayo principal. Para mayor desconcierto, después de esta efímera explicación, aparece un bosquejo a modo de índice que, en lugar de mostrar una enumeración ordenada, está dividido en dos conjuntos temáticos disímiles.

La disposición del libro de Ortiz revela precisamente su forma contrapuntística. A diferencia de la noción de la transculturación, que surge, bulle y se transforma, el contrapunteo funciona como una especie de marco volátil que precisamente permite el surgir, bullir y transformarse de la transculturación. Esto supone que el contrapunteo, es decir, la 
configuración preliminar del texto, es una “Concordancia armoniosa de voces contrapuestas” (RAE contrapunto). Así, simboliza lo que se denomina como una “...composición á dos ó muchas partes diferentes, trabajadas según las reglas del mismo. Antiguamente eran simples puntos, y cuando se quería añadir una ó más voces á una melodía, se añadían mas puntos, juntándolos unos sobre otros, ó el uno contra el otro” (Fargas y Soler 52-3). Ortiz sugiere una intención de abarcar todo carácter comprendido en un contrapunto, pues, del mismo modo que en la música existe el doble, el de fuga o el simple, Ortiz muestra que su propuesta también provee estas formas: "que puede ser invertido; esto es, cuando la parte alta puede hacerse pasar al bajo y vice-versa” (doble), e igual, que existen “imitaciones, cánones y otros artificios del arte de componer ó escribir música” (fugado). Por otra parte, la polifonía estructural del texto puede leerse también como "susceptible de ser revuelto o invertido" (simple) (Fargas y Soler 53). ${ }^{50}$

El escritor deja abierta la posibilidad para el lector, ya que aquél no "pretende que las señaladas contraposiciones... sean todas tan absolutas y tajadas como a veces se presentan...” (Ortiz 251). Con esto, el contrapunteo propone una “...trama discursiva [que] se acepta como su modo de leer la historia y la cubanidad” (Díaz Quiñones 294). Ortiz recurre a este patrón estructural porque “el 'contrapunteo' funciona ya en un plano conceptual como categoría de análisis, ya en un plano literario como lucha simbólica” (Weinberg 31). Así, se advierte que la configuración del libro sirve precisamente como metáfora.

Ortiz crea una estructura en la que ofrece “sus opiniones sobre el “Contrapunteo” dentro del Contrapunteo, y no en una nota o prefacio” (Benítez-Rojo 179). ${ }^{51}$ En La isla que se repite, ${ }^{52}$ Benítez Rojo indica que el propósito del antropólogo cubano es eliminar una alusión subordinada de la temática del libro; evita presentar “una relación de jerarquía semiológica 
entre dos o más” obras. Además, éste dice que Ortiz está consciente "que ningún texto tiene la capacidad de abordar la realidad que desea significar” (Benítez-Rojo 179). Por lo tanto, de acuerdo a la disposición escogida, de antemano existe un enlace de la estructura con la relación establecida de las representaciones figuradas del tabaco y el azúcar. Dicho de otro modo, es un entramado metafórico, incluso alegórico, ${ }^{53}$ que se dispone como vehículo y tenor; que "se sabe insuficiente de antemano” y "no pretende alcanzar la verdad” (Benítez Rojo 79).

Esto ya supuesto, considerando que la metáfora es una figura retórica que sirve como medio para explicar fenómenos, siendo ésta verdadera y falsa simultáneamente (Borges, "La metáfora” 114), de igual modo, contrapunteo y transculturación funcionan como tal. La organización del trabajo, que adopta la técnica musical del contrapunto, y el vocablo transculturación sirven como tropos epistemológicos que representan la cultura del Caribe. Estos conceptos tienen el propósito deliberado de identificar y vincular dos o más nociones, “Ambas son una vinculación tramada entre dos cosas distintas, a una de las cuales se la trasiega en la otra” (Borges 114). Y, “En efecto, estos fenómenos pueden relacionarse entre sí por la vía de sus semejanzas, o bien pueden disponerse como polos antitéticos atendiendo a su antagonismo” (Benítez Rojo 180).

Resulta claro que el uso de metáforas en una arenga es consciente, así también los términos de Ortiz. El antropólogo cubano crea un texto que "tiene consciencia de sí mismo y que nos comunica que aquello que pudiéramos interpretar como verdades son, más bien, decisiones arbitrarias para conformar la estrategia del discurso” (Benítez Rojo 180). De esta forma, el lenguaje empleado "no es más que la realización de uno de tantos arreglamientos posibles” (Borges, “Examen...” 71). Por eso el lector no puede olvidar, al enfrentarse al ensayo orticiano, que existe un evidente "relativismo [que] es posible gracias a los múltiples 
factores que intervienen en la formación de dichos fenómenos” (Benítez Rojo 180). En Contrapunteo..., la dinámica estructural proporciona mayor significación a la propuesta de transculturación que, en tanto metáfora cultural, su estrategia recae en todos los eslabones que forman parte “del juego infinito de las imposibilidades” (Benítez Rojo 181), ${ }^{54}$ delimitando así apropiada y subjetivamente el artilugio que representa la cultura del Caribe.

Al ilustrar el portento cultural de su isla, Ortiz va más allá de identificar una dinámica tomada de un discurso literario y una forma musical. A través de los productos agrarios principales de la historia cubana, el tabaco y el azúcar, el libro representa la diversidad de los grupos humanos, específicamente de las pluralidades raciales que forman la sociedad caribeña a través de su historia. Mientras el escritor enfrenta contrapuntísticamente ambos bienes económicos, al mismo tiempo, éste va señalando elementos de la cubanidad:

...their culture, musicality, humor, up-rootedness, their baroque manner of refashioning their identities by integrating the fractured meaning of multiple cultures [...] Ortiz treats tobacco and sugar as highly complex metaphorical constructs that represent at once material things and human actors. (Coronil xxvii; mi énfasis)

Por lo tanto, el antropólogo muestra cómo la relaciones sociales-raciales se definen a través de ciertas condiciones históricas. Ambos, tabaco y azúcar, son elementos que construyen la cultura cubana, sus respectivas “narraciones” y relaciones de producción.

\section{El ideario del texto}

La compilación de ideas en el contrapunteo ilustra una temática análoga a la de las doctrinas religiosas que los esclavos africanos traen a América y el Caribe. Es cierto que este ensayo de Ortiz no apunta directamente a la relación entre la disposición del texto y las dinámicas de los dogmas africanos en la isla. No obstante, este sistema de creencias sirve 
para describir las metáforas de Ortiz: la forma en que define su concepto y los acercamientos históricos que coloca en su alocución antropológica. Por ejemplo, Benítez Rojo hace mención de los elementos que componen la fe africana y aunque aquí éste no busca revelar la erudición de Ortiz, el lector puede notar que la correspondencia está presente; resulta fácil relacionar las ideas de estos dogmas religiosos con las del contrapunteo sobre la cultura cubana. Benítez Rojo menciona que la creencia africana es

...un verdadero cuerpo de prácticas socioculturales que se extiende por un laberinto de referentes tan diversos como son la música, la danza, el teatro, el canto, el vestuario, el tocado personal, la artesanía, la literatura oral, los sistemas de adivinación, la botánica medicinal, la magia, el culto a los antepasados, la pantomima, los estados de trance, las costumbres alimentarias, las labores agrícolas, las relaciones con animales, la cocina, el intercambio comercial, las observaciones astronómicas, el comportamiento sexual e, incluso, las formas y colores de los objetos. (Benítez Rojo 186)

A pesar que lo aquí citado es una enumeración de la praxis de la fe africana y no es la intención del autor aludir al contrapunteo orticiano, aún se observa una concordancia entre ambas dinámicas. Sin duda, el ideario del texto de Ortiz puede equipararse a este sistema de creencias. $^{55}$

La obra orticiana es "un discurso que permea toda actividad humana e interfiere en todas las prácticas” (Benítez Rojo 186). Por esta razón es que las creencias religiosas en Cuba son las fuerzas que unifican “-el mito, la ideología- que” propician "la prolongada resistencia colectiva del esclavo hacia el sistema de plantación” (187). De igual manera, "la doctrina espiritista es, como veremos, un aspecto fundamental en los orígenes del concepto de transculturación” (Díaz Quiñones 295). Es decir, el texto de Ortiz es un maderamen alegórico que funciona como síntesis de la historia caribeña, incluyendo necesariamente los dogmas religiosos; sirve de contexto y sumario de los efectos de sus dinámicas, se delimita a través del contrapunteo y de la creación del concepto transculturación. 


\section{Transculturación: creación, (re)creación, contexto}

La transculturación es una noción formada para “expresar los variadísimos fenómenos que se originan en Cuba por las complejísimas transmutaciones de culturas” que surgen en la isla. Sin demarcar estas transformaciones “...es imposible entender la evolución del pueblo cubano, así en lo económico como en lo institucional, jurídico, ético, religioso, artístico, lingüístico, psicológico, sexual y en los demás aspectos de su vida” (Ortiz 254). Asimismo, cuando Ortiz elabora el neologismo toma en cuenta la realidad histórica de Cuba, como también elementos teóricos y poéticos. ${ }^{56}$ Por esto, hay que reconocer el contexto político que influye en la publicación de la obra (1940), periodo en el que la isla experimenta la nueva Constitución de la República. ${ }^{57}$

Ahora bien, más allá de presentar un carácter político, el texto propone una “concertación nacional” (Santí 49) que busca redefinir la situación de la isla, ampliando y justificando la manera en la que debe identificarse lo cubano-caribeño. De acuerdo con Arcadio Díaz Quiñones, la transculturación permite “construir un metarrelato de la cultura nacional [y supranacional] basado en una larga reflexión sobre la hibridación y la mezcla” (294). Así, desde una mirada antropológica e histórica, este concepto funciona "como medio indispensable para conseguir el fin último..., la integración nacional y el robustecimiento de la soberanía nacional” (Naranjo-Orovio 157). ${ }^{58}$

El trabajo de Ortiz es una constante reformulación de las tradiciones nacionales. Éste incluye las afirmaciones de otros cubanos (Saco, Varela, Martí y otros) (Arcadio 294), validando así su proyecto que origina “un diálogo fundacional en su definición del ‘carácter’ nacional” (Arroyo 29-30). Entonces, tomando en cuenta lo que afirma Hommi Bhabha en The Location of Culture (1994), la idea de la nación está alienándose constantemente, convirtiéndose en un lugar simbólico, “un espacio significante liminar que está internamente 
marcado [y formado] por los discursos de minorías, las historias heterogéneas de pueblos rivales, autoridades antagónicas y tensas localizaciones de la diferencia cultural” (Bhabha 184). En efecto, la noción de transculturación demarca estos rasgos distintivos de la sociedad cubana, mencionados por Bhabha, además de todas las inter-engranadas transculturaciones que coexisten en el Caribe (Coronil xxv). ${ }^{59}$

\section{La metáfora cultural caribeña}

Cuando Ortiz transforma el término proveniente del inglés, conscientemente, hace un intercambio morfológico de la palabra. No obstante, el concepto mantiene la forma escrita del sufijo de aculturación. Así, el afijo complementa la expresión metafórica, pues, su significado expresa la representación de acción y efecto (RAE -ción). Por un lado, la acción está en el marco estructural contrapuntístico que vincula indefinidamente dos o más elementos a manera de forma musical y requiere análisis tanto en un plano simbólico como literal. Asimismo, esta estructura delinea la dinámica de la transculturación puesto que, simultáneamente, sus vinculaciones ponen de relieve las diversas e intrincadas transmutaciones de culturas. Por otra parte, el efecto es la alocución cultural de la mixturación social y racial. Mediante analogías, el antropólogo ilustra esta abstracción a través de las relaciones de producción del tabaco y el azúcar. La evolución histórica de estos materiales económicos, sus usos, sus técnicas y sus consecuencias, representan la formación de la cultura antillana.

Ortiz explica que a lo largo de la historia, la cultura cubano-caribeña pasa por varios periodos de transculturación. Este proceso sucede desde sus orígenes, a partir de la era paleolítica y neolítica, con la fusión de las sociedades indígenas (Ortiz 254). Así, al momento de la invasión y conquista europea en América, ya la cultura de los habitantes de estas tierras está inevitablemente transculturada. De este modo, el tabaco representa la 
evolución y mixtura cultural indígena; así como la llegada de las culturas europeas y africanas en el Caribe se ilustra con el carácter heterogéneo del azúcar. ${ }^{60}$

Tabaco

El tabaco y su carácter autóctono transculturado simboliza el inicio del desarrollo cultural cubano. Desde el comienzo de la obra el autor devela las intenciones que tiene respecto a los tropos que utiliza. Sin embargo, en el capítulo octavo, Ortiz hace aún más evidente su propósito al ampliar sus observaciones sobre este producto. En esta sección del libro, bien pueden sustituirse las aseveraciones sobre la planta por el proceso de la cultura aborigen de las Antillas.

Así, semejante al indígena de la isla, "La mata de tabaco se aprovechaba toda ella, según sus varios usos: las semillas, las raíces, el tallo, las hojas y las flores” (Ortiz 289). Sobre esto, el autor muestra un ideograma de la acción de los colonizadores, de aprovechar abusivamente y en su totalidad la mano de obra de los nativos. En parte, el resultado es el rápido exterminio de los aborígenes en el Caribe. ${ }^{61}$ Asimismo, los métodos y usos que conlleva la producción del tabaco repercuten en la forma en que la cultura cubana evoluciona: "la sustancia del tabaco se consumía sola o mezclada con otras yerbas o sustancias de diversas índole, según los efectos fisiológicos que se deseaban,...” (290; énfasis mío). Precisamente, esto es lo que sucede con los habitantes oriundos antillanos. Los indígenas se disipan solos o mezclados, por y con los europeos que llegan a las "nuevas" tierras; esto resulta en diferentes efectos fisiológicos, o bien genéticos, evidenciados en la constitución física transfigurada de los pobladores de la cultura emergente. Aquí el uso de imágenes que hace Ortiz aluden, en particular, al mestizaje racial que se da en el Caribe. Sin embargo, tanto la transculturación como el término de sincretismo se refieren, al contrario, a una mezcla cultural. 
Desde otro punto de vista, Ortiz adscribe al aborigen dentro de una génesis equiparable al de las creencias occidentales. De esta manera, el autor crea una validación de la periferia colonizada frente al conocimiento europeo. Un ejemplo se observa cuando se indica que en la mitología fundacional de América existe semejanza con “el diluvio, con el patriarca Noé y sus hijos repobladores del mundo" (Ortiz 294). Con esto, el texto valida al indígena al compararlo, incluso poniéndolo superior, con las otras culturas que eventualmente llegan. El mito antillano a través del “folklore primitivo es símbolo también genésico, como la culebra bíblica” (294). Además, se alude a la plausibilidad de la fuerza fecundadora del tabaco en relación con las mitologías paganas occidentales, señalando que, “...acaso el tabaco o cigarro por su forma pudo tener también un simbolismo priápico y ser el humo y la picadura como figuraciones de la potencia seminal que penetra, fecunda y anima la vida en todas las manifestaciones” (297). Por otra parte, éste también alude a que Tlaloc, dios azteca de las aguas, usaba el tabaco para lanzar humo para producir lluvia y fecundar la tierra. ${ }^{62}$ El antropólogo compara esta deidad americana con Afrodita, que "se vestía o transustanciaba con el tabaco”, todo “Un completo ciclo mítico” (298). Entonces, es evidente la creación y reafirmación de una validación genésica y masculina de la cultura aborigen a través de la representación de esta planta y sus usos.

En el estudio minucioso que hace Ortiz además explica la forma en la que los diferentes grupos aborígenes utilizan la planta. Éste menciona varios pueblos indo-antillanos, como los caribes de las Antillas; añade a los incas, los mayas, los aztecas, el uso que le dieron los negros, los españoles (y europeos en general) y otros más. El autor se apoya en documentos antropológicos como las crónicas de los conquistadores, dibujos e imágenes de utensilios que se utilizan para la fuma del producto, etc. Mostrar la evolución de los métodos y usos del 
tabaco, ${ }^{63}$ evidenciando los cambios y las mezclas que existen, ilustra la transculturación de este producto como ejemplo epistemológico que revela la cultura antillana transculturada.

Más que tratarse de una simple metáfora del tabaco, el trabajo orticiano apunta a una alegoría de todo el proceso que enlaza la cultura caribeña. Aún más interesante, con este entramado alegórico como representación cultural del Caribe, también trasluce la muy estudiada relación de los sincretismos religiosos que surgen en América. Sobre esto, el autor advierte que los actos rituales aborígenes y los efectos intensos que el tabaco produce en los taínos, son análogos a lo que sucede en la sociedad de la isla. Por ejemplo,

[En] Cuba y en Haití en relación con los fenómenos de posesión de santos en las religiones africanoides, y en los trances de mediunmidad espiritista. Unas personas caen en seguida en estado de posesos mientras otras tardan o resisten sin rendirse, pese a todas las invocaciones, pases, ritos y toques de tambor. (Ortiz 330)

Aquí, la idea de Ortiz es relacionar distintos aspectos que forman parte de la cultura antillanaamericana para así ejemplificar sus fenómenos. Por esto, el autor no limita su trabajo a mostrar un análisis detallado antropológico del tabaco, sino que recurre a estas bifurcaciones, aquí religiosas, para crear una dinámica similar al proceso transcultural que ilustra y valida. "Hay en esta suerte de fenómenos psíquicos ciertas favorables predisposiciones e idiosincrasias individuales, que mediante la práctica reiterada y la sugestión colectiva se suelen extender fácilmente a un grupo social humano” (330-1).

Azúcar

De la misma forma que el tabaco ocupa la parte inicial o voz primera de la metáfora cultural caribeña de Ortiz, el azúcar aparece como complemento necesario que continúa el contrapunto (la segunda voz). Con esto, el autor explica otras dinámicas sociales que 
también caracterizan el espacio antillano. A partir del capítulo XI, el texto provee un análisis que parte de la presentación de documentos “históricos” sobre el azúcar, abarcando sus inicios, los procesos por los que la materia pasa, incluyendo con esto la introducción de los negros en América. ${ }^{64}$

El carácter múltiple que tiene el azúcar sirve de tropo. Esto se ilustra a través de las distintas denominaciones que recibe históricamente este producto. A los diversos nombres que adopta el azúcar se les designa "bien añadiéndole al nombre sustantivos genéricos de caña algún adjetivo o algún calificativo de procedencia” (Ortiz 530). También, estos “adjetivos adicionados a la palabra caña para indicar alguna especificación han sido varios”; e igual “...se adhiere[n] al sustantivo fundiéndose en un solo vocablo” (530). Es interesante notar cómo, junto al carácter plural del azúcar, incluso lingüísticamente, “por razón de su apetecida sustancia mercantil”, además se utilizan nombramientos que a veces son impropios (532). Ortiz hace esta aclaración para especificar que, “dentro y fuera del idioma, continuarán no pocos usos, vulgares e igualmente corrompidos pero mucho más trascendentes y dignos de abominación,...” (535).

Ahora bien, la representación del azúcar apela claramente a la cultura blanca europea. Primero, es evidente que la introducción de este producto en Cuba, o bien de los españoles, adscribe consecuentemente a la cultura negra, ya que "el imperativo económico exigía tan sólo aparatos de fuerza muscular” (565), sustituyendo así la mano de obra esclava indígena con la de los negros (563). La prosopopeya del azúcar como causante de la esclavitud, primero de los aborígenes y luego en contra de los negros, está evidenciada con los documentos históricos y crónicas que cita Ortiz. De esta forma, el autor demanda al lector un intercambio simbólico del vocablo azúcar por el del blanco o incluso, específicamente, por las consecuencias del coloniaje europeo en América. 
Las características utilizadas en el texto para denominar el azúcar son propias de la cultura blanca. De hecho, las palabras que el autor escoge, a medida que se adelanta la lectura, van haciéndose más evidentes. El azúcar y su rol de conquistador representan la violencia de la colonización a fuerza de “machetazos, trituraciones, prensados, hervideros, centrifugaciones vertiginosas e incesante trasiego y traqueteo...” (Ortiz 184). La herencia que la cultura caribeña obtiene del proceso del negocio azucarero es violenta, marca su siempre corrupción, herencia falseada, mermas y polarizaciones a base de engaños (182). Entonces, aquí no es necesario continuar la mención de vocablos que el antropólogo asocia al azúcar y a su producción para reconocer la evidente intención metafórica: mostrar las relaciones de poder existentes en las dinámicas raciales-culturales que provee la introducción del producto extranjero y su manufactura en las islas caribeñas.

Del azúcar al lenguaje

Además de hacer alusión sobre el azúcar y su personificación, Ortiz aclara la arbitrariedad que existe en el idioma. ${ }^{65}$ Acerca de la selección de vocablos en el texto, cuando el autor comienza el desglose del producto azucarero indica que

Al fin, todas las palabras son convencionales y sólo dicen lo que los interlocutores entienden por ellas y no lo que pensaron sus creadores, ni lo que los lingüistas quieren poner en ellas por razón de su raíces, de su sentido originario, o de la simple lógica de la estructura. Pero, de otra parte, no es imperativo ni prudente que ante un uso generalizado y casi unánime tenga que rendirse el hablista o escritor cuando, llevado por impulso literario y en ocasión apartado del vulgo y del trato familiar o común, quiera usar el vocablo que crea mejor formado y mas preciso de sentido por su exacta armonía entre las raíces que lo constituyen y su significación inequívoca. (Ortiz 529; mi énfasis) 
Aquí radica la intención metafórica del trabajo orticiano: el escritor desvía el uso popular de varios términos dándoles otro sentido para definir la cultura cubano-caribeña. No se trata estrictamente de aclarar la historia de la lengua española mencionando las distintas formas de nombrar el azúcar y la caña, sino que el ensayo apela al uso deliberado que hace el autor para eliminar los modos convencionales de los conceptos que utiliza. Al Ortiz hacer esta aclaración, el entramado alegórico resulta mucho más viable. Sobre esto, de acuerdo a Cornejo Polar, “el empleo de estos préstamos semánticos desplaza una densa capa de significación que engloba y justifica cada concepción de las cosas” (“Mestizaje...” 7). Por lo tanto, el antropólogo y escritor cubano articula elementos de la cultura antillana, incluyendo y confirmando cada idea de los objetos, a través de tropos, porque "la lengua más abundante se manifiesta alguna vez infructuosa y necesita de metáforas” (Borges, “Examen...” 70).

\section{La metáfora}

Desde el inicio del texto de Fernando Ortiz, Contrapunteo cubano del tabaco y el azúcar, se alude a la construcción de un tropo literario. Comienza con la mención de la obra del poeta español medieval Juan Ruiz, el arcipreste de Hita. Con esto, indica Fernando Coronil, el libro de Ortiz abre una interpretación sumamente metafórica de la historia cubana (xx). Asimismo, al continuar la lectura se advierte que todo es un entramado alegórico que continúa esta metáfora inicial. La estructura del escrito orticiano funciona entonces como “Figura que consiste en hacer patentes en el discurso, por medio de varias metáforas consecutivas, un sentido recto y otro figurado, ambos completos, a fin de dar a entender una cosa expresando otra diferente” (RAE alegoría).

De este modo, hay que recurrir a una constante reinterpretación del texto. Esto es ya que el contrapunteo no solo tiene carácter estructural sino también simbólico. Primordialmente porque “...Ortiz wishes us to read this text in the same way that he reads tobacco and sugar: 
as complex hieroglyphs that elude definitive decoding. Through the interplay of these two readings the essay may seem at once to stand by itself and to call for continuing reinterpretation” (Coronil xiii). Así, los distintos niveles de interpretación que adquiere el ensayo se presentan, entre otras cosas, a través del uso que hace Ortiz de varios símbolos, como los mencionados: el tabaco y el azúcar. Estos símbolos facilitan la posibilidad de reinterpretar la propuesta del antropólogo cubano incluyendo la estructura del texto.

En el estudio minucioso que hace Ángel Rama en su libro Transculturación narrativa en Latinoamérica, hay una ampliación del concepto de Ortiz. Rama propone varias fases del proceso de transculturación. Primero, éste habla de una etapa inicial de desculturación parcial, refiriéndose a la pérdida de elementos culturales ya considerados obsoletos. Luego, está la etapa de la incorporación de elementos de la cultura foránea, que finalmente desemboca en una recomposición que provee equilibrio entre los elementos persistentes de la cultura original y los que vienen de afuera (Rama 45). A diferencia de Ortiz, Rama, al utilizar este concepto tiene una intención más armoniosa. ${ }^{66}$ Este último explica que, aunque siempre

Habría pues pérdidas, selecciones, redescubrimientos e incorporaciones[,] Estas cuatro operaciones son concomitantes y se resuelven todas dentro de una reestructuración general del sistema cultural, que es la función creadora más alta que se cumple en un proceso transculturante. (47)

Sobre esto, la crítica de Cornejo Polar es que el proceso que propone Rama es erróneo por su intención homogeneizante. Los detractores de Rama advierten que en la cultura latinoamericana el resultado de la transculturación (o de la hibridez o mestizaje) no puede ser homogéneo sino que, al contrario, es de inevitable carácter heterogéneo: "Después de todo el símbolo del ‘ajiaco’ [y el de transculturación] de Fernando Ortiz ${ }^{67}$ que reasume Rama bien 
puede ser el emblema mayor de la falaz armonía en la que habría concluido un proceso múltiple de mixturación” (Cornejo-Polar, “Mestizaje...” 8). ${ }^{68}$ Habría que agregar que Cornejo Polar además refuta que estos conceptos buscan resolver las complejas relaciones que existen en la cultura americana. Éste indica que las interpretaciones de Ortiz y Rama están basadas en que todo queda "armonizado dentro de espacios apacibles y amenos, (y por cierto hechizos), de nuestra América” (“Mestizaje...” 8).

No obstante, Benítez Rojo contrariamente propone que no hay un intento de armonía en la creación del Contrapunteo..., sino que su punto es exponer la exageración, complejidad y sentido incompleto que permite definir la cultura caribeña y la de todo el continente americano. Inclusive, la estructura contrapuntística que utiliza Ortiz contradice lo que Cornejo Polar advierte. La dinámica del contrapunto refleja que no existe una armonía completa, más bien "no involucra una paridad, ni tampoco una síntesis derivada de la contradicción tesis/antítesis”, pues se trata de una “relación compleja y crítica, imposible de clarificar del todo” (Benítez Rojo 205).

Estos conceptos muestran los procesos problemáticos que existen en la configuración cultural a partir de la idea de la heterogeneidad. Arroyo amplía la crítica que Cornejo Polar tiene al respecto:

Para Cornejo Polar, el mestizaje no sólo definía el latinoamericanismo en su sentido más tradicional, sino también desplazaba una serie de conflictos reales entre razas, clases, lenguajes y cuerpos que mantenían el legado de nuestra historia colonial. Estos cruces de poder que se fueron formando en el contexto colonial, fueron creando, ya en el siglo diecinueve, el imaginario principal desde donde se empezó a escribir el origen y el progreso de las naciones. El mestizaje racial fue el centro creativo de ese imaginario, ya que armonizaba de varias formas muchas de las contradicciones sociales y políticas de las nuevas constituciones. Si por un lado, como señala Anderson, 
la nación imagina la heterogeneidad racial y cultural como un todo homogéneo, al mismo tiempo ese imaginario es el que consolida el saber de este discurso letrado. (Arroyo 12-3; mi énfasis)

Es cierto que estas propuestas terminológicas surgen de un imaginario que ve como equilibrado lo racial y cultural en aras de consolidar las respectivas formaciones de las naciones, excluyendo conflictos que el colonialismo crea en América. Sin embargo, el discurso latinoamericano y caribeño, precisamente por su formación desde lo incierto e idealizante, apunta a que dichos conceptos no deben considerarse como una resolución armónica de los elementos conflictivos, sino que requieren de una interpretación del conjunto de estas ideas.

Así, según las inevitables correspondencias que conllevan estos conceptos, surge un espacio de evidente tensión que ulteriormente simboliza sus contradicciones ${ }^{69}$ Ese lugar muestra la heterogeneidad dilucidada por Cornejo Polar, que sirve "para interpretar fenómenos caracterizados por la asimetría y el conflicto en el contacto de culturas, como lo son los procesos que resultan de la expansión colonial” (Weinberg 39). Contrario a lo que la crítica señala, la ‘mixturación’ no infiere que sus procesos se detienen. El lector, al analizar la noción de transculturación comprende que su dinámica es constante. Es decir, “...ninguna de las categorías mencionadas resuelve la totalidad de la problemática que suscita y todas ellas se instalan en el espacio epistemológico que -inevitablemente- es distante y distinto" (Cornejo Polar, "Mestizaje..." 8). Además, "Si esta pluralidad no deja nunca de ser conflictiva, es también y con mayor intensidad espléndidamente enriquecedora” (Cornejo Polar, "El indigenismo...” 21).

De hecho, no es que la transculturación suponga una solución definitiva de la totalidad de los fenómenos culturales dados en América; más bien inscribe una epistemología metafórica que, como tal, no es concluyente. Al ver dichos conceptos como simbologías y conexiones 
alegóricas, la intención totalizante forma parte de la metáfora misma, expresa la cultura como portadora de dinámicas abarcadoras, mas no absolutas. Cada lector redefine dichos términos y los transforma en cada una de sus interpretaciones ad infinitum. Incluso, el mismo Cornejo Polar nota que ciertamente se trata de entramados figurativos, pues afirma que, “...en el fondo la relación entre epistemología crítica y producción estética” puede ser “inevitablemente metafórica” (“Mestizaje...” 9). Estas correlaciones son representaciones de la cultura de América y el Caribe, y sirven de propuestas teóricas que plantean gnoseologías culturales en un plano estético. Por lo tanto, como metáforas, éstas se intercambian y modifican constantemente..$^{70}$

\section{Contrapunteo: négritude y transculturación}

Este trabajo adopta una dinámica contrapuntística como lo hace Ortiz para establecer así un diálogo entre la négritude y la transculturación. De esta manera, estos razonamientos advienen a partir de un desplazamiento

dialógico y acéntrico en cuyo pluralismo de voces y de ritmos no sólo se dejan escuchar las más variadas disciplinas y las ideologías más irreconocibles, sino también enunciados que corresponden a dos formas muy diferentes de conocimiento, de saber. [...] [Ésta es] la forma más representativa de lo caribeño. (Benítez Rojo 185)

Tanto négritude como transculturación crean nexos de relaciones de poder apoyándose en nociones de raza. Los enlaces que Contrapunteo... establece de los productos del tabaco y el azúcar representan una disposición comparable al vínculo que existe entre las creaciones conceptuales de Césaire y de Ortiz. Éstas son “voces que provienen de distintos centros de emisión, de distintos momentos y discursos, y que coexisten una junto a la otra en una relación compleja y crítica, imposible de clarificar del todo” (Benítez Rojo 205). Ambas 
metáforas demarcan la cultura caribeña, no como una definición tajante y fija sobre las razas, sino como planteamientos de consciencia ideológica; “contiene[n] una problemática que no es de carácter puramente racial, sino que significa asumir una postura en la que existe un elemento ideológico que resolver” (Ferrada 6).

Aquí, la primera voz del contrapunto es la négritude, que establece una concientización que presupone la cultura del negro como modelo caribeño. La transculturación, la segunda voz, perfila una evolución y transformación de la concepción inicial césairiana; responde a un carácter polifónico y permite delimitar la idea de representar una estructura y utilidad cultural a través de modelos epistemológicos. El modo en que la négritude y la transculturación concuerdan es contrapuntístico, ya que implica una "Concordancia armoniosa de voces contrapuestas” (RAE contrapunto; mi énfasis). Sin embargo, el contrapunto que acentúa Ortiz es el guajiro, es decir, se trata de una concordancia que no es del todo armoniosa.

Ahora bien, la armonía señalada representa la parte de la metáfora que establece vínculos de unidad en lo heterogéneo. Esto es, una adhesión a partir de una "Composición que gira sobre un tema y su contrapunto, repetidos con cierto artificio por diferentes tonos” (RAE fuga musical). Entonces, los ensayos de estos caribeños, sus variadas voces, "no sólo se enfrentan una a la otra, sino que también se superponen una sobre la otra y a la vez se despliegan una tras la otra, paralelamente, interactuando entre sí en una fuga perpetua” (Benítez Rojo 203). La forma de fuga, dilucidada por los valores metafóricos de las propuestas césairiana y orticiana, permite que estos trabajos se complementen diacrónicamente, en un sentido “de interdependencia mutua que recuerda la complejidad de las relaciones de poder. En [este] ejemplo de fuga... tal relación sugiere un interplay económico-social de carácter genealógico” (204). Del mismo modo que Benítez Rojo señala esta dinámica, dentro de la fuga, en cuanto al tabaco y el azúcar, sucede igual con los 
conceptos négritude y transculturación: "ninguno de ellos es una unidad irreductible dentro del contrapunto; forman entre sí un conjunto armónico... se despliegan, oponiéndose, aliándose, yuxtaponiéndose y persiguiéndose,... siempre arbitrario en el género de fuga” (205).

Es cierto que la definición antedicha del contrapunto es una alusión de lo armonioso, pero esto no está limitado a una concordancia total entre las voces que la forman, sino que, según sean interpretadas, la presentación de los diferentes artificios e inflexiones va a marcar expresiones discrepantes de dicha armonía. De acuerdo a lo que Wolfgang Iser afirma en su artículo respecto al "Proceso de lectura”,

Todo texto leído produce un coste en la estructura contrapuntística de nuestra persona. Ello quiere decir que la relación que organiza el lector entre el tema y su horizonte de experiencias adquiere una expresión diferente en cada momento. El tema del texto no moviliza más que algunas de nuestras disposiciones y concepciones, y por eso, según sea el texto, el horizonte virtual de nuestras orientaciones se constituye en otro mundo. (163-4)

Por lo tanto, las dilucidaciones de los lectores crean “otros mundos” acerca de estas nociones caribeñas. La forma contrapuntística que adopta este trabajo permite interpretar ambos textos como modelos que constituyen distintas formas de resistencias culturales en el Caribe (desde las creencias aborígenes, europeas y africanas). Con el concepto de négritude como primera parte del contrapunto y con transculturación como voz consecutiva, se establece un patrón de fuga o de réplicas entre ambas propuestas. ${ }^{71}$

Estas creaciones metafóricas son procesos que reconocen y participan del proyecto asimilador de la colonización, ya contraponiéndolo o bien repelándolo. Así, ambos autores muestran sus intereses sociales a través de formas estéticas. Estas epistemologías culturales 
dan comienzo (sin olvidar sus precedentes) a un correlato dialéctico entre las imposiciones del colonialismo que viven los antillanos y las formas de producción de la cultura que eventualmente emerge en el Caribe. En un proceso complementario y diacrónico, la transculturación es un dictamen interdependiente de la négritude.

En el concepto césairiano, advierte René Depestre, hay una revaloración cultural del negro frente a la concepción que el coloniaje crea:

la negritud, en su mejor acepción, fue la operación cultural por la que los intelectuales de África y la de las dos Américas tomaron conciencia de la validez y de la originalidad de las culturas negroafricanas, del valor estético de la raza negra y de la capacidad respectiva de su pueblo para ejercer su derecho a la iniciativa histórica que la colonización había suprimido completamente. (39)

Con similar propósito, Césaire debate la supresión colonizadora que devalúa al negro y Ortiz reconoce la necesidad de cambiar esa visión que se ancla en lo racial. Sobre esto, éste último indica “...que se enmascaran con esos antifaces calificados de razas,... que no son sino falsas figuraciones que sólo existen en las apariencias de la fantasía”. ${ }^{72}$ Según demuestra Arroyo, "Este trance es una forma de crear una visión trascendental de la raza, y da a su vez la metáfora para ‘escapar’ simbólicamente de ese cuerpo negro” (28). Aquí está presente la idea de una separación o desprendimiento, de un deshacerse de la ideología negativa que el mundo europeo inserta en la mentalidad de los habitantes de los países colonizados. ${ }^{73}$

Nótese que ya desde Martí existe esta renunciación a la forma preestablecida de definir las razas y culturas. Éste, igual que Césaire y Ortiz (entre otros estudiosos como Gilberto Freyre $^{74}$ ), insta a cambiar esta mirada: 
Si para José Martí, a fines de siglo, utilizar el término 'razas’ era hablar de ‘culturas', en el caso de Gilberto Freyre y Fernando Ortiz en la segunda década del siglo veinte, la ‘cultura’ se relativiza separándose del concepto de raza. Aunque son proyectos que se derivan del positivismo científico (al que pertenece por varios años Fernando Ortiz), ambos parten de dos preocupaciones principales: ¿cómo integrar las poblaciones negras al discurso nacional? (Arroyo 14; mi énfasis)

En el caso de négritude, la idea de configurar la nación difiere de la de Ortiz. ${ }^{75}$ No obstante, aun ambas nociones apuntan lo racial como el elemento que define el punto de partida que escinde las ideas preestablecidas de la metrópolis. Sin embargo, aunque los términos de ambos crean yuxtaposiciones lingüísticas e ideológicas a través de tropos, no necesariamente logran esa separación entre lo cultural y lo racial. Esto es, por un lado el concepto de négritude implica en sí mismo lo racial, la identificación del negro en contraste con el poder hegemónico asimilador y la lucha de resistencia que parte y se apoya en el concepto de razas. Por otro lado, el juego contrapuntístico que utiliza Ortiz a lo largo de todo su libro está estrictamente ligado con la concepción racial; las metáforas se sostienen en la plataforma antagónica de lo negro y lo blanco, formando así el soporte alegórico que determina la transculturación. Para validar la idea cultural caribeña en el segundo cuarto del siglo XX, estos pensadores toman elementos contrarios a los del poder colonizador. Por eso la disociación de las razas de lo cultural es inviable. ${ }^{76}$

\section{Marx en Césaire y en Ortiz}

Las relaciones de poder son centrales en la formación de los conceptos de Césaire y de Ortiz. A partir de la noción de raza como base en las propuestas de ambos escritores, éstos evalúan los nexos de dominación en el sistema colonial y la asimilación que impone este 
régimen. Tanto négritude como transculturación son configuraciones ideológicas que surgen como consecuencia de las producciones capitalistas de la hegemonía. Las correlaciones creadas por las estructuras de poder en el colonialismo abren una brecha para negociaciones y resistencias entre las distintas partes.

Ahora bien, los vínculos de poder en cualquier sistema conciben espacios que llevan a la negociación, es decir, lugares abiertos que permiten la toma de consciencia y, con ésta, la posibilidad de intercambiar quien porta el poder. Henri Lefebvre en The Production of Space aclara que, "(Social) space is a (social) product. ... the space thus produced also serves as a tool of thought and of action; that in addition to being a means of production it is also a means of control, and hence of domination, of power" (Lefebvre 26; mi énfasis). Las herramientas de pensamiento y de acción posibilitadas por el espacio que procede a partir de las relaciones de poder, llevan a nuevas creaciones, aquí de términos culturales que se resisten y a la vez se apoyan en el sistema. Ese emplazamiento en el Caribe marca "los procesos de hibridación, las desterritorializaciones y reterritorializaciones culturales, y constituye el lugar de negociación entre lo ajeno y lo propio” (De Toro 17). Las negociaciones facilitadas por estas dinámicas de poder son multidireccionales y permiten constituir “...estrategias diferentes (pero prontas a caer la una en la otra) para integrar las relaciones de fuerza desequilibradas, heterogéneas, inestables, tensas” (Foucault 56).

En esta esfera se ponen de relieve "objetos y medios culturales [que] están a disposición” y que permiten la recodificación. Se trata de una simbiosis, de "espacios donde se juntan y separan los elementos, donde las identidades y el sujeto se fragmentan o se diversifican, en los que la memoria se inscribe, el pasado se reescribe y el presente se escribe” (De Toro 17). Michel Foucault agrega: 
[En] El análisis en términos de poder... hay que comprender, primero, la multiplicidad de las relaciones de fuerza inmanentes y propias del dominio en que se ejercen, y que son constitutivas de su organización; el juego que por medio de luchas y enfrentamientos incesantes las trasforma, las refuerza, las invierte; los apoyos que dichas relaciones de fuerza encuentran las unas en las otras, de modo que formen cadena o sistema, o, al contrario, los corrimientos, las contradicciones que aíslan a unas de otras; las estrategias, por último, que las tornan efectivas, y cuyo dibujo general o cristalización institucional toma forma en los aparatos estatales, en la formulación de la ley, en las hegemonías sociales. (Foucault 55)

De acuerdo a lo señalado, al existir nexos de poderes, germinan transformaciones, intercambios, desplazamientos, que, en fin, son parte empírica de la sociedad inserta en dicho espacio. Al igual que Lefebvre, que indica que este lugar es un producto social y al mismo tiempo productor (de control y de poder), Foucault afirma que "las relaciones de poder son inmanentes y desempeñan un papel directamente productor” (56). ${ }^{77}$ El rol de esta producción social está enlazado con las propuestas marxistas acerca de las elaboraciones del sistema capitalista.

El vínculo con Karl Marx surge ya que su trabajo no trata solo los productos o las cosas tangibles, sino que constituye igualmente esferas abstractas e ideológicas de la sociedad. Los conceptos marxistas (y hegelianos) tienden a desdoblarse, “de un lado está la producción de productos: las cosas, los bienes, las mercancías, y del otro lado la producción de las obras: las ideas, los conocimientos, las ideologías e incluso las instituciones o las obras de arte” (Lefebvre 219). La teoría de Marx, por estos desdoblamientos, ilustra las posibilidades que provee el espacio estratégico formado por las relaciones de poder. Aquí, el lugar que hace posible la elaboración de pensamientos es paralelo a la dinámica que surge en las relaciones capitalistas de producción. En Capital. Vol. 1., Marx indica que, "sólo a través de las relaciones que el acto de intercambio establece entre los productos, y a través de su mediación, entre los productores”78 es que se posibilitan los modos de producción del capital. 
Con esto, "las máscaras que en lo económico asumen las personas, no son más que personificaciones de las relaciones económicas como portadoras de las cuales dichas personas se enfrentan mutuamente” (Marx 104).

Así, los existentes enmascaramientos en las nociones creadas por Césaire y Ortiz se apoderan de elementos físicos (raciales) y se trasmutan en ámbitos abstractos. Utilizando la teoría marxista sobre las relaciones económicas y sus consecuencias en los distintos grupos sociales, puede denotarse también que a partir de las "características externas como el color de la piel” se llega a un "lugar de conflicto que debe ser negociado" (De Toro 22). ${ }^{79}$ Tanto para Marx, como para estos autores caribeños, el sistema crea emplazamientos de tomas de consciencia, manipulando el poder, en un nivel tangencial o ideológico (Lefebvre). Es por esto que, en ese espacio establecido por las dinámicas de la relación de la producción dentro del colonialismo, “La 'identidad', lo 'auténtico' se negocian hoy en día en la diversidad de las orillas y en los puntos-cruces del encuentro de culturas (y no a través de oposiciones, sino por medio de operadores...) ...un 'intermedio', en un espacio extra-territorial” (De Toro 20; mi énfasis). Por lo tanto, las confluencias culturales que necesariamente se dan bajo el sistema colonial, tranzan identidades y confunden la autenticidad de las fuentes que operan e intermedian en el espacio que ese mismo régimen implanta. Por esta razón, este lugar se presta, sin duda, a inversiones que llevan a, "La fisura, la negociación cotidiana [que] se transforma en el signo de identidad” (De Toro 20), “ya que condicionan de forma decisiva la producción y recepción de productos culturales, su nivel pragmático o semántico” (21).

De acuerdo a lo indicado, Césaire, en “Négreries” y en “Conscience raciale”, parte de las ideas marxistas mencionadas. En un marco retórico, la propuesta inicial del término négritude, "It is embedded in and indebted to a heavily Marxist, revolutionary discourse ... In "Nègreries" Marxism surrounds and defines the problem of race, as an issue of 'social 
revolution' and capitalism, even as race struggles to assert itself on its own terms” (Miller 744). La creación del concepto césairiano propone una toma de consciencia a partir del elemento racial, aun su permanente condición de lucha. La correlación con la ortodoxia marxista en cuestión surge del debate de Césaire contra el capitalismo y sus relaciones de poder que oprimen al negro o al proletariado paralelamente. Sobre esto, el ensayo del autor martiniqués analizado por Miller dice: “... Pourtant, c’est bien là le tour de force que veulent entreprendre nos révolutionnaires nègres lorsqu'ils demandent au nègre de se révolter contre le capitalisme qui l’opprime” (744-5). Además, las adaptaciones de Césaire a las ideas marxistas no se detienen, pues,

Readers of Marx will see how Césaire adopts and adapts Marxist terminology. As Raisa Rexer puts it, “By replacing 'proletariat’ with 'nègre,' and 'class’ with 'race,' Césaire has made Marx discuss race; indeed, placed race at the very heart of Marxism's most fundamental premises about the relationship of material reality to immaterial realities like consciousness and ideology. (Miller 745)

Sustentándose en la retórica marxista, Césaire instaura la identidad cultural del negro. El escritor caribeño cuestiona la incitación de Marx acerca de la clase social del proletariado (Miller 745) y, de cierto modo, corrige las ideas de este último sobre la revolución comunista. En su ensayo, Césaire aclara que para incitar al negro (en Marx al proletariado) a revelarse en contra del sistema capitalista creado por el blanco lo más importante es mostrarle el camino para que tome consciencia de sí mismo y su propia legitimidad (745-6). Entonces, no se trata de una oposición al marxismo sino, más bien, un apartado aclaratorio de éste: "Negritude is thus born not in categorical opposition to Marxism or to the idea of a general communist revolution but rather as an engaged corrective to these ideas” (Miller 747). Asimismo, la 
retórica comunista es crucial para la formulación de la négritude, se adhiere parcialmente a ésta para advertir la necesidad que tiene el negro de aprehenderse antes de manifestarse en contra del sistema. De esta forma, “Césaire’s approach here: marxisant, meaning conversant with Marxism but not adhering to all aspects of the philosophy” (748). Dicho de otro modo, la creación del término césairiano dialoga con la teoría marxista, utilizando su discurso, y al mismo tiempo contradice las nociones universalistas y asimilicionista del comunismo: "seeking a path toward change that embraced the particular within the universal. First, the particular had to be defined and defended: hence negritude” (748). Césaire se apoya en las propuestas de Marx y, partiendo de la complexión racial del negro, voltea los parámetros que la cultura hegemónica predispone.

En Ortiz, también en referencia a la argumentación marxista, se utilizan las relaciones de poder dadas en la producción mercantil capitalista para explicar la sociedad que la crea. Éste muestra cómo esas correlaciones del colonialismo ponen de relieve los conflictos de las transacciones de las mercancías dentro de dicho sistema: "Without making reference to Marx, he shows how the appearance of commodities as independent entities... conceals their origins in conflictual relations of production...” (Coronil xxvii).

En su ensayo el pensador cubano, de cierta forma, va un poco mas allá que Césaire. De hecho, Ortiz alegóricamente crea las personificaciones del tabaco y el azúcar, las mercancías principales en el sistema de las relaciones de producción de la isla, convirtiéndolos en entes de poder. ${ }^{80}$ Ambos productos representan autoridad, ya que, "Por supuesto, todo sujeto investido de poder se relaciona de múltiples maneras con los individuos que actúan en función de objeto de poder, y viceversa” (Benítez Rojo 143). Por esta razón, en el espacio caribeño se plasman innumerables formas de expresión cultural, por las dinámicas que las 
relaciones de poder y sus producciones capitalistas instituyen. Precisamente, Benítez Rojo añade ejemplos de estas disposiciones:

Así, las relaciones de poder que en Cuba establece el azúcar fluyen por numerosísimos canales, los cuales configuran una vasta e intrincada red de conexiones sobre la superficie sociocultural al tiempo que establecen formas de dependencia, dominación, subyugación, castigo, control, vigilancia, retribución, educación, explotación, desafío, resistencia, acatamiento, convivencia, rebelión, etc. (Benítez Rojo 143)

Al presentar las trayectorias de dichos productos, Ortiz les adjudica significado a sus formas y sus usos. Por lo tanto, "For that we have to follow the things themselves, for their meanings are inscribed in their forms, their uses, their trajectories. It is only through the analysis of these trajectories that we can interpret the human transactions and calculations that enliven things” (Appadurai 5; mi énfasis). Entonces, el término transculturación es una interpretación de la cosas -las mercancías-, en favor de traslucir las intrincadas conexiones humanas que se dan en esas relaciones de producción. Desde ahí, el autor marca otro espacio dentro del ya creado por el sistema capitalista. Éste ilustra la multiplicidad de significados que estas relaciones de poder desencadenan dentro de los nexos de producción de estos bienes: "Ortiz has shown that they can appear as autonomous agents only because they are in fact social creatures, that is, the products of human interaction within the context of capitalist relations of production” (Coronil xxviii).

Césaire y Ortiz muestran que las ideas de Marx no solo se circunscriben en los lugares que forman dinámicas intelectuales en la cultura europea sino también en las de sus colonias. Es decir, el marxismo presenta “intellectual formations involving not only 'backward' and 'modern' locations of European culture, but also dominant and subaltern perspectives within 
it” (Coronil xlii). Esto ilustra el desdoblamiento que se da en las terminologías marxistas. No se trata únicamente de las mercancías que se producen en el sistema sino también de los intercambios culturales que surgen. Por lo mismo, "From a cultural perspective, the production of commodities is also a cultural and cognitive process: commodities must be not only produced materially as things, but also culturally marked as being a certain kind of thing” (Kopytoff 64).

No obstante, los planteamientos de los procesos culturales y cognitivos que la retórica marxista viabiliza, no desarticulan las ideologías raciales de las propuestas de identidad cultural en el Caribe. Por consiguiente, es improbable que los autores estudiados en este capítulo hagan una separación de lo cultural y lo racial. Sobre esto, Godoy propone acerca del trabajo de Ortiz y el concepto de transculturación, advirtiendo aquí que sucede igual con la négritude de Césaire, que es inminente que "Esos complejísimos fenómenos sociales” pautan la correspondencia de las razas y culturas, “o sea la mezcla de influencias recíprocas de los diferentes grupos humanos entre sí” (Godoy 242). ${ }^{81}$

Por último, hay que subrayar que bajo el régimen del colonialismo europeo además se establecen las dinámicas de la asimilación cultural. La sociedad bajo el capitalismo, a través de las relaciones de poder, utiliza la política asimilicionista para establecer un ‘convenio’ que cosifica a los individuos de la periferia. Al asimilarse un individuo, éste trasmuta en lo que Marx denomina como 'producto de masa'. ${ }^{82}$ Así, esta conversión demuestra la ausencia de control que tiene el asimilado-colonizado frente a las relaciones de producción del sistema. El negro dentro del régimen, al dejarse asimilar, acepta convertirse en mera criatura de la actividad humana. Por lo tanto, en el espacio de negociación que crean las relaciones de poder y que advierten ambos autores con sus términos, el negro puede revertir ese proceso 
asimilativo a través de la toma de consciencia (que le empodera) aun bajo el sistema eurocéntrico del coloniaje.

A modo de cierre, la metáfora de la négritude representa un proceso de aceptación que el negro debe hacer de sí mismo para concertar su cultura. Esta representación metafórica no es la revolución ulterior que Césaire propone. El concepto sirve como herramienta para esa revuelta, para luchar frente a todas las fuerzas que atentan en contra de la riqueza cultural del negro: "Black culture has always resisted any invading force that thought they knew better than Africans" (Garraway 73). Precisamente, Soyinka afirma que el término "Négritude became a weapon”; es esa arma metafórica la que sirve para rescatar y reapropiar la cultura negra. La négritude viabiliza la emancipación del negro colonizado; permite la liberación de la ideología occidental que lo subyuga.

Cuando Césaire llega a París en la década del treinta, éste percibe una nueva realidad que lo confronta con la mirada europea preconcebida. Igualmente, esto le sucede a Ortiz a comienzos de siglo cuando estudia en Italia y en España. ${ }^{83}$ Ambas nociones surgen de un mismo trasfondo histórico, observan y traducen los variados entornos, aunque desde distintas perspectivas. Ambos, aún jóvenes, crean cuestionamientos sobre estas diferentes realidades. Así, “¿Cómo creer, además, que una cosa pueda ser la realidad de otra, o que haya sensaciones trastocables -definitivamente- en otras sensaciones?” (Borges, "La metáfora” 114; mi énfasis) Los tropos que construyen, entonces, posibilitan una verdad en otra: escudriñan los elementos que las conforman, los trastocan, proveyendo varios significados válidos, según las posibles lecturas de las distintas realidades.

Sobre esto, el concepto del autor martiniqués cuestiona,

"What is that reality?" Césaire proceeded then asking. That is indeed the question: is there a content and a substance of the concept of Négritude 
beyond the revolt and the proclamation? In other words, is Négritude mainly a posture of revolt against oppression the manifestation of which is primarily the poetry it produced, or is it a particular philosophy characteristic of a black worldview? (Diagne 3)

La respuesta a ambas preguntas, si hay contenido y substancia en el concepto de négritude y si es particularmente una filosofía del mundo cultural del negro, es sí: todo forma parte del modelo metafórico cultural césairiano. Asimismo sucede con la epistemología orticiana.

La négritude y la transculturación son intrínsecamente "arquetipo[s] o punto[s] de referencia para imitarlo[s] o reproducirlo[s]" que marcan "esquema[s] teórico[s], ..., de un sistema o de una realidad compleja,...” (DRAE modelo). Esto sucede porque los términos trasladan o trastocan "el sentido recto de las voces" (o los parámetros establecidos) "a otro figurado, en virtud de una comparación tácita” (DRAE metáfora). Con esto, la esencia o naturaleza de estos modelos epistemológicos es (re)presentar un "conjunto de modos de vida y costumbres, conocimientos y grado de desarrollo artístico, ... en una época, [y] grupo social” (DRAE cultura), específicamente para el negro. Y como en una especie de caja china, dentro del grupo social del negro, el del antillano.

La construcción de metáforas culturales en el Caribe, a partir de Césaire y Ortiz, entre otros, es una dinámica cambiante. Las formas de pensar van evolucionando en coincidencia con los eventos históricos que sobrevienen. Así, la producción cultural y lingüística responde de acuerdo a estas transformaciones de la sociedad. Cuando finaliza el periodo de entreguerras, con el surgimiento de la Segunda Guerra Mundial, los intereses cambian y producen otras expresiones que simbolizan esas nuevas ideas. De este modo, los términos négritude y transculturación son una anticipación de las próximas metáforas que se 
desarrollan en el Caribe: contrapunteos culturales que definen y representan la identidad antillana.

Contraponer los elementos de la cultura dominante con los de la periférica es parte de la reformación conceptual epistémica caribeña para los autores analizados en estos dos primeros capítulos. Ambas metáforas advierten la imposibilidad que existe en las Antillas de separar lo cultural de lo racial, lo social-histórico de los diferentes grupos humanos. Por esta razón, "Para lograr su objetivo[,] Ortiz [y Césaire] apela[n] continuamente no sólo a la necesidad de conocer su historia y de aceptar su pasado como parte integrante de la cultura y la sociedad actual cubana [y martiniquesa], sino también a la necesidad de enseñar y educar a los ciudadanos” (Naranjo-Orovio 157). Ciertamente, ambos autores enuncian en sus ensayos su sentido de responsabilidad. ${ }^{84}$ Éstos buscan tomar control, en cuanto a modificar las visiones preestablecidas en sus respectivos Caribes, sirviendo como maestros para los negros y los mestizos, o bien transculturados. ${ }^{85}$ Los dos conceptos instan a la sociedad antillana a identificarse como parte de una cultura capaz de concebir su nación similar a la hegemónicaimaginada.

Igualmente, existe un proceso de transición en el lugar en el que chocan dos o más culturas. Ahí surge el espacio para las transformaciones que crean nuevos términos para nombrar los fenómenos resultantes. Aquí, uno de los autores busca cortar el proceso transitivo de la cultura (en contra de la asimilación cultural) -négritude- y el otro transculturación-, en aparente contradicción, adopta ese proceso asimilativo. Sin embargo, en lugar de contradecirse, estos conceptos se complementan sincrónica y diacrónicamente, pues, tanto Césaire como Ortiz crean y proponen metáforas para representar los cambios culturales que se encuentran en constante movimiento. A través de sus propuestas, ambos neologismos, partiendo desde la base etimológica y morfológica de los vocablos, logran que 
exista una adscripción constante y consciente de, al menos, una de las partes que conforman la cultura caribeña.

En los siguientes capítulos de este trabajo se sigue la evolución de las creaciones metafóricas tomando en cuenta estos procesos de transición en el espacio cultural del Caribe. Cada uno de los autores estudiados muestran la complejidad que existe al momento de establecer que, efectivamente, la cultura sirve como metáfora de las distintas relaciones de poder que abarcan globalmente las sociedades humanas. 


\section{Capítulo 3:}

\section{La historia como metáfora cultural caribeña}

“...it is in the solitude of the cell that he [Calibán] gets a chance, free from the indulgence of his followers, to think things out (George Lamming 114).

\section{La metáfora de la historia en "La historia me absolverá"}

"La historia me absolverá” es un ensayo de Fidel Castro pronunciado con el fin de autodefenderse ante el Tribunal de Urgencia de Santiago de Cuba el 16 de octubre de $1953 .{ }^{86}$ Es un alegato jurídico que tiene la intención inicial de explicar las razones del asalto al Cuartel Moncada llevado a cabo el 26 de julio de ese mismo año. El texto dado a conocer es una reconstrucción de la exposición original presentada frente a dicha audiencia. El lugar en el que se crea este escrito es la celda en la que Castro pasa su encierro carcelario. Mientras éste permanece en prisión, no solo concibe, redacta y, luego, reconstruye sus palabras sino que también emprende su distribución. Así, difunde su proyecto al pueblo a pesar de su cautiverio. Marta Harnecker afirma en Fidel, la estrategia política de la victoria (2001), que Castro reconoce que esta difusión es determinante para el éxito de la revolución; “ahí está contenido el programa y la ideología” del grupo de insurrectos, sin los cuales “es imposible en pensar en nada grande... [es además] un programa valiente y avanzado que constituía, por sí mismo, parte esencial de la estrategia revolucionaria” a gran escala (52). ${ }^{87}$

De esta forma, el texto opera en varios niveles. Primero, tiene la intención de servir de defensa jurídica para el acusado y, posteriormente, de propaganda para el movimiento de las masas. El objetivo de comunicar al pueblo las reflexiones del ensayo era obtener el favor de la opinión pública, estableciendo un nexo entre el reo y la sociedad cubana, y viceversa. Castro entonces transmite su ideología para conseguir el respaldo y confianza de la 
población. Con esto, el joven revolucionario da los primeros pasos para movilizar la ciudadanía al dar a conocer su discurso por escrito en todo el país. Así, hay un intento por alcanzar la amnistía de los presos políticos, entre los que estaban los que habían combatido en el asalto al Cuartel Moncada. Además, al propagar el discurso también se exponían los abusos de Batista.

El ensayo castrista ilustra valores contrarios a los de la dictadura. Sus expresiones responden al silencio que el régimen había impuesto a los insurrectos con el encierro. Al mismo tiempo, hay una "preocupación por dar una imagen de absoluta honradez, [y] de dedicación a la defensa de los intereses del pueblo,...” (Harnecker 61). Con esto, Castro se presenta como un ente heroico que busca amparar la sociedad cubana. Por consiguiente, de la imagen del individuo enclaustrado, el texto pasa a la visión cabal de la comunidad. Esto permite señalar a la masa como víctima de los abusos políticos del sistema y no exclusivamente al grupo de insurgentes. Al incorporar lo plural en un único individuo se transfiere la noción de lo real a lo metafórico, de lo singular a lo múltiple y, asimismo, a la inversa. De este modo, el autor comienza a concebirse como entidad multifacética que se manifiesta según las nuevas aspiraciones y luchas que emprende el pueblo. Hay aquí una idiosincrasia individualizada, no obstante, proyectada hacia una conciencia colectiva: “...hoy más que una fuerza real, somos una idea, un símbolo, una gran fuerza en potencia... [considerada] la verdadera revolución” (63). ${ }^{88}$

Entre los símbolos que se encuentran presentes en el discurso de Castro están, por ejemplo, la imagen de la cárcel. En particular, ésta funciona como metáfora del encierro de los ideales y, por consiguiente, señala un enclaustramiento de la libertad de la ciudadanía, tanto política como cultural; “...mostrando ante la faz de la nación del mundo la infinita desgracia de este pueblo, que está sufriendo la opresión más cruel e inhumana de toda su historia” (Castro 
192). Así las cosas, el texto castrista se lee a través de tropos. Estos aluden, más allá de pedir la libertad y defensa del acusado, a enfrentamientos directos y figurados en contra de la dictadura, en defensa de la nación.

Por lo tanto, a partir del evento del Moncada, Castro plasma una gama de elementos que simbolizan sus ideologías. Esto, debido a que demostró ser "el opositor con mayor posibilidad en contra de Batista y su gobierno. Aunque el objetivo del Moncada no se logró, al menos se consiguió demostrar que... [atrajo a] los demás jóvenes. ... [Así,] El Moncada [y este ensayo] termina[n] una etapa y comienza[n] otra del proceso insurreccional cubano" (López-Ávalos 91). Los valores aludidos sirven de tropos que apelan a la unión de las masas como base de la lucha. “[A] partir de estos hechos se irán conformando una serie de valores que darán cohesión a sus miembros. Varios ... rasgos característicos en este proceso; ... [son] la fidelidad de la figura del líder, ... y la aceptación de los valores políticos” (LópezÁvalos 92). El texto tenía como propósito fundamental, "generar un gran movimiento de masas a partir de la identificación de ciertos ideales y aspiraciones” que forman parte de la sociedad y que conviene condensarlos “en un programa político dirigido al ... combate” (86). Por eso la imagen del pueblo es imprescindible para observar la historia de ese proceso revolucionario en Cuba.

Por lo tanto, las imágenes provistas urden un ideario que funciona para el fortalecimiento de una identidad cultural. Esto revela una tendencia a desprenderse de un pasado hegemónico colonial, el que viene de afuera (España y Estados Unidos) y que trama establecerse en las entrañas de la sociedad cubana desde un adentro disfrazado de poder auténtico. Así, “La historia me absolverá” es una respuesta ideológica a ese pasado colonial que representa el presente dictatorial. El escrito evoca un futuro liberado del sistema, tanto el anterior como el vigente. Castro apunta además el papel que los sucesos históricos ocuparon 
para la insurrección, indica que, “...no puede haber revolución, en primer lugar, si no hay circunstancias objetivas que en un momento histórico dado faciliten y hagan posible la revolución” (Castro 30). ${ }^{89}$

Estructura del ensayo

La estructura interna de la autodefensa escrita por Castro no es cronológica, sino que obedece a una composición cíclica. Según Carlos Maldonado en “Teoría de la historia, filosofía de la historia y complejidad”, un ‘texto’ asume el carácter de una reflexión sobre la historia a medida que representa un cúmulo de información. Esta discontinuidad temporal marca, por su disposición, un proceso mediante el cual se ganan distintos grados de libertad con respecto al presente. La historia traspasa lo cultural y la sociedad en general: es un antes y un después; un más allá (Maldonado 43). Lo cíclico, tanto en la concepción de la historia como en la forma que adopta el discurso de Castro, muestra un sistema abierto que permite el regreso constante e indefinido a los hechos presentados a través de la subjetividad de quien expone. ${ }^{90}$ De esta manera, se trasluce el carácter figurado del ensayo: su estructura simboliza una apertura de los hechos y enlaza un evento individual (el ataque al Moncada) con lo repetitivo (eventos históricos del pasado) y, por ende, con lo plural-colectivo (la cultura).

La organización del texto, el sentido que la historia toma en éste e igualmente el uso de metáforas, muestran indeterminación, incertidumbre y posibilidades (Maldonado 47). En particular, esto se ve cuando el autor dice que la “justicia está enferma... y está presa” (Castro 196), ilustrando el daño y encierro (referencia también a la reclusión de Castro) de los valores que el pueblo entiende como positivos. De ahí que queden implícitas las posibilidades de liberar la figura de la justicia (en la que también se ven repercusiones metafóricas). Otro ejemplo del uso de tropos se observa cuando Castro advierte que quiere “tener el campo limpio de minucias para cuando llegue la hora de tocar el degüello contra la 
mentira...” (Castro 11). Aquí, el vocabulario de guerra-destrucción está presente, marca la imagen del revolucionario caribeño que se adhiere a la tradición histórica a través del sujeto que es capaz de enfrentar dicho degüello, es decir, quien pueda atacar la falsedad de la dictadura. La apertura del sistema adoptado en el escrito provee, por lo tanto, una naturaleza maleable que permite construir, reconstruir, de-construir e incluso destruir lo narrado (si por alguna razón no resulta coherente o congruente) (Bloch). Por eso, la historia y la organización del texto deben igualmente leerse en un nivel figurado.

Considerando la naturaleza cíclica y sincrónica de la estructura, el texto puede dividirse y desglosarse de la siguiente manera:

a. La condición presente: exposición de los hechos

El comienzo del ensayo presenta las razones por las que el acusado está preso y el por qué de su declaración. Se inicia la retórica de persuasión que adopta el declarante a través del uso de epítetos que se extienden a lo largo del texto. ${ }^{91}$ La voz del ensayo inicia con la tercera persona singular como punto de enunciación. Esto muestra un alejamiento de su posición de prisionero y un acercamiento a su lugar de abogado. Casi inmediatamente, el escritor pasa a la primera persona singular para confesar que toma su "propia defensa” ante el tribunal como una acción obligada por las circunstancias. Luego, por un momento, el exponente retoma en una sola oración la voz de la tercera persona, para de inmediato regresar a la primera. El resto del ensayo es expresado desde esta última perspectiva, aunque cabe señalar que la segunda persona plural aparece ocasionalmente para aludir a quienes se dirige, es decir, a los magistrados del Tribunal de Urgencia. Esto sirve de recordatorio del lugar en el que se ubica el acusado, su situación y, por consiguiente, el espacio en el que surge la escritura. ${ }^{92}$

En un primer plano, Castro se denomina como un ser herido, no como consecuencia de un ataque contra sí, sino en contra de su nación. Éste declara que, “...sólo quien haya sido 
herido tan hondo, y haya visto tan desamparada la patria y envilecida la justicia, puede hablar en una ocasión como ésta con palabras que sean sangre del corazón y entrañas de la verdad” (Castro 189). Aquí, igualmente aborda el tema, que se advierte a lo largo de todo el ensayo, del mal que afecta a la justicia. Además, el exponente explica por qué toma el papel de abogado a pesar de habérsele asignado un defensor, Jorge Pagliery, pues, "No lo dejaron, sin embargo, desempeñar su misión: ... Fue entonces cuando se decidió que, haciendo uso de mi condición de abogado, asumiese yo mismo mi propia defensa” (189-90). En esta primera parte del escrito, Castro busca establecer una identificación de sí con las masas. Para éste, se trata de una dinámica que surge, “cuando los hombres llevan en la mente un mismo ideal, [pues] nada puede incomunicarlos, ni las paredes de una cárcel, ni la tierra de los cementerios, porque una misma alma, una misma idea, una misma conciencia y dignidad los alienta a todos” (Castro 191-2; mi énfasis). Así, uniendo lo individual con lo colectivo, a lo largo del texto se expresan calificativos que pueden intercambiarse entre varios sujetos. Es decir, epítetos que describen inicialmente a un individuo, pero luego funcionan para referirse a otros.

En fin, desde la apertura del ensayo se observan distintas vías para persuadir a los magistrados. De igual forma existe una intención propagandística que augura el acceso al texto fuera de la sala del tribunal-hospital. Castro convenientemente expresa una retórica que busca convencer al receptor. Quien lee entre líneas reconoce casi de inmediato que no se trata de una simple defensa legal. Incluso, el tono del trabajo señala una actitud redentora procurando liberar de toda culpa a la sociedad cubana (incluyendo una exoneración de los miembros del tribunal y los militares) con la excepción del régimen dictatorial y de los que actúan deliberadamente a su favor. ${ }^{93}$ 
b. Eventos del pasado inmediato: alrededor del Moncada

El ensayo muestra parte de la historia política que repercute directamente con el momento por el cual se redacta. Hay una rememoración que busca aclarar los hechos en torno al asalto al Cuartel Moncada. También se presentan algunos nombres de los perecidos en dicho ataque. Con esto, hay un intento de recuperación del pasado y de reapropiación de la narración histórica en la que simultáneamente Castro opta por insertarse en ésta. En la crónica descrita se utilizan adjetivos que funcionan para lograr los propósitos antes advertidos. Por ejemplo, la invasión al cuartel es vista como una gran gesta heroica: "En Oriente se respira todavía el aire de la epopeya gloriosa y, al amanecer, cuando los gallos cantan como clarines que tocan diana llamando a los soldados y el sol se eleva radiante sobre las empinadas montañas, cada día parece que va a ser otra vez el de Yara o el de Baire”94 (Castro 210). De esta manera, el acto del grupo de insurrectos en el Moncada queda enlazado por Castro con el devenir histórico de la lucha de independencia cubana que inicia en el siglo XIX.

c. Hechos de la historia: entrelace de la dictadura batistiana con alusiones literarias

El autor, además de ampararse en la presentación de los hechos o de las alusiones históricas que para él repercuten en su presente, igualmente cita fuentes literarias que anclan su discurso con una tradición cultural universal. Comienza con las crónicas históricas de las matanzas de los aborígenes americanos, añade la mención de los ataques de los piratas y llega ulteriormente a narrar eventos de las guerras de independencia. Luego, cierra esta sucesión de eventos con "los horrores del machadato". 95 Además, el autor intercala citas de Balzac y de Dante durante la presentación y mención de estas condiciones y descripciones. 
d. El plan político: reformas y críticas al sistema

El plan político de Castro está ideado aquí. Es una reforma que abarca la estrategia y manejo de la industrialización, el uso de las tierras (agricultura) y la vivienda. Estos planes buscan posibilitar un mayor enfoque hacia la cura de enfermedades, al desarrollo de un

programa de educación, etc. Éste indica además que su alegato jurídico es una defensa de la Constitución de 1940:

“La Historia me absolverá” es un análisis multilateral de aquella república, de aquel momento, en el que él va analizando sector social por sector, y problema por problema, y amplifica su visión crítica hacia todo el espectro económico. En síntesis, Fidel adopta como principal referente la Constitución de 1940 para la solución de muchas de las situaciones por resolver...”. (Mencía)

También, se alude nuevamente a reconocidas referencias literarias para validar las declaraciones en contra de Batista. Así, menciona otra vez a Dante para definir los manejos políticos batistianos: "las manos criminales que rigen los destinos de Cuba habían escrito para los prisioneros a la entrada de aquel antro de muerte, la inscripción del infierno [dantesco]: 'Dejad toda esperanza'” (Castro 225). Luego añade que, “Dante dividió su infierno en nueve círculos... ...dilema el que tendrían los demonios para buscar un sitio adecuado al alma de este hombre [Batista]... ¡ $\ldots$ si este hombre tuviera alma!” (226). La crítica contra Batista resalta aquí el carácter anti-heroico que encarna éste. En particular, si el dictador carece de alma no tiene las cualidades del héroe (contrario a Castro).

e. La vuelta: exposición de los hechos y más crítica contra Batista

En esta parte hay un regreso a otros eventos relacionados directamente con las consecuencias del ataque al Cuartel Moncada. Se alude a las repercusiones que tuvo el 
gobierno en contra de varios activistas que se sublevaron al otro lado de la isla el mismo día del asalto. Con esto, hay menciones específicas de más personas heridas y torturadas. De manera que se inmortalicen (a través de la palabra hablada-escrita) los combatientes. Sobre esto, se muestran los actos de insurrección como heroicos. Esto, con el fin de trazar los hechos como parte de la épica histórica de la sociedad cubana.

f. La validación histórica: citas de textos del pasado remoto hasta la modernidad

Para darle aprobación a la defensa escrita, el autor utiliza referencias a textos antiguos, bíblicos $^{96}$ y seculares. Con esto, existe una ratificación del presente del escritor a través de textos de la antigüedad, del medioevo y de la época moderna. También alude a José Martí y a otros próceres de la historia cubana; busca validarse, desde el comienzo del discurso, advirtiendo que trae consigo, “en el corazón las doctrinas del Maestro y en el pensamiento las nobles ideas de todos los hombres que han defendido la libertad de los pueblos” (Castro 196). Asegura además que son todos estos hombres del pasado los que aportan y certifican sus actos y, así, su propia imagen. Por lo tanto, las alusiones de figuras históricas y literarias sirven para identificar a Cuba con distintos contextos y con otras naciones.

Del mismo modo, Batista es comparado con eventos y personajes históricos contrarios a los que sirven para definir el carácter de Castro. Por ejemplo, hay una equiparación de Batista con Napoleón, específicamente con su venta del vasto territorio de Louisiana a los Estados Unidos. ${ }^{97}$ Luego, se resaltan acontecimientos anteriores, asemejando al dictador cubano con Herodes y la matanza de los niños. Estas alusiones bíblicas sirven para dar legitimidad a su reclamo. Castro arguye, "He puesto ejemplos extremos para que se comprenda mejor lo triste y humillante que es nuestra situación” (246). Así se busca invalidar el régimen de Batista a través de la mención de una serie de sucesos históricos que se remontan a la antigüedad literaria hasta llegar a la historia insurreccional del país: 
El programa aludido por Castro -conocido posteriormente como "El Manifiesto del Moncada a la Nación”- es un documento de recuento y declaración de principios, donde se enuncia un programa de reconstrucción nacional. Resulta interesante observar cómo, por primera vez, el movimiento insurreccional se considera como parte de una larga cadena histórica de una 'revolución inacabada': iniciada por las fuerzas independentistas en 1868, continuada por Martí en 1895, y actualizada por Guiteras y Chibás en la etapa republicana, donde el golpe de marzo ha sumido en el caos a la nación. El 'Manifiesto' establece la ruptura generacional entre una clase política claudicante frente a una dictadura y la 'juventud del Centenario', que no mantiene otro anhelo más que honrar con sacrificio el triunfo del sueño irrealizado de Martí. (López-Ávalos 87)

Otro ejemplo que interesa son las alusiones al texto de Montesquieu. Es imprescindible para el programa propagandístico de Castro mencionar este clásico para aludir sobre la división moderna de las esferas de poder. Por consiguiente, éste indica que en El espíritu de las leyes (1748) se distinguen tres distintas clases de gobierno. El propósito es acusar las acciones del régimen de Batista. El autor nombra éstos: "Republicano, en que el pueblo entero o una parte del pueblo tiene el poder soberano; el Monárquico, en que uno solo gobierna pero con arreglo a Leyes fijas y determinadas; y el Despótico, en que uno solo, sin Ley y sin regla, lo hace todo sin más que su voluntad y su capricho” (Castro 247). Añade también una serie de descripciones negativas que nuevamente apuntan a la figura del dictador como "Un hombre al que sus cinco sentidos le dicen sin cesar que lo es todo, y que los demás no son nada, es naturalmente ignorante, perezoso, voluptuoso” (Castro 247). ${ }^{98}$

g. Cierre: regreso a la condición actual del inicio del texto

Al replantear los hechos sobre la condición en cautiverio y hacer una declaración de su culpabilidad, Castro retoma la imagen que muestra al comienzo de su ensayo. Así, presenta la impunidad de lo ya expuesto. Su vuelta al inicio apela de forma directa a la dinámica del concepto de lo histórico. Por esto, la historia ocupa el cierre del escrito como símbolo justiciero que sirve de figura de poder por encima del autor y los receptores del texto. 
Incluso, la historia es representada como ente omnipresente a lo largo de todo el discurso. Además, la conceptualización de la historia en el ensayo utiliza el factor del tiempo como herramienta determinante. Su noción simbólica sirve tanto para evocar los sucesos como para continuar la retórica de persuasión frente a la audiencia o al lector. ${ }^{99}$

\section{El concepto de la historia y la construcción de la metáfora}

Para presentar la historia como metáfora de la cultura caribeña en "La historia me absolverá”, conviene señalar distintos factores que contiene esta noción. De acuerdo a Maldonado, la historia es de interés teórico dada su función de “densidad temporal; [y de] la complejidad [que suscita] como el resultado mismo del tiempo” (17-18). Es un concepto que representa la temporalidad puesto que se alude a la narración de un pasado, expandiéndose a través de los ojos del presente: “...somos afectados y fecundados por las creaciones pretéritas, ampliándose nuestro propio horizonte temporal. ...consolidamos las intrínsecas semejanzas [con el pasado] y [así] la íntima vinculación de los tiempos” (González 25). Lo histórico opera entonces como recurso simbólico en el texto debido a que funciona como la representación de la síntesis del tiempo, en un todo simultáneo (pasado, presente y futuro). De ahí que el escrito que alude a hechos históricos, pueda tomarse la libertad de utilizar una estructura cíclica.

Así, la relación entre el presente y el pasado es evidente en toda narrativa histórica. Cuando se alude a la historia en un discurso, ésta funciona para retener una estructura abierta y simbólica, puesto que sirve para representar la conjunción de tiempos antes aludida. Por esto,

Lo contemporáneo hunde sus raíces en el pasado, pues fue en él donde se engendraron buena parte de los procesos de carácter objetivo o espiritual que la sociedad actual experimenta. Así, la cultura de un pueblo y los desarrollos o deformaciones económicas que una nación enfrenta son en su mayor parte fruto de un tiempo histórico muy anterior al momento presente. Las 
estructuras económicas, las mentalidades y las manifestaciones ideológicas, políticas y culturales de una sociedad concreta son hijas de diferentes tiempos históricos que se mueven desde la coyuntura e historia inmediata hasta la larga duración. (Santana-Castillo 220)

Los distintos eventos y procesos del ser humano mantienen un ritmo a lo largo del tiempo que depende de la constante fusión entre el pasado y el presente. Sin embargo, la forma en la que se interpretan los sucesos se moldea constantemente. Entonces, se suscitan las diferentes perspectivas históricas, ya que "la historia no es meramente lo fugaz y lo caduco. La obra moral [o, más bien, humana] -al igual que toda obra cultural- no está circunscrita a un solo momento histórico. Ella no se da sin antecedentes, y trasciende, a su vez, su propio tiempo” (González 29). Por consiguiente, los estudios históricos están sujetos a innumerables inquietudes, perspectivas e intereses, sobre todo cuando no hay suficiente distancia temporal con los fenómenos narrados (Maldonado 20). Así, en el ensayo de Castro, aunque se ofrecen diferentes distancias temporales, se presenta la interpretación de los hechos a partir de un sujeto (Castro) que no está distanciado temporalmente porque forma parte de lo que cuenta. Por lo tanto, la distancia con el tiempo que se rememora deja de ser real para convertirse en figurada.

En efecto, la historia es un eje que funciona como representación simbólica. Por esto, como narración o (re)presentación de la realidad siempre es cuestionable ya que depende de los propósitos de cada narrador o historiador. ${ }^{100} \mathrm{Al}$ ver la historia como un proceso que muestra las dinámicas del ser humano, funciona además como herramienta metafórica para la compresión de los hechos que suceden en la sociedad. Esto es porque la historia ulteriormente también se entiende “como reflexión -epistemología, filosofía, teoría-" (Maldonado 36). 
En la metáfora extraída en "La historia me absolverá” existe un andamiaje lingüístico y simbólico que enlaza con ideas que están presentes en todas las sociedades y culturas. De acuerdo a Erich Fromm, en El lenguaje olvidado (1951), lo simbólico, así como la simbología de los mitos y de los cuentos de hadas, reflejan el saber universal del ser humano. Al comprender dicho lenguaje hay una aproximación “...con las capas más profundas de nuestra propia personalidad", lo que provee "un grado de experiencias que es específicamente humano porque es común a toda la humanidad, tanto en su tono como en su contenido” (28). Para Fromm, el uso de lo simbólico muestra el mundo exterior como formador del interior, "representa nuestra alma y nuestra mente” (34). ${ }^{101}$ De este modo, el ensayo de Castro se apropia de símbolos, tales como las figuras del héroe, la de la justicia y la ética, para (con)figurar ambos mundos: el interno a través del externo. Recíprocamente, estos atributos representan figuras individuales que sirve para identificar al pueblo (lo externo) con el escritor (mundo interior).

Ahora bien, en el texto de Castro, se hilvanan eventos del pasado, vinculándolos con el presente y comprometiendo el futuro, funcionando así la historia como metáfora. Además, el tropo de lo histórico depende del punto de vista discursivo: de la expresión de sucesos reales, no obstante, supeditados a la ideología subjetiva del narrador. Habría que recordar que éste también es participe de los hechos, por lo tanto, ese lugar le permite una doble mirada (adentro y afuera). En particular, ilustra una continuidad de la individualidad humana adherida a hechos sociales a lo largo del tiempo. Así, en el escrito hay una correlación entre Castro (a partir de su encierro y exposición de defensa) y los símbolos que su figura y la historia representan. 


\section{Elementos y figuras simbólicas}

\section{El héroe}

A lo largo de todo el ensayo, Castro presenta y describe su propia imagen conforme a la figura mítica del héroe. El autor se autodefine a través de epítetos de carácter moral que apelan a lo heroico en el ser humano. Se recurre constantemente a vocablos tales como el honor, por ejemplo, cuando se indica que el honor de otros tiene gran importancia: “...de esos buenos profesionales, dejo limpio de toda duda su honor, que vale mucho más” (Castro 5); también, las referencias a la valentía ("Los revolucionarios han de proclamar sus ideas valientemente” (25)), la verdad y la justicia (“un gobierno aclamado por la masa de combatientes, recibiría todas las atribuciones necesarias para proceder a la implantación efectiva de la voluntad popular y de la verdadera justicia” (26), entre otras más. Estas alusiones sirven como modo de persuasión y le permiten al ensayista presentarse ante la sociedad como un ente capaz de dirigir efectivamente al pueblo. Asimismo, con el uso de términos que apelan a lo heroico, el escritor se hace portador de los ideales que funcionan en la cultura latinoamericana para la formación de una identidad nacional. ${ }^{102}$

Según Pierre Grimal, en su Diccionario de mitología griega y romana, el mito heroico se define estrictamente de acuerdo “a una narración que se refiere a un orden del mundo anterior al orden actual, y destinada no a explicar una particularidad local y limitada ..., sino una ley orgánica de la naturaleza de las cosas” (xv). En este sentido, el mito se relaciona con la historia, con la dependencia de una narración pasada. No obstante, tanto en el mito como en la historia se insertan figuras reconocidas por acciones heroicas. En el escrito de Castro, se subrayan algunas como Abel Santamaría y los demás compañeros caídos, incluyéndose de modo indirecto a él (como uno de los participantes del Moncada). Con esto, el ensayo 
manifiesta una apropiación de elementos del ciclo mítico que dan unidad al texto, por una parte, a través de esas figuras heroicas incluidas.

Igualmente, al narrar los eventos se busca constatar una gesta revolucionaria cubana que había sido iniciada por los llamados héroes del pasado. De forma similar a las afirmaciones de Grimal, en el ensayo castrista también las proezas de estos ídolos surgen a partir de un amalgamiento de elementos de distintos tiempos (Grimal xvii). Por lo tanto, los mecanismos que crean la imagen del héroe están relacionados con el factor temporal, es decir, con la historia, fundamentalmente porque los 'ciclos heroicos' "no nacen de una vez, sino que se van formando en el curso de una larga evolución” (xviii). Esto quiere decir que lo heroico, con el paso del tiempo y con su valor simbólico comienza a plasmarse en el mito, o lo que es lo mismo, en la historia.

Por consiguiente, la noción de la historia como expresión sintetizadora del tiempo juega un papel preponderante en la formación de la figura del héroe. Primeramente, Castro no puede identificarse a sí mismo como héroe sin proyectarse en un contexto histórico. Por supuesto, éste necesita de la 'autoridad' que la historia representa. Sin embargo, el autor utiliza la historia como figura metafórica. Esto es, ya que “...el mito, al correr de los tiempos, [accede] a una contemplación mística de la realidad que expresa. La narración no es más que un punto de apoyo accesorio y, como tal, un revestimiento carnal” (Grimal xvi). Es decir, los relatos en el texto sirven para adornar y rellenar la intención del ensayista; acompañan el conjunto de imágenes simbólicas (y no viceversa). Por esto, en "La historia me absolverá” las adiciones narrativas sirven para ilustrar esa metáfora histórica. Por una parte, lo heroico, en tanto símbolo, aporta en la configuración general del escrito; por otro lado, valida la realidad social a través del tiempo, haciendo que el presente se inscriba en la 
historia: “...casi todas las acciones atribuidas al héroe son simbólicas,... como una expresión de una función social, residuo de viejos ritos ‘políticos’...” (Grimal xix).

Castro, en este ensayo comienza a construir los símbolos que marcarán la revolución cubana como momento mítico de la historia de la isla. Por esto, se denota una identidad colectiva. De un lado, la confrontación del Moncada se menciona, no precisamente para narrar un hecho histórico sino para apelar, ampliar e insertar el colectivo heroico cubano en una realidad social actual. Así, el discurso mantiene la intención de querer salvaguardar las masas ya que el pueblo, al identificarse con el autor y los combatientes del Moncada, es también portador de esos epítetos heroicos. Inclusive, se trata de una línea de héroes que marcan la historia cubana, considerando primordial la figura de José Martí, el “apóstol”, como precursor de la lucha revolucionaria a favor de la independencia de la isla. ${ }^{103}$ Consecuentemente, para cerrar esa enumeración de héroes, Castro añade a los “mártires” del Moncada (incluyéndose a sí mismo).

El suceso del Moncada entonces le otorga a Castro los primeros pasos para su formación como héroe. ${ }^{104}$ Sin embargo, su encierro y, luego, el aislamiento en la cárcel también funcionan como una especie de tránsito para la autoconfiguración de su imagen heroica. ${ }^{105}$ Así, con la entrada a la prisión se comienza a configurar la idea del héroe en la que el escritor esboza, conscientemente, sus particularidades. A través de la exposición ante el Tribunal de Urgencias y, luego, la puesta en papel para distribuirla, el reo se ilustra tanto como una figura redentora para su pueblo como también como ente aterrador para sus enemigos. Así, el joven Castro se reconoce en su posición de héroe de la revolución. Esta consciencia es notable, por ejemplo, cuando el autor habla de la muerte como la opción preferente antes de ver fracasado su designio, puesto que su caída, como la de cualquier figura heroica, "también conduce a una nueva vida. ...el drama de un nuevo nacimiento por medio de la muerte” (Jung 122). 
Ahora bien, Rafael López-Pedraza indica, en Sobre héroes y poetas (2002), que las características del héroe son particularmente importantes dentro del imaginario ideológico adoptado en toda Latinoamérica. Esto no es un elemento exclusivo de los dirigentes de las masas sino que está inserto tanto en el carácter del sujeto como también en el de la cultura de los países hispanos. Para López-Pedraza se trata de un sentimiento que implica incluso sufrimiento y que, por lo tanto, afecta la psicología del individuo: "Puede que lo que nos hace participes de esta emoción se dé cuando el sufrir de un hombre, un ser humano individual, tiene como telón de fondo un sufrir colectivo e inconsciente” (9). Por consiguiente, la figura y el mito del héroe, aun relacionados de forma particular con un individuo, trata simultáneamente un sentir plural que sucede a nivel inconsciente en un grupo social. ${ }^{106}$ Así, la identidad hispanoamericana está circunscrita tanto como expresión individual como colectiva.

Considerando lo dicho, en este discurso se entrevé la metáfora de la historia como representación cultural, en particular, cuando el escritor alude a una común identidad nacional a través del reconocimiento de figuras históricas y heroicas de la historia cubana:

Pero hay una razón que nos asiste más poderosa que todas las demás: somos cubanos, y ser cubano implica un deber, no cumplirlo es un crimen y es traición. Vivimos orgullosos de la historia de nuestra patria; la aprendimos en la escuela y hemos crecido oyendo hablar de libertad, de justicia y de derechos. Se nos enseñó a venerar desde temprano el ejemplo glorioso de nuestros héroes y de nuestros mártires. Céspedes, Agramonte, Maceo, Gómez y Martí fueron los primeros nombres que se grabaron en nuestro cerebro; ... Nacimos en un país libre que nos legaron nuestros padres, y primero se hundirá la Isla en el mar antes que consintamos en ser esclavos de nadie. (Castro 251-2; mi énfasis)

Se identifica así lo cubano al establecer un orgullo colectivo que se obtiene a través de la instrucción de la historia del país. La cualidad común que valida la relación entre el héroe y la masa es precisamente el ser cubano. Esto entonces asegura que Castro y sus colaboradores 
queden insertos en ese desfile de personajes históricos de la isla; se menciona además el deber que tiene el pueblo frente a la historia y a estos héroes cubanos:

No es con sangre como pueden pagarse las vidas de los jóvenes que mueren por el bien de un pueblo; la felicidad de ese pueblo es el único precio digno que puede pagarse por ellas. ... Mis compañeros, además, no están ni olvidados ni muertos; viven hoy más que nunca y sus matadores han de ver aterrorizados cómo surge de sus cadáveres heroicos el espectro victorioso de su ideas. (Castro 235; mi énfasis)

De esta manera, continúa la configuración de un ideario heroico. Esa representación además funciona de acuerdo al propósito de persuadir a la audiencia. Así, el texto ilustra un devenir del héroe colectivo que proviene inicialmente de la configuración de héroes individuales, como Castro y los combatientes del Moncada.

La justicia

La justicia es un concepto moral que ha sido objeto de estudio desde la antigüedad por muchas civilizaciones. Se trata de una noción mutable, por lo tanto su carácter o definición cambia de acuerdo a las evoluciones de las diferentes generaciones (Ball 148). Aun así, la tradición estipula un consenso de ideas generales que establecen lo que es justo para una civilización y otra, o para distintas progenies. De esta forma, para un dirigente proclamarse exitosamente en la esfera del poder político debe pronunciarse a favor de la justicia y de los derechos del pueblo.

En su rol como figura de poder, Castro, de acuerdo al lugar que ocupa como héroe, ejerce el papel de protector de la justicia:

Todo el mundo tenía instrucciones muy precisas de ser, ante todo, humanos en la lucha. Nunca un grupo de hombres armados fue más generoso con el 
adversario[;] ... tuvo la justicia de reconocer como un hecho indudable el altísimo espíritu de caballerosidad que mantuvimos en la lucha[;] ... el valor humano fue igualmente alto de parte y parte. (Castro 201)

A través de esta retórica, ideológica y política, el líder apela a un sentido de equidad entre los grupos enfrentados en el Moncada. Por un lado, la caballerosidad y generosidad de los combatientes que dirige Castro alude al carácter heroico de éstos. De otra parte, la noción de justicia sirve como elemento que muestra esa representación heroica y funciona como símbolo que ayuda a construir la metáfora de la identidad cubana. Además, apoya en la elaboración de las ideas de persuasión política y crea un andamiaje figurado que conecta conceptualmente la propuesta castrista. Así, la imagen de la justicia es un eslabón que enlaza con la figura del héroe; ambas nociones están correlacionadas: una figura salvaguarda a la otra.

Para mantener el maderamen alegórico del ensayo, el autor continúa valiéndose de la autoridad del pasado. Por esto, al hacerse referencia en el texto sobre la justicia también se crea una conexión con la antigüedad: entreteje alusiones a mitos y simbologías ancestrales. Por consiguiente, ésta es una figura básica que representa uno de los fundamentos humanos de la tradición occidental, específicamente alude al mito de la edad de oro que "se convirtió en un tópico de la moral, que se complacía en pintar los principios del género humano como el reino de la Justicia y la Buena Fe” (Grimal 146). De hecho, la noción de la justicia en el discurso castrista denota el tópico de la moral y la ideología que quiere presentar el ensayista.

De igual modo, las referencias sobre la justicia, en tanto concepto humano, bien pueden ser modificadas según la perspectiva que se tome. Terence Ball indica que existe una separación entre las 'concepciones’ de la justicia y ‘el concepto’ de justicia. En Transforming Political Discourse. Political Theory and Critical Conceptual History, se 
advierte que: "Conceptions of justice come and go, but the concept of justice endures. Thus there is a transhistorical core of the concept of justice that is somehow immune to the ravages of history and to which these various conceptions are somehow connected” (Ball 148). Por esta permanencia transhistórica del concepto de la justicia, es que Castro interconecta el valor del término con la tradición. En una entrevista con María Asunción Mateo en 1991, éste revela que en su ensayo existe la presunción de la relatividad de la justicia y, también, su correspondencia con el tiempo y la mirada de las distintas generaciones:

Tiene un sentido relativo, en el que el pueblo reconocerá un día la justicia de nuestra causa. Los hechos nos darán la razón, fue lo que quise decir, y así fue. Cada día hay otra nueva historia, toda la historia de la Revolución, del proceso revolucionario, de la construcción del socialismo en Cuba, con nuestros aciertos y nuestros errores. ...más tarde o más temprano los pueblos nos darán la razón. ... cuando tú tienes confianza absoluta en la justeza de lo que estás haciendo, es en ese sentido en que yo diría otra vez: la historia me absolverá. (Castro en Guerra-López 286; mi énfasis)

Aquí, se reconoce la mutabilidad del término y de la historia. Pues, "Virtually all of our concepts are historically mutable ones whose meanings change over time. 'Justice' is no less mutable than other concepts in our moral and political vocabulary” (Ball 149). Ball, citando a Kiekergaard acerca de la inflexión y maleabilidad de los conceptos, igualmente indica que éstos tienden a ser como los individuos, ambos "have their histories, and are just as incapable of withstanding the ravages of time...” (149). De este modo, la justicia y la historia son nociones que están incuestionablemente vinculadas al factor del tiempo.

De hecho, existe una relación simbólica recíproca entre ambas figuras. Es decir, la historia queda inserta en la conceptualización de la justicia y, viceversa, la representación de la justicia está entretejida en la estructura del ensayo a través de la metáfora de la historia. Ambas figuras permanecen con el pasar del tiempo: "But what is true of the past is no less true of the present. The present is forever slipping into the past. If history teaches us 
anything, it is that the concepts constitutive of our moral frameworks, political theories and social practices are no exception to the rule that nothing human last forever” (Ball 149). ${ }^{107}$

La justicia, además de relacionarse con la realidad del presente supeditada al pasado, se adecúa a las respectivas sociedades. Michael Walzer en Spheres of Justice indica que la justicia “is relative to social meanings", que una sociedad en particular "is just if its substantive life is lived in a certain way -that is, in a way faithful to the shared understanding of its members” (Walzer 313). Por eso, el que se imparta o entienda la justicia dentro de un conjunto social depende de los valores que comparten los miembros de ese mismo grupo. Las creencias y entendimientos fuera de dicha comunidad no alteran las concepciones aceptadas dentro de cada conjunto particular. Por lo tanto, en el contexto cubano prerevolucionario existe un sentido de la justicia que se crea y entiende en el interior de esa sociedad y de ese momento histórico. Constantemente, el factor del tiempo y las distintas concepciones de cada uno de los miembros de las diferentes sociedades y sus culturas determinarán el valor del concepto de la justicia. Así, la idea de la justicia es semejante a la conceptualización de la historia. Ambas nociones son maleables y cambian de acuerdo a las intenciones de los entes de poder: "Far from being fixed and frozen, the 'boundaries' between 'sphreres' are regularly violated and periodically redrawn. History is in large part the story of such 'shifts in social meaning'” (Ball 157; Walzer 319). Es decir, los conceptos de la justicia y la historia están en constante delineamiento y conjuntamente se desplazan según las formas de pensar de los miembros de cada sociedad.

Por otro lado, Castro establece en el texto que la justicia es un ente femenino, débil y vulnerable. El concepto está configurado como víctima de violación: “La doncella de la justicia, dos veces violada por la fuerza” (Castro 239); e incluso ésta hasta corre el riesgo de ser prostituida: 
Los pueblos poseen una lógica sencilla pero implacable, reñida con todo lo absurdo y contradictorio, y si alguno, además, aborrece con toda su alma el privilegio y la desigualdad, ése es el pueblo cubano. Sabe que la justicia se representa con una doncella, una balanza y una espada. Si la ve postrarse cobarde ante unos y blandir furiosamente el arma sobre otros, se la imaginará entonces como una mujer prostituida esgrimiendo un puñal. Mi lógica, es la lógica sencilla del pueblo. (Castro 236-7; mi énfasis)

De este modo, la deshonra de la justicia sucede como resultado de un gobierno que la imparte desigualmente. También, esta figura es la encarnación del cuerpo político y durante la dictadura batistiana se muestra desprovista de salud y de libertad, puesto “...que se imparta la justicia desde el cuarto de un hospital... pudiera [hacer] pensar [a] la ciudadanía que nuestra justicia está enferma... y está presa” (Castro 196). Al utilizarse tales adjetivos, se establece una relación entre el prisionero, Castro, y la Justicia: ambos en cautiverio, en un hospital para ser cuestionados. ${ }^{108}$ Así, la figura del reo desempeña un papel múltiple: es héroe y al mismo tiempo Justicia, es abogado defensor y también fiscal, es un acusado culpable e igual inocente. ${ }^{109}$ Por esto, en la figura de Castro están representados los elementos que forman el entramado metafórico.

Ahora bien, en la tradición cultural latinoamericana la imagen de la justicia como ser femenino surge de manera paralela a la del héroe como ente masculino. Primero, recordemos que, como indica Ángel Romera, “una balanza es alegoría de justicia: ... el símbolo se caracteriza por su permanencia fija en el seno de una cultura... Así puede verse que el símbolo es colectivizado poco a poco por una cultura y que, inversamente, puede ser descolectivizado y personalizado con un significado diferente”. ${ }^{110}$ En el ensayo, Castro nombra a la justicia como doncella (sinónimo de virgen), sabiendo que es un símbolo colectivo y, por lo tanto, se reconoce culturalmente; ésta debe ser salvaguardada por el héroe. El autor se vale de figuras como la, “[del] héroe y la virgen [porque] son elementos predominantes en nuestros mitos, cultos y psicología. ... [P]uede decirse que este es un nivel 
básico de nuestra identidad” latinoamericana (López-Pedraza 23). Asimismo, dado a que se establece en el texto que la Justicia es violada por Batista (que para el mito europeo es secuestrada), ésta necesita de un héroe como Castro para defenderse. Precisamente, Castro dice en su discurso que tiene la "capacidad para salvar o proteger de [los] peligros terribles” (Castro 123) a esta doncella llamada Justicia.

\section{La ética}

Del mismo modo que la justicia se menciona constantemente en el ensayo, también así la noción de ética. El texto se construye proponiendo una moral humana, es decir, una ética, que tiene como fin un bien social. Por lo tanto, la ética va a delimitar el carácter del héroe, ya que éste actúa a favor de una conciencia moral-social. Del mismo modo que los símbolos antes mencionados, la ética se relaciona también con el carácter de la historia. Estos trascienden la conceptualización del tiempo aun estando adscritos irremediablemente a éste, pues, “La ética del presente no puede gestarse sin pasado y sin memoria” (González 24).

De acuerdo a Juliana González en Ética y libertad, aunque la realidad de los hechos que presenta la Historia es incambiable, la manera en que el ser humano la interpreta va a depender de los valores adjudicados en los diferentes eventos del pasado. Sin embargo, la apreciación moral que se tengan del pasado igualmente es maleable, pues, depende de la perspectiva ideológica que se adopte, cada vez que se reconsidere:

El pasado puede ser iluminado - u obscurecido- por el presente, tanto como el presente lo es por el pasado (énfasis de la autora). Pues aunque éste sea en sí inalterable y pese sobre nosotros como un cuerpo denso, fatal e inamovible que nos limita y determina, y aunque obviamente no podamos regresar y cambiar la realidad pasada, ésta no es unívoca; recaemos no obstante sobre ella alterando si no su ser, sí su significado; asumimos de diferentes maneras lo ocurrido y transformamos así su valor y su repercusión efectiva. (González 24; mi énfasis) 
De acuerdo a lo señalado, la narración en "La historia me absolverá” sirve para inscribir los hechos en el tiempo, colocándolos ante el juicio de la historia. Así, el texto asume un carácter ético para evaluar y explicar esos sucesos. Por esta razón, los eventos que surgen alrededor del ataque al Moncada toman forma de acuerdo a una serie “...de valores que tenían como centro un imperativo moral para justificar la acción política” (López-Ávalos 96). Esa inquietud moral le permite establecerse al autor como figura heroica y, como tal, exigir su libertad para, luego, tener la posibilidad de ofrecer la misma a la masa.

\section{Historia como cultura}

La narración histórica busca mostrar como verdadero el enfoque que el historiador trasmite. Lo que se expresa, dado a su carácter subjetivo, puede ser una invención (como lo es lo heroico). De acuerdo a Hayden White, esto permite describir la historia y sus mecanismos como metáforas, puesto que construyen en su narrativa, a través de patrones de significados, formas similares a las de la ficción poética:

...there is a mythic element in proper history by which the structures and processes depicted in its narratives are endowed with meanings of a specifically fictive kind. A historical interpretation, like a poetic fiction, can be said to appeal to its readers as a plausible representation of the world by virtue of its implicit appeal to those 'pregeneric plot-structures' or archetypal story-forms that define the modalities of a given culture's literary endowment. (White 58)

Por consiguiente, la historia expresa particularidades de las múltiples culturas a través de modelos simbólicos, según el dictamen de cada historiador. Igualmente, la historia caribeña sirve como prototipo figurado que representa su cultura.

Los símbolos utilizados en el ensayo de Castro (la figura del héroe, la de la justicia, la 
ética, la historia misma, etc.), son arquetipos plausibles del mundo que describe. ${ }^{111}$ Así, éstos forman un entramado metafórico que, "Ya no es una compilación de creencias, sino un instrumento de expresión, una retórica o una poética de por sí, y es muy significativo[, ya que] ... el pensamiento y la expresión míticas no son sino una de las vías abiertas a la literatura” (Grimal xxv). De ahí que las formas de expresiones simbólicas, tanto en la literatura como en la historia y en la política, están abiertos a la interpretación de quien lee. Así, los distintos modelos funcionan de acuerdo a la(s) perspectiva(s) que toman la interpretación histórica y el lector. ${ }^{112}$

La historia envuelve una serie de sucesos, sean "políticos, sociales, económicos, culturales, etc., de un pueblo o de una nación” (DRAE historia). Así, uno de los tantos enfoques que puede tomar es la exposición del conjunto cultural de una sociedad. En este sentido la historia se reúne y (re)crea en esferas temporales de larga duración (Wallerstein), “nuevo[s] espacio[s] de conocimiento y, en consecuencia, un nuevo espacio social” (Maldonado 46). Entonces, referirse a la historia le permite a Castro fraguar en su discurso la propuesta de nuevas leyes que luego instituye al ocupar el poder. ${ }^{113}$ Así, el autor hace que la palabra aquí escrita sea ley avant la lettre y, al mismo tiempo, la convierte en la realidad del espacio social futuro. De este modo, en el ensayo, la ambigüedad de la historia, su autoridad y, al mismo tiempo, su maleabilidad, son recursos que recargan su metáfora de significado, en ese nuevo espacio social.

\section{Castro, la historia y Calibán}

El escritor barbadense George Lamming, en los ensayos “A Monster, A child, A Slave” y “Caliban Orders History”, publicados en el libro The Pleasures of Exile (1960), presenta cómo la figura de Calibán funciona como símbolo del Caribe revolucionario. Específicamente, en el primero de estos ensayos, se advierten las posibilidades metafóricas 
que tiene el personaje de Calibán de la obra teatral La tempestad de Shakespeare. En el segundo escrito, Lamming propone cómo en la revolución haitiana, narrada en The Black Jacobins (1938) de CLR James, Toussaint Louverture es semejante a Calibán, es decir, sirve como figura que representa al esclavo (la masa) que se revela en contra del colonizador Próspero (el abuso del poder).

La figura de Calibán ha sido sumamente estudiada, sobre todo, en relación al contexto colonial. En Latinoamérica, Roberto Fernández Retamar publica una serie de ensayos en los que, en lugar de enfocarse en la figura de Ariel, como lo hizo José Enrique Rodó, se concentra en la de Calibán. En Todo Calibán, una de las últimas publicaciones de las reediciones de estos ensayos, Retamar reconoce que George Lamming es el primero en señalar coherentemente un análisis sobre la metáfora de Calibán como signo positivo del colonizado que lucha por su libertad (esta metáfora de Calibán había sido utilizada antes pero para representar un aspecto negativo de la figura).

Recordemos que Calibán representa al esclavo que se rebela utilizando las mismas herramientas (el lenguaje) que el amo le provee para servirle. Por eso, Lamming indica que, "Caliban contains the seed of revolt” (98). Esto es que éste, al ser esclavizado y luego encarcelado, contiene el germen de lucha por la libertad. La imagen de los esclavos, en general, o de Calibán, en particular, sirve como símbolo de la sociedad colonizada: "they worked, and were rebellious and often went wild with the spirit of freedom, and were imprisoned, and yet, like Caliban, they survived as though there were some divinity which made them unique in their capacity to last” (Lamming 98). Por lo tanto, Calibán como metáfora es el esclavo y, por ende, representa la masa colonizada de América, específicamente, del Caribe.

De la misma manera en la que Lamming reconoce a Louverture como poseedor de las 
cualidades metafóricas de Calibán, así puede indicarse que la figura de Fidel Castro también adquiere esos atributos. En específico, al igual que "Caliban is a victim... But the spirit of freedom never deserts him (Lamming 101), también Castro aparece como víctima, sin dejar de abogar por la libertad del pueblo. Por otra parte, ni Castro ni Calibán pierden el sentido del pasado. En el escrito de Castro está presente el factor histórico, por supuesto el pasado, como un reflejo de agarrarse de la raíz, de la tradición (como lo es la alusión a José Martí, entre otros). Para Lamming, igualmente, "Caliban has not lost his sense of original rootedness" (101).

Ahora bien, la metáfora de Calibán funciona para representar a toda la cultura latinoamericana y caribeña, incluso, desde la llegada de los colonizadores a estas tierras. Retamar lo advierte indicado que,

...el poderoso concepto-metáfora que es Calibán (insisto: un 'conceptometáfora', en forma alguna solamente 'un nombre en una pieza’) aludirá en estas páginas no sólo a la América Latina y el Caribe sino, como ha sido tan frecuente, a los condenados de la Tierra en su conjunto, cuya existencia alcanzó dimensión única a partir de 1492. (“Calibán quinientos...”, Retamar 2)

Por eso se encuentran semejanzas entre algunas figuras o personajes históricos con Calibán, entre los que están Toussaint Louverture (Lamming), José Martí (Retamar) y Fidel Castro. Con la aparición del personaje de Calibán en la literatura, su metáfora comienza a expandirse, al punto que su historia comienza a ser la historia del futuro de América y el Caribe. Ya bien Lamming y Retamar lo recalcan, la turbulenta historia de Calibán pertenece al futuro (Lamming 107; Retamar 23). 
Por consiguiente, la referencia al futuro lleva inmediatamente a enlazar el concepto de la historia según lo maneja Castro. En el ensayo castrista, es en el futuro que la absolución se llevaría a cabo. Por otro lado, es la historia de Calibán la que también es parte del futuro. Ambos, son parte de la historia caribeña, sus figuras están adheridas a esa historia, al futuro y, por lo tanto, a la incertidumbre. También, el futuro son las posibilidades. De ahí se reconoce otra de las maneras de leer la metáfora-Calibán: “Caliban is in his way a kind of Universal... He confronts Prospero as a possibility; a challenge; and a defeat (Lamming 108). Igualmente, tal como el autor barbadense lo afirma, por eso Toussaint Louverture emerge como un símbolo universal, y en particular de la historia del Caribe (Lamming 136). Siguiendo esta línea de pensamiento, la figura de Calibán implica entonces una historia de personajes y consecuencias, de intenciones futuras desconocidas (109).

Las alusiones a lo heroico, y a las demás metáforas, en el ensayo de Castro tienen un valor etiológico. Es decir, tienen como propósito explicar las causas de las cosas, específicamente, de eventos que forman parte de la historia. La figura heroica a lo largo del texto enlaza referencias metafóricas a través de las anécdotas y ejemplifica particularidades de una imagen cultural cubano-caribeña. Sin embargo, no hay un sujeto que, solo, se acentúe como único héroe, sino que, como portadores de estos componentes heroicos, se suman a la historia el grupo de próceres cubanos y, por ende, la masa. Sucede igual con la figura de Calibán, que como se ha indicado, éste representa la sociedad colonizada desde un punto de vista heroico y positivo. Por lo tanto, partiendo de lo individual, en las figuras de Castro y Calibán se representa, luego, lo plural que, particularmente en el Caribe, es parte de lo cultural.

En "La historia me absolverá” se construye un marco teórico y práctico que intenta fortalecer y reformular los pasos futuros del movimiento revolucionario. Este plan estratégico no es solamente en cuanto a lo político sino también en favor de validar una 
identidad nacional común. Así, las ideas de la propuesta se superponen a las esferas de poder. Es decir, por encima de los niveles de represión, representados en la figura de Batista y en su régimen dictatorial, Castro establece una concientización moral que repercute en el plano de la cultura. De esta forma, las distintas metáforas que utiliza el ensayo sirven para consolidar simbólicamente el perfil cultural de los cubanos.

De esta manera, la metáfora de la historia da continuidad a algunas de las propuestas de identidad cultural en el Caribe de la primera mitad del siglo XX. Por un lado, Castro expresa ideologías similares a las que Césaire expone, ya que ambos muestran un humanismo en donde se habla de la libertad del hombre y de la 'locura’ de poseer dicha liberación. Con esta interconexión ideológica, el tropo de la historia en Castro se muestra como parte de esa “Organicidad, continuidad, coherencia; también [vislumbra] cambio. ...[como] la construcción de una lectura política de la historia, más directamente comprometida con los debates del presente inmediato"::114

...pudiera pensarse que yo me circunscriba a los mismos y dé vueltas y más vueltas alrededor de ellas, como un esclavo en torno a una piedra de molino. [...] ...se discute sobre cuestiones fundamentales de principios, se juzga sobre el derecho de los hombres a ser libres, se debate sobre las bases mismas de nuestra existencia como nación civilizada y democrática. Cuando concluya, no quiero tener que reprocharme a mí mismo haber dejado principio por defender, verdad sin decir, ni crimen sin denunciar. (Castro 198; mi énfasis) ${ }^{115}$

Más allá de lo dicho, estas propuestas metafóricas buscan recalcar un alejamiento de las fuentes de poder. A través de estas construcciones simbólicas no solo se ilustran nuevas visiones de los grupos que enfrentan el poder dominante, sino que igualmente proyectan una objeción del orden establecido (se ve en las figuras de Castro y de Calibán). Aquí, la historia contiene la representación de la figura heroica, las conceptualizaciones de libertad (ética y justicia), absolución e impunidad. Por consiguiente, consciente de este entramado histórico- 
metafórico, Castro entonces afirma que no teme a la cárcel, ya que, como héroe, osa entregarle el poder, no solo de su propia libertad sino también del cierre de su discurso, a la historia misma: “Condenadme, no importa, La historia me absolverá” (Castro 253). El líder cubano, desde la escritura de su ensayo (re)conoce el papel que juega: "el hombre como individuo dirigente de las masas que hacen la historia” (Guevara 5). 


\section{Capítulo 4:}

\section{Las metáforas de la criollización/creolization y la síntesis espiritual-cultural: integración}

\section{y desintegración}

“El mestizaje es concepción constante”

\section{Criollización/creolization: integración}

Enrique Laguerre.

Durante varios años en la década del setenta, el escritor y académico Edward Kamau Brathwaite publica minuciosos análisis sobre el concepto de la criollización o creolization. En The Development of Creole Society in Jamaica 1770-1820 (1970), el autor elabora un estudio histórico, económico y político de la sociedad jamaiquina, concluyendo con un acercamiento detallado acerca del vocablo en los dos últimos capítulos. Además, este trabajo se extiende en White Power in Jamaica: the inter-dynamics of slave control (1971). Ambos textos son resultado inmediato de su investigación doctoral terminada en 1968. En 1973 el ensayista desarrolla el concepto en su ponencia, "Contradictory Omens: Cultural Diversity and Integration in the Caribbean”, presentada en el congreso sobre Creolization in Africa and the Americas en la Universidad Johns Hopkins en Baltimore. El año siguiente Brathwaite escribe un breve panfleto en Publicaciones Savacou titulado, Caribbean Man in Space and Time (1974). Los escritos mencionados se consideran, según Jane Webster, los más influyentes sobre el tema: “The earliest and most influential study of creole cultural development” (217).

La criollización o creolization califica el devenir de la cultura caribeña y se define como un continuo proceso que trasciende tiempo y espacio, que se desarrolla a lo largo de un conjunto de etapas sucesivas, tanto del acontecer histórico como de las dinámicas que se dan a partir de los eventos que van surgiendo entre los habitantes de cada una de las islas y de sus respectivos entornos. De este modo, en el presente trabajo el concepto es visto como una 
construcción de elementos híbridos que funciona como metáfora cultural caribeña. Según Brathwaite, el término identifica una acción cultural o un proceso social basado en los estímulos y respuestas recíprocas entre los individuos de una sociedad y su medio:

The single most important factor in the development of Jamaican society [and of the Caribbean] was... a cultural action -material psychological and spiritual- based upon the stimulus/response of individuals within the society to their environment and- as white/black, culturally discrete groups - to each other. (The Development... Brathwaite 296)

Así, la criollización sucede sobre todo en la relación entre blancos y negros bajo el sistema colonial que establece una dinámica del dominante sobre el subordinado. Es decir, estas interacciones tienen un alcance que depende de las circunstancias que fundan y componen la sociedad caribeña en la que se cimenta una ‘nueva cultura’ a raíz de otras.

Todas las connotaciones del concepto, incluso antes de los estudios que hace Brathwaite, coinciden en que el engranaje de los factores que forman la criollización emerge durante el régimen colonial. También, aluden al encuentro de varias culturas y a las relaciones de poder que inevitablemente se desarrollan en dicho contexto:

El término “creolization” surge de los estudios realizados sobre las sociedades afro-americanas y afro-caribeñas que surgieron del contacto entre europeos, americanos nativos y africanos... Estas visiones insisten en los "procesos de negociación" en contextos marcados por relaciones de poder desiguales a partir de los cuales se construye una nueva cultura material fruto de una realidad social nueva, hecha de la amalgama de tradición e imposición, que no puede entenderse como la reproducción de la cultura del dominante. (Sastre 378)

De modo semejante a la criollización, Alejo Carpentier presentó el término de sincretismo cultural. La obra de este autor muestra cómo a partir de los binomios blancos y negros, colonizador y colonizado, surge un sincretismo, es decir, la existencia de “dos [o más] 
realidades [culturales que] coexisten” (Corticelli 123). ${ }^{116}$ El sincretismo carpentiano es contrario a insubordinarse puesto que está relacionado, más bien, con la pasividad y convivencia. En particular, el sincretismo es "producto de una simbiosis, de un mestizaje; ...una cultura esencialmente mestiza y criolla” (198). Esa mezcla es, de acuerdo al mismo Carpentier, un crisol de la confluencia de distintas culturas, de distintas procedencias. La criollización sin embargo está marcada por negociaciones de acuerdo a las relaciones de poder dadas en el contexto caribeño. La criollización busca expresar la integración cultural en la sociedad. En ambos casos, se trata de un proceso que resulta en una coexistencia en la que no hay una cultura que domina.

Al contrario, el sistema colonial establece una separación entre los individuos de distintos grupos o clases sociales-étnico-económicas. Sin embargo, Brathwaite propone esta metáfora caribeña a partir de la concomitancia de estos componentes y a pesar de las disgregaciones establecidas. De esta forma, en un mismo vocablo se alude a la mezcla racial y al contexto histórico que la propicia. Incluye además todos los elementos que denotan la hibridez cultural del Caribe, no solo en el plano de lo perceptible, evidenciado primordialmente en el color de la piel, sino también en los modos de vida y comportamiento; por ejemplo, en las convenciones del mercado, en estilos de baile y las especificidades de la música, en las caracteríscas genéticas-físicas, en las prácticas religiosas, entre otros ámbitos. Asimismo, dicho proceso social funciona en un nivel abstracto. Particularmente, en todo aquello que pretende representar la proporción, la forma o la cierta manera ${ }^{117}$ en la que se expresa esa criollización como espejo de las dinámicas culturales y sociales en un nivel macro o global. Se manifiesta así la versatilidad y el movimiento, en tanto proceso, de la cultura caribeña. 


\section{Formación de la 'criollización’}

Según lo expone George Beckford, citado por Brathwaite, la criollización comienza con la fase de seasoning. Esto es, un periodo de tres años en el que se catalogaban a los esclavos, se les daban nuevos nombres y pasaban por un tiempo de aprendizaje que los transformaba y los instruía en una nueva lengua y en nuevas rutinas laborales. Esta etapa de familiarización con la nueva vida prepara el terreno de las subsiguientes actividades sociales que luego tienen lugar en los tiempos libres de los esclavos. ${ }^{118}$ De tal modo, el seasoning funciona como proceso que dispone al esclavo para un consciente y determinado método de control.

La segunda etapa en esta configuración cultural es la socialización. ${ }^{119}$ Ésta sucede tan pronto comienzan a comunicarse unos esclavos con otros, formando grupos o bandas que llevan a cabo algunas actividades comunales o recreativas, tales como los bailes, los toques de tambores y los festivales (The Development... Brathwaite 298). A partir de la comunicación entre esclavos, sigue un sentido de restauración y afirmación dentro de cada grupo, denominado communalization (Contradictory... 13). Estos procedimientos son esencialmente importantes para los esclavos de las plantaciones, puesto que se diseñan para que el cautivo desarrolle un sentido de identificación con el trabajo impuesto. Con esto, se busca sublimar el descontento y el sentido de pérdida de los subordinados (13). Según Brathwaite, la identificación con los grupos, así como con los símbolos locales de autoridad, y la imitación de todo aquello con lo que los esclavos se sienten asemejados, son procesos cruciales para la configuración de la 'nueva’ cultura. Asimismo, influye también el contexto fuera de las islas. En el Caribe, específicamente en el caso de Jamaica, la guerra de independencia de los Estados Unidos (1775-83) crea lazos tipo tela de araña que operan bajo el imperio británico (The Development... Brathwaite 244-5). Es decir, estos eventos se interrelacionan formando disposiciones, conscientes e inconscientes, que revelan aun más 
dinámicas. Por consiguiente, estas distintas fases construyen y establecen la sociedad criolla o ‘créole’. Incluso, hoy día persiste este movimiento que se delimita por la relación cultural, política y económica con los grandes imperios. ${ }^{120}$

Entonces, según el ensayista la criollización se forma de una manera estructurada en la que se dan ciertos patrones. Estos son esquemas que, en mayor o menor grado, forman parte de la mezcla cultural en cada una de las islas caribeñas: las culturas del blanco y del esclavo se remedan simultáneamente durante el periodo de socialización. Sin embargo, esto sucede a pesar de los censores culturales o represiones del sistema que canalizan las ideas que circulan entre las masas. Así, el proceso de interculturación se mantiene, específicamente en los mercados, los campos militares y las casas (sobre todo en el campo) (“Contradictory...” Brathwaite 16-7).

Igualmente, el discurso brathwaiteano añade que la criollización se desarrolla de acuerdo con los modos de vida que se dan en las islas: en los hábitos de hablar y de pensar que circulan en ambas direcciones entre el blanco y el negro. También, el autor menciona el estilo entre los habitantes, refiriéndose así a cómo los blancos adoptan las costumbres de los negros, por ejemplo, en las maneras de vestir, en las comidas y en los bailes. ${ }^{121}$ Asimismo, las dinámicas sexuales e influencias amorosas entre las distintas culturas son la parte más importante y duradera durante la fase más larga, la de la interculturación (“Contradictory...” Brathwaite 19). Por consiguiente, dicho proceso

...in its turn, acted as a bridge, a kind of 'social cement' between the two main colours of the island's structure, thus further helping (despite the resulting class/colour divisions) to integrate the society... [an] interaction which must have had not only physical, but metaphysical effects as well. (21) 
Además, Brathwaite observa que la criollización sucede en una constante de espacio y tiempo que se clasifica en dos aspectos. El primero, la ac/culturación, es decir, el enlazamiento de una cultura con otra (ya sea por la fuerza o por el ejemplo, y que se deriva del poder o del prestigio). El segundo, la inter/culturación que se da sin estructura ni plan, más bien, es un proceso espontáneo que resulta de ese primer enlazamiento y que surge de una relación de influencia mutua (“Contradictory...” Brathwaite 6). Así la criollización, manifestada como proceso y no como producto, se convierte en norma cultural de la sociedad caribeña:

The creolization... becomes the tentative cultural norm of the society. Yet this norm, because of the complex historical factors involved in making it (mercantilism, slavery, materialism, racism, superiority/inferiority syndromes, etc.), is not whole or hard (crown: jewel: diamond), but cracked, fragmented, ambivalent, not certain of itself, subject to shifting lights and pressures. (6)

Por lo tanto, por sus complejos elementos históricos, esta norma cultural es frágil y maleable, y está sujeta a cambios y continuas presiones.

Brathwaite además pone de relieve distintas nociones que tienen correspondencia con la criollización. Entre las más conocidas está la palabra mélange (introducida por Handler) que se identifica más bien como '[a] personal, poetic statement’ (5). No obstante, la diferencia estriba en que su uso es estético y particular, en lugar de práctico y general. Por otra parte, algunos adjetivos se han adherido al concepto, tales como "creole creolization, mulatto creolization, incomplete creolization, lateral creolization, plural creolization,...”, entre otros (5). ${ }^{122}$ Según el ensayista, el problema que surge de estas denominaciones es que el lugar, estilo y contexto difieren, lo que limita la trascendencia del concepto. Esto es, los apelativos 
que podrían acompañar el concepto de criollización restringen la posibilidad de identificar otros espacios y contextos semejantes alrededor del mundo en otras culturas. Por consiguiente, en este particular caso, "Caribbean environment demands its own style, vocabulary, its own norms... these demands (should) challenge the scholar/intellectual as deeply as they do the artists, and that this creole aesthetic cannot be adequately developed outside the Caribbean; not even the Caribbean themselves" ("Contradictory...” Brathwaite 5). Es decir, la aceptación y uso 'universal' del vocablo creolization depende de su adaptabilidad a realidades distintas en otros espacios alrededor del globo. Inclusive, dicho término se interpreta en Jamaica de modo distinto a la exégesis que adquiere en otras islas del Caribe, pues siempre hay distinciones y diferenciaciones de acuerdo con los contextos particulares de cada lugar.

Ahora bien, la idea del amasijo está implícita en el término de la criollización. La pauta inicial en el Caribe es precisamente la mezcla cultural, ya indicada, entre los negros y los blancos. No obstante, con el tiempo ese mélange se extiende a las interacciones con otras culturas, entre éstas, las nuevas olas de migración a partir de la emancipación de los negros. Estos nuevos grupos culturales contribuyen posteriormente con más elementos, formando aun mayor hibridez. Así, en algunas islas más que en otras, hay una fuerte influencia de chinos (Cuba), indios (Trinidad y Tobago) e, incluso, norteamericanos (Puerto Rico, Islas Vírgenes, etc.). ${ }^{123}$ Cada una de estas culturas desempeña un rol preponderante, responde e influye de acuerdo a sus propias tradiciones, manifestándose junto con otros elementos que se transforman para crear la base cultural actual del Caribe. De esta forma, Brathwaite advierte que esa construcción cultural se da a modo de collage o de montaje que funciona incluso como presagio de la actual necesidad de un acercamiento interdisciplinario para entender las 
complejas y múltiples partes que hoy (con)forman la cultura caribeña (“Contradictory...” Brathwaite 5).

De igual importancia para la configuración del concepto es el origen de la palabra ‘creole’ o criollo. Ésta proviene del verbo ‘criar'. Sin embargo, también se deriva de 'crear’ y asume las siguientes nociones: 'imaginar', ‘establecer', ‘fundar', 'instalar'. Además, Brathwaite indica que el término igualmente se refiere al vocablo 'colón', es decir, colonialista, fundador, instalador (10). Por otro lado, la noción de ‘criollo’ adquiere distintos significados en Latinoamérica. Por ejemplo, algunos afirman que proviene de la palabra “criadillo” que quiere decir sirviente. En general, el término alude al resultado de situaciones complejas en las que reaccionan la política colonial a raíz de las presiones externas de la metrópolis y los ajustes internos provocados por la juxtaposición de la autoridad y la mano de obra: blanco y no-blanco, Europa y colonia (multatto creole), europeo y amerindio (mestizo creole), en una relación culturalmente heterogénea.

Así, la criollización, en cualquier forma y contexto, es la interrelación entre los dos ya mencionados procesos: a/culturación e inter/culturación (“Contradictory...”, Brathwaite 101). Recordemos aquí que décadas antes Fernando Ortiz trabaja con la metáfora conceptual de transculturación. El escritor cubano establece una dinámica contrapuntística para explicar las variadísimas manifestaciones de la cultura cubano-caribeña. Ortiz dedica parte del texto a enumerar y analizar sinnúmero de elementos que, rítmicamente entrelazados, establecen vínculos entre las historias de las culturas negra, blanca e indígena. ${ }^{124} \mathrm{Al}$ igual que la propuesta de Brathwaite, la transculturación proyecta el interés por las formas cotidianas de vida en las que coinciden las culturas sin quedar ninguna supeditada a otra. Ambos autores reconocen los procesos de interculturación y aculturación. Asimismo, proponen una transformación conceptual para explicar un contexto caribeño. 
A pesar del intento de parte de la metrópolis por mantener la separación entre las distintas culturas, manteniendo divisiones entre los grupos raciales, la realidad es que tal disposición en el Caribe resulta contradictoria. Esto es, las relaciones individuales o personales traen nuevos e inesperados intercambios en las maneras en que cada grupo procede: "This slow, uncertain but organic progress [and process] (from imitation/ initiation to invention), evolving into ac/act/accent, style and possibility, is what we mean by creolization. It is within this context that the development of the society should be seen" (Caribbean Man... Brathwaite 21). Con esto, Brathwaite también menciona la importancia y el ejemplo de la ‘sociedad plural caribeña’ (término acuñado en 1955): “the conception of Caribbean societies in our literature reflects... instability, plurality, ambivalence, dependence. ... the social reality may be as much figment as fragmentation result of our apprehension of reality...” (4). Por lo tanto, la realidad social desempeña un papel preponderante ya que paralelamente cambia el escenario. Es un proceso que opera no solo entre los individuos sino también a nivel simbólico, pues ese contexto (que está siempre en movimiento) va permutándose a sí mismo, así como a cada uno de los habitantes. Conjuntamente, ese desarrollo depende de la evolución y resultado de la capacidad de aprehender dicha realidad. Así, la cultura se (re)forma de acuerdo a la historia pasada y presente, tomando en consideración que, “...by culture I mean the texture and life-style of peoples ... seen as dialectic of motion”. También, que la historia sea vista, “as achievement/failure, flux \& equilibrium; as catastrophe; or rather, as equilibrium and catastrophe” (“Methaphors...” Brathwaite 232; mi énfasis). Por lo tanto, la cultura es un conglomerado de imágenes que forman un todo:

....in the context we must try to understand the new world of the Caribbean the new world and the Caribbean - what explosions occurred to create the symbolic fragments of continents that we now call islands and inhabit: what destroyed the myth or fact or dream of el dorado, lost atlantis, prospero's drowned island, ponce de leon's fountain of youth ... these are all images that 
curl around our imagination and cling: the notion of some infinitely gentle, infinitely suffering thing ... ("Metaphors..." Brathwaite 232-3)

Por esto, se advierte que el ethos caribeño es móvil. Es decir, depende de la unión noaleatoria de los factores que lo forman, a los cuales mueve y sintetiza, desembocando en una criollización no estática, mas sin embargo con suficiente base para crear críticamente una identificación con los individuos en cada espacio. De ahí que aún exista diferenciación e igualdad, de acuerdo a las dinámicas globales que, de hecho, comienzan a generarse a partir del siglo XVI con la colonización europea en el Caribe.

\section{Criollización y globalización}

La globalización según Fazal Rizvi es resultado de las prácticas coloniales ("Mobile minds” 101). Rizvi aclara que se entiende en base a reconocer la 'relacionalidad', incluso más que la 'localidad’, ya que las ‘localidades’ se producen precisamente como consecuencia de lo global y de las interrelaciones históricas (112). Al igual que la criollización, la globalización se da de acuerdo a las relaciones de poder que surgen entre la metrópolis, la colonia y sus habitantes; también entre los medios y modos de producción que crean dichas relaciones. Por lo tanto, "Caribbean [is] a compelling space in which to consider postcolonial identities and the uneven processes of globalization” (Knepper 73; mi énfasis).

Por consiguiente, la movilidad es central para entender ambas, la globalización y la cultura latinoamericana, específicamente, la caribeña. Esto, ya que "la globalización y la cultura hoy día se combinan” (Hopenhayn 14). De este modo, ese movimiento, que tiene su raíz en el colonialismo, expresa variadamente los espacios culturales en cada uno de los territorios en América: “...colonialism expressed itself in different locations differently” (Rizvi 103). Es así que la historia de estos lugares resulta primordial, pues, “The imprint of colonialism on patterns of migrations and community relations is highly significant. ... Nor is 
it possible to understand previously colonized countries without understanding their colonial history” (104). De hecho, la criollización y la globalización surgen por procesos globales y, al mismo tiempo, son discursos constituidos por un imaginario social. ${ }^{125}$ En consecuencia, “Creolization, as a way to model these complex processes, allows us to reevaluate these images as the active material culture through which new social identities were forged" (Webster 223).

Por otra parte, tanto la globalización como la criollización se fundan con la colonización europea y en ambas acontecen la homogeneidad y la heterogeneidad (Rizvi 107), puesto que se entienden "in terms of interconnectivities and interdependence that stretch across time and space... in terms of mobility” (101). Esto es:

En América Latina tenemos también signos de doble cara. Una larga historia de mestizaje no asumido nos puede disponer a la apertura pero también al atrincheramiento. La interculturalidad nos recorre desde el primer cruce de miradas entre Colón y los nativos de estas indias occidentales, y desde allí no se detuvo. Pero siempre trunca, chingada, trasvestida, oscilando entre la melancolía por la unidad perdida y la asimilación entre nuevos y viejos mundos. Así también, la endémica negación del otro que recorre la región como estigma cultural (negación del indio, el pagano, el mestizo, el zambo, el negro, el campesino, el pelado, el marginal urbano, la mujer), puede reforzar los sesgos más excluyentes en cómo aterriza la globalización en América Latina. O inversamente, la conexión global puede abrir finalmente el debate sobre los tabúes que nos separan y nos confrontan. (Hopenhayn 14)

Así, la globalización en tanto devenir histórico toma forma a través de las manifestaciones contemporáneas (dentro de cada contexto).

Asimismo, Brathwaite define la criollización de manera paralela a cómo la globalización ha sido descrita. Esto es, ambas son proceso y resultado del acontecer histórico. Por cierto, al observar la criollización se denota una fusión que resulta en síntesis y que delimita la identidad caribeña. En este sentido, la globalización, de acuerdo a los parámetros que 
establece Rizvi, sirve de espejo de la metáfora caribeña: muestran la ilación entre las figuras de poder y los subordinados. Por consiguiente,

...in any colonial context, those processes are given material expression. In this sense, material culture encapsulates colonial experience. ... creole culture is an amalgam of different traits, creolization processes take place in the context of asymmetric power relations. Links with the past are maintained in opposition to the elite-sponsored trajectories of a dominant culture, and maintaining tradition thus carries with it an element of risk. Creolization is frequently, therefore, a process of resistant adaptation. What emerges from this process is not a single, normative colonial culture, but mixed cultures. (Webster 218) $^{126}$

En definitiva, la criollización es la mezcla que se da a través de la interrelacionalidad e interconectividad cultural, asemejándose así con las dinámicas de la globalización. Inclusive, la crítica ya ha señalado esto, aunque advierte que tal aseveración podría ser peligrosa: “one might argue that there is a certain danger in leaping to the conclusion that a theory of multiple identities is also a model for globalization” (Knepper 73). ${ }^{127}$ Así, por un lado, la propuesta de Brathwaite menciona el tema del elemento étnico como uno de los factores preponderantes de la criollización. No obstante, por otro lado, esto trata solo una parte que define la cultura del Caribe. Tal como lo expresa Rizvi, ${ }^{128}$ “ethnicity needs to be understood in terms of a politics of location, positionality and enunciation - not so much as a process of discovery of lost 'roots' but of construction of a 'new' or 'emergent' ethnicity, linked to contemporary social relations and to relations of power” (“The Arts...” 61; mi énfasis). Precisamente, Brathwaite, en su momento, hablaba sobre estas mismas relaciones de poder en el colonialismo del Caribe. Es ahí en donde intervienen varios factores, siendo el racial un eslabón adicional de esta cimentación metafórico-cultural caribeña.

\section{La realidad-ficción y la expresión espiritual: enajenación y desintegración}

Poco después del asesinato del dictador Rafael L. Trujillo en 1961, Juan Isidro Jiménes Grullón, escritor abiertamente declarado en contra del trujillato (encarcelado y expatriado 
durante dicho periodo), escribe La República Dominicana: una ficción (1965). Por ficción, el autor se refiere al relato oficial y a las consecuencias que surgen de éste. Por consiguiente, tal discurso, en los territorios colonizados, crea una "identidad auspiciada desde el poder [que] también se dio como farsa” (San Miguel 138). En este texto, el académico analiza la evolución histórica del coloniaje y del colonialismo en la isla, dividiéndola en tres “expresiones”: la política, la económico-social y la espiritual. El enfoque de mi investigación se centra en esas "expresiones espirituales de un pueblo [que] son un producto de las características bio-psicológicas que éste acusa y de la influencia que sobre el psiquismo ejerce el ambiente social” (Jiménes-Grullón 215). Para Jiménes-Grullón, la expresión espiritual combina elementos biológicos y psicológicos que revelan e influyen en la vida, transformando las maneras de pensar.

Con esto, el autor examina cómo, "En la primera centuria de la vida colonial en Santo Domingo, la diversidad de razas dio origen a expresiones psicológicas disímiles”. Añade que, "esta disimilitud se mantuvo intacta hasta el momento en que se plasmó la integración social” y que “No desapareció totalmente entonces. Pero comenzó a desvanecerse” (215). Considerando el ensayo de Jiménes-Grullón, ese desvanecerse se refiere a la desintegración espiritual-social. Esto es, la diversidad étnica crea desemejanzas que se mantienen en mayor o menor grado a pesar de existir una estrategia del sistema para integrar socialmente la sociedad. Estas dinámicas de mixtura racial hacen que surja y permanezca la heterogeneidad cultural. El ensayista también analiza la separación social que se da en la isla de acuerdo a las clases socioeconómicas. Específicamente, enfoca la cosmovisión del país centrada en una posición teológico-feudal y en las manifestaciones sociales y culturales.

Jiménes-Grullón advierte que cada grupo socioeconómico del país, sobre todo la clase media, revela cierta enajenación, “tanto en el plano ideológico como en el de las realidades 
concretas” (219). En cada una de estas clases, en cuanto a lo ideológico, intiman con el discurso o la ficción por encima de la verdad de los hechos. Por otro lado, los elementos reales forman parte de lo que está detrás de esa ficción que funciona como una especie de telón entre bastidores. Es decir, la verdad no se presenta directamente a los demás. Por lo tanto, aquello que no se muestra, igualmente constituye el armazón para el entendimiento de lo real: "The investment in a certain kind of rationality and in a particular understanding of the 'real' means that history's -the discipline's- exclusions are ultimately epistemological” (Chakrabarty 98). Así, la enajenación acontece ya que resultan amenazadas las estructuras coloniales y la cosmovisión que mantiene las disposiciones ideológicas, sus fundamentos y métodos.

Ahora bien, la enajenación y la desintegración operan como metáforas. Están presentes en las diferentes clases sociales, aunque en distinto grado en cada una de ellas. Por ejemplo, la dependencia económica que tiene la clase media de la burguesa hace que la primera rompa, por conveniencia, con ciertas ideas limitantes. En efecto, es por eso que la enajenación no se da de manera total en las clases media y alta (Jiménes-Grullón 219); como al contrario sucede con la clase pobre (los esclavos y sus descendientes) (221). Esto es, ocurre de acuerdo a las distintas condiciones enfrentadas por cada grupo, puesto que aun así todos los habitantes de la isla dependen de la cosmovisión colonial que rige al país (al menos a nivel simbólico). De modo que en las alusiones a las divisiones sociales, en particular la enajenación y la desintegración, en ambas, "la constancia de determinado género de vida lo empuja a la variación, a buscar compensaciones y desvíos” (Jiménes-Grullón 220; mi énfasis). ${ }^{129}$ Precisamente, estas variaciones resultan ser los fragmentos que van formando la cultura caribeña. Según Jiménes-Grullón, esto pasa para compensar la desgracia (enajenación) de los eventos que han florecido en la sociedad colonizada (desintegración). 
Por otro lado, aunque en el Caribe las distintas clases sociales comienzan a desintegrarse (siglo XVIII), según apunta Jiménes-Grullón, “existía una generalizada solidaridad -impuesta desde arriba- con el coloniaje” (223). ${ }^{130}$ Sin embargo, la enajenación sucede horizontalmente, es decir, no transcurre como la implantación del poder (desde arriba) sino que se experimenta en todos los niveles económicos, aunque en distintas proporciones. Por consiguiente, esto sobreviene porque "El colonialismo fue, pues, esencia del espíritu" (223). ${ }^{131}$ Así, la expresión espiritual se refiere al resultado de la desintegración cultural que es condicionada por el colonialismo; y del desplazamiento y la (trans)formación de la cultura caribeña propiciada además a través de la enajenación.

Con la aceptación de las estructuras políticas y socioeconómicas, y de la cosmovisión teológico-feudal del coloniaje, el terreno social cede el espacio a una configuración o síntesis de los mundos culturales asentados en las islas. Aunque el sistema intenta mantener la separación entre las clases, todas establecen, desarrollan y mantienen una relación directa e inevitable con el esclavo. Por eso se crea cierta adhesión a las disposiciones sociales y económicas del colonialismo, pues consolidan las interrelaciones e interconectividades entre los distintos grupos.

Ahora bien, aunque la sociedad caribeña se encuentra atada a dichas estructuras y fundamentos teóricos, “dentro de esta subordinación cada grupo social daba, lo biológicamente suyo. Y fue en la música donde se logró la síntesis” (Jiménes-Grullón 220). Por esto, a través del baile se manifiesta dicha compilación o criollización. Es decir, como evidencia tangencial de la mezcla cultural, más allá de lo racial, la música y el baile plasman este proceso, su movimiento, su efecto. Por lo tanto, el sistema (o la cosmovisión) es un factor unificador que está presente a pesar de fomentar la desintegración social (por eso la ambigüedad). Así, aun su arbitrariedad, la música y el baile son factores que reinscriben y 
negocian nuevas representaciones intersubjetivas que consolidan la síntesis y heterogeneidad de la cultura en el Caribe. Esto es ya que,

The process of reinscription and negotiation -the insertion or intervention of something that takes on new meaning -happens in the temporal break inbetween the sign,... in the realm of intersubjetivity. Through this time -lag [enajenación] -the temporal break in representation - emerges the process of... historical development and... historical discourse”. (Bhabha 274-5; mi énfasis)

Ese espacio de intersubjetividad en donde se propicia el enlace de las culturas recalca un nolugar. Es decir, se identifica una formación o movimiento cultural en un intersticio liminal que está abierto a la transformación, en este caso musical, mas aborda cualquier elemento que responde a una comunicación de los distintos sujetos -aquí culturales. Una vez las dinámicas en cada contexto (re)forman, en esa intersubjetividad, sus formas discursivas, es que se (re)inscribe o reconoce la representación de una nueva 'realidad'. Aquí, simultáneamente, están la criollización-integración y la enajenación-desintegración. La ambigüedad de la unión de estas nociones es posible porque surge en la liminalidad o, si se quiere, el caos. ${ }^{132}$

En consecuencia, la cultura caribeña retrata su heterogeneidad, la “mezcla de [distintas] partes de diversa naturaleza en un todo” (DRAE). De ahí la idea de configurar un conjunto con las partes que, en un principio, se mantenían separadas. Por consiguiente, el decurso del tiempo, su proceso y desarrollo histórico, unifica también los divergentes elementos. Así, el resultado es un concepto no-fijo que sintetiza sus componentes culturales. De este modo, el transcurso y el efecto son vistos como lo mismo y dependen estrechamente de ese movimiento para la disposición cultural en el Caribe. 


\section{Criollización y expresión espiritual-cultural}

En la década de los setenta Brathwaite y Jiménes-Grullón produjeron escritos que expresan metáforas que recíprocamente se asemejan y conectan. Aunque sus enfoques difieren, como el sistema colonial de los respectivos países estudiados, en ambos se advierte la compilación cultural de la sociedad caribeña. Por supuesto, éstos no son los únicos autores antillanos que trabajan el mismo tema para la época. ${ }^{133}$ No obstante, el autor barbadense propone que nombrar distintos conceptos para expresar la hibridez cultural en el Caribe es innecesario ya que todas estas nociones denominan y tratan los mismos procesos socioculturales. De hecho, la metáfora de la criollización ilustra esa unificación conceptual del mismo proceso o transcurso, aun su ambivalencia. Así, Brathwaite advierte: "the problem and reality of Caribbean culturation lies in its ambivalent acceptance-rejection syndrome; its psycho-cultural plurality” (“Contradictory...” 16). Por cierto, encontrar una metáfora que defina la manera en que se da la pluralidad cultural, esa aceptación y rechazo, depende precisamente de un componente psicológico o, por llamarlo igual que Jiménes, de un aspecto espiritual que comprende en sí mismo dicha multiplicidad interna y dinámica: “the underlying consistencies and internal cultural dynamism” (Mintz y Price 10). ${ }^{134}$

De este modo, la criollización es producto de la ambigüedad del progreso del régimen colonial en el Caribe, de un intento por integrar la sociedad aunque al final la desintegra, por esa disyuntiva o choque entre unos factores y otros, de fuerzas encontradas. Por esto se da la relación entre la expresión espiritual que explica Jiménes-Grullón con la propuesta de la criollización. También, la enajenación conecta con el término de Brathwaite. En ambos ensayistas, se remite a la interculturación de distintos grupos étnicos y sociales dentro del sistema predominante. Con esto, la enajenación se refiere a una distracción o falta de atención que ulteriormente propicia momentos transitorios o permanentes de interrelaciones 
que acentúan la dinámica entre la integración (como plan o máscara) y la desintegración (desorden o 'realidad'). Por lo tanto, es desacertado encomiar el proceso de criollización o la hibridez como espacios de integración cultural o identitaria puesto que éstos ocultan, disfrazan o disimulan una más aguda desintegración social.

Igualmente, Brathwaite y Jimenes-Grullón admiten que lo espiritual (lo cultural) se presenta tanto a nivel abstracto como tangible. Por esto, advierten que en la música se logra la síntesis: "Los ritmos africanos y su instrumental típico se extendieron, ganaron al criollo de la clase media y llegaron a ser bailados y cantados por los miembros de la burguesía. ¡La cultura del oprimido se vengaba así del dominio del opresor” (Jiménes-Grullón 220). Ambos autores establecen relaciones entre las manifestaciones musicales que se van creando en las islas y cómo éstas sirven para representar las dinámicas culturales de los respectivos espacios. Décadas más tarde, Benítez Rojo igualmente estudia cómo los ritmos musicales caribeños funcionan como expresión cultural. Para el autor cubano, cumple está función no solo lo musical sino también lo poético, ya que sugieren una zona de caos (Benítez Rojo 37). Para explicar estas dinámicas, el ensayista establece la expresión “de cierta manera”, describiendo un movimiento relacionado con lo caótico, lo no estático. Además, el escritor busca representar o identificar la cultura de modo semejante al concepto musical del polirritmo (ritmos iniciales desplazados por otros ritmos). Esto es ya que lo artístico (musical, poético,...) permite ilustrar los diferentes matices de lo percibido y comprendido del entorno (en patrones que se repiten).

A través del arte musical y del baile se aprecia una unión cultural en los distintos grupos sociales. Es cierto que no deja de existir una constante separación clasista, característico del sistema colonial, no obstante, no interrumpe el continuo amasijo: “De la mezcla surgió el folklore musical típico de la comunidad... La población aparecía subordinada a la estructuras 
coloniales y sus fundamentos teóricos” (Jiménes-Grullón 220). Así se da el acoplamiento de los ritmos e instrumentos típicos africanos, que a su vez reciben el impacto de la música europea. De dicha mixtura germina el folklore musical típico de la comunidad caribeña, "los bienes artísticos fueron, pues, expresión de [estos] varios factores” (220). Por eso, la música es fundamental para la criollización, puesto que "las más importantes expresiones culturales de la región son la música y la danza” (Benítez Rojo 363). Ambas representan lo que sucede concretamente en otros ámbitos de la cultura.

Asimismo, es a través de la música que se da cohesión entre las clases sociales en un nivel simbólico, pues, aunque las estructuras de la colonia y su cosmovisión rigen la vida colonial, el proceso de la criollización, en parte, surge gracias a la expresión espiritual que JiménesGrullón advierte, aquí específicamente señalado en esas aficiones musicales. En el plano de las ideas, como respuesta al colonialismo, se da la criollización brathwaitiana. Por eso, los autores nombran la expresión cultural (que para Jiménes-Grullón es social); proponen un sistema de moralidad colectiva que "dada la diversidad y endeblez de sus fundamentos, tuvo un carácter heterogéneo y precario” (Jiménes-Grullón 236). Así, ambos ensayistas recalcan un punto en común que aborda la importancia de un plano simbólico y literario, recordando que los modelos culturales también aparecen en una zona intangible de un espectro continuo (Caribbean Man... Brathwaite 4). Incluso, aunque fuese fijo o estático, la realidad concreta siempre transforma el entorno y viceversa.

Poder, mezcla cultural e identidad

La idea de la identidad en el Caribe es compleja, indeterminada e incompleta. Todavía hoy, la literatura de este espacio se mantiene en una búsqueda por definir dicha identidad, puesto que no se basa en elementos fijos y concluyentes. Por supuesto, esto está estrechamente relacionado con la pluralidad cultural en las islas caribeñas. Esta 
multiplicidad también surge debido a que los habitantes del Caribe apelan, entre otras cosas, a un binarismo entre el lugar de procedencia y el nuevo lugar en el que se establecen. Es decir, tanto el blanco europeo como el esclavo, al instalarse en el terreno caribeño (y así en mayor o menor grado en toda América), concurren en el sentimiento de añoranza del país de origen y con el nuevo apego a las tierras en donde han erigido su nuevo hogar: ${ }^{135}$ "the double relationship or dual loyalty... [arise within] the space they currently occupy and their continuing involvement with 'back home'” (Lavie y Swedenburg 15). Por consiguiente, todo intento de definir lo caribeño como unilateral es desatinado.

Ahora bien, al definir la cultura caribeña hay que considerar también que el sistema colonial en el Caribe desde el siglo XVI funcionaba conforme a la idea de lo panóptico en Vigilar y Castigar (1975) de Michel Foucault. Esto es, la formación de esta identidad se da bajo la subordinación del poder, pues,

El que está sometido a un campo de visibilidad, y que lo sabe, reproduce por su cuenta las coacciones del poder; las hace jugar espontáneamente sobre sí mismo; inscribe en sí mismo la relación de poder en la cual juega simultáneamente los dos papeles; se convierte en el principio de su propio sometimiento (Foucault 122). ${ }^{136}$

Por lo tanto, la sociedad caribeña se establece a través de la interiorización (lo “espiritual” en términos de Jiménes-Grullón) de las estructuras de poder que controlan la sociedad. Esa interiorización o síntesis espiritual no es más que otro modo de entender la enajenacióndesintegración que marca cierta ruptura-unión de las disposiciones antecedentes. El nuevo sistema sirve como "un tipo de implantación de los cuerpos en el espacio, de distribución de los individuos, unos en relación con los otros, de organización jerárquica, de disposición de los centros y de los canales de poder, de definición de sus instrumentos y de sus modos de 
intervención” (Foucault 210). Por consiguiente, “Siempre que se trate de una multiplicidad de individuos a los que haya que imponer una tarea o una conducta, podrá ser utilizado el esquema panóptico” (210). De esta suerte, la configuración de la cultura en el Caribe se define de acuerdo al establecimiento del poder bajo un diseño panóptico y se relaciona con la imagen metafórica de la desintegración social como modelo de la cultura caribeña. Así, las distintas formas de evasión de ese sistema producen el sinnúmero de posibilidades culturales resultantes.

Por eso, lo panóptico genera un espacio intersubjetivo que admite la imposiciónintegración del poder. En ese sistema y en los movimientos que surgen, la mirada panóptica es la que impone el control y la que representa una búsqueda de la integración de dicho poder. De ahí que 'integrar' constituya un disfraz metafórico como lo es el proceso de hibridez o criollización. Tal como indica Kelly Baker Josephs en "Versions of X/Self: Kamau Brathwaite's Caribbean Discourse”, la idea del ensayista y poeta barbadense se centra en querer nombrar el proceso de la hibridez en el Caribe. Sin embargo, ese proceso es producto de las imposiciones que el esquema colonial propicia. Una de las mayores aportaciones de Brathwaite estriba en la manera en la que logra expresar la combinación de las diferentes culturas caribeñas junto con la conexión-integración de los distintos discursos: "not only does he combine aspects of different cultures -Caribbean, African, Amerindian, American [Chinese and Indian] -but he also combines different discourses- literary, historical, sociological -to create mosaic writings in poetry and prose” (Baker Josephs 13). Así, la contribución de Brathwaite es haber observado dichas combinaciones y conexiones sin caer en una mezcla desordenada de ideas. Al contrario, su concepto representa la capacidad de reunir las imágenes del proceso cultural caribeño y su tradición. Esto es, 
Caribbeanness is not some insubstantial, inexplicable connection between the people living in the region; rather it is specifically based in a shared experience. The sharing may not be conscious, but the idea is to make it conscious, to protect it by stating/naming it. Brathwaite's work attempts to produce this statement of unity. (Baker Josephs 3)

Con esto, la criollización se basa en una experiencia compartida que, aunque no sea consciente, al nombrarla se expresa la concientización que ulteriormente establece esa unidad en el Caribe.

A modo de desenlace, los conceptos que Brathwaite y Jiménes-Grullón desarrollan se derivan de sus respectivos estudios socioeconómicos de la cultura en Jamaica y República Dominicana. Ambos trabajos concuerdan con los distintos contextos de las demás islas del archipiélago. En el Caribe se interrelacionan todos estos aspectos sociales, culturales, económicos y políticos, superponiéndose unos a otros y moviéndose hacia distintas direcciones. Es cierto que en cada uno de estos espacios insulares los resultados varían. No obstante, todos estos componentes se trazan en el paradigma de la pluralidad en el que no debe existir un intento por conciliar valores y elementos comunes. Por eso, Brathwaite advierte que para hallar una definición de la cultura caribeña hay que desprenderse de cualquier división fija; de ahí se advierte el carácter retórico de sus ensayos.

Por otra parte, la criollización como resultado y proceso del colonialismo reproduce la globalización. Inclusive, la criollización ha sido vista en el Caribe como metáfora por otros académicos caribeños. Por ejemplo, el martiniqués Edouard Glissant utiliza esta figura conceptual para definir el espacio antillano y la unión aleatoria de sus elementos culturales. Sin embargo, su enfoque se centra en cómo esta representación se da sobre todo a nivel lingüístico. El siguiente capítulo analiza el concepto glissantiano, ya que la metáfora de 
Brathwaite al igual que los acercamientos hechos por Jiménes-Grullón apuntan a un reconocimiento inicial y anterior a Glissant de este continuo cultural creado en el Caribe. Por eso, aquéllos, con la criollización o la expresión espiritual anticipan un efecto-espejo de la globalización. La globalización surge de un mismo proceso histórico, con manifestaciones particulares contemporáneas que son consecuencia del colonialismo: “...colonial histories have affected the patterns of global flows ... the historical roots of colonialism involved trade and economic exchange that over time became asymmetrical” (Rizvi 104). 


\section{Capítulo 5:}

\section{Antillanité y créolité: el lenguaje créole como símbolo cultural caribeño}

" $L$ 'Antillanité ne nous est pas accessible sans vision intérieure. Et la vision intérieure n'est rien sans la totales acceptation de notre créolité" (Chamoiseau, Confiant y Bernabé, Éloge de la creolité 26).

\section{El créole en el Caribe}

El Caribe además de reconocerse como un área de debate sociopolítico y económico desde la colonización europea, entre otras particularidades, igualmente se distingue por poseer comunidades diglósicas. ${ }^{137}$ Es decir, cada una de las lenguas habladas en las distintas islas representan los diferentes sectores en la sociedad; muestran la separación lingüística entre el idioma oficial que se utiliza en las instituciones de poder y los demás lenguajes. Huber Devonish en Language and Liberation (1986) examina las dinámicas de los lenguajes que conviven en las islas caribeñas. En específico, su trabajo advierte cómo los conflictos de clases se articulan a través de las políticas lingüísticas de un país en donde la diglosia es la norma. El académico guyanés desarrolla su teoría con la intención de plantear una clara relación entre las funciones de los idiomas que coexisten en una nación y la política de la lengua oficial, por un lado, y, por otro, los sistemas económicos y sociales en los que concurren. El propósito del autor es crear un proyecto efectivo para la liberación política y económica de las islas a través de la oficialización del idioma créole o criollo, ${ }^{138}$ hablado por gran parte de la población en el Caribe.

En su trabajo, Devonish precisa acerca de la creación del créole y el contexto histórico en el que se forma. En un principio, detalla que el idioma se formó debido a la gran cantidad de esclavos africanos traídos por los colonizadores europeos a América desde del siglo XVII hasta el XIX. Como llegaron desde distintas zonas de África, existió una considerable variedad lingüística. No obstante, de acuerdo a Mervyn C. Alleyne, a pesar de existir tal 
diversidad de lenguas entre la población africana, aún hubo una subyacente unidad en el lenguaje. Esto es primordialmente ya que los esclavos pertenecían a la zona de una misma familia lingüística, la de Nigeria-Congo: “Thus, while African languages brought to the region presented a partial picture of diversity, particularly in their vocabulary and superficial syntactic features, they shared a lot in common in the area of phonology, semantics and underlying syntactic features” (Devonish 41). Incluso, aunque los idiomas dentro de la población africana se asemejaban, se desarrollaron en América y el Caribe patrones de diferenciación lingüística y, por ende, social.

El créole-génesis

Los estudios lingüísticos sobre el origen del créole dieron inicio hace cientos de años. Las investigaciones buscaban explicar cómo surgen estos idiomas, todos denominados como créole, al igual que las razones del por qué, aún separados unos de otros, simultáneamente, se formaron tan similares. En la década del setenta, Derek Bickerton examina distintas teorías sobre el surgimiento de las lenguas créoles y, además, propone su propia hipótesis. Su interés inicial fue el desarrollo de la lengua créole en Hawaii. No obstante, luego abarcó las zonas caribeñas y, después, otros espacios fuera del Caribe. Por supuesto, es esta relación que existe en los idiomas créoles de todo el mundo lo que posteriormente lleva a Bickerton a desarrollar una hipótesis en la que propone cómo el entendimiento del cerebro humano tiene la capacidad biológica de crear un nuevo idioma de acuerdo a un contexto y condiciones específicas. Así, concurren elementos sociales e históricos afines: una lengua de superestrato, la del colonizador; un idioma de sustrato de origen africano y las condiciones de trabajo en el sistema de la plantación.

Desde siglos se habían planteado ideas que revelaban un interés particular por saber acerca del génesis de estas lenguas. Glenn Gilbert indica que desde 1770 se reconoce la 
existencia de similitudes en el idioma créole a pesar de sus diversos orígenes. Según Gilbert, con la escritura de la primera gramática del créole de las Islas Vírgenes, por J.M. Magens, se reconoce un primer problema. Esto es, se hace referencia al créole como una variedad de idiomas en el Caribe y que, por lo tanto, "they cannot understand each other” (Gilbert 16). Un siglo después, varios lingüistas no solo admiten las mutuas similitudes sino también sus disparidades. Añaden además otras características que reconocen, por ejemplo, que la gramática del créole es mas básica o simple que la de las lenguas de las que se derivan ('lexifier') o incluso que cualquier otra lengua no-créole.

De ahí se forman tres ideas generales sobre los posibles enlaces lingüísticos en el idioma. La primera es la afirmación de un sustrato lingüístico en común (1883). Esta es conocida como la teoría monogenética y asume que todos los créoles tienen un ancestro genético único proveniente del portugués del oeste de África. Recordemos que Portugal colonizaba países de este continente al momento en que las colonias en América se abastecían de esclavos negros vendidos precisamente por los portugueses. Esta teoría facilita las explicaciones de las similitudes existentes en todos los idiomas créoles. ${ }^{139}$

Por otro lado, en el siglo XIX surgen las otras dos propuestas de la formación del créole. Una asevera la existencia de unas leyes universales, psicológicas y fisiológicas que desarrolla el ser humano. Ésta influye grandemente en la proposición posterior de Bickerton. El enfoque de esta idea es la experiencia y comportamiento del individuo, opuesto a las interacciones sociales de los grupos. ${ }^{140}$ Particularmente, observa la posible trasmisión de características y capacidades lingüísticas adquiridas genéticamente. Sin embargo, un tercer acercamiento observa la existencia de interacciones culturales y limitaciones sociales universales que suceden en la creación de un nuevo lenguaje. Afirma entonces que los cambios típicos gramaticales del créole son producto del forzado y rápido encuentro e 
interacciones de personas y culturas, que ocurría mayormente en el contexto de las plantaciones tropicales de los europeos en varias partes del mundo (Gilbert 17). ${ }^{141}$

Esta última propuesta sobre el créole pone de relieve las diferencias entre un idioma simplificado, o pidgin, y el créole. Roger Hall en 1966 se enfoca en la adquisición de un idioma en grupos de personas en lugar de observarlo individualmente (entre aprendiz y hablante). Para Hall, el proceso de criollización de un lenguaje implica la transformación de una lengua por otra a través de un grupo social, es decir, de pidgin a créole: "Creolization is thus conceived of first and foremost as an alteration in the social status of an antecedent pidgin. ... The nature of social interaction regulates [thus] creolization” (Gilbert 17). De ahí que las dinámicas que por las interacciones sociales se crean pasen a ser factores determinantes en el proceso de creolización, tanto en lo lingüístico como en lo cultural. Posteriormente, Bickerton describe más a fondo esas diferencias que Hall señala entre el idioma simplificado y el créole. De modo general, detalla cómo el cambio del pidgin al créole se daría a partir de un individuo (específicamente de un bebé) que posee, como todo ser humano, la capacidad de crear un idioma en un contexto determinado. El idioma que recibe ('input') de parte de los adultos que rodean a ese individuo-infante es un pidgin (mismo que funcionaba como segunda lengua para los padres-esclavos). ${ }^{142}$

Ahora bien, en general, a comienzos del siglo XX existían particularmente tres teorías en conflicto sobre la formación del créole. Algunas directamente tomadas de las antes mencionadas. La primera hipótesis es llamada la del superestrato. Esta teoría observa el lenguaje créole solo como un dialecto derivado de cualquiera de las lenguas europeas que han dominado en el lugar y el tiempo en cuestión (de acuerdo a la historia de cada una de las colonias). Por otro lado, otra teoría es la del sustrato que explora la idea de que, aunque el vocabulario del idioma créole se toma eminentemente de la lengua dominante europea del 
colonizador, gran parte de la estructura gramatical no es de influencia europea sino de una estructura marcadamente similar a la de las lenguas africanas. Ulteriormente, la tercera proposición lingüística sobre la formación de los créoles es la teoría antes indicada del monogénesis. Ésta menciona que las gramáticas de todos los créoles tienen destacadas similitudes (sin que la distancia física haya afectado dichas semejanzas). Considerando esto, los mono-genetistas han propuesto hipótesis que exploran las ideas de que las lenguas créoles provienen de algún idioma "madre de todos los créoles”, un lenguaje -proveniente de una mezcla afro-portuguesa -desarrollado en África occidental hace cinco siglos y que, luego, se haya extendido a través de la trata de esclavos. Así, su vocabulario fue cambiando al mismo tiempo que la lengua viajaba a las distintas colonias, manteniendo una estructura básica intacta.

Sin embargo, la propuesta de Bickerton, “The language Bioprogam Hypothesis”, examina la compleja relación entre la naturaleza biológica del ser humano y las circunstancias históricas en las que debe adaptarse. Para el lingüista, el cerebro de la especie humana está preparado para la creación de un nuevo lenguaje cuando las condiciones son impulsadas por las dinámicas sociales y económicas que se crean en las sociedades de plantación. La investigación del académico denota que entender la génesis de estos idiomas criollos (por sus semejanzas) permite una mirada exhaustiva a ciertas funciones genéticas-lingüísticas del ser humano. Es decir, el estudio de Bickerton supone que un individuo nace con la capacidad biológica de crear/programar un idioma para poder comunicarse. Conocer el origen del créole podría revelar entonces que la mente humana es capaz de crear un desplazamiento lingüístico que eventualmente permitiría la comunicación efectiva y, con esto, la supervivencia individual y social de una cultura que esté en desarrollo. Como sucedió en ciertos territorios en donde el sistema de la plantación dominaba las formas de vida. 


\section{Los créoles}

Conforme a lo indicado, se enumeran aquí múltiples créoles que coexisten en el espacio geográfico caribeño, particularmente, los que tienen mayor número de hablantes. De una parte, están los idiomas influenciados por el francés, como el antillano (Kréyol) que se habla en La Guadeloupe, La Martinique, Trinidad y Tobago, Guyana francesa y el créole haitiano; además está el créole con léxico francés de las islas de Lucía y Dominica. ${ }^{143}$ Por otro lado, la situación lingüística de St. Vicente y las Granadinas difiere, ya que el créole hablado en estas islas ha sido influenciado tanto por el francés, el español, el portugués y, ulteriormente, por el inglés. Inclusive, también se influyó por idiomas indígenas como el garífuna. De otra parte, en Granada se hablan dos formas de créole: uno influenciado por el inglés y el otro por el francés (como sucede en una parte de la población de Dominica). De modo distinto, en las islas de Barbados, Jamaica, Antigua y la Guyana inglesa se habla el créole con influjo del inglés. ${ }^{144}$ Aquí, existen regiones en las que el créole ha ido transformándose según los idiomas oficiales que las distintas regiones han adquirido. En particular, en las Islas Vírgenes de San Tomás y Santa Cruz, que inicialmente desarrollaron un créole holandés (siglo XVIII), luego repercute el inglés. Otra forma de créole que se afecta tanto por el inglés como por el holandés es el sranan o 'taki taki', hablado en Surinam. ${ }^{145}$ Por el contrario, aunque también con base de influjo holandés, toma protagonismo tanto el portugués como el español en la formación del créole de las islas de Aruba, Bonaire y Curaçao, llamado papiamento. ${ }^{146}$ Así, concurren incluso más variaciones del créole en el Caribe, no obstante, para el propósito de la presente investigación no es necesario nombrar ejemplos adicionales.

Ahora bien, la historia del lenguaje créole en los distintos países caribeños difiere de acuerdo a las diferentes dinámicas que surgieron a partir de la colonización y de la procedencia de los colonizadores. Sin embargo, aunque suscitaron distinciones históricas, 
económicas, políticas, culturales, etc., en muchas islas la realidad lingüística coincide. Esto es que se da la formación de nuevos idiomas a partir de la interacción con otros: los lenguajes africanos traídos por los esclavos $\mathrm{y}$, eventualmente, los idiomas que llegan por los trabajadores por contratos ('indenture’) que venían de India o China, entre otros. Con esto, el nacimiento del créole vislumbra la creación de una epistemología de la criollización/hibridez en el Caribe que surge a partir de la morfología lingüística de cada créole. En fin, la combinación cultural que se desarrolla en el espacio del Caribe se refleja en la forma, alteraciones y mutaciones que experimentan sus respectivas lenguas.

\section{Políticas del lenguaje créole: diglosia}

Una de las situaciones que Devonish recalca es que ningún créole en las Antillas caribeñas ha desarrollado ninguna función en las instituciones coloniales. La administración política, el sistema legal, los cuerpos legislativos y de asesoramiento en la colonia eran exclusivos de los blancos y de sus respectivos lenguajes europeos (Devonish 43). Así, trasluce que la división de idiomas funciona como símbolo de poder en las clases sociales dominantes. El lugar que ocupa el idioma refleja el complejo proceso cultural de los habitantes de cada isla. Su nacimiento o génesis, su proceso histórico, su desarrollo y lugar en la sociedad, proveen imágenes que sirven simultáneamente como conocimiento de la cultura del Caribe, en general y en particular.

Un ejemplo específico de las dinámicas lingüísticas mencionadas data desde 1791 en Haití. Al fraguarse la revolución haitiana, "It performed an ideological function, operating as a symbol of the emerging French speaking elite vis a vis the mass of the population who were speakers of Creole and/or African language” (Devonish 45). Todavía en el siglo XX, en esta isla, "The Creole language was a central component of the authentic black Haitian national identity which Duvalier and those who shared his black consciousness position wished to 
promote” (Devonish 58). No obstante, aunque el gobierno cedió un reconocimiento oficial al idioma créole, su implementación fue meramente simbólica. Funcionaba para reafirmar el dominio del grupo que formaba parte del gobierno, la clase adinerada y la nueva burguesía, de cara al resto de la población, pretendiendo aceptar el lenguaje de la masa como símbolo popular válido. Mas en la práctica no fue así, ya que la barrera del lenguaje servía convenientemente para continuar excluyendo la clase pobre de los procesos políticos (59). Asimismo sucede en gran parte de las islas en el Caribe, se consolida la separación de las clases sociales y se conserva el poder en manos de la elite.

En su libro, Devonish enumera algunos patrones que demuestran que el lenguaje es un medio vital para el proceso de producción en cualquier sociedad. Esto es, es un elemento primordial para la base económica de un país. Su uso organiza y coordina el proceso de productividad mercantil. Además, es el recurso que posibilita el conocimiento que crea y mantiene la economía: con el idioma se almacena y traspasa el saber unos a otros. En consecuencia, las relaciones sociales y su reproducción también dependen del lenguaje, protege las instituciones y, en general, toda la estructura de la sociedad (Devonish 16).

Dicho esto, la diglosia dificulta la economía de un país. Así, las formas elementales de producción se obstaculizan. Por ejemplo, si miembros de la clase baja pretenden participar en áreas importantes de la sociedad (educación, gobierno, salud, etc.) deben hacerlo prescindiendo del derecho de utilizar su lengua materna (créole). Por lo tanto, ese acceso resulta difícil e incómodo para ellos. De acuerdo a Devonish, esto constituye una ofensa de los derechos humanos (17). Igualmente, la diglosia no solo afecta a la clase trabajadora sino también a la clase dominante y las instituciones. Esto es, la clase popular, que no habla ni escribe el idioma oficial, no puede desenvolverse más allá de las destrezas básicas. Por lo tanto, no se le reconoce la posibilidad de ofrecer a la sociedad la cabalidad de sus 
capacidades. Al mismo tiempo, tampoco se desarrolla un canal de comunicación efectiva si la masa no entiende a sus patronos y viceversa. Dicho de otro modo, las políticas que mantienen el predominio de un solo idioma oficial, a pesar de proveer y reservar ese acceso al poder y a las instituciones para una minoría, ratifica las dinámicas sociales desiguales (Devonish 18). Entonces, esas desavenencias impiden el crecimiento rápido de la economía en la sociedad.

Aún estas condiciones, la mayoría de las islas caribeñas que han logrado su independencia han decidido mantener el lenguaje oficial del pasado régimen colonial. De este modo, se utiliza como herramienta simbólica e ideológica del poder. La clase dominante que ocupa las esferas políticas y económicas del país son quienes tienen acceso a la educación en el idioma oficial y quienes pueden manejar el poder a través de las instituciones. Así, conservan su estatus sobre aquellos que no dominan dicha lengua oficial. Por ende, la diglosia prevalece y se perpetúa la disparidad entre los grupos sociales.

\section{El ser del lenguaje}

Al estudiarse los lenguajes en una cultura se consideran, entre otras cosas, sus funciones en la sociedad en locuciones tanto habladas como escritas. En algunas islas caribeñas, la lengua oficial no es un idioma materno para gran parte de la población. Por un lado, la forma escrita del lenguaje oficial no es conocida por todos los habitantes, pues, es adquirido por una gran mayoría como un segundo idioma, oralmente, y sin la formalidad de la enseñanza

escolar. Por otra parte, además el créole es el medio diario de comunicación privada de muchos. Cabe señalarse que en algunos países se han creado modos de ortografía créole (como es el caso de Haití o el de algunas islas que hablan el créole con léxico del francés). Sin embargo, existen múltiples grafías que oscilan de acuerdo a la procedencia del sistema de escritura que se haya escogido utilizar. ${ }^{147}$ Según Devonish, estas diferencias entre las 
funciones de los lenguajes y su manejo no son convenientes, sobre todo, para la expresión de la creatividad, iniciativa o productividad entre los miembros de las comunidades (Devonish 35). Por lo tanto, la imaginación queda limitada y se obstruye así la libertad de articular las tantas posibilidades de la creatividad.

Así las cosas, el académico coincide con lo que Maurice Merleau-Ponty establece en sus postulados en Filosofía y lenguaje. Esto es, que "El hombre,... solo puede presentarse al mundo y a los demás gracias al lenguaje, y quizás el lenguaje sea la función central que construye una vida... que transforma en motivos de vida hasta nuestras dificultades del ser" (El arte de bregar Díaz-Quiñones 38). De este modo, hay una conexión entre la construcción de un lenguaje y su eventual evolución. En particular, se crea un vínculo que forma consciencia de la identidad nacional. Así, esta concepción cultural constituye una de esas 'dificultades del ser', surgen a raíz de los conflictos que pasan indistintamente de lo individual a lo plural, de lo privado a lo público. El desarrollo de un idioma abarca, por ejemplo, situaciones que configuran las experiencias en un grupo y que se conciben desde y hacia una innegable consonancia social. En específico, en países en los que se vivieron siglos de régimen colonial y que, eventualmente, comenzaron a adoptar nuevas políticas, afloran coincidencias sobre sus 'dificultades del ser'. Esto resulta en el todo (el conjunto) y, al mismo tiempo, en un fragmento de la identidad individual caribeña.

Entonces, estos conflictos y sus efectos, que iniciaron con el régimen colonial, son parte de la realidad pasada y presente del ser caribeño. En el Caribe y en América desde el comienzo del colonialismo se estableció disparidad entre los grupos sociales y, por lo tanto, en su manera de relacionarse con el poder. Por esta razón, las funciones que el lenguaje ocupa en estos espacios postcoloniales también son parte del ser. Aquí, es oportuno señalar el concepto provisto por el académico Walter Mignolo sobre la 'colonialidad del ser' en 
referencia a las funciones del lenguaje. Este señala que "los espacios conflictivos de enunciación que se generan en las formas de concebir prácticas culturales [están] asociad[o]s con la lengua” (Mignolo 9). Esa correlación es debido a que, a partir de "las condiciones históricas que operan en la relación entre sujeto, su suelo y horizonte simbólico,... la lengua es un componente fundamental” (Mignolo 30). De este modo, el idioma créole, su formación y todas sus implicaciones, funciona de acuerdo a lo que Mignolo llama práctica cultural y, por eso, sirve igualmente como metáfora de la cultura del Caribe.

Ahora bien, el lenguaje como práctica simbólico-cultural es una de las partes conflictivas de la 'colonialidad del ser'. Como tal, sirve como modelo del ser caribeño y de su cultura. Esto es, en el idioma, considerando que igualmente funciona como 'lugar' en “donde conseguimos amparo y donde moramos” (Mignolo 23), es donde se anida el ser. Por lo tanto, tanto la lengua como la casa son "portadora[s] de un compendio diverso, pero ordenado, del saber cultural y social” (Mignolo 22). De esta suerte, la lengua como casa simbólica del ser sirve de representación epistemológica de la cultura, aquí específicamente del Caribe.

El lenguaje (el 'decir' para Mignolo), “incorpora lo ajeno a su propio horizonte simbólico” (30) y lo convierte en propio. Esto sucede para que un idioma continúe su desarrollo 'regular' o, dicho de otro modo, para que sobreviva (en el caso del créole conviene mirarlo a partir de su génesis). Así, de igual forma que existe la incorporación de lo ajeno en una lengua, sucede igual en la cultura, sobre todo, cuando existe una lucha de poder entre distintos sectores de una sociedad. En el contexto colonial, “... si la cultura es una praxis y una manera de encontrar estrategias para vivir, y el decir [, o el lenguaje,] es parte de esas estrategias”, ésta admite que se trata de un modo “de política cultural” (Mignolo 30). En otras palabras, son maneras de articular las dinámicas que resultan de las interacciones 
públicas y sociales. Por lo general esas relaciones llevan a ilustrar cómo "la cultura [funciona] como praxis de creatividad y sobrevivencia” (Mignolo 10). Habría que recordar que la creatividad es apertura y, como se ha visto en otros capítulos de esta investigación, también se vincula con el concepto de la libertad.

De otra parte, el espacio de las esferas públicas es compartido por todos los grupos sociales, por lo que es ahí donde éstos se relacionan entre sí. La posibilidad que un lugar público da para relacionarse es ambiguo, pues, al mismo tiempo que el sistema (ya sea represivo o liberal) tiene acceso a controlar dicho espacio, también los miembros de la sociedad tienen acceso a salir de sus respectivos círculos privados y así reconocer inquietudes semejantes entre la colectividad. De ahí que sea en el lugar público donde se reflejan las consecuencias de la imposición de un idioma oficial. Por ende, las dinámicas de las políticas del lenguaje en un país ilustran un espacio simbólico de lucha que incluye triunfo y fracaso.

Para recapitular las ideas de este apartado es pertinente indicar que el créole como metáfora de la cultura caribeña coincide con lo que Fernando Garcés distingue como espacios compartidos. En particular, que

Las identidades y las configuraciones culturales se forman, se van formando, en el juego y forcejeo político de definiciones de espacios de luchas de poder. $\mathrm{Y}$ en esas luchas se van ganando y se van perdiendo espacios. En esas luchas se tejen sueños, contradicciones y esperanzas. [...] La razón y la palabra no quedan fuera de esas luchas por ganar espacios de poder. Y esas luchas se dan en la frontera, en el límite, en el intersticio, en el espacio compartido entre los sectores de poder y los sectores subalternos. (Garcés 238)

Por consiguiente, que los distintos sectores de la sociedad compartan un lugar común advierte la apertura ya señalada. En fin, se abre la posibilidad para crear una resistencia multilateral para que el abuso del poder se menoscabe. En otras palabras, la situación lingüística que los distintos grupos sociales enfrentan dadas las correspondientes políticas que el lenguaje oficial 
manifiesta en un país, simboliza precisamente la tensión cultural distintiva del espacio caribeño.

\section{Le Discourse Antillais: la cultura a través del lenguaje en el Caribe}

La creación del concepto de négritude es uno de los primeros pasos que la literatura caribeña da en el desarrollo del pensamiento cultural del siglo XX. Como ha sido señalado al inicio de esta investigación, con Césaire y Ortiz se pauta un modelo cultural en el Caribe a partir de las ideas de raza y, por consiguiente, del mestizaje. De ahí que académicos y escritores de las Antillas hayan hecho una extensa crítica sobre el término después de su inicial aparición en la década del treinta. Uno de estos estudiosos es Edouard Glissant (19282011), quien concibe una teoría acerca de la caribeñidad: L’Antillanité. Esta sección considera los ensayos glissantianos, “Inconscient, identité, méthodes” y "Pour l’antillanité”, que forman parte de una serie de análisis publicados en 1981 en el libro Le Discours Antillais.

Uno de los argumentos de Glissant es que el lenguaje en el Caribe, de manera inconsciente, expresa la cultura antillana. Otra propuesta de sus ensayos es que se advierte una continuidad del modelo de la négritude a través de planteamientos que expresan una teoría más abarcadora de la identidad cultural en las Antillas. Glissant advierte que, aunque haya sido importante establecer la identidad de la población caribeña desde el pasado africano, desde la historia de la esclavitud en América, también hay que señalar y relacionar otros elementos que conforman esta (nuestra) realidad.

La metáfora de la antillanidad o caribeñidad propuesta por el autor martiniqués se ilustra por medio del lenguaje. En particular, éste señala cómo la creación del idioma créole funciona de modo efectivo para presentar las dinámicas culturales que surgen en el Caribe a partir de la colonización y los posteriores intentos de independización política, económica y 
cultural. Esta lengua funciona como tropo de lo caribeño, puesto que ilustra la relación ambigua entre el idioma de la metrópolis y su sistema, en general, y la existencia de una consciencia de dicha ambigüedad (incluso aunque la formación de un lenguaje, según Glissant, es en un nivel inconsciente). El créole es la imagen del proceso de (trans)formación de la cultura antillana: es la expresión de lo caribeño.

De esta manera, el créole marca una oposición deliberada contra el orden establecido. Esto es, de acuerdo al autor, “...s’y manifeste une volonté culturelle d’opposition, et, sinon contre l’ordre établi, du moins contre un ordre donné” (Glissant 478). Es decir, la manifestación de esta lengua es un símbolo de oposición cultural. Que hayan surgido nuevas formas lingüísticas, a pesar de las imposiciones del sistema colonial e, incluso, que hayan continuado esas prácticas luego del cese del régimen, valida esa resistencia. Por eso, el génesis del créole juega un rol primordial como parte de la formación de la identidad del Caribe, pues, entre otras cosas, incluso representa la comunicación efectiva en un grupo social. El colonialismo estableció dictámenes para mantener el sistema y dominar la sociedad. Sin embargo, la mera existencia de una disposición lingüística diferente a la europea como modo de expresión extraoficial es de antemano un enfrentamiento y sublevación contra el poder.

Efectivamente, Glissant indica que existe ambigüedad en la relación entre los idiomas francés (el oficial) y el créole. Por supuesto, esta indeterminación es resultado de la convivencia de ambos idiomas durante un largo periodo de tiempo y en un mismo espacio geográfico. Ahí, en lo ambiguo del créole y de su historia relacionada con el francés, particularmente en la comunidad martiniquesa, recae precisamente la falta de consciencia de la identidad (de la relación) cultural antillana de la que habla Glissant: 
si le Martiniquais a la prescience de l'ambiguïté de son rapport au français et de son rapport au créole, l’une: lange imposée, l'autre: langue non posée, c'est peut-être parce qu'il a l'obscur pressentiment qu'il lui manque dans son espace-temps réel une dimension fondamentale, qui est la relation antillaise (Glissant 479).

Para el escritor, se carece de un conocimiento de lo antillano, de la reciprocidad entre una y otra lengua, entre las culturas que se compenetran y relacionan en el espacio del Caribe. Asimismo, "Contre la liaison unilatérale à une Métropole, la multi-relation à la diversité antillaise. Contre la contrainte d'une langue, la propagation d'un langage” (479). El ensayo plantea aquí que, aunque la aparición del créole durante el colonialismo haya supuesto una refutación a la coacción del sistema, continúa una inevitable relación establecida entre dicho régimen y su sistema lingüístico con las nuevas formas criollas. La población antillana, resultado de las dinámicas coloniales durante tantos siglos, en su necesidad de comunicación, origina el créole (que de acuerdo a Bickerton inicia desde las primeras generaciones de esclavos en las sociedades de plantación). Así, eventualmente esta lengua sirvió en el Caribe como treta para los subordinados relacionarse. Se presentó como resistencia contra las imposiciones coloniales e incluso como una puesta en acción en el plano plural-colectivo.

De acuerdo a lo mencionado, las conexiones que surgen en el espacio caribeño suceden en un sentido inconsciente. Glissant señala que esto admite una dimensión perdida. Es decir, éste habla de una duplicidad del espacio y del tiempo, de uno real y otro imaginario. Además añade que lo caribeño muestra una proporción inadvertida entre esos espacios y tiempos en las Antillas. En particular, por un lado, el autor propone que el sentido del tiempo para el antillano difiere del de sus antiguos colonos, que tiene otro ritmo y que, por lo tanto, sirve para denotar una cadencia caribeña que difiere de otros espacios. ${ }^{148}$ En adición, para éste la 
geografía física juega un papel preponderante. La tierra, dado al espacio insular limitado, marca un exceso que no puede poseerse aun su circunscripción. ${ }^{149}$ Desde estas realidades, e igualmente a partir del imaginario, se crea una nueva cultura expresada en el reconocimiento, o bien el (des)conocimiento, de la interacción de todos estos elementos coexistentes. Esto es, aunque el créole se formó inconscientemente, ya una vez establecido y adoptado, se da un proceso de toma de conciencia, por ejemplo, con la implementación y evolución de dicha lengua (y que existan formas escritas del créole cada vez más avanzadas).

Según el pensamiento glissantiano, l'antillanité es una realidad frágil. Para el ensayista, se forma a partir de ciertos factores comunes y se advierte con la interacción entre esos componentes. No obstante, se recalca la falta de promover la experiencia compartida, de crear una expresión más consciente de sí (fuera de las esferas académicas). Glissant reclama que existe una necesidad de afirmación colectiva, particularmente a través del activismo comunitario: "Il manque a la l’antillanité: de passer du vécu commun a la conscience exprimée; de dépasser la postulation intellectuelle prise en compte par les élites du savoir et de s’ancrer dans l'affirmation collective appuyée sur l’acte des peuples” (Glissant 729). Así, a través de la expresión y la acción colectiva se posibilita la formación de una identidad cultural caribeña común. Por consiguiente, “l’antillanité relèvent... du partage et de la communauté, ...des espoirs débattus, ...de nos peuples avant tout” (Glissant 732). En la verbalización se pone de relieve la antillanidad, la participación de la colectividad; dicho de otra forma, la de toda su gente.

Como ha sido indicado, el discurso de la antillanidad propone la exploración de varios aspectos en la población del Caribe. Entre estos, los elementos africanos, aún cuando han sido modificados, siempre han estado presentes en nuestra cultura y sociedad. En cuanto a los componentes lingüísticos, desde sus orígenes hay una marcada variedad de las relaciones 
y las dinámicas surgidas entre todas las culturas que han convivido en las islas. Específicamente, el autor afirma que las dimensiones múltiples en nuestra cultura se representan a través de la lengua. De ahí que la crítica señale que la contribución mayor de Glissant ha sido precisamente ahondar sobre el tema del lenguaje en la literatura caribeña:

Glissant was certainly the first West Indian intellectual to stress the linguistic dimension of colonialism and the problem of diglossia in the islands. But more important than this analytical contribution is his stress on the relationship between the writer, his people, and language. ... his essential belief: language for the West Indian writer is the only way of shaping the future. (Condé 157)

Así, el lenguaje se fortalece o confirma a través de su multiplicación (pluralidad). Ciertamente, esto es lo que señala Glissant y lo que Maryse Condé reconoce del trabajo de éste. La escritora guadalupeña añade que, "Language is the cord which links the West Indian to this land, to his past, to his history. The cord which links the West Indian to the West Indian” (Condé 157). Por esa interconexión que logra la lengua, la misma sirve como símbolo que posibilita la formación de la identidad colectiva del espacio antillano.

\section{El créole: lo reformado, lo múltiple y lo total}

En 1989, un grupo de académicos caribeños redactan el conocido discurso Éloge de la creolité. Rafael Confïant, Jean Bernabé y Patrick Chamoiseau proponen una nueva mirada a varios textos de la literatura caribeña, entre los que está el trabajo de Glissant. Tanto en Glissant como en el Éloge..., se considera la importancia del idioma créole para la expresión de la identidad en el Caribe. No obstante, Glissant dirige su teoría señalando que la antillanidad abarca todas las islas caribeñas independientemente del lenguaje hablado en cada una (incluso si no se habla la lengua créole). En particular, Glissant se enfoca en una noción 
geopolítica centrándose en el espacio geográfico antillano. Por el contrario, los tres autores del Éloge... reconocen otros territorios fuera del Caribe que comparten las mismas dinámicas que se dan en pueblos que se forman bajo condiciones coloniales similares y que poseen una variedad del idioma créole. Así, los creolistas o criollistas extienden su idea fuera del límite geográfico, denotando solidaridad con otras regiones como Mauricio (Mauritius), Réunion, Hawái (Hawaii), Cabo Verde y Zanzíbar (Hayes 23-4).

A pesar de las diferencias mencionadas, respecto al enfoque dentro o fuera de la zona geográfica caribeña, Jarrod Hayes señala que ambos planteamientos son muy similares. En un principio el modelo de identidad manifestado en la creolité toma mucho del vocabulario que Glissant maneja en la teoría de l'antillanité. Sin embargo, "the créolistes’ complex reliance on a genealogical notion of filiation, in conjunction with an almost oedipal revolt against the forefathers” (Hayes 25). Es decir, los criollistas dependen de sus modelos ascendientes como la négritude y l’antillanité, aún cuando simultáneamente manifiestan cierto rechazo contra esa tradición literaria. Inclusive, éstos se declaran a sí mismos “as the culmination of this literary evolution” (24). Por lo tanto, resulta paradójico que estos autores criollistas, por un lado, elogien y reconozcan el valor del uso del créole como instrumento de expresión identitaria y, por otra parte, critiquen a estos escritores por utilizar el idioma francés para expresar su creatividad. Esto, porque ulteriormente Chamoiseau y Confiant escriben también en francés la mayoría de sus proyectos literarios (a veces lo fusionan con el créole).

Ahora bien, los tres autores reconocen que Glissant y Frankétienne ${ }^{150}$ facilitan a las nuevas generaciones la posibilidad de reconocerse a sí mismos, de lograr una visión hacia el interior del ser caribeño. Sin embargo, admiten que es un trabajo que todavía falta por hacer: "Il fallait nous laver les yeux: retourner la vision que nous avions de notre réalité pour en 
surprendre le vraie. Un regard neuf qui enlèverait notre naturel du secondaire ou de la périphérie afin de le replacer au centre de nous-mêmes” (Éloge... 23-4). Con esto, el proyecto criollista advierte que la cultura caribeña se percibe y se expresa a través de una mirada interna, de un regreso al créole. Se incluyen así los elementos históricos de los pueblos colonizados, en particular los del Caribe, en esa formación del lenguaje y en las disposiciones diglósicas que mantienen (como lo advierte Bickerton); es así un elemento más que aporta a la plétora del ser cultural caribeño: "Notre richesse bilingue refusée se maintint en douleur diglossique” (Éloge... 25).

En los apartados anteriores se discuten diferentes acercamientos acerca del idioma créole y cómo coinciden en entender la lengua como símbolo cultural en el Caribe. Por ejemplo, en el caso de l'antillanité de Glissant, incluso, “The concept was regarded as a new literary project, a re-evaluation and re-interpretation of Caribbean identity” (Salhi 14). Mientras que el término glissantiano traza una actitud que invita a la consciencia de una cultura múltiple y variada que surge de la relación entre la lengua y la cultura dominante (la europea) y las subordinadas, los criollistas no hablan de una 'relación’ sino de una ‘recomposición’. Para los tres ensayistas, se trata de una significación o representación en una sola figura que implique lo total de la cultura, es decir, la creolité: "La Créolité c’est «le monde diffracté mais recomposé », un maelstrom de signifiés dans un seul signifiant : une Totalité” (Éloge de la creolité, 27; énfasis de los autores).

Tomando en consideración lo indicado, el Éloge de la créolité además busca estipular un Nuevo orden en la literatura caribeña. Por eso Condé advierte que ese orden propuesto manifiesta o imagina los futuros temas literarios de modo limitante. Esa limitación atenta en contra de las ideas que se refieren al tema de la libertad y que está presente en muchas de las denominadas teorías de identidad cultural en el Caribe. Por consiguiente, la propuesta 
restringe las posibilidades, la creatividad, en la literatura: “... give the impression of... the emergence of a new order, [but] even more restrictive that the existing one” (Condé 159). Inclusive, según Condé, los criollistas circunscriben la imaginación de los escritores de la literatura antillana o criolla, específicamente, enumerando cuáles deben ser los elementos de la cultura popular según estos tres lo determinan (Condé 160). Condé añade además que con esta propuesta se mantiene y refuerza la tradición de la dominación masculina en la esfera cultural caribeña (Hayes 24).

Por otra parte, Confiant, Chamoiseau y Bernabé plantean que el créole debe ser la única lengua materna para expresarse en los territorios criollos y en sus literaturas (Condé 158). De acuerdo a estos, la utilización de dicho idioma supone un acto de reapropiación de uno mismo. Sin embargo, con esto la creolité pasa a ser una estética que responde y contradice la proposición de Glissant. Devalúa la relación que existe a raíz de las dinámicas que se dan entre el francés y el creole. ${ }^{151}$ No obstante, para los creolistas, el créole funciona como método para (re)apoderarse de su identidad (lengua = identidad).

Al exigir un único idioma para la literatura caribeña la libertad o la creatividad se limita. Sin embargo, precisamente mediante esa libertad de expresión es que la identidad puede reafirmarse. De ahí que Condé advierta que esta proposición es restrictiva. Además, por eso es que Glissant menciona que la forma geográfica del Caribe es abierta: representa así la libertad que permite crear reformas ('reshape') en la cultura (Condé 160). Igualmente, Devonish propone también la liberación de la cultura caribeña. Su ensayo estudia cómo las políticas de una lengua oficial mantienen la diglosia o la separación de las funciones de los idiomas en una sociedad. En sus planteamientos se establece que es contraproducente para una cultura que un solo lenguaje tenga prioridad (el oficial) en las esferas públicas. También propone que el créole debe ser utilizado de modo equitativo a favor del futuro de dicha 
lengua y, por lo tanto, de las clases sociales que la hablan. Evidentemente, en las tres propuestas se reconoce la metáfora del créole como modelo de lo caribeño. Estos ensayos se enfocan, desde distintas perspectivas, en cómo el créole sirve para ilustrar una realidad cultural en el Caribe. El créole funciona entonces como tropo que simboliza la historia de las relaciones de poder a partir de la colonización, la imposición del sistema colonial de la plantación, la represión frente a un idioma oficial de origen europeo y hasta la posibilidad de la libertad y creatividad en la cultura caribeña. 


\section{Capítulo 6:}

\section{El caos, la brega y el desorden en el Caribe}

\section{La relectura: repetición y caos caribeño}

En La isla que se repite (1989) el académico y escritor Antonio Benítez Rojo (1931-2005) observa cómo las teorías de las dinámicas repetitivas del caos funcionan metafóricamente para entender las relaciones culturales de las sociedades caribeñas. Estas comunidades coinciden, entre otras cosas, en que han sido influenciadas por lo que el autor denomina como el 'macrosistema' de la plantación. ${ }^{152}$ En este escrito el ensayista cubano tiene especial interés en abordar la cuestión de la identidad. Así, propone una relectura de este espacio, de “su fragmentación, su inestabilidad, su recíproco asilamiento, su desarraigo, su complejidad cultural, su dispersa historiografía, su contingencia y su provisionalidad” (Benítez Rojo 19). La reinterpretación de estas peculiaridades en el Caribe se consideran aquí a partir de su disposición geográfica. En particular, partiendo “[d]el hecho de que las Antillas constituyen un puente de islas que conecta 'de cierta manera', es decir, de una manera asimétrica, Sudamérica con Norteamérica” (20).

En primer lugar, los estudios acerca de la teoría del caos buscan regularidades que se repiten en donde hay un aparente desorden. De acuerdo a Benítez Rojo, esta teoría funciona como modelo conceptual (metafórico) del conjunto discontinuo del espacio antillano; de la unidad/diversidad caribeña. Erik Camayd-Freixas, en su ensayo "El fractal de Mandelbrot...”, advierte precisamente que, a través de este modelo teórico, Benítez-Rojo interpreta la cultura caribeña: “Es la aplicación de la epistemología del Caos a un nuevo modelo conceptual, a una nueva metáfora de la realidad (histórica, cultural, identitaria)...” del Caribe (33). Esto es, al observar las incertidumbres que surgen de "todo lo que se repite, reproduce, crece, decae, despliega, fluye, gira, vibra bulle”, se posibilitan conexiones y 
tránsitos interdisciplinarios; así como reconocimientos de procesos, dinámicas y ritmos manifestados en lo marginal, residual, incoherente, heterogéneo o impredecible (BenítezRojo 21). Las repeticiones insulares, según el escritor, tienen un sentido contradictorio, tal como sucede con las disposiciones del caos. Es decir, estas reproducciones marcan diferencias que al mismo tiempo conducen hacia la nada o en torno a lo imposible. Por esto se recalca que el archipiélago del Caribe no es común sino, más bien, “un meta-archipiélago y como tal tiene la virtud de carecer de límites y de centro” (Benítez Rojo 22). Es decir, este conjunto de islas es un enunciado de sí mismo: es un discurso sobre el Caribe. Ciertamente, la geografía antillana entonces actúa como epistemología cultural que representa su propio espacio. Por eso la cultura y el lugar en donde bulle, el archipiélago, son discursos. Por lo dicho, lo caribeño no se remite a un punto de origen exacto como tampoco a un eje central.

Ahora bien, cabe señalar qué es lo repetitivo en el espacio caribeño. Como el autor advierte, se trata de series de movimientos que resultan de estímulos externos e internos. Resultan así cambios, retornos y flujos que "atraviesan la cronología de las grandes contingencias de la historia universal, de los... discurso[s] económico[s], de los mayores choques de razas y culturas que ha visto la humanidad” (23). De manera que para indagar efectivamente acerca del Caribe y su cultura, Benítez Rojo expone que no debe escogerse una sola ideología, sea premoderna, moderna o posmoderna. Éste indica que habría que hacerlo "desde un paradigma supersincrético" en el que se fusionen estos tres modos de interpretación. Sin embargo, aclara el académico que este acercamiento de acumulación de arquetipos, por otro lado, dificulta los razonamientos ya que, cualquiera de estas modalidades por separado, podrían resultar ajenas o desajustadas (15).

Al plantear el estudio del Caribe desde varias perspectivas o acercamientos, Benítez-Rojo defiende la idea de que las relecturas de este espacio son necesarias. Esto, en un primer 
ámbito, ya que hay diversas prácticas culturales en todo el archipiélago. Asimismo, el escritor afirma que se trata de una especie de ensamblaje de 'máquinas’. Específicamente, “de una máquina que debe verse como una cadena de máquinas acopladas... donde cada una de ellas interrumpe el flujo que provee la anterior. Se dirá, con razón, que una misma máquina puede verse tanto en términos de flujo como de interrupción...” (Benítez Rojo 25). Entonces, es a partir de las relecturas que estas máquinas pueden entenderse, cada una con múltiples funciones. Por eso en su multiplicidad éstas sirven como tropo de lo automático. En particular, las máquinas muestran las ideas del movimiento perpetuo, repetitivo, autómata, mecánico, en fin, de lo que no tiene voluntad propia. De ahí que sean una representación efectiva de la masa que (re)produce cultura. Por ende, lo caribeño es parte del flujo de dinámicas, pero igualmente lo produce o genera. ${ }^{153}$

Ocupan también gran importancia en el escrito las ideas que se enuncian a partir de la expresión ‘de cierta manera’. Esto es, de acuerdo a Benítez-Rojo esta frase determina la asimetría propia de lo caribeño. Por un lado, la imprecisión que recalca el vocablo 'cierta' aporta a la ambigüedad de lo que es el Caribe: es algo que no tiene certeza, es una forma de “sabiduría simbólica, ritual” (29). Por esto, la ‘cierta manera’ no se entiende sino a través de aún más relecturas. Dicho enunciado requiere entonces de improvisación, concretamente, en la esfera cultural y en la formación de la identidad del Ser caribeño. En particular, Benítez Rojo se refiere a que, "Cuando la cultura de un pueblo conserva antiguas dinámicas que juegan 'de cierta manera', éstas se resisten a ser desplazadas por formas territorializadoras externas y se proponen coexistir con ellas a través de procesos sincréticos ... contribuyen[do] a aumentar el juego de las diferencias” (40-1). En otras palabras, la ‘cierta manera’ posibilita la coexistencia de los varios elementos que forman la cultura del Caribe; permite que, con varias lecturas, lo externo e interno redefinan el espacio y sus disposiciones. 
Desde el punto de vista del caos, las Antillas advierten un orden aunque éste sea impreciso. Esta imprecisión sucede por las constantes repeticiones del espacio y la cultura, puesto que sus efectos no resultan iguales. Por el contrario, repercute en distinciones que aumentan las posibilidades de significados de lo caribeño. Claro está, como "El Caribe es un mar histórico-económico principal y, además, un meta-archipiélago cultural sin centro y sin límites, [es en sí] un caos dentro del cual hay una isla que se repite incesantemente, cada copia distinta-, fundiendo y refundiendo materiales etnológicos...” (Benítez Rojo 29). Esto, junto a los demás elementos que lo conforman. Por lo tanto, las relecturas son las que permiten miradas escrutiñadoras de cada isla y de cada elemento, en la incesante cadena de significantes. Para lograrlo hay que distinguir los variados componentes culturales por separado. Así, "se produce al momento el desplazamiento errático de sus significantes hacia otros puntos espacio-temporales, ...” (31-2). Al denotar esto, se producirán otros desplazamientos o “fuga[s] caótica[s] de significantes, y así ad infinitum” (32).

Para efectos de la presente investigación, la mirada a lo caribeño desde el caos interesa en cuanto a cómo la cultura puede ser vista como metáfora. Ésta se presenta como "toda una familia de 'nuevos sistemas”” (32) que están encadenados, creando, de esta suerte, el flujo y continuidad de significantes antes aludidos. Según Benítez Rojo, al tomarse conciencia de este lugar, necesariamente contemplativo, queda de relieve la importancia de la actuación o performance y el ritmo como protagonistas de eso "remoto que se reproduce" (36). Asimismo, esta forma de ver la cultura caribeña coincide con la idea de la metáfora o del modelo, en específico, según Paul Ricœur. Para el antropólogo francés, ambas nociones (metáfora y modelo) son instrumentos de descubrimiento que buscan romper, por medio de su referencialidad ficcional, las interpretaciones inadecuadas de la realidad y, por lo tanto, funcionan para abrir el camino a una nueva y más inquisitiva (re)interpretación y 
(re)descripción (Valdés 643). Por esto la cultura sirve como modelo que entrevé nuevos sistemas, sobre todo a través de la representación y de lo rítmico, puesto que son herramientas que reinterpretan o releen la realidad.

Considerando lo anterior, hay entonces que separarse de sí mismo con tal de captar lo que es imposible en una primera lectura, es decir, desde un adentro. Por lo tanto, en la relectura, en la cierta manera, se consigue un doble reconocimiento. En lo caribeño, esto afirma lo propio y lo ajeno: ambos se conjugan para manifestarse en lo ilimitado, en las tantas posibilidades que generan las culturas e, igual, las metáforas. Concretamente, el autor cubano evoca en su ensayo que, "La cultura es un discurso, un lenguaje, y como tal no tiene principio ni fin y siempre está en transformación, ya que busca constantemente la manera de significar lo que no alcanza a significar” (Benítez Rojo 41).

De ahí que el caos funcione de modo acertado para entender los avatares culturales. La inherente imprecisión de la cultura, sobre todo en el espacio descentrado del Caribe, permite expresar sus formas fluidas. Además, dado a que "el discurso cultural es el que más se resiste al cambio..., [puesto que] está ligado al deseo ancestral de los grupos humanos de diferenciarse lo más posible unos de otros” (Benítez Rojo 41), aporta a comprender con mayor certeza la identidad de la población. La cultura se manifiesta como "Un artefacto sincrético [que] no es una síntesis, sino un significante hecho de diferencias” (41). El sincretismo en el Caribe surge de la interacción y reacción de las distintas culturas, hoy llamadas tradicionales; las de "la Europa preindustrial, en el subsuelo aborigen, en las regiones subsaharianas de África y en ciertas zonas insulares y costeras de Asia meridional” (41). Benítez Rojo, específicamente, "se refiere a un interplay de significantes supersincréticos cuyos centros principales se localizan” en estos espacios (41). 
Para añadir, el ensayo también advierte que lo tradicional se mantiene como parte del fluir caribeño, incluso a pesar de la influencia e interacción con lo ajeno. Lo extranjero provee otra forma de mirar eso tradicional, o si se quiere, sirve para establecer una diferencia sin descomponer o eliminar lo existente. Esto, nuevamente, se denota a través de una relectura de la cultura caribeña. El Caribe, todo lo que contiene y genera, es visto entonces como texto. En el motivo metafórico de este concepto se representa el leer, releer, analizar, transformar, evaluar, reevaluar... lo leído/observado. ${ }^{154}$ En un primer intento, al leer el texto Caribe, no pueden apreciarse las diferencias que simultáneamente conectan y establecen las semejanzas, las cadenas de propósitos o bien de significantes. Así, lo ya indicado surge debido a que, “en el Caribe, lo ‘extranjero' interactúa con lo 'tradicional’ como un rayo de luz con un prisma; esto es, se producen fenómenos de reflexión, refracción y descomposición pero la luz sigue siendo luz” (Benítez Rojo 41). De este modo, la relectura de lo caribeño es necesaria para entender conjuntamente el prisma de su identidad cultural. En particular, al considerar que

...el texto caribeño es excesivo, denso, uncanny, asimétrico, entrópico, hermético, pues, ... abre sus puertas a los grandes órdenes de lectura: una orden secundaria, epistemológica, profana, diurna y referida a Occidente -al mundo de afuera-, donde el texto se desenrosca y se agita como un animal fabuloso para ser objeto de conocimiento y de deseo; otra de orden principal, teleológica, ritual, nocturna y revertida al propio Caribe, donde el texto despliega su monstruosidad bisexual de esfinge hacia el vacío de su imposible origen, y sueña que lo incorpora y que es incorporado por éste. (44; énfasis del autor)

Sin dudas, se trata de un constante movimiento que permite la entrada y salida de la circulación cultural. Va transformándose lo pasado y simultáneamente manteniéndose, sin ser o hacerse una copia de lo anterior. Por llamarlo de algún modo, es un juego de acoplamiento y distención que necesita de ambas dinámicas para Ser. 
En adición, ulteriormente el escritor cubano indica que la realidad caribeña es representada a través de componentes artísticos. Por consiguiente, “...lo que sí es característico de los caribeños es que, en lo fundamental, su experiencia estética ocurre en el marco de rituales y representaciones de carácter colectivo, ahistórico e improvisatorio” (Benítez Rojo 42). De esta manera el texto denomina el espacio del Caribe como uno de catarsis carnavalesca. En otras palabras, es un lugar en donde se producen momentos que tienen “la capacidad de simbolizar actuación ritual” (42). ${ }^{155}$

\section{El espacio geográfico}

La geografía del archipiélago o meta-archipiélago del Caribe interesa como representación de lo impredecible. Lo que Benítez Rojo define como la cultura caribeña surge porque "No hay centros ni bordes, pero hay dinámicas comunes que se expresan de modo más o menos regular dentro del caos y luego, gradualmente, van asimilándose a contextos africanos, europeos, indoamericanos, asiáticos, hasta el punto en que se esfuman” (Benítez Rojo 45). Por consiguiente, incluso a partir de la composición geográfica, sus elementos comienzan a expresarse de modo imperceptible. Tal como las islas se repiten físicamente en el espacio caribeño, también a través de la repetición, de acuerdo al autor, se forma su cultura.

Para ilustrar lo indicado solo basta con comenzar a observar el mapa del Caribe. Mientras se percibe su disposición física, se devela que no es posible describir su espacio enfocándose en solo una isla, ya ésta sea Cuba, Martinique, Curaçao, Puerto Rico, Jamaica o cualquier otra. Es evidente que solo una descripción objetiva y profunda señalaría su totalidad; de otra forma sería una caracterización a medias o, según el autor, se trataría de una primera lectura en la que “el lector se lee a sí mismo” (Benítez-Rojo 32). Así, pretender definir el espacio caribeño únicamente mirando su composición geográfica, como si bastara con tener un atlas

del archipiélago en mano, sería una interpretación meramente superficial. Sin embargo, en 
términos de una primera mirada trasluce que cada isla se diferencia, variando en tamaño, forma y en mucho más. Por supuesto, eventualmente habría que hacer un acercamiento (un zoom, como si fuera un mapa interactivo), para conseguir los detalles de manera efectiva, como se hace con una lectura avanzada, y así poder releer o reexaminar lo ya visto. De este modo, a través de las relecturas se descubren los caminos del caos, sin límites, percibiendo así los tantos errabundos significantes (33).

No obstante, no cabe duda que la cultura antillana se forma 'de cierta manera' como paradigma de su geografía. En específico, se trata de la “cultura del meta-archipiélago: [que] es un caos que retorna, un detour sin propósito, un continuo fluir de paradojas; es una máquina feedback de procesos asimétricos” (Benítez Rojo 30). En otras palabras, es un terreno en el que no pueden advertirse ostensiblemente sus resultados. Por un lado, el hecho de que el archipiélago sea un grupo numeroso de islas que se encuentra abierto a las corrientes y al flujo marítimo, demarca la existencia de sinfín de movimientos. Por eso la cadena de islas propicia los enlaces culturales existentes y sus continuidades. Paradójicamente, también "La metáfora archipielística lleva asociada inevitablemente la idea de frontera. Pero no una frontera cualquiera: es una frontera comunicante, multidireccional y flexible” (Orrego 123), puesto que lo fronterizo es demarcado por el mar. Así las cosas, como el agua es fluida, se crea un espacio abierto y móvil. La composición del Caribe, por ende, advierte la creación de

un concepto territorial como isla y archipiélago [que] adquieren una complejidad tan profunda como inmanejable. [Por esto,] María Dolores González-Ripoll en su artículo "Archipiélago e archipiélagos: haciendo la(s) historias(s) del Caribe”, describe las diversas consideraciones que han existido sobre el Caribe, señalando cómo la definición de archipiélago es quizás una de las más imprecisas. (Orrego 124) 
De ahí que Benítez Rojo se haya valido de una locución como la ‘de cierta manera’ para explicar lo caribeño. Éste, consciente de un punto de partida complejo, fluido e indefinido como lo es la geografía del Caribe, describe la cultura a partir de su espacio como una inevitable reproducción de esas dinámicas. Por esta razón, al nombrar "La cierta manera o [decir] Ser de cierta manera no llega a cristalizar un concepto preciso; es algo ‘oscuro’ y ‘remoto', ... un ritmo que es anterior ... que actúa enigmáticamente” (Díaz Quiñones, “Caribe y exilio...”, 12). En Benítez Rojo, añade Arcadio Díaz Quiñones, la identidad caribeña se sitúa “más allá de las ideas convencionales de nación o de raza” (12). Además, tampoco ésta se encuentra en una de las islas, sino en el conjunto del ‘meta-archipiélago’ que “se inscribe en el espacio, y, por tanto, [aunque] las islas son, a la vez, 'originales' y 'copias': son variaciones históricas de la Plantación y de las culturas criollas. Los procesos son inscritos en cada una de ellas con sus propios y singulares efectos y temporalidades, producidos en momentos históricos distintos. Las islas son simultáneas y no sucesivas” (12). Es decir, el Caribe coexiste 'de cierta manera' en cada una de sus islas sin situarse determinada y únicamente en una de éstas.

El espacio insular caribeño como no-violento: Pedreira y Benítez Rojo

Aunque el espacio antillano se ha caracterizado por sufrir constantes conflictos, la respuesta de sus habitantes ha tendido a ser la de evadir la violencia. Varios académicos han señalado esta particularidad y advierten cómo inclusive se ha considerado como parte de la identidad cultural caribeña. Antonio S. Pedreira, ensayista puertorriqueño, desde la década del treinta del siglo XX, sostuvo en Insularismo (1934) que Puerto Rico es "un pueblo ajeno a la violencia y cortésmente pacífico, como [su] paisaje” (Pedreria 41). ${ }^{156}$ Éste sugiere que la forma física de la isla influye en el carácter social. Por otra parte, según Benítez Rojo, esta cualidad está presente en todo el Caribe, en donde “ocultan la violencia inherente a todo 
origen sociológico” (Benítez Rojo 50). Precisamente, el cubano indica que se trata de un "territorio marginal e iniciático de la ausencia de violencia” (46). En ambos, la disposición del espacio insular y archipielístico moldea las distintas formas del 'Ser’ en el Caribe.

Unas de las primeras razones que el académico puertorriqueño advierte como determinante para la cultura de la isla, son la frontera acuífera y la extensión limitada de tierra. De acuerdo a Pedreira, esto es impedimento para el progreso del pueblo en cuanto a la nación y la cultura. Su afirmación es que es imposible "avanzar hacia el mar para hacer la expansión del territorio” (Pedreira 43). Además, no solo el mar impide el crecimiento del espacio sino también el lugar geográfico que ocupa. Con esto, en su razonamiento abarcan sinnúmero de argumentos, incluso sobre la esfera económica, abordándolos de la siguiente manera:

La posición geográfica de Puerto Rico [y de todo el Caribe] determinó el rumbo de nuestra historia y de nuestro carácter. ... Comercio y estrategia intervienen en el crecimiento de nuestra personalidad colectiva... Para colmo de la desesperación nos cupo la desgracia de caer asilados del mundo... Esto nos privó de la autoridad que dan las grandes masas de pueblos a las demandas del respeto universal. Nuestra patria ha añorado siempre ese bulto de tierra tan necesario para servir de fondo.

En proporción a su tamaño se desarrolla su riqueza, y por lo tanto su cultura. Siendo geográficamente el centro de las dos Américas, su falta de volumen, su carencia de puertos y de comercio en grande la convierten en rincón. Como centro comprimido no servimos más que para la estrategia y para hacer escala; ... y como centro económico la extensión geográfica sólo permite negocios reducidos... (Pedreira 43-4; mi énfasis)

Con esto, de algún modo, en Pedreira hay un regreso al determinismo geográfico del siglo XIX. Por ejemplo, se asemeja a las ideas propuestas del francés Hyppolite Taine sobre cómo el ambiente físico o lo histórico-geográfico media el plano artístico-cultural de un país. A su vez, Taine influye en Sarmiento, específicamente, en Civilización y barbarie (1845). Así, ese determinismo en Pedreira está en las ideas sobre la posición física como estratégica y como posibilitadora de las transacciones comerciales; sin embargo, también está en que como 
su extensión territorial es reducida, igual su capacidad de desarrollo y crecimiento económico.

De este modo, la consciencia colectiva del caribeño, para Pedreira la del puertorriqueño, queda ceñida a su geografía. Más adelante incluso añade que esto es un defecto, que la composición física de las islas restringe y crea una cultura de poca importancia:

Llevamos encima la tara de la dimensión territorial. No somos continentales, ni siquiera antillanos: somos simplemente insulares que es como decir insulados en casa estrecha. Encogidos por la tierra, tiene nuestro gesto ante el mundo las mismas dimensiones que nuestra geografía. ...y estamos habituados a tropezar con un paisaje inmediato que casi tocamos por sus cuatro puntas. (Pedreira 44)

Lo que para Pedreira limita el carácter socio-cultural de los isleños, para Benítez Rojo es lo contrario. Es decir, la geografía como restricción es opuesto a la visión globalizante que propone Benítez Rojo. El escritor cubano indica que la naturaleza abierta del Caribe permite la fluidez de elementos y la creación de dinámicas ilimitadas y que "La insularidad... no ... impele al aislamiento” (Benítez Rojo 45).

En todo caso, considerando la propuesta del cubano, las afirmaciones de Pedreira bien pueden presuponer solo una primera lectura de Puerto Rico y, por consiguiente, de las demás islas caribeñas. La mirada del catedrático puertorriqueño es que, "La tierra, pues, reduce el escenario en que ha de moverse la cultura” (Pedreira 44). No obstante, en la reinterpretación de Benítez Rojo se consigue una mirada más avanzada del Caribe que consiste en que esa composición territorial es lo que precisamente amplía el espacio cultural. Mas a pesar de estas diferencias, ambos intelectuales coinciden en cuanto a la manera de observar las trayectorias históricas y sociales de este espacio. Esto es, Pedreira reconoce, 'de cierta 
manera’, las dinámicas del caos al indicar que, “tal vez [se] trafiquen contradicciones internas y visibles repeticiones que nacen de la misma vitalidad del problema” que aborda en su libro. Sucede así que el autor puertorriqueño ilustra una idiosincrasia en común (un mito de época); el espacio insular está plagado de "elementos dispersos que laten en el fondo de nuestra cultura, y ... los puntos culminantes de nuestra psicología colectiva” (Pedreira 21).

Por supuesto, aquí las repeticiones y los elementos dispersos que menciona el escritor puertorriqueño, en particular, es una referencia centrada en la cultura de su isla. Sin embargo, no debe descartarse que éste puede relacionarse con el análisis que hace Benítez Rojo. El hecho que, desde la primera página de Insularismo, se aclare la naturaleza contradictoria, repetitiva y colectiva de los temas a abordar en su texto, corrobora esa simultaneidad caribeña que el cubano distingue. Lo que Pedreira expone es ciertamente una particular diferencia en la repetición existente en cada una de las islas. Así, se desencadenan las formas culturales más impredecibles y diversas (Benítez Rojo 50). Por ejemplo, en una sola isla un elemento cultural podría aparentar no estar presente (al menos en términos de esa primera lectura), mas por otra parte, en otra isla, ese mismo componente se encuentra o denota "bullente y constante”. Dos casos evidentes son: “el grado de africanización de cada cultura local [que] varí[a] de isla a isla, y que el impacto aculturador de la plantación se manifiest[a] asimétricamente” (Benítez-Rojo 50).

\section{La estética-poética de Benítez-Rojo}

La crítica (Díaz Quiñones) ha señalado que La isla que se repite puede verse como parte de la poética de su autor y que la denotación que hace éste de la teoría del caos funciona dentro de dicha estética. La singularidad del texto, entre otras cosas, es su manera de definir lo caribeño a partir de expresiones difusas y aun encontrar planteamientos que coinciden con las perspectivas posmodernas, sin anclarse a éstas. Del mismo modo, la teoría que propone el 
escritor, en base a las dinámicas de los sistemas caóticos, en diálogo con las humanidades, alude a "un espacio que solo puede ser intuido a través de lo poético, puesto que siempre presenta una zona de caos” (Benítez Rojo 37). Benítez Rojo observa en la actuación o en el performance de los habitantes caribeños, en su memoria o en el baile, lo poético; identifica así un polirritmo (ritmos iniciales desplazados por otros ritmos), tal como Benoît Mandelbrot concibe sus modelos matemáticos. En específico, constata autorreferencialidades que se repiten “a sí mismas en diferentes magnitudes” (404). ${ }^{157}$ Por esto, las referencias y referencialidades del Caribe son hechas por Benítez-Rojo a partir de lo estético y desde "los sentidos, de los sentimientos y los presentimientos” (Benítez Rojo 29). Esto es ya que lo artístico permite y crea distintas profundidades que funcionan para representar las repeticiones de la percepción y comprensión de la realidad .

Por una parte, el ensayo alude a varias formas en las que el arte caribeño sirve como reflejo de la cultura a través de las dinámicas del caos. Esto, debido a que existen regularidades comunes en estado de fuga. Un ejemplo se da en la literatura multilingüística del Caribe. Primeramente, de acuerdo al académico, hay "un desplazamiento metonímico hacia las formas escénicas, rituales y mitológicas, esto es,... [produce] bifurcaciones y paradojas” (Benítez-Rojo 46). Además, existen también varias fuentes rítmicas que se perciben en las relecturas y que crean un juego variado de cadencias (46). De la misma manera en que la literatura ilustra estas características, las expresiones múltiples y populares caribeñas, como el mito, la música, la danza, el canto, el teatro, son "modelos en busca de rutas que condu[cen], al menos simbólicamente, a un punto extra-textual de ausencia de violencia sociológica y de reconstitución síquica del Ser”. Lo que resulta en "un texto que habla de una coexistencia crítica de ritmos, un conjunto polirrítmico cuyo ritmo binario central es des-centrado” (49). 
Por otro lado, lo estético linda con otras esferas que bullen en el movimiento que se produce en el caos caribeño. Por supuesto, como se ha ido viendo, el escrito de Benítez Rojo no se detiene en un sitio fijo, sino que involucra "not a fixed state of affairs, but a flow or oscillation, a constant movement towards the liberty of an 'over there', a constant motion between the multiple centres within the Caribbean cultures and within the individual” (Hoeg 72). Considerándose esto, en $L a$ isla que se repite la estética que se presupone en la actuación o el performance de la cultura caribeña se encuentra, no "solo como representación escénica, si no también [como] ejecución de un ritual, es decir, esa ‘cierta manera’... [en la que] se expresa el légamo mítico, mágico” (Benítez Rojo 31). Aquí, cabe reconocer que la subjetividad y los posicionamientos múltiples que se distienden de lo ritual, lo mítico o lo mágico, juegan un papel preponderante como parte de los componentes culturales, de la historia caribeña y de lo que resulta de sus dinámicas. Incluso, estos dispositivos se encuentran presentes antes y después de las voliciones que forman las repeticiones culturales en el Caribe.

\section{La brega: metáfora de la estrategia y la negociación en la cultura del Caribe}

El ensayo “De cómo y cuándo bregar” de Arcadio Díaz Quiñones es el producto de una serie de artículos publicados en la revista puertorriqueña Palique en 1999. Luego, en el 2000, el escritor compila este y otros escritos en el texto El arte de bregar. Este análisis se enfoca en el primer ensayo del libro, en el que se estudia el verbo 'bregar' como indicador de una acción estratégica y de negociación. La presente investigación advierte cómo dicho concepto funciona como metáfora de los dobleces o desdoblamientos de la cultura puertorriqueña y, por extensión, la de todo el Caribe. Díaz Quiñones afirma que la brega

juega el rol de mediar la realidad y que puede denominarse como un arte de la fuga. Para el académico, 'bregar' es darse permiso al fracaso, dejar abierta la posibilidad por si las cosas 
no suscitaran como se desea. No obstante, simultáneamente, el término implica un triunfo, sea éste cercano o remoto. Esa doble contingencia se determina a través del tono que le adjudique el hablante y del contexto en el que se utilice la palabra. El habla se presenta entonces como herramienta que moldea el vocablo y sus posibles connotaciones.

De esta suerte, la multiplicidad de opciones que surgen a partir del uso de esta expresión es de tal envergadura que suscita un tropo cultural. Esto es, el vocablo provee maleabilidad y permite optar entre la gran variedad de rasgos o elementos que conforman la cultura. Aquí, el bregar interesa por su flexibilidad. En especial, el concepto reconoce un intercambio de significaciones de acuerdo a las circunstancias en las que se utilice. Así, éste puede entenderse como más de una cosa a la vez. Por eso en contextos determinados adquiere el sentido que insinúa el tono y los gestos empleados al pronunciarse. Sin embargo, bregar tiene una definición base que siempre se mantiene a pesar de incluso articularse con una intención de apariencia contraria.

Por lo tanto, en la pluralidad de significados de la brega está presente una función metafórica. Cada una de sus posibles dilucidaciones tilda el carácter cultural colectivo de los habitantes de las islas caribeñas. De ahí que el término aporte a ilustrar una cultura colectiva en Puerto Rico y el resto del Caribe (en algunas islas más que en otras). Por ejemplo, en el caso de los cubanos el uso del verbo resolver (o inventar) es similar al de bregar. Díaz Quiñones advierte que se trata de

[un] actuar sin romper las reglas del juego, [un] esquivar los golpes que propina la vida cotidiana y, en algunos casos, extraer con astucia las posibilidades favorables de los limitados espacios disponibles. [Podría ser] una maniobra defensiva frente a las 'retóricas de la intransigencia'. ... Bregar es una práctica y también un trabajo retórico, un trabajo con el lenguaje por parte de quienes hace tiempo dejaron de creer en la bondad de los poderosos. (Díaz Quiñones 47-8) 
No cabe duda que, en ambos casos, se refiere a una posición ideológica. En particular, se advierte un momento de tomar acción; una situación en la que se está en la disyuntiva, como popularmente se dice, de ‘tomar el toro por los cuernos’. Utilizo aquí esta expresión popular como una manera de entrar en el mismo juego de palabras que ilustran el quehacer cotidiano. Al igual que el puertorriqueño brega, el cubano "resuelve todo lo que se pueda, donde se pueda y como se pueda” (Dihigo). ${ }^{158}$ Aunque los contextos políticos y económicos en ambas islas (y en todo el Caribe) se diferencian de forma notable, la cultura caribeña mantiene lazos de isla en isla que son imposible desatar. Así, cuando se hace uso de estos vocablos, existe “un mensaje subliminar [que incluso a veces torna a ser] de carácter delictivo, porque cuando decimos resolví tal cosa [o bregué o bregó ante algo], siempre queda en el aire la interrogante” de cómo se resolvió o bregó (Dihigo). Estas expresiones puertorriqueña y cubana permiten actuar o moverse frente a varias posibilidades dentro de distintos contextos.

Por esta razón Díaz Quiñones aborda en su ensayo un sinnúmero de posibles connotaciones que tiene el arte de bregar. Los diversos significados son ejemplos de la versatilidad de la palabra y, por consiguiente, de su metáfora. Se trata de "otro orden de saber,... [de lo] precario, cambiante o violento”. Al mismo tiempo,

Es una forma de estar y no estar, un tipo no preciso de lucha, una negociación entre la ausencia y la presencia. ... [es] una figura... [de] ritmo propio. ... [que sirve] para reconocer y reconocerse, y para diferenciar un valor distintivo de la subjetividad colectiva, así como [de] los esplendores y las miserias que la movilizan. (Díaz-Quiñones 20-1)

Por consiguiente, ilustra cierto conformismo, mas disfrazado, puesto que presenta una disyuntiva entre el sujeto caribeño y el mundo de afuera. Se traduce entonces como un particular modo del pensar antillano. 
Entre los tantos posibles alcances que adquiere el término, igualmente se presenta como una forma de sabiduría o una destreza para resolver alguna situación en específico. De manera semejante, el concepto alcanza un carácter de alivio, pacto o salida a una crisis. Por ejemplo, en una conversación funciona como "punto de viraje en el diálogo; [devela así lo posible y lo deseable] hasta encontrar un modo de alcanzar el difícil equilibrio entre elementos potencialmente conflictivos, ... de armonizar necesidades e intereses” (21-2). Inclusive, Díaz-Quiñones señala que, de acuerdo a lo propuesto por Kenneth Burke, bregar funciona como una metáfora estratégica que ulteriormente muestra una acción que propone crear movimiento/respuesta en quien(es) y para quien(es) se brega (22).

Ese movimiento en el que el interlocutor recibe un mensaje y, luego, modifica su situación, advierte un sentido de lucha. Sin embargo, el bregar caribeño no supone un ataque frontal sino que, al contrario, se aleja de la trasgresión directa sin dejar de establecer una pugna con algo o alguien, con o contra otro(s): “Supone la presencia real o imaginaria de otros, y la posibilidad de tomar la palabra, un combate verbal con sucesión de acercamientos y distanciamientos. Exige el diálogo, la seducción del lenguaje, o saber callarse a tiempo, y, a menudo, deslizarse hacia la ficción o el engaño” (Díaz-Quiñones 24). Así, al bregar se entra en una dimensión artificiosa que permite, desde un mismo lugar, una apertura a diversos modos de ser, de expresarse, representarse o proyectarse. Es un mecanismo para manejar "las múltiples estrategias teatrales que se dan en la vida cotidiana” (27). Se trata entonces de una fórmula del habla, una herramienta que "despliega su significación en una multiplicidad de niveles en el fluir del lenguaje” (41).

Por otro lado, cuando se brega hay un colocarse detrás de un antifaz. Se permite así exigir o proporcionar movimientos estratégicos para tomar otra acción. Específicamente, a través del discurso, se inserta el vocablo bregar develándose así una actitud o incluso una forma de 
vida. Cabe indicar que no se trata de un disfraz semejante a la máscara racial, la del blanco, aludida por el estudioso Franz Fanon. Es cierto que bregar también puede implicar una mimesis o imitación de la cultura de otro, no obstante, no siempre es de esta manera. Recordemos que, en Fanon, hay una aceptación cultural de ese Otro (por eso se imita). Sin embargo, en la brega se quiere persuadir a ese otro. Esto es posible al punto que es a través del engaño (si fuese necesario) que se busca cambiar el enfoque del Otro para que éste admire o celebre a quien brega. Incluso, también sugiere un rechazo hacia quienes no actúan bregando.

Ahora bien, como ya se ha visto, no siempre el bregar toma la forma gramatical del verbo, es decir, de la acción. En tanto parte del lenguaje, si se cambia la grafía se transforma el enfoque según el propósito del hablante al usar la palabra. Con esto, el concepto se aleja del foco de la acción de un sujeto. Así, Díaz Quiñones afirma que “La brega no siempre es un acto. Es también algo distante y que distancia: el pensamiento y la conciencia misma del bregar” (27). Por consiguiente, el sujeto que brega malea su quehacer según las disposiciones lingüísticas que se consideren. De ahí que "Los giros y los tonos de la brega pertenecen a la lengua hablada y a su escurridiza historia” (Díaz Quiñones 27); que en el Caribe es parte inherente de la cultura. Esto, en el espacio antillano en general, se da en el idioma hablado que está muy marcado por "la larga experiencia colonial, las heterogeneidades internas, y las migraciones masivas. [Aún más,] Son parte central de una tradición” (27). ${ }^{159}$

Así las cosas, el académico afirma que cualquiera de las manifestaciones que supone la brega o el bregar son representaciones de la cultura del puertorriqueño. La brega simboliza “una sociedad de grandes penurias y desplazamientos... de apariencias y simulaciones” (Díaz-Quiñones 27-8). Esto excede lo puertorriqueño, puesto que es también la realidad de 
toda la sociedad caribeña. Aún más, según Quintero Rivera sugiere, es un “producto del arte de la fuga, étnica y culturalmente muy mezclad[a], y relativamente aislad[a]” que desempeña “subterráneas formas de lucha contra poderes internos y externos” (Díaz Quiñones 28). Es cierto entonces que en el Caribe, tanto en la cultura como con el vocablo bregar, se muestran cadenas de significaciones que surgen de las variadas contiendas en sus respectivas sociedades.

\section{Regreso al 'Ser’ caribeño}

Sinnúmero de académicos advierten cuan arduo ha sido describir la cultura plural del Caribe. Precisamente, de igual modo, la crítica apunta que el Ser caribeño presenta dificultades culturales y que éstas son parte de su identidad. En particular, Díaz Quiñones asevera que "Los usos puertorriqueños del bregar encierran cientos de historias en torno a las dificultades del ser” (Díaz-Quiñones 38). Estas ‘dificultades del ser’ son una manera de recalcar las multiplicidades culturales caribeñas. Se trata de la presentación de un "sujeto [que] se afirma ocultándose parcialmente. Se anticipa, con ese desdoblamiento, el carácter que algunos han visto como constitutivamente indeciso, o doble” (41).

Por cierto, a partir de los usos de la brega se identifican dinámicas del sujeto caribeño. Indudablemente, la brega es un relato "muy caribeño, de identidades obligatorias y elegidas que ejemplifican la necesidad de adaptarse a las circunstancias, de construirse como sujeto en espacios sociales restringidos” (Díaz Quiñones 44). Así, de acuerdo a lo expuesto por el ensayista, otras de las 'dificultades del Ser' es la maleabilidad ante variadas situaciones y la capacidad de auto(re)formarse. Para lograrlo, se toma la determinación, consciente o inconsciente, de posibilitar dichos cambios. Por ende, "Es un sistema de decisiones y de indecisiones - un complejo de definiciones, interpretaciones y prohibiciones” (47). En ese espacio de resolución, el bregar proporciona movimiento y liberación. De esta forma, la 
brega es un reflejo del Ser caribeño que se desdobla y se multiplica: "Bregar es una manera de tomar la palabra, y un modo de actuar que a menudo lleva a la duplicación y a las duplicidades” propias de la cultura caribeña (Díaz Quiñones 49).

De hecho, el texto hace referencia a las posibilidades que suscitan en la cultura a través de la brega. El análisis del académico puertorriqueño se basa específicamente en descripciones que definen el carácter de los habitantes de su isla. Sin embargo, como se ha indicado, se trata de las formas del 'Ser' caribeño en general, ya que “La cultura también viaja, y es desplegada en los nuevos espacios, aunque con temporalidades heterogéneas” (DíazQuiñones 51). Por ejemplo, puede decirse que en cualquier cultura se brega para exponer y validar un punto de vista. De igual manera, en esta investigación se brega para señalar puntos de encuentros culturales, para equiparar o armonizar las formas de 'Ser' que, en las Antillas, comparten historias semejantes y contextos paralelos como los estragos del sistema colonial y la vida alrededor de la Plantación. Por otra parte, considerando que la brega es vista como una forma de manipulación, entonces supone un apropiarse de otras culturas, situarse entre éstas y participar así de ambas (o de todas) al mismo tiempo. De ahí que se vea como una oportunidad para "armonizar productivamente lo local y lo universal" (58), lo puertorriqueño y lo caribeño, en una o varias islas del archipiélago. Así, se ilustra que, semejante al concepto aquí analizado, “Las culturas son objetos que se manipulan para todos lados” (58).

De esta suerte, para definir el 'Ser' caribeño no conviene proponer un modo fijo (inclusive, esto sería ilusorio). Por consiguiente, la mirada al espacio caribeño no puede reducirse a una cultura consolidada, a una idea o verdad establecida. Al contrario, hay que conciliar lo múltiple, analizándolo en un ir y venir o, por nombrarlo de alguna forma, en círculos de negociación (Díaz-Quiñones 67). Bregar "Es más bien un sistema de decisiones 
y de indecisiones” (61). Por eso la palabra es tanto pragmática como simultáneamente ilógica o contradictoria, ya que "Es una forma épica de estar y no estar que permite abrirse paso con cautela” (70). Es además un acomodarse, "un ejercicio trabajoso" que tiene "el propósito de reconocerse y de mostrar las conexiones entre lo disperso y lo diverso” (80). En ese (re)conocerse y (re)conectarse con los diferentes componentes de la cultura, no solo se afirma la posibilidad de identificar lo caribeño con el arte de bregar, sino también se asemejan las formas de 'Ser’ de los habitantes de cada una de las islas.

\section{El ensayo y el bregar}

Como la brega y el bregar resultan ser de usos y significados múltiples y manipulables, de modo similar el término opera como metáfora de la cultura del Caribe. Además, que el análisis de esta noción se haga a través de la forma literaria del ensayo permite ampliar las posibilidades de este tropo cultural. En primer lugar porque el ensayo "se desembaraza de la idea tradicional de verdad” (Adorno 20). Más aún, en un segundo plano, la concepción de la verdad igualmente puede denotarse como metafórica. De acuerdo a Ricœur, la verdad metafórica, en un sentido amplio, "se refiere al empleo de predicados o de propiedades a algo por una especie de transferencia” (Ricoeur 274). ${ }^{160}$ Por consiguiente, al transferir la función verbal de bregar, inicialmente como núcleo del predicado, a otro sentido u otra cosa, su realidad contextual también se transforma. Es decir, el fin del término dentro de la forma ensayística es transferir las nociones de la realidad y malearlas como elementos metafóricos, en este caso, de la cultura.

En específico, el bregar o la brega se traslada del espacio hablado, popular y práctico, a un plano teórico. Díaz Quiñones hace objeto de estudio el término bregar analizando las distintas afirmaciones de dicho concepto. Esto es, "El ensayo denuncia sin palabras [o sea a través de su forma] la ilusión de que el pensamiento puede escapar de lo que es thesei, 
cultura, a lo que es physei, por naturaleza” (Adorno 21). No obstante, al añadir el elemento metafórico, bien puede ser una y otra: cultura y naturaleza. Por esto, bregar "Funciona como un mecanismo de desplazamiento que permite manejar contradicciones sin apelar a la violencia, colocar la acción en una línea lejana y prometedora, aun cuando ello genere identidades enigmáticas” (Díaz Quiñones 61-2). Precisamente, esa identidad enigmática es una manera más de nombrar lo caribeño. Por dar algunos ejemplos, en lo enigmático o lo misterioso se alude a lo obscuro, una imagen que advierte Glissant; por otra parte, también hace referencia a lo inexplicable, tal como propone Benítez Rojo.

Al finalizar el ensayo, Díaz Quiñones abre la posibilidad de crear nuevas propuestas y hábitos para que la brega sea colectiva. Entonces, esta palabra implica en sí una consciencia de lucha que debe aspirar a la existencia de un más allá que incluso esté presente después del bregar. Tal proposición reconoce que

bregar es un ensayo, un esfuerzo por obtener la adhesión de otra persona. ... [entonces] consciente de su propia vulnerabilidad. ... La brega, de hecho, guarda semejanza con el ensayo literario, género que se aleja deliberadamente de la ilusión de totalidad, y permite proceder metódicamente sin método, ... En el campo de batalla del lenguaje, es el arte del rodeo, el dominio de las reglas de la retórica. (Díaz Quiñones 81)

Así, en tanto concepto que representa la forma cultural puertorriqueña o caribeña, la brega se asemeja a la forma del ensayo literario. De esta manera, en ambos (el bregar o el ensayo) se media para lograr un propósito en específico, ya sea afirmarse o negarse, sobre todo cuando se refiere a una colectividad cultural. Entrambos, "En situaciones polarizadas, y mediante eufemismos y perífrasis, permite[n] buscar un punto de fuga para fundar nuevos lugares. En otras, hay espacio suficiente para negarse al juego” (Díaz Quiñones 82). Por lo tanto, esta 
metáfora devela una memoria cultural y social, incluyendo todos sus aspectos en una especie de juego simultáneo entre la afirmación y la negación. Por decirlo de algún modo, es una herramienta que deja abierto el camino para reconocer una identidad que, como el ensayo, “no obedece la regla del juego... no apunta a una estructura cerrada, deductiva o inductiva” (Adorno 19). Así, en lo caribeño "pueden verse aspectos contradictorios y mezclados de la cultura, sus paranoias y sus utopías...” (Díaz-Quiñones 83). En otras palabras, la brega, así como la cultura del Caribe, es “una especie de salvoconducto” (Díaz Quiñones 83).

\section{Desorden y libertad: lo femenino como apertura}

El lector ávido ya habrá notado que esta presentación de modelos epistemológicos de la cultura caribeña carece de un énfasis en las mujeres ensayistas. Esto es reflejo de la desproporción que existe entre las producciones literarias masculinas y femeninas en el Caribe. Maryse Condé denuncia esta particularidad en su ensayo, “Order, Disorder, Freedom, and the West Indian Writer” (2000). La novelista y académica guadalupeña, además de trazar una especie de historiografía literaria del Caribe francés, y de cuestionarla, plantea que la literatura femenina antillana se caracteriza por romper las pautas y órdenes implantados por los hombres. Esta investigación propone que Condé esboza un nuevo modelo epistémico de la cultura caribeña.

En primer lugar, la escritora toma como punto de partida la historia de la literatura caribeña y, luego, introduce la imagen metafórica del desorden. Su idea puntúa que el desorden es representado a través de la escritura de las mujeres. Por lo tanto, de acuerdo al pensamiento condeciano, las féminas son las que subvierten el orden establecido. Este orden, aquí masculino, se señala como desprovisto de una mirada amplia y acertada de la realidad. Aún así, los textos de los hombres en la cultura del Caribe han sido inscritos por la mayoría como modelos a seguir. Sin embargo, Condé asegura que estos prototipos imponen un 
esquema que limita la libertad y, en específico, la imaginación. Por ende, la literatura femenil posibilita un espacio que brinda mayor inventiva. De este modo el desorden funciona como símbolo de apertura de los parámetros de la literatura del Caribe, generándose una liberación tanto literaria como cultural.

La guadalupeña advierte que en la literatura antillana hay una necesidad de crecimiento, de imaginación. Por una parte, ésta considera algunas ideas del escritor martiniqués Edouard Glissant, particularmente, las referidas en los libros Discours Antillais y La poétique de la relation. ${ }^{161}$ Por otro lado, Condé también critica lo que establecen los académicos Patrick Chamoiseau, Rafael Confïant y Jean Bernabé en el ensayo “Éloge de la creolité”. En específico, la autora reprocha las pautas y restricciones que estos autores imponen, puesto que, como tal, no dan cabida a ampliar la creatividad. Ésta además recalca que en los estudios de los escritores mencionados se evidencia la falta de las figuras femeninas en las letras del Caribe. Por consiguiente, la académica resuelve enumerar un grupo de autoras (muchas reconocidas), insertándolas en la tradición literaria. Se demuestran así las capacidades creativas de las mujeres y el lugar de importancia que ocupan.

De esta manera, la ensayista asegura que tal como está compuesto el archipiélago caribeño, así deben ser los parámetros de su cultura. Es decir, son espacios abiertos y de constante cambio:

West Indians should be as changing and evolving as the islands themselves. Above all, creativity is a complex process which obeys no rules. A writer confined to a small and isolated village of the West Indies is free to dream of 'Another Land' and make of it the subject of his/her fiction. Creative imagination goes beyond the limits of reality and soars to areas of its own choice. (Condé 160) 
Por esto mismo la creatividad no puede ceñirse a reglas ni a seguir un orden. Para la escritora, en cuanto a lo creativo, las ideas que exigen una disposición determinada son ilógicas e inválidas. Incluso, Condé utiliza a Glissant para reafirmar su punto de vista: el Mar Caribe, “opens onto the world and its varied energetic influences” (Condé 160). Así, se propone que los caribeños deben crear sin limitarse, de acuerdo a las vigorosas dinámicas del fluir archipielístico. ${ }^{162}$

Al abrirse la esfera cultural para que exista mayor creatividad, a través de la trasgresión del orden, se descubren otras maneras de observar la sociedad. Por esto, Condé asegura que "Disorder meat the power to create new objects and to modify the existing ones. In a Word, disorder meant creativity” (160). Ahora, la escritura femenina bordea la realidad de modo más consciente y desde otras perspectivas. Por ejemplo, "Whenever women speak out, [demonstrate the topics of] the disease, shock, or disturb”. En adición, “Their writings imply that before thinking of a political revolution, West Indian society needs a psychological one” (161). Así, la guadalupeña afirma que las escritoras subvierten las ideas de los hombres, puesto que sus primordiales preocupaciones no coinciden con las del ámbito político. De ahí que, "What they [, women,] hope for and desire conflicts with men's ambitions and dreams" (161). En otras palabras, las mujeres cuestionan las preocupaciones sociales de los hombres.

De acuerdo a lo indicado, Condé señala que al enfrentar la verdad se amplía lo cultural. Con un orden restrictivo, se ignoran algunas de las partes que conforman el Ser caribeño y, por lo tanto, no puede expresarse de modo fehaciente su cultura. Los escritos masculinos, al relegar y limitar ciertos elementos que configuran lo caribeño, evidencian la falta de mayor consciencia sobre la "realidad”. Incluso, tal como lo expone George Lamming en su libro The pleasure of Exile, la inconsciencia es una forma de esclavitud, así que, "Awareness is the minimum condition for attaining freedom” (12). Si el orden que se establece en la literatura 
caribeña no fragua una apertura hacia múltiples temas, como proponen los textos femeninos, se imposibilita entonces una liberación cultural.

Indudablemente, las escritoras ponen en tela de juicio varios tópicos que han sido parte de la historia antillana. Primordialmente, en los procesos de representación y definición cultural, "la obra de las artistas caribeñas aparece como una propuesta original que promueve otras maneras de entender el pasado y la historia” (Garrido-Castellano 135). Uno de los ejemplos más claros es el constante acercamiento de la escritura masculina al tema racial. Las féminas sugieren un cuestionamiento del por qué la literatura caribeña discute el tema del racismo en el resto del mundo, es decir, fuera del espacio antillano, si todavía sigue siendo una polémica que se entraña en las islas del Caribe y, como tal, habría que discutirlo primero dentro del contexto antillano (lo local). Por esto, Condé asegura que el miedo del hombre caribeño es enfrentar dicho contexto: "West Indian society hates... facing the reality of color prejudice which reminds it of the days of slavery, of the time when to be black was a curse and to possess a fair skin was regarded as a blessing” (Condé 162). De forma contraria a la escritura masculina, "Mental breakdown, madness, and eventually suicide, are common themes among women writers” (162). Por ende, los argumentos en los textos femeniles representan un enfrentamiento de la "realidad" social percibida desde la perspectiva masculina en el Caribe.

Otro tema que afronta el escenario caribeño en la literatura femenina es el de la sexualidad. En los textos masculinos, cuando se alude a lo erótico, se hace en referencia a los hombres, excluyendo así a las féminas. Por esto, al expresarse la sexualidad femenina en las escrituras de las mujeres, el resultado es la trasgresión. La sexualidad de la mujer funciona como "the most striking transgressions of the order imposed by the male writers [, these] are related to the image of men and to the image of Africa” (Condé 163). Esta es una de las 
razones por las que el orden establecido como modelo literario en el Caribe mantiene a las escritoras al margen. Particularmente, cuestionan las imágenes y temáticas que han servido como patrón a seguir. En esa imposición, lo masculino restringe el papel de las mujeres en la sociedad y, en particular, como artistas y escritoras.

Lo mismo sucede con la creatividad y libertad literaria. Condé asegura que no hay nada más fuerte para el hombre negro caribeño que tener que aceptar la trasgresión femenina. Esto es, antes que nada, ya que la escritura masculina en el Caribe busca equipararse con los modelos europeos. Así, se pone a África como contrapartida de la metrópolis. Por consiguiente, los textos femeninos desafían las ideas tradicionales de África, viéndolas como pretexto que evita observar otra realidad caribeña: “Those who want to veil their faces before the harsh realities of Africa cannot accept our truth” (Condé 164). Ahora, esta inaceptación de la verdad recrea las imposiciones del pasado colonial. Se trata de una especie de complejo de inferioridad que está presente en la cultura antillana desde la colonización (164).

Retomando lo antes indicado, Condé afirma que la creatividad es libertad. Que la imaginación, además de funcionar estéticamente, retrata la realidad. Por otra parte, la inventiva, en este caso literaria, posibilita un futuro. El ensayo condeciano propone que no debe seguirse un precepto, más bien, hay que escapar de lo estable y lo fijo, puesto que siempre el ser humano necesita encontrar y reinventar lo establecido. Esto supone la contravención del orden (Condé 164). Por esto, la autora pone la esperanza no solo en las mujeres sino también en la mentalidad de la juventud. Por supuesto, de este modo se daría una apertura de lo caribeño hacia el resto del mundo, en un plano global, es decir, más allá de lo local (165). La escritura de la mujer quebranta la determinada 'dicotomía’ o separación social entre los géneros, tanto en la literatura como en la sociedad y su cultura. En fin, el pensamiento de la autora pone de relieve que la mujer debe ser libre para que su cultura lo 
sea y que, en el futuro, pueda existir mayor libertad, continuidad y creatividad para retratar fidedignamente la realidad social del Caribe. 


\section{Conclusión: exégesis de lo caribeño}

El análisis de los ensayos de los escritores caribeños del siglo XX ha puesto de relieve un desglose de modelos epistemológicos que establecen vías de unidad cultural que configuran la identidad pan-caribeña. Estos modelos funcionan como metáforas o, lo que es lo mismo, como figuras retóricas que trasladan el sentido de una interpretación literaria para la comprensión de lo 'real' cultural. En especial esto se manifiesta precisamente dada la incierta construcción discursiva que caracteriza el espacio del Caribe (Zavala). De ahí que la cultura vista como metáfora consienta un razonamiento que representa simbólicamente la 'realidad'.

Siguiendo la misma línea de pensamiento, los autores han destacado que los modelos culturales de lo caribeño no pueden ser únicos y exhaustivos si se quiere expresar congruentemente las distinciones del archipiélago, su fragmentación, su diversidad racial y lingüística y su segregada historia colonial. El estudio de las epistemologías culturales del Caribe logra una crítica que redefine ciertos aspectos que antes habían determinado una visión parcial del conjunto caribeño. A partir de la (re)delimitación de los componentes que forman cada una de las identidades regionales/particulares/locales de las sociedades en las islas, se consigue examinar críticamente las relaciones (semejantes y contradictorias) entre dichos elementos, los habitantes, sus tradiciones y modos diarios de vida. Considerando con esto además que todos estos dispositivos, históricamente, son resultado directo o indirecto del discurso colonial de la metrópolis.

En la ensayística caribeña lo racial remite a una experiencia distintiva en cada uno de sus territorios. Por supuesto, el grado en el que se acentúan las dinámicas raciales y sus implicaciones se denota según las políticas de las diferentes potencias europeas que dominaban en las colonias de las Antillas. Por eso la influencia de Césaire en la literatura del 
Caribe es innegable. La propuesta del concepto de négritude deshace lúcidamente los paradigmas socio-raciales establecidos en las colonias y, como tal, subsecuentemente incluso, se adaptan a distintas regiones en un contexto global. Césaire maneja la teoría marxista (europea) sobre las relaciones de poder para mostrar de modo congruente que el elemento racial funciona como tropo de esas dinámicas. Esto último posibilita el término césairiano como figura literaria ya que propicia una serie de análisis que desarticulan distintos arquetipos (sociales, económicos, raciales, etc.), de acuerdo a los diferentes contextos. Esa torsión traspone las particulares representaciones así como las subjetividades de cada autor/lector.

Concretamente, la metáfora dilucida que la liberación de la división racial y social significaría acceder libremente al 'Yo' (sujeto caribeño). Por lo tanto el prototipo metafórico de la négritude viabiliza la apertura de las relaciones individuales y colectivas. Por eso el ensayista detrae las ideas de la asimilación pues éstas desdibujan las diferencias propias del ser humano, limitando así su libertad. Bien puede afirmarse que se trata de una ideología utópica del académico, mas es así ya que reluce su intención de marcar equidad en la diferencia. No sorprende entonces que el martiniqués reafirme la distinción racial antillana para comprenderla a través de la relación existente con la cultura africana.

Reconocer la identidad caribeña de acuerdo a la relación entre lo local/interno y lo extralocal/externo es otra dilucidación presente en los modelos cognoscitivos estudiados. Por ejemplo, de la misma manera en la que Césaire hace hincapié en esta correspondencia, igualmente Glissant señala la importancia de la lengua créole vista como representación cultural del espacio antillano a raíz de demarcar su relación con la lengua de la metrópolis. El énfasis en esas dinámicas e interacciones está tanto en Ortiz, que relaciona las mercancías de producción del sistema de la plantación con las disposiciones sociales dentro del mismo 
sistema, en Castro y en Lamming que reconocen una afinidad de los eventos pasados con el presente y el futuro, y en Brathwaite y Jimenés-Grullón que se ve cómo la integración social crea desintegración cultural a partir de la vinculación que surge del desenvolvimiento de las clases sociales dentro de las respectivas estructuras de poder. En este sentido, las proposiciones de Benítez Rojo, Díaz Quiñones y Condé también siguen la idea de (re)definirse según los enlaces que se establecen entre los múltiples elementos que conforman la cultura dentro de los parámetros que la historia colonial ha marcado. Así, cada modelo cultural se origina conforme al establecimiento de nexos tanto particulares como plurales.

Manteniendo una estrecha filiación con lo racial como modo de comprender la cultura en el Caribe, Ortiz configura la identidad cubano-caribeña. La creación del neologismo orticiano representa una (re)formulación de los enlaces entre las tradiciones originarias de los aborígenes y la eventual dominación colonial europea (la entrada de los europeos y los africanos) dentro del sistema de la Plantación. La transculturación es además una figura simbólico-discursiva que representa lo racial rítmicamente a través de simbologías que ilustran los movimientos e interacciones surgidos a lo largo de la historia. De ahí la mirada a la coexistencia de formas heterogéneas, en particular, las diferencias culturales de los distintos grupos raciales. Asimismo el intercambio simbólico de la evolución histórica de los materiales económicos concertados en Cuba (tabaco y azúcar), sus usos, sus técnicas y sus consecuencias, representan los resultados del coloniaje y, con esto, las transacciones de la cultura.

Los ensayos caribeños se caracterizan además porque se complementan diacrónicamente. En otras palabras, existe una interdependencia entre la obra ensayística del siglo XX que funciona como reflejo de las complejas relaciones de poder que se dan en el Caribe (Benítez Rojo 204). La dinámica que denomina Benítez Rojo es una de fuga. Es decir, no se trata de 
ninguna unidad por separado (un solo ensayo o concepto) sino que el conjunto ensayístico forma un complejo armónico que arbitrariamente, en palabras del escritor cubano, se despliegan, se oponen, se alían, se persiguen y yuxtaponen (205). Consecuentemente, adoptando una forma contrapuntística los ensayos dilucidan modelos de las varias representaciones de la cultura. Se establece entonces en el ensayo caribeño un patrón de fuga (Benítez-Rojo) o de reproducciones de la cultura, de sus mutuas y constantes interrelaciones. Cabe señalar que Cornejo Polar llama estas dinámicas simultáneas, correlatos dialécticos. Se trata de una concordancia entre las coacciones del colonialismo vivido en el Caribe y las distintas maneras que luego se (re)producen.

Coinciden además en la producción ensayística posturas de tomas de consciencia del poder colonial/dominante y desde un punto de vista ideológico señalan las posibilidades de las manipulaciones del poder (tanto para el colonizador como para el colonizado). De ahí que Lefebvre advierta que el sistema propicia esas tomas de consciencia. Es por eso que bajo el colonialismo se negocian las identidades (Del Toro); rasgo que precisamente caracteriza a los ensayos caribeños.

Un ejemplo del entramado de nexos dados en el Caribe está en la relación que existe entre el discurso de Castro y la propuesta de Ortiz. Ambos cubanos aluden al pasado para validar su punto de vista. Por eso la historia sirve como metáfora cultural: representa su autoridad por encima del sistema dominante y de las dinámicas que se producen. Castro utiliza la historia para legitimar el intercambio simbólico del poder, con la posibilidad de que éste pueda estar en manos de la masa. Igualmente sucede con la figura de Calibán, que bajo la mirada de Lamming y Retamar se entrevé que los eventos históricos propician la permutación del personaje (de Calibán); ya no es un Calibán víctima sino héroe, ya no es un Castro debatido sino un intérprete de los valores del pueblo cubano; ya no es un Caribe 
sometido sino uno que rebasa las condiciones que antes no habían sido cuestionadas. A este respecto, el elemento histórico mantiene vivo el pasado y da la posibilidad de crear consciencia acerca de éste. La figura de Calibán representa un pasado de sometimiento, pero igualmente incita a la reapropiación y la lucha. Así, las constantes vueltas y contingencias que existen al (re)interpretar un símbolo está enlazado de modo inevitable con las constantes reinterpretaciones de la historia.

La historia como metáfora cultural también trasluce en las demás propuestas epistemológicas. Una particularidad que vale la pena señalar es que la historia marca la trayectoria del ser humano en la sociedad, por lo tanto, hablar de la libertad del ser humano es hacerlo de acuerdo a los eventos históricos que confrontan esas ideologías libertadoras. Así, tanto en Castro como en Césaire se vislumbra la creación de un discurso que coherentemente conecta puntos de la historia para discutir debates del presente. En ambos planteamientos se demanda un cambio político-social 'real' a través de sus construcciones retórico-discursivas.

En ese mismo encadenamiento de eventos históricos se explica la criollización. La mezcla o mélage cultural entre las distintas etnias proyecta las interacciones que se dieron y contribuye a la acumulación de elementos que ulteriormente forman aún más heterogeneidad. Cada una de las culturas que coincidieron (y coinciden) en el espacio del Caribe lleva a cabo un papel dinámico, se manifiesta de acuerdo a sus respectivas tradiciones y conecta con otros componentes, transformando simultáneamente la cultura actual. De esta manera, Brathwaite señala que para comprender la cultura caribeña debe hacerse a través de acercamientos interdisciplinarios dadas las complejas y múltiples partes que la componen. Los ensayos de Brathwaite, asimismo, constatan que la criollización es paralela a la globalización. En ambos casos se trata de procesos y resultados del acaecer histórico. Por lo tanto, la globalización se 
observa bajo los mismos términos que se estudian las metáforas caribeñas, se entienden a través de las conexiones de dichos procesos y las relaciones de poder que se dan en estos.

Brathwaite explica la criollización como un proceso de la cultura del Caribe en el que se ilustra una integración social. Sin embargo, ulteriormente resulta en desintegración puesto la complejidad de factores y fuerzas encontradas. Por eso el concepto funciona como espacio de integración cultural o de búsqueda de una identidad en común, pues, sirve para disfrazar una más acentuada desintegración social, lo que es lo mismo, desplazamientos y transformaciones de la cultura. Un ejemplo que ilustra esta dinámica de unión-digresión está, de acuerdo a Brathwaite y Jiménes-Grullón, en la música y el baile. Benítez Rojo también afirma que la música, el baile, incluso el teatro, entre otras expresiones artísticas (estéticas), representan el Caribe. Conjuntamente, Díaz Quiñones extiende su idea a las formas de la vida diaria en general. Así, entre todos estos, se manifiesta una compilación cultural en los espacios de creatividad o cotidianidad. La arbitrariedad de la música y el baile permite la intersubjetividad y consolida la heterogeneidad. Por esto mismo es que la propuesta de Ortiz se presenta a través de la dinámica contrapuntística (un término evidentemente musical).

Con la música además se representa el contacto entre clases sociales. En un plano simbólico y literario, los modelos culturales que enlazan sus ideas apuntando a expresiones musicales (y de bailes) buscan mostrar zonas intangibles que ilustran un espectro continuo (Brathwaite) de las disposiciones inter-sociales, interraciales e interculturales. La 'realidad' se transforma a través de las expresiones artísticas de acuerdo a las posibles combinaciones y conexiones sin resultar en una composición desordenada de ideas. Al contrario, tanto la música y el baile como la literatura, en particular las propuestas ensayísticas analizadas, representan la capacidad de compilar metódicamente imágenes/sonidos/movimientos que se traducen en lo que es el proceso y desarrollo cultural caribeño y su tradición. 
Otro recurso metafórico apropiado para entender la cultura es el lenguaje. En el Caribe, el créole representa una actitud de enfrentamiento contra las condiciones políticas, sociales y económicas que se dieron en el sistema colonial de la Plantación. Los lingüistas Devonish y Bickerton consideran que el créole y sus funciones en la sociedad representan el resultado de las condiciones de vida. Aunque Bickerton examina la génesis y las condiciones del créole en la sociedad de hace más de cinco siglos y Devonish estudia el lugar que ocupa el idioma al momento de su publicación (1986), ambas perspectivas reconocen el poder simbólico del nacimiento y evolución de un nuevo idioma en estas sociedades. Se refleja asimismo el complejo proceso cultural de los habitantes de cada isla. Esto significa que funciona igualmente como medio para el conocimiento de la cultura del Caribe, en general y en particular. Para que el créole continúe su desarrollo lingüístico, dice Devonish, no debe restringirse su uso, es decir, que no exista la imposición de un idioma oficial (de herencia colonial). Esto debido a que de ahí surge la diglosia y así también las marcadas diferencias y tensiones de las funciones de los lenguajes en la esfera pública. Por consiguiente, gran parte de la sociedad de habla créole se enfrenta a condiciones supeditadas al idioma de las instituciones gubernamentales, educativas, etc. Se dificulta, asimismo, la expresión creativa e incluso la productividad mercantil entre los miembros de las comunidades (Devonish 35). Por lo tanto, la imposición de una lengua oficial marca limitaciones u obstrucciones de la libertad.

El lenguaje funciona para establecer sinnúmeros de enlaces figurados. Esto sucede porque la lengua reúne lo externo en su propio espacio posibilitando así lo simbólico (para Mignolo es el 'decir'). Es ahí que se permite convertir lo ajeno en propio. Sucede de la misma manera en la cultura, sobre todo, en el contexto colonial, puesto que los grupos sociales se encuentran en constante negociación, en la conducción de estrategias de supervivencia (como 
lo es el lenguaje mismo). La existencia y uso del idioma créole representa entonces no solo libertad creativa sino también la sobrevivencia de duras condiciones de vida. Por eso, por un lado, Glissant señala la importancia de la lengua para representar la pluralidad cultural del Caribe y, por otra parte, Condé confirma que esa misma representación plural está en la conexión entre el créole, la tierra (espacio geográfico), el pasado (la historia) y los individuos. De ahí que el idioma simbolice la interconexión que posibilita una construcción de la identidad colectiva del espacio antillano (y que según Glissant se incluyen también las islas que no hablan créole). Inclusive, los créolistas también lo establecieron: utilizar el créole (sobre todo en el plano de lo creativo) presume un acto de reapropiación de sí mismo, a saber, de la propia identidad.

Condé, sin embargo, alega que la reapropiación antes indicada es limitante. Al instaurar parámetros literarios bajo un único idioma restringe la libertad o la creatividad. Esta misma idea la desarrolla Devonish pero en referencia a la esfera social en general. Recordemos que el académico indica que la liberación cultural no puede existir si se impone un idioma. Aunque en ambos casos se habla de las consecuencias de la imposición de dos idiomas distintos (europeo -inglés, francés, holandés, etc.- y créole) y de las diferentes funciones que cada uno tiene en la sociedad, los dos coinciden en cómo esto afecta las posibilidades (libertades) creativas, culturales y de las relaciones humanas en general.

Las propuestas teóricas de la cultura caribeña en la última década del siglo XX establecen varios nexos con los planteamientos creados las décadas anteriores. De hecho, Benítez Rojo reconoce las conexiones con otros autores, indica que les debe, específicamente, a Ortiz, C.L.R. James, Césaire, Brathwaite, Glissant, entre otros. Advierte además que todas las exploraciones sobre el tema de lo caribeño "está[n] destinada[s] a ser una continua búsqueda" (Benítez Rojo). De ahí que esta incesante búsqueda signifique las relecturas, las miradas a 
las contingencias de acuerdo a los distintos acercamientos y metodologías utilizados. Así, el autor cubano denomina la cierta manera para señalar una especie de conjugación aleatoria de elementos múltiples que establece patrones repetitivos que pueden identificarse como representaciones culturales. De acuerdo a Benítez Rojo, para comprender la conglomeración de dinámicas que existen en el archipiélago hay que recurrir a constantes relecturas del espacio 'real' y metafórico. Por esto el autor señala la teoría del caos como ideal para representar los patrones, repetitivos y simultáneamente diferenciados, en el espacio y tiempo en el que se ven las transformaciones culturales en el Caribe.

A propósito del enfoque de Benítez Rojo sobre el espacio 'real' y 'metafórico', vale indicar que éste pasa de la noción 'real' geográfica a sostener divergencias simbólicas que resultan de dicha constitución física. De modo similar Pedreira utiliza la forma geográfica de la isla de Puerto Rico para señalar tropos que identifican al país y sus habitantes. Sin embargo, el primero determina que la formación archipielística define lo caribeño positivamente (apertura, fluidez, dinámicas ilimitadas, libertad), mientras que para el segundo, ser isla es limitante (encoge, estrecha, restringe). Se establece entrambos una dialéctica entre lo geográfico y lo identitario, en la que también entran las discusiones de Glissant (que indica la naturaleza abierta del Caribe).

El texto de Benítez Rojo constituye la misma apertura de la que habla Condé. Ambos ensayos se enfocan en el elemento de lo estético, ya sea la música o el baile, entre otros, o la literatura. No obstante, también la apertura está presente en Díaz Quiñones que con el análisis de los usos del bregar propone un espacio abierto hacia un mundo de posibilidades. Se negocia así lindar e interaccionar en otras esferas que bullen en el mismo movimiento oscilante y repetitivo de las Antillas. Ahí está la búsqueda de la libertad; en Benítez Rojo es un acto de cadencia, en Díaz Quiñones una retórica de lo potencial, de un desenvolverse 
estratégicamente, y en Condé la contravención del orden (Condé 164). Esta última propone la validación de la voz femenina y la de la juventud en las creaciones artísticas caribeñas. Por eso los ensayos que dan cierre al siglo muestran ahínco en esa apertura o liberación de un orden establecido. Por otra parte, el carácter abierto, visto desde lo figurado, además nos habla de lo caribeño accediendo a formar parte del resto del mundo, es decir, de inscribirse en un plano global.

Claro está, todas estas propuestas se relacionan estrechamente con el inicio que este trabajo escoge, es decir, con la metáfora de Césaire. Recordemos que el autor martiniqués hace hincapié en la juventud. De hecho, esto incluso también lo hace Castro. Todos estos escritores, en fin, tienen el propósito de exigir la libertad en diferentes grados.

La forma del ensayo permite de esta suerte amplificar las posibilidades de la metáfora, es decir, los niveles de libertad. Primero porque el ensayo juega con la noción tradicional de la verdad (Adorno), por lo tanto permite su manipulación. En segundo lugar, debido a que esta misma (la verdad) es subjetiva y por lo tanto manifiesta contingencias metafóricas (Ricoeur). Por eso este género literario admite la transferencia de propiedades de los conceptos según se presente el discurso y la intención del escritor. De ahí que la forma ensayística permita desplazar las contradicciones que se presentan y que generan postulados que incluso sean enigmáticos. Por ejemplo, esto está presente en el modelo de bregar, ya como negociación ya como mecanismo que entrevé movimiento, así como en el prototipo cultural que describe Glissant. Precisamente, éste señala que la identidad caribeña es enigmática, específicamente, alude a que es obscura, lo que en Benítez Rojo es lo inexplicable.

La construcción de espacios simbólicos que permiten estas transacciones culturales en el Caribe dejan de ser meras representaciones para consolidarse como epistemologías. Esto es, los patrones que proyectan las metáforas estudiadas conceden un conocimiento cultural a 
partir de nociones raciales, históricas, socio-culturales y lingüísticas, y dan un apertura para la interconexión de todas éstas. Así, las posturas ideológico-metafóricas de estos autores caribeños revelan el carácter múltiple y poco convencional del Caribe. Hoy día, sin embargo, son consabidos los diversos modos de mirar el espacio antillano y, por lo tanto, esto ayuda a ilustrar una asociación con lo externo, o mejor dicho, con lo global cultural. Ahí mi contribución al campo: las propuestas de los ensayos caribeños presentados funcionan como recurso retórico. Todas estas construyen una ilación de pensamientos (conocimientos) que consienten renovadas conexiones, mismas que continúan repitiéndose, como lo colectivo como la historia como la cultura. 
Notas:

${ }^{1}$ A partir de la década de 1930 hasta el fin del siglo.

${ }^{2}$ El comienzo del primer gran intercambio cultural se da en 1492, con la llegada de los europeos a las "nuevas tierras americanas".

${ }^{3}$ Fuente tomada en línea de: http://www.ensayistas.org/critica/ensayo/gomez/. Refiérase a la lista de referencias para más detalles.

${ }^{4}$ Entre los principales filósofos europeos que influyen los pensadores del siglo XIX en América latina están Auguste Compte (positivismo), Arthur Schopenhauer (pesimismo/ optimismo paradójico, idealismo alemán), Friedrich Nietzsche (pesimismo), Immanuel Kant (idealismo alemán), Georg W. F. Hegel (idealismo alemán), Alexander von Humboldt (naturalista), Jeremy Bentham (padre del utilitarismo), John Stuart Mill (utilitarismo), y Ernest Renan (elitista-aristocrático/ racionalismo). Aunque es necesario señalar que el pensamiento europeo difiere del positivismo que se da en América latina, pues este último fue interés esencial de una oligarquía de grandes terratenientes (Octavio Paz, Los hijos del limo (1974), 127).

${ }^{5}$ Entre los autores más destacados del positivismo y del modernismo latinoamericano están Simón Bolívar, Andrés Bello, Domingo Sarmiento, José Enrique Rodó, José Martí, entre otros.

${ }^{6}$ La otra función que señala Cruz-Delgado es “la de la narrativa, propiamente dicha, que es diegética” (71).

${ }^{7}$ El nuevo imperio, o "el gigante de siete leguas”, al que Martí alude es la reciente nación norteamericana de los Estados Unidos. Aquí el autor, a modo de predicción, intuye la expansión territorial y económica que ese gigante norteamericano adquiere luego en el siglo XX.

${ }^{8}$ Cabe señalar que la concepción de la Federación antillana no sólo se reduce al desarrollo intelectual e ideológico del plan, si no también que busca armar al pueblo para luchar en contra del imperio español. En una de tantas ocasiones en que Betances menciona esta intención, en la correspondencia escrita que mantiene con el Dr. J. Julio Henna, señala su deseo: "Para hacer algo allí se necesitan: $1 .^{\circ}$, tener fondos; 2. ${ }^{\circ}$, preparar las masas; $3 .^{\circ}$, introducir armas” (Betances 188); “...y no sé si se decidirá a mandar el importe de la ametralladora" (206); "Estamos luchando en las mismas condiciones con que pelea el soldado cubano, que no tiene más que un machete contra el Máuser y el revólver. ¡Palante! ¡Siempre!” (231), etc.

${ }^{9}$ Aunque las propuestas de este capítulo se publican en una década en lugar de 15 años, resulta igualmente viable utilizar la ordenación establecida según Goic. De hecho, resultaría en posibilidades de investigación en el estudio de los ensayos de los primeros cinco años del siglo XXI, como parte del cierre de la generación literaria de 15 años y, con esto, se muestra también la ensayística que cierra y abre los siglos y los milenios.

${ }^{10}$ Durante más de veinte años, la crítica determina que Senghor y Damas desaciertan cuando hacen estas afirmaciones sobre la aparición inicial del término. Según Edward Ako en "L'étudiant noir and the Myth of the Genesis of the Negritude Movement”, el único número de la revista conocido al momento de su estudio no da muestra del uso del término. Ako contradice a Lilyan Kesteloot, quien afirma que el concepto sí nace en dicha revista, esto sin haber tenido en sus manos ninguno de sus números. Sus conclusiones se basan en las entrevistas hechas a Damas y a Senghor, pero no confirma que en efecto el término aparece en el único número de L'étudiant noir conocido al momento de su análisis. A partir de las aseveraciones de Ako, durante décadas es unánime el consenso de la crítica, según el cual el concepto aparece por primera vez en la famosa obra poética césariana Cahier d'un retour au pays natal (1939) y no en la revista académica como lo indicara Kesteloot. Christian Filostrat y Christopher Miller 
luego contradicen las afirmaciones de Ako y de otros críticos. En el 2008, Filostrat demuestra que existe otro número de la revista, que ésta contaba con más de un ejemplar en circulación en París en 1935 y que es ahí donde consta el término y no en su famoso poema: “...Filostrat published a book that contains negritude's missing link: an article by Césaire in L'étudiant noir, number 3, May-June 1935” (Miller 743). En el 2010, Miller analiza el ensayo de Césaire encontrado por Fiolostrat. Por lo tanto, L'étudiant noir en uno de sus números (no se publica un solo número de la revista académica sino tres), tal como Senghor y Damas lo confirman, en efecto contiene la primera aparición de négritude en el ensayo "Conscience raciale et révolution sociale" (mayo - junio 1935). No obstante, para el propósito de este trabajo es de importancia el artículo de Césaire que le antecede a éste, "Négreries, Jeunesse noire et assimilation" (marzo 1935), pues es en éste donde el autor advierte su intención como estudiante revolucionario y, así, fija la génesis del concepto, incluso antes de acuñarlo meses después. De todos modos, hay que reconocer la importancia de otros textos en relación al propósito de négritude. Sobre esto, Doris L. Garraway afirma que es en Cahier d'un retour au pays natal (1939) en donde Césaire teoriza concretamente sobre el vocablo: “...[it] is the ... most elaborate theorization in poetic form of the term négritude" (73).

${ }^{11}$ En el discurso pronunciado por Césaire en Dakar el 6 de abril de 1966 en la apertura del primer "Festival mondial des arts nègres”, el autor resume la importancia del arte en la négritude: « Par l'art, le monde réifié redevient le monde humain, le monde des réalités vivantes, le monde de la communication et de la participation. D'une collection de choses, la poésie est jeunesse. Elle est cette force qui redonne au monde sa vitalité première, qui redonne à chaque chose son aura de merveilleux en la replaçant dans la totalité originelle. Si bien que sauver la poésie, sauver l'art, c'est en définitive sauver l'homme moderne en personnalisant et en revitalisant la nature » (Césaire).

${ }^{12}$ Senghor escribe acerca de la négritude en el prefacio al libro de Jean-Paul Sartre, Orphée noir (1948), y luego éste prologa a Senghor en una antología. La crítica de Souleymane Diagne en "Négritude” añade que surge: "...by emphasizing the particular and the concrete of race over the objective and the universal of the struggle against capitalism and imperialism...". Para añadir a lo indicado: "The paradox of Sartre's preface to the Anthology by Senghor is that in many respects the Négritude movement had, after Black Orpheus, to define itself against Sartre's positioning of its philosophical meaning. It did so (1) by insisting that it was not a mere particularism defined as the antithesis to a white supremacist view (with black self affirmation using the figure of inversion that Sartre characterized as an anti-racist racism (1976, 59)),before some dialectical post-racial synthesis; (2) by showing that there was something substantial (and not just poetic) in the reference to African values of civilization... ” (Diagne 7).

${ }^{13}$ Lo ahora citado por García Platero es tomando de lo que dice André Goose en su artículo "De I'accueil au refus". La Banque des Mots 1 (1971). 37-44

${ }^{14}$ García Platero cita directamente a Vidal Alba de Diego (355) en su artículo "Marcas, abreviaciones y siglas en el lenguaje publicitario”. Prohemio 4 (1973). 349-378.

${ }^{15}$ Lugar en donde estaban encerrados los esclavos negros (mi traducción), tomado del diccionario: http://dictionary.reverso.net/french-definition/négrerie.

${ }^{16}$ Para Galloway el significado preciso del concepto permanece ambiguo en el poema de Césaire, pues, para ésta, al igual que para la mayoría de la crítica, el poeta define el término a través de una imagen surrealista del poema (que surge a través de una noción europea). Ahí, se compara lo negro como naturaleza orgánica y las fuerzas irracionales del universo en contraste con la materia inerte o inmóvil del pensamiento occidental. Por esto, el análisis de la intención césairiana no siempre proviene de la observación de la raíz que forma négritude.

17 Sobre esto es preciso añadir que Soyinka considera la propuesta de Césaire como un humanismo africano de especificidad racial, según dice Kelly M. Yamanouchi: "In his speech, titled "Negritude: 
The Poet as Mediator and Accuser," Soyinka discussed "négritude," which he defined as "race-specific African humanism" (20-22).

${ }^{18}$ Según Petri Liukkonen, "A number of Soyinka's essays were collected in Myth, Literature, and the African World (1976). He has been one of the most outspoken critics of the concept on négritude, which have been associated with Léopold Senghor, the writer and former President of Senegal. Soyinka sees that négritude encourages into self-absorption and affirms one of the central Eurocentric prejudices against Africans, namely the dichotomy between European rationalism and African emotionalism. "A tiger does not shout its tigritude," Soyinka said, "it acts." In his essay 'Reparations, Truth and Reconciliation' (in The Burden of Memory, the Muse of Forgiveness, 1999) Soyinka defends the idea, that the West should pay reparations for crimes committed against African people. "Reparations... serve as a cogent critique of history and thus a potent restraint on its repetition." Soyinka points out that this discussion is not new, but Pan-African organizations talked about compensation in the beginning of the 20th century” (Tomado el 26 de marzo de 2013 de (http://www.kirjasto.sci.fi/soyinka.htm; mi énfasis).

${ }^{19}$ Coulthard basa parte de su análisis, citando a Jahn en "Muntu, an outline of neo-African culture", quien estudia las aseveraciones de Sartre y otros críticos sobre la négritude.

${ }^{20}$ Rachid. “Negritud, monería y mistificación”. Habana: Casa de las Américas Año VI 41 (marzo-abril 1967). 110-15, 112.

${ }^{21}$ Se estudia el punto de vista crítico de Condé frente a la propuesta teórica de Glissant en el capítulo 5 de este trabajo.

${ }^{22}$ Éste habla del concepto négritude en una biografía sobre Césaire que escribe en colaboración con Simone Henry-Valmore.

${ }^{23}$ Algunos de los críticos que estudian la visión de Senghor son Stanislas Adotévi (1972) y Jean Paul Sartre (1948) en "Orphée Noir".

${ }^{24}$ Said afirma también que un antecedente al movimiento es el trabajo de WEB Du Bois en The Souls of Black Folk (1903), ya que éste último alude a una toma de consciencia racial que puede "warn against a wholesale, indiscrimate attack on white or Western culture” (Said 215).

${ }^{25}$ Para un acercamiento a la mirada del universalismo, referirse al libro Colonialism and Cultural Identity de Patrick Colm Hogan, específicamente, en su introducción: "Identities and Universalism”.

${ }^{26}$ La idea del Otro la define Said refiriéndose a cualquier otra cultura que quede fuera de la occidental europea (Orientalismo 44-6).

${ }^{27}$ Aquí Césaire se relaciona con lo que Antonio S. Pedreira habla sobre la división de las etapas históricasculturales, específicamente en Puerto Rico. Para más información referirse a mi trabajo "Négritude", Insularismo y Discurso sobre el colonialismo: Modelos culturales caribeños en Césaire y Pedreira". El post Antillano. 3-30-2013: http://www.elpostantillano.net/pagina-0/critica-literaria/5045-diana-m-grullon.html

${ }^{28}$ El trabajo de Fanon es igual otra metáfora que parte de la propuesta de Césaire. Fanon crea otro modelo epistemológico de la cultura caribeña del siglo XX.

${ }^{29}$ Cuando me refiero al término subjetividades, se usa aquí en el sentido en el que Borges alude a las metáforas; éstas son vistas como parcialidades del ser.

${ }^{30}$ Puede notarse cierta influencia de José Enrique Rodó en Césaire. Ambos autores se dirigen a la juventud, a crear conciencia para cambiar la visión de la cultura. 
${ }^{31}$ Existe una crítica detractora sobre el término négritude que indica que hay una motivación directa con África de parte de Césaire, más no caribeña criolla [créole] (Confiant, ...). Pero en este caso, no puede perderse de vista que el yo del ensayo y del autor está explicito en el texto, y ese yo es caribeño. La respuesta creativa metafórica que surge luego de la propuesta de Césaire, y que se estudia aquí en el capítulo 5, son las que abarcan las ideas de la Antillanité y la Creolité como continuación de la négritude en cuanto a la construcción de modelos epistemológicos.

${ }^{32}$ Miller aquí cita directamente el ensayo de Césaire de "Conscience raciale et révolution sociale”.

${ }^{33}$ Más adelante se discuten los enlaces existentes con las propuestas marxistas y las relaciones de poder que genera el espacio para que los distintos sectores de una sociedad creen consciencia, resistencia y cambio social; esto surge tanto en Césaire como en Fernando Ortiz.

${ }^{34}$ En Lévinas también se trata de una idea metafórica. Éste la llama, "the face of the other".

${ }^{35}$ Pues, según éste, la ética y la consciencia son co-terminales. Para referirse a lo que alude Lévinas con el término 'co-terminal', ver la definición que da Kenneth J. Gergen en su libro Relational Being: Beyond Self and Community. New York: Oxford University Press, 2009.

${ }^{36}$ Incluso, Césaire abunda sobre su insatisfacción con algunas personas de la isla: "In the case of Césaire that feeling was expressed in his detestation of Martinique which, as he confessed in an interview with Françoise Vergès, he was happy to leave after high school: he hated the "colored petit-bourgeois" of the island”; esto sucede fundamentalmente por la tendecia a imitar a Europa (Diagne).

${ }^{37}$ Sobre esta arbitrariedad de las palabras y de los conceptos, de la relación de los significados con los significantes, en la cuestión de que la unidad lingüística es una entidad doble formada por la asociación de dos términos, relacionados con la imagen y el sonido de lo nombrado, lo estudia Ferdinand de Saussaure en "Curso de lingüística general". Cabe señalar que en el análisis que se presenta en el próximo capítulo sobre Fernando Ortiz se alude igual a la parcialidad de la lengua.

${ }^{38}$ En esa recuperación histórica del poeta, a favor de crear dentro de los parámetros de lo que ya se ha establecido como la négritude, en el poema Cahier d'un retour au pays natal el autor muestra en sus versos que existe dignidad en ese largo sufrimiento de la esclavitud. Su trabajo presenta la humillación que conllevó para las personas que fueron parte de eso y, al mismo tiempo, quiere liberar de la mentira de la misión civilizadora del colonialismo en la que habían denominado como bárbaros a los negros (Garraway 73).

${ }^{39}$ La poesía negrista, "Supone la incorporación al poemario hispanoamericano del sustrato africano o negro que es esencial en la zona del Caribe. En español y sobre temas y ritmos afroantillanos se elaboró una poesía musical, sonora de gran expresividad plástica. Surge a partir de los años veinte, con la particularidad de que los autores en su mayoría son de origen negro o mulato”. (Nicolas Guillén, Cuban Poet. Books on Cuba. 7 March 2010: http://www.nathanielturner.com/nicolasguillen.htm)

${ }^{40}$ Duno Gottberg, Luis. Solventando las diferencias: la ideología del mestizaje en Cuba. Fuente tomada en línea.

${ }^{41}$ Con este último libro, el poeta puertorriqueño fue premiado.

${ }^{42}$ La poesía mencionada en este apartado se le conoce también como poesía negra, negroide mulata, afroamericana, afroantillana y afrocubana. Éstas se denominan como composiciones cultas en las que el tema del negro juega el papel del folklorismo. Los representantes más importantes son Pales Matos y José Manuel Poveda; éste último, cubano que "combinó composiciones simbolistas con cuadros de poesía afroantillana". Cuando la literatura se considera de raíz popular, en la que el hablar del negro es un elemento esencial, 
destacan Alejo Carpentier, Guillén y Emilio Ballagas (cubanos). Éste último incorpora costumbres con matices populares y temas sugestivos locales; entre sus obras está Cuadernos de poesía negra, Antología de la poesía negra hispanoamericana. Hay que señalar que luego de los años treinta, Guillén se inclina por un contenido social y político mucho más evidente, tomando especial atención al mismo propósito de Césaire: la rehabilitación [emancipación] y la equiparación del hombre negro con los demás. Para leer más sobre Guillén consultar: Motivos del son; Songoro cosongo, West Indies Ltd., La paloma del vuelo popular y, su libro más importante, El gran zoo.

${ }^{43}$ Sobre la literatura universal existe, por otra parte, sinnúmero de debates en la teoría literaria. Entre éstos se encuentra el trabajo de Harold Bloom, El canon occidental. Aquí solo se utiliza para hacer hincapié a la posición que ocupa el texto de Césaire en el Caribe y cómo esto se relaciona con la construcción de la négritude como metáfora cultural.

${ }^{44}$ Nótese que el poeta y su movimiento aparece en The Columbia History of Tewentieth-Century French Thought. Edición de Lawrence D. Kritzman. New York: Columbia University Press, 2006.

${ }^{45}$ Ortiz y Malinowski eluden otras posibles definiciones que son igualmente válidas y aceptadas por otros estudiosos. Según Santí, Redfield, Linton y Herskovitz, aculturación no significa precisamente que el 'inculto' esté privado o que niegue su cultura por la dominante (como Ortiz y Malinowski prefieren), sino que es un fenómeno resultante del choque de individuos de distintas culturas que están en continuo contacto directo, surgiendo cambios culturales de uno o ambos grupos (Santí 85).

${ }^{46}$ De acuerdo con Jossianna Arroyo en "Travestimos culturales: tropicalismo y transculturación en Gilberto Freyre y Fernando Ortiz”, el autor cubano presenta su argumento a través "del lenguaje [en el que] el narrador logra la plasticidad de su representación y crea a su vez los sistemas de negociación necesarios para posicionar a ese sujeto que narra (frente a Europa, frente a sus otros)” (Arroyo 29).

${ }^{47}$ Ortiz cuenta con el apoyo de Malinowski. Pero, este patrocinio es puesto en duda en el estudio que hace Fernando Coronil en la introducción a la versión inglesa del Contrapunteo.... Éste provee un análisis muy interesante que marca la diferencia entre ambos antropólogos respecto al punto de enunciación que adoptan. Para más detalles referirse a la sección del trabajo de Coronil: "Counterpoints of Theory: Malinowski and Ortiz” (xxx-xxxv).

${ }^{48}$ Este término se utiliza aquí de acuerdo a la definición que J. Arroyo presenta con el concepto de travestismo cultural. Ésta indica que es "una estrategia a través de la cual el (la) escritor(a) se enmascara como sujeto para realizar un juego de alianzas, subordinaciones y acercamientos sinuosos con la otredad negra que está representando” (15). Con esto, no hay que perder de vista que también Ortiz presenta la otredad indígena a partir de la representación del tabaco (ver más adelante).

${ }^{49}$ Arroyo también habla del carácter contradictorio que presenta Ortiz con su concepto, esto incluso a pesar que el escritor busca, precisamente, eliminar dicha indeterminación.

${ }^{50}$ Santí explica, en una nota al pie de página, que en el ensayo de Ortiz, “A su vez, el contrapunteo se relaciona, musicalmente, con el contrapunto musical, o diálogo entre dos o más instrumentos. Es evidente que Ortiz opta por el término cubano tanto por su nacionalidad como por su carácter polémico. Igualmente enfatiza que esas controversias o contrapunteos ocurren...” en distintas formas musicales cubanas como el punto güajiro, la güajirada montuna o la currería afro-cubana (136). Del mismo modo, se asemeja a otras formas musicales de las tradiciones caribeñas hispanas, por ejemplo, las de República Dominicana y Puerto Rico.

${ }^{51}$ Esta es una de las razones por las que la crítica postmoderna (Benitez Rojo, Coronil) ha señalado el Contrapunteo... de Ortiz como proto-posmoderno o avant la lettre. 
${ }^{52}$ Como se adelanta en la introducción, este trabajo de Benítez Rojo es examinado en el capítulo 6 del presente estudio.

${ }^{53}$ Coronil advierte que el carácter alegórico del texto está asociado con las condiciones de la recepción al momento de ser publicado: "Ortiz's book in 1940 occurred at a time of international and domestic upheaval which frames the concerns of the text and helps explain its allegorical character" (xi).

${ }^{54}$ Precisamente, interesa señalar que Antonio Cornejo Polar y J. Arroyo apuntan esta inviabilidad en Ortiz, indicando que éste busca armonía en donde no existe. En el caso de Benítez Rojo, al contrario, las afirmaciones que hace son precisando estas imposibilidades infinitas, pues, para éste, el autor no trata de resolver armónicamente la dinámica y las relaciones de poder que el texto presenta.

${ }^{55}$ Referirse al texto de Jorge Ibarra, "La herencia científica de Fernando Ortiz" para abundar sobre la relación de la transculturación con los sistemas de creencias del negro. Ibarra indica que, "Las reiteradas alusiones etnocéntricas a la amoralidad de las concepciones religiosas y sociales de los afrocubanos, rectificadas posteriormente en las décadas del treinta y del cuarenta, nos revelan la óptica desde la cual Ortiz enjuiciaba el proceso de transculturación. No bastaba ser cubano para reconocer científicamente, mediante un esfuerzo de empatía, los valores de los afrocubanos. En las tres primeras décadas del siglo XX, Ortiz no había alcanzado aun la visión superior que le permitiese integrar simultáneamente, desde 'el exterior' y desde 'el interior', el mundo mágico de los afrocubanos en un sistema conceptual apropiado” (1340).

${ }^{56}$ Coronil advierte que, "Rather than straightforwardly offering an argument, it worked tangentially through poetic allusion, brief theoretical comments, and a detailed historical interpretation" (xi-xii).

${ }^{57}$ Para referirse a la situación política nacional e internacional al momento de la publicación del texto de Ortiz, ver el trabajo de Coronil, pues, éste indica que "Ortiz offered Cuban Counterpoint as his own response to the critical circumstances of his time” (xvi). Y también habla sobre la ideología política del autor: "As a liberal democrat who had seen the failure of liberal democracy in Cuba and elsewhere, Ortiz could find little hope in a democratic option for Cuba in 1940" (xv). El crítico alude igual a que, "A number of intimately related processes, in which globalizing forms of capital accumulation and communication are met both with transnationalizing and reconfigured nationalist responses” (xii).

${ }^{58}$ Consuelo Naranjo-Orovio añade en "Cultura, identidad y nación en las obras de Fernando Ortiz y Antonio S. Pedreira”, que al igual que Ortiz, Pedreira interpreta la historia para afirmar la nación y la cultura puertorriqueña. En Pedreira, sus estereotipos y prejuicios se incorporan en la mentalidad del pueblo: "Aunque la aproximación e interpretación del pasado y de la historia es muy diferente en Pedreira y en Ortiz, la afirmación de la nación y de su integridad a partir de la cultura, ... Sus ideas, estereotipos e imágenes fueron incorporadas no sólo a la «historia oficial» tras su aceptación y uso por historiadores, antropólogos, sociólogos o literatos, sino también a la mentalidad popular, esto es, a la manera de concebirse a sí mismo el pueblo cubano y puertorriqueño, y de proyectarse al exterior” (163).

${ }^{59}$ El concepto de transculturación se relaciona también con la noción de sincretismo cultural de Alejo Carpentier. El sincretismo se refiere al crisol o mezcla de las distintas culturas, en las que ninguna queda superpuesta a otra. Más adelante, en el cuarto capítulo de este trabajo se abunda un poco acerca del término de Carpentier en relación con el vocablo de criollización.

${ }^{60}$ Acerca de estas "intrincadísimas transculturaciones", Alfonso del Toro hace un breve bosquejo en su artículo "Figuras de la hibridez. Fernando Ortiz: transculturación. Roberto Fernández Retamar: Calibán”. Para más información referirse a este trabajo (24).

${ }^{61}$ Como es sabido, la desaparición de los indígenas en las Antillas, igualmente, surge debido a otros factores, como por ejemplo el contagio de enfermedades que trajeron los europeos y que eran mortales 
para los aborígenes (los habitantes en América no estaban preparados -no tenían anticuerpos- para combatir dichos problemas de salud).

${ }^{62}$ Aquí, la alusión a la masculinidad de la planta advierte que las nociones de género están expuestas en la propuesta de Ortiz y que sirven para el análisis de su obra. Sobre esto, Coronil y Arroyo fundamentan algunas de sus interpretaciones. Por una parte, el primero añade que el autor tiende a naturalizar al tabaco (y al azúcar): “...to naturalize gender and to use common values associated with the masculine and the feminine as standards for valorization. Tobacco tends to be masculine and to represent the more desirable features in Cuban culture; sugar, in contrast, stands for the feminine and represents the most destructive features of foreign capitalism" (xxii). Por otro lado, Arroyo presenta su trabajo sobre Freyre y Ortiz alrededor de estas nociones de género (y de raza): "Lo masculino, sin embargo, trabaja.... como una construcción social en la que se crean poses y se construye el imaginario cultural de la cubanía”. Igual, ésta adiciona que, "En estas representaciones se produce, a nivel textual, una atracción erótica muy particular en la que la sexualidad, el género y la raza conforman un imaginario de "atracción-repulsión" de lo femenino que constituye la cultura cubana como una alianza masculina"(27).

${ }^{63}$ Aun más, las herramientas o utensilios que se utilizan para inhalar o exhalar el humo del tabaco también funcionan como "simbolismo sobrenatural": tienen, según Ortiz, la "sonoridad que evoca la sacra vitalidad del espíritu del hombre a quien perteneció el hueso" que se utiliza como tubo inhalador (314). Igualmente, el uso del tabaco "les producía desvarío" (322), así que cada usuario "busca la clase de tabaco que mejor le place, según sus gustos y temperamento para no emborracharse” (323) aunque en ocasiones existe el fin de obtener "experiencias visionarias"(330).

${ }^{64}$ Interesa ver cómo los capítulos del azúcar siguen un orden secuencial, hasta que la estructura se interrumpe en la sección XIX en la que se adscriben, otra vez, otros cuatro capítulos que retoman el tópico del tabaco. El producto azucarero regresa como temática principal, nuevamente, después de estos cuatro anteriores, surgiendo dos últimos capítulos más, concernientes a este producto transportado de Europa. La obra culmina con una última sección del libro demostrando la legitimidad del tabaco habanero. Claramente, esto ilustra la forma contrapuntística de la estructura alegórica que adopta el autor.

${ }^{65}$ Aquí hay una relación con el estructuralismo de Ferdinand de Sausurre.

${ }^{66}$ Rama advierte que en América se construye dicha armonía a través de un lenguaje simbólico en la literatura: “...en la originalidad de la literatura latinoamericana está presente, a modo de guía, su movedizo y novelero afán internacionalista, el cual enmascara otra más vigorosa y persistente fuente nutricia: la peculiaridad cultural desarrollada en lo interior,... [por] el esfuerzo ingente de vastas sociedades construyendo sus lenguajes simbólicos” (Rama 17).

${ }^{67}$ La metáfora del ajiaco, planteada por el mismo Ortiz, sirve para aludir a la hibridez de la cultura cubana; igual sucede con el concepto de transculturación (ambas metáforas creadas en 1940).

${ }^{68}$ Sobre esto, Cornejo Polar añade que "El mestizaje, pese a su tradición y prestigio es el que falsifica de una manera más drástica la condición de nuestra cultura y literatura. En efecto lo que hace es ofrecer imágenes armónicas de lo que obviamente es desgajado y beligerante, proponiendo figuraciones que en el fondo solo son pertinentes a quienes conviene imaginar nuestras sociedades como tersos y nada conflictivos espacios de convivencia” ("Mestizaje...” 7-8; mi énfasis). Del mismo modo, Díaz Quiñones sostiene que el trabajo de Ortiz propone una "poética [que] intenta armonizar formas de pensamiento opuestas” (Díaz Quiñones 306).

${ }^{69}$ La crítica ha señalado que los cronistas son el primer ejemplo de la heterogeneidad cultural de América, pues la mención de una nueva realidad implica un doble movimiento “...con lo que queda en claro que hasta la más escueta descripción tiene que procesarse dentro de un orden comparativo que acude a la 
experiencia de una realidad que no puede ser la del referente" (Cornejo Polar, "El indigenismo...” 14). Aquí no se trata de un encubrimiento, más bien hay un intención de explicar que solo a través de las dinámicas de correlaciones culturales es que se adquiere una definición plausible de una epistemología cultural en América. De otra forma sería imposible lograr definir dichos proceso de intercambios o trances culturales.

${ }^{70}$ Aquí se agrega lo que Coronil asegura: “...a counterpoint among reader, writer, and language is forever at work", éste además indica que su análisis es un tributo al texto orticiano, "by engaging in this transcultural exchange, as Ortiz's book does, in counterpoint with the historical conditions of its own making” (xi). Por esta misma razón, el presente trabajo funciona bajo estas condiciones.

71 También, este análisis es viable al observar otro aspecto de la crítica de Cornejo Polar acerca del indigenismo en Latinoamérica. En este caso, "Se comprende que esta doble asimilación de intereses sociales y de formas estéticas, constituye el correlato dialéctico de la imposición que sufre el universo indígena del sistema productor del indigenismo: es... su respuesta" ("El indigenismo... 21). En el Caribe, los intereses sociales y las formas estéticas también establecen correlatos dialécticos.

72 "El quinto jinete del Apocalipsis", Conferencia de Ortiz en el Lyceum de la Habana el 9 de enero de 1951, publicada en la Revista Bimestre Cubana. La Habana: LXVII, no. 3 (mayo-junio): 1951. 193-213.

${ }^{73}$ Sobre esto, Godoy, citando a Varela, indica que “.... en Cuba, el problema del negro no es de resentimiento de inferioridad racial frente al blanco; el problema es social (Varela Ensayos)” (Godoy 243). No obstante, interesa reconocer que esta forma en la que Varela distingue "el problema del blanco" como social, en referencia a las clases sociales y los factores económicos que suscitan de dichas divisiones de clases, no crea desambiguación en la relación de los conceptos de raza y cultura.

${ }^{74}$ El brasileño Gilberto Freyre, con su concepto tropicalismo, ejerce una labor paralela a la que configuran Césaire y Ortiz. Sobre un análisis de este término, referirse al artículo ya citado de Jossianna Arroyo.

${ }^{75}$ Para un estudio sobre las concepciones de la nación en négritude, referirse al artículo de Dorothy E. Mosby, “"Nuevos nómadas”: Negritud y ciudadanía en la literatura centroamericana” (2008), y a Gary Wilder en The French imperial nation-state: Negritude and colonial humanism between the two world wars. University of Chicago Press, 2005.

${ }^{76}$ Sobre esto, Ricardo Ferrada en el artículo “Aimé Césaire: acción poética y negritud”, advierte sobre una generación de escritores que toman esta orientación sobre el negro: “...es innegable que escritores como Nicolás Guillén, Luis Palés Matos o Adalberto Ortiz, o antes Fernando Ortiz, Juan Marinello, fueron creando en nuestro continente, las condiciones para que en la década del 30 surgiera una articulación más explícita y, consecuentemente, más cohesionada y con mayores posibilidades de desarrollo de ese ideario virtual, producido desde la literatura de orientación negrista”. Así, tomando el ejemplo de Guillén, vemos que éste intensifica la presencia del negro en Latinoamérica: "His poetic visión was shaped by conditions during the late 1920's and early 1930's, when America sugar investment had become the basis of the Cuban economy” (Arrizón 142).

${ }^{77}$ Para añadir al análisis, Foucault advierte, “...que el poder viene de abajo;.... las relaciones de fuerza múltiples que se forman y actúan en los aparatos de producción, las familias, los grupos restringidos y las instituciones, sirven de soporte a amplios efectos de escisión que recorren el conjunto del cuerpo social. Éstos forman entonces una línea de fuerza general que atraviesa los enfrentamientos locales y los vincula; de rechazo, por supuesto, estos últimos proceden sobre aquellos a redistribuciones, alineamientos, homogeneizaciones, arreglos de serie, establecimientos de convergencia. Las grandes dominaciones son los efectos hegemónicos sostenidos continuamente por la intensidad de todos esos enfrentamientos" (56) . 
${ }^{78}$ Mi traducción

${ }^{79}$ De Toro amplía su concepción de las características físicas, aquí por ejemplo del color de la piel, en base al análisis “del 'cuerpo' como campo o categoría cultural, epistemológica, sexual, política y postcolonial” (21). Para profundizar sobre esta mirada, referirse al artículo aquí ya mencionado, sobre todo en las páginas 21-22.

${ }^{80}$ Ortiz adopta una estrategia que Marx también utiliza: “Like Marx, who by personifying Madame la Terre and Monsieur le Capital in Capital highlighted their fetishization in capitalist society (1981, 969), Ortiz simultaneously presents sugar and tobacco as consummate impersonators and unmasks them" (Coronil xxviii).

${ }^{81}$ Cabe mencionar que según Godoy estas mutuas influencias afectan mayormente al negro y que "esa transculturación del negro es transcendental para explicar lo cubano porque en toda Hispanoamérica -a diferencia de la colonización norteamericana, según también señala Carlos Octavio Bunge [en Nuestra América (1918)]-, la población africana se unió con los indígenas y con los criollos; de ahí que su influencia haya sido y siga siendo tan considerable, tanto para lo favorable (inmensa fuerza de trabajo, pugnacidad libertadora, aspectos culturales en el arte, en la religión y en la emotividad colectiva) como para lo pernicioso (sensualidad, acomodación, jugueteo, anarquía, incapacidad política, insurrección, abulia, exageración)” (Godoy 242).

${ }^{82}$ En Césaire, existe una constante alusión a la necesidad que hay de evitar la asimilación, que aquí llamo evitar convertirse en 'producto de masa', pues el negro corre el riesgo de la pérdida de su poder. Por lo tanto, el poeta martiniqués advierte que en lugar de asimilarse hay que emanciparse: tomando consciencia. En Ortiz, por otra parte, se alude a lo mismo, en la alegoría que surge de la personificación de los productos del tabaco y azúcar: "Tobacco, the symbol of Cuban independence, of exceptional skill and unique natural factors, appears now as an increasingly homogenized mass product controlled by foreign interests, like sugar" (Coronil xxviii; mi énfasis).

${ }^{83}$ Para conocer más sobre las implicaciones de los estudios de Ortiz, por ejemplo acerca de los académicos que influencian sus primeros trabajos, referirse nuevamente a la introducción de Coronil.

${ }^{84}$ Sobre este sentido de la necesidad de educar, respecto a Césaire, Miller dice: "In "Conscience raciale," as in Cahier, Césaire (or his narrator) is needed to help the black race find its voice. In short, negritude is needed" (745). Del mismo modo, en base a estas configuraciones culturales en el Caribe, Antonio S. Pedreira insiste en esta necesidad de educar a los habitantes de su isla. Para un estudio acerca de las connotaciones paternalistas que este otro escritor caribeño presenta, ver a Juan G. Gelpí en Literatura y paternalismo en Puerto Rico. Río Piedras: EUPR, 2005.

${ }^{85}$ Aquí no podemos olvidar que Ortiz es blanco, y que de esto se desprende una serie de críticas sobre la intención que tiene como académico blanco que busca enseñar al pueblo cubano mestizo.

${ }^{86}$ El juicio se celebra en un cuarto de hospital a puertas cerradas. Aunque ésta es la tercera vez que Castro comparece frente al tribunal, las dos ocasiones anteriores son públicas. El gobierno batistiano indicó en esta última ocasión que el reo estaba enfermo.

${ }^{87}$ Citando algunas cartas de Castro, Harnecker afirma que, "El primer gran esfuerzo de Fidel, en las duras condiciones del presidio, fue escribir y hacer salir fuera de la cárcel su autodefensa. ... [y] la tarea de su reconstrucción...”. Así, ésta advierte que el texto sale íntegro al exterior de la cárcel. Una de las citas que menciona es de una carta que Castro escribe desde la cárcel el 18 de junio de 1954 a Haydée Santamaría y a Melba Hernández (participantes del asalto al Cuartel). Aquí expresa las instrucciones en las que indica que se impriman 100,000 ejemplares del discurso con la intención de distribuirlo por toda la isla en cuatro meses (Harnecker 51-2). Interesa añadir que en una entrevista hecha a Castro durante 
una visita al Museo de Arte Romano en Mérida (1998), éste afirma que los manifiestos enviados desde la prisión "llevaban la verdad, llevaban la denuncia, desde una celda, en una prisión. ...desde donde divulgamos ideas, fuimos preparando las condiciones para nuestra lucha ulterior. [...]” (Guerra-López 291).

${ }^{88}$ Cita tomada de una de las cartas que Castro le escribe a Melba Hernández (18 de junio de 1954). La característica de Castro como defensor de la sociedad cubana, eventualmente, se convierte en un rol que desarrollan todos los combatientes de la revolución. Así, “...la sociedad pasará a estar tutelada por una nueva élite que se considera su defensora e intérprete. ...” (López-Ávalos 90). Por lo tanto, estos combatientes serán vistos como una especie de traductores de esa voluntad del pueblo. Éstos tienen el poder de ver lo que conviene o no para la sociedad. Además, hay que añadir que en el acto de escritura del ensayo está presente el reflejo de la figura de Martí, específicamente, de su empresa "heroica y callada de unir a los cubanos para la lucha” a través de la difusión escrita (Tomado de una de las cartas de Castro a Luis Conte Agüero el 14 de agosto de 1954) (Harnecker 68).

${ }^{89}$ Cita tomada de una comparecencia televisiva de Castro el $1^{\circ}$ de diciembre de 1961.

${ }^{90}$ Para añadir, es preciso mostrar que "La complejidad de la historia estriba, sin duda alguna, en su carácter abierto y, por consiguiente, inacabado. La historia se alimenta en el presente y con él lee-relee cada vez el pasado. De esta suerte, el pasado es un sistema abierto en continua complexión, en continuo acabamiento, esencialmente ilimitado o indeterminado gracias al decurso de la evolución, del tiempo, en fin, gracias a la proyección, por así decirlo, del presente hacia el futuro” (Maldonado 40). Por lo tanto, contiene en sí esa naturaleza cíclica o continua.

${ }^{91}$ Castro constantemente utiliza los mismos adjetivos para definir la revolución, al pueblo, a los insurrectos y a sí mismo. Esto es un método de persuasión dirigido al pueblo, al jurado, a los soldados del ejército, etc. Por ejemplo, éste insiste en ser poseedor de la verdad: “...ajustándome rigurosamente a los hechos, a la verdad, y a la razón, demostraré lo que acabo de afirmar” (243). Por otra parte, además éste utiliza también la constitución de 1940 para auto-defenderse y enfrentar al jurado.

${ }^{92}$ Hay que tomar en cuenta que popularmente hay quienes creen que Castro no es la persona que redacta dicho ensayo. En entrevista con varias personas cubanas, muchos consideran que éste recibe ayuda para escribir este trabajo. De todas formas, no hay manera de confirmar la veracidad de estas declaraciones pero resulta interesante mencionar la posible ambigüedad de la voz narrativa. Por lo tanto en esta investigación se asume que el autor intelectual del texto es efectivamente Castro.

${ }^{93}$ Castro no solo busca persuadir al grupo de magistrados en esa sala de Audiencia (sala de hospital) sino que también quiere disuadir a los militares que allí se encuentran. Así, apela a la humanidad del soldado (aun siendo parte de la dictadura) excusando su comportamiento - es un modo de persuasión, una retórica de su humanismo-optimista: "El soldado es un hombre de carne y hueso, que piensa, que observa y que siente. Es susceptible a la influencia de las opiniones, creencias, simpatías y antipatías del pueblo" (Castro 204-5). De este modo, se expresa una reivindicación de la imagen del soldado, una rehumanización, puesto que "le afectan los mismos problemas", tienen iguales “... necesidades, deberes y sentimientos como miembro de una familia y de una colectividad social” (205). Aunque, efectivamente, éste no deja de denunciar a quienes siguieron las órdenes de la dictadura, porque "hay militares manchados hasta el pelo con sangre de muchos jóvenes cubanos torturados y asesinados" (206). Con esto, el ponente incita al soldado, lo persuade a identificarse a sí mismo como un ser justo, igual a él y a los suyos, encarnando también la figura del héroe y del mártir: "Como quiero ser justo antes de todo, ... todo militar de honor y dignidad que ame su carrera y quiera su constitución, está en el deber de exigir y luchar para que esas manchas sean lavadas, esos engaños sean vengados y esas culpas sean castigadas si no quieren que ser militar sea para siempre una infamia en vez de un orgullo" (206-7). Esto es parte del plan retórico de Castro para lograr la adscripción de la fuerza militar a su favor al momento de derrocar a Batista. 
${ }^{94} \mathrm{El}$ autor se refiere, primero, al Grito de Yara que sucede el 10 de octubre de 1868, momento en el cual se comienza a actuar a favor de la independencia de Cuba; es el comienzo de la guerra de los 10 años. En segundo lugar, alude al Grito de Baire, inicio del levantamiento cubano en contra de la invasión española en varios puntos de Oriente el 24 de febrero de 1895.

${ }^{95}$ Periodo de gobernación de Gerardo Machado (1925-1933) que actuó de modo represivo y violento en contra de los opositores de dicha administración.

${ }^{96}$ En una intervención en el IV Congreso del Partido Comunista de Cuba, en 1991, Castro confiesa que “...fue un pensamiento moderado...”: “... acudí a mis conocimiento bíblicos y hablé de los becerros de oro y dije que los becerros de oro no hacían milagros, y que el Estado tendría que jugar su papel esencial” (Guerra-López 284).

${ }^{97}$ Napoleón vende la región de Louisiana a los Estados Unidos en 1803 (hoy día son los territorios de Arkansas, Missouri, Iowa, Oklahoma, Kansas, Nebraska, Minnesota (al sur del río Mississippi), mucha parte de Dakota del Norte, la mayoría de Dakota del Sur, el noreste de Nuevo México, el norte de Texas, parte de Montana, igual de Wyoming y Colorado y, por supuesto, Lousiana. También partes de Alberta y Saskatchewan en Canadá). Esta acción crea conflictos con la corona española, así la lucha de los espacios marítimos con Inglaterra. La alusión a Napoleón es una advertencia de la traición y de la toma de ventaja que Castro advierte en Batista.

98 Para validar el derecho a sublevarse que tienen Castro, sus compañeros y el pueblo, el texto muestra una serie de citas que apoyan sus actos de insurrección. Así, el acusado se defiende indicando que, "El derecho de rebelión contra el despotismo, señores magistrados, ha sido reconocido, desde la más lejana antigüedad hasta el presente, por hombres de todas las doctrinas, de todas las ideas y todas las creencias" (Castro 247). Éste expone varios ejemplos: monarquías teocráticas de la antigüedad china, los pensadores de la antigua India, las ciudades estados de Grecia y la República romana, en la Edad Media occidental (Salisbury), Santo Tomás de Aquino en la Summa Theologica, Martín Lutero y su discípulo Felipe Melanchton, Calvino, Juan Mariana (jesuita español de la época de Felipe II), un escritor francés llamado Francisco Hotman, otro personaje que firma bajo un seudónimo de Stephanus Junius Brutus (folleto de Vindiciae Contra Tyrannos), los escoceses Juan Knox y Juan Poynet y Jorge Buchnam, además el alemán Juan Altusio. Como indica el autor, éstos son "escritores de todas las ideas y todas las creencias", por lo tanto este derecho simplemente se encuentra "en la raíz misma de nuestra existencia política”. También añade a otros, como Juan Milton, Juan Locke, Juan Jacobo Rousseau (249-50). Además, inclusive cita la Declaración de Independencia de los Estados Unidos (1776) y la de los derechos del Hombre de Francia (250-1). Por otra parte, no basta con nombrar todos estos personajes sino que luego provee ejemplos concretos de sublevaciones de distintos pueblos. Éstos son, en Inglaterra (siglo XVII) la revolución inglesa de 1688, y en América y Francia, sus respectivas revoluciones (1775 y 1789). Así, esto sirve para ilustrar cómo las revueltas del pasado abren "el proceso de liberación de las colonias españolas en América, cuyo último eslabón fue Cuba” (249). No obstante, a pesar que para la historia cubana la lucha de la independencia en Haití, que comienza en 1791, es muy importante incluso para todo el hemisferio americano, resulta interesante que ésta no se menciona en el ensayo castrista.

${ }^{99}$ José Andrés Rivas advierte en su investigación que "el regreso al punto de partida tiene también un sentido simbólico" (Rivas 192). Castro, en su escrito comienza hablando sobre el juicio y termina o cierra en el mismo juicio. Incluso, es una referencia a "una estructura propia de cualquier novela de aventuras, en la que el personaje atraviesa una serie de peripecias y dificultades, al final de las cuales sigue siendo igual que al comienzo. En su actuación como personaje, guía o intermediario, lo que importa no es él, sino los acontecimientos de los que forma parte. ... sirve como campo de conocimiento y de pruebas. Y es al mismo tiempo el lugar en donde el personaje podrá reconocerse” (193). Aunque Rivas se refiere a una novela de Carlos Fuentes, es evidente que las mismas características pueden ser 
identificadas en este ensayo de Castro, pues éste no es únicamente guía o intérprete del pasado sino también participe y víctima de los acontecimientos.

${ }^{100}$ Según Maldonado, "la historia es ciega”... y es igualmente "un fenómeno esencialmente guiado por contingencias" (22).

${ }^{101}$ Este modo de pensamiento es de acuerdo a la escuela de los simbolistas franceses. Entre los más reconocidos están Moréas, Verlaine, Baudelaire, Mallarmé, entre otros.

${ }^{102}$ Rafael López-Pedraza menciona esto a lo largo de su ensayo, “Ansiedad Cultural”.

103 Roberto Fernández Retamar indica precisamente que Castro hace a Martí "el autor intelectual del 26 de julio” (Cultura y creación intelectual... 318).

104 Jorge Ricardo Massetti en Los que luchan y los que lloran (El Fidel Castro que yo vi) alude a esta configuración heroica de Castro incluso a partir de los eventos del Moncada. Aunque, éste narra específicamente una crónica sobre su experiencia en la Sierra Maestra en 1958.

${ }^{105}$ Por consiguiente, esto lo prepara para la posterior salida a México y, después, para su regreso y entrada a la sierra Maestra en donde desempeña cabalmente su lugar como adalid. Al lograr su lugar de líder, surge “...la figura del héroe como una especie de fuerza del ego (o, si hablamos en términos colectivos, de identidad tribual) que ya no tiene necesidad de vencer a los monstruos y los gigantes” (Jung \& Henderson 128).

${ }^{106}$ Por ejemplo, las expresiones artísticas (y políticas) están basadas en el carácter emocional del individuo, del artista, sin embargo, luego ilustra elementos que construyen una identidad plural de la cultura. Además, es posible que “...la preocupación por encontrar una identidad latinoamericana trate de expresar un anhelo de autenticidad como expresión más directa del ser,...” (López-Pedraza 18).

${ }^{107}$ Ball, aludiendo a Charles Taylor en "Political theory and practice" del libro Social Theory and Political Practice, también añade que, "If, ... our moral and political theories -including theories of justice- are more or less systematic articulations of the presuppositions and justifications of historically parochial practices, aims and aspirations, it follows that the intuitively appealing idea that one generation has a duty to act justly toward distant future generations is itself incoherent” (Ball 150).

${ }^{108}$ En este cuarto de hospital convertido en audiencia, frente al tribunal, Castro dice en 1999 que, “...tuve el placer de poder decir allí todo lo que pensaba, completo, bastante desafiante. ... ahí estaba todo. ... todos los cimientos de un programa socialista de gobierno, aunque, convencido, desde luego, de que ese no era el momento de hacerlo, que eso iba a tener sus etapas y su tiempo" (Castro 293).

${ }^{109}$ En un Discurso de Castro en Venezuela en 1999, éste asegura que "En el juicio lo que hice fue asumir mi propia defensa. ...creía que el mejor que podía defenderme en aquel momento era yo mismo;... No pretendía salir absuelto, sino divulgar ideas” (Guerra-López 292). La importancia que existe en expresar sus ideas es primordial, pues la doble intención es evidente: proyectar ideas por encima de absolverse.

${ }^{110}$ Fuente tomada del Internet, no tiene paginación.

${ }^{111}$ Como se ha indicado, estos componentes metafóricos también representan lo femenino en el ensayo de Castro (sirviendo esto como otro tropo): la historia, la revolución, la justicia, la ética. Por otra parte, lo masculino está representado en la figura del héroe que ilustra lo contrario a la feminidad: virilidad u hombría, como figura mediática que salvaguarda estos entes femeninos. Sobre esto, Sorensen indica que en Castro "Se adivina en cambio una gramática de la fraternidad, aparentemente minando el orden 
patriarcal y alimentando un orden utópico en proceso de construcción...” y en el centro de esto, "se yergue el líder y héroe revolucionario, Fidel Castro, que representa valores hipermasculinos en su relación con el cuerpo político" (Sorensen 135; mi énfasis).

${ }^{112}$ Por lo tanto, las ideologías y métodos de persuasión recurren igualmente al uso de arquetipos o figuras míticas. En Cuba, hay una conciencia marcada de las posibilidades que contiene la historia sobre las múltiples variaciones interpretativas. Esto delimita substancialmente la manera en que los estudios acerca de la historia de la revolución cubana se han desarrollado, "generando una oposición dialéctica entre la democracia y la dictadura, o entre la revolución y la contrarrevolución” (López-Ávalos 79). López-Ávalos añade que "El influjo de la Revolución cubana modificó y condicionó, sin duda alguna, la historia latinoamericana de la segunda mitad del siglo XX, no sólo por la Guerra Fría, sino también por la lectura que diversas fuerzas políticas dieron a los acontecimientos cubanos y a los que asumieron como lecciones. En este sentido queda abierta, para el análisis no sólo histórico, la importancia de la aportación cubana a la teoría revolucionaria y en específico al marxismo” (80). Así, surgen confrontaciones ideológicas de dichas dilucidaciones de los textos, "dado que la historia es vista como otro campo de batalla; la lucha por la interpretación de la historia ha polarizado" los trabajos relacionados a la revolución cubana hasta la actualidad (79; mi énfasis).

113 Castro advierte en 1991, en una intervención en el IV Congreso del Partido Comunista de Cuba que “'La historia...' es la esencia de un programa socialista” (Guerra-López 284).

${ }^{114}$ Cita tomada de: http://tiempo.infonews.com/2013/06/15/suplemento-cultura-103838-la-historiametafora-del-presente.php

${ }^{115}$ Para lograr esto, Castro apela a la honra de los magistrados, advirtiendo que al no honrar su labor jurídica, éstos mancharían "sin precedentes” el Poder Judicial.

${ }^{116}$ Corticelli, María Rita. “Antonio Benitez Rojo: en busca de una visión alternativa del Caribe”. Chen, Sham J. Actas Del Simposio Hacia La Comprensión Del 98: Representaciones Finiseculares En España E Hispanoamérica. San José, Costa Rica: Editorial de la Universidad de Costa Rica, 2001. Print.

${ }^{117}$ Refiérase a la forma en que Antonio Benítez Rojo utiliza la expresión "de cierta manera” en La isla que se repite, trabajada aquí en el sexto capítulo.

${ }^{118}$ El sistema colonial no solo reconoce que debe haber una dinámica paralela en el proceso de adaptación a una nueva manera de producción económica, sino que igualmente es consciente de la posibilidad de que estos esclavos puedan sublevarse. Por esto, se permite ciertos tipo de actividades libres para mantener al esclavo ocupado mientras no están en su faena laboral (The Development... Brathwaite 298).

${ }^{119}$ Brathwaite nombra los distintos patrones de criollización durante estos periodos de formación. Los patrones son los siguientes: (1) los blancos: la alteración de sus pensamientos de manera imperceptible; (2) los esclavos: la ruta del esclavo o "the middle passage", el lugar de donde vienen y ulteriormente el periodo de seasoning; (3) socialización: las rutinas y la identificación con el grupo, comunalización, proceso social voluntario e involuntario (natural). La socialización se diseña para buscar mayor control del proceso de producción de la plantación; (4) imitación: la adquisición de destrezas y conocimiento de las labores civiles a través de ver y escuchar (por ejemplo las obras teatrales). Con esto también la ambivalencia creativa. (The Development... Brathwaite 298-9)

${ }^{120}$ Se trata de la relación que existe a partir de la globalización. Las conexiones entre países del 'tercer mundo' con los del 'primer mundo'.

${ }^{121}$ Esto se asemeja con lo que más adelante se expone en el análisis sobre Jiménes-Grullón acerca de la música. Aquí, Brathwaite lo alude en varias citas. 
${ }^{122}$ En su trabajo, Brathwaite hace una minuciosa mención y división de las distintas particularidades de la criollización. Nombra algunas como euro-criollas ('Euro-creole’) y mulato-criollas ('mulato-creole'), entre otras.

${ }^{123}$ Por supuesto, la influencia de los norteamericanos en el Caribe difiere de la de otros grupos culturales. Esto es, como ya es sabido, las condiciones por las que estos grupos viajan a las islas caribeñas difieren en extremo. Los norteamericanos no se establecen en el Caribe para ofrecer mano de obra laboral sino, al contrario, para ejercer su dominio como nueva potencia imperial. Por supuesto, esto no impide una influencia en la mezcla cultural que va desarrollándose en este espacio.

${ }^{124}$ Refieráse al capítulo 2 de este trabajo.

${ }^{125}$ De forma paralela a cómo Benedict Anderson advierte las comunidades imaginadas en su conocido libro.

${ }^{126}$ Webster cita a L. Ferguson en Uncommon Ground: Archaeology and Early African America, 16501800. Washington, D.C.: Smithsonian Institution Press, 1992.

${ }^{127}$ Kneeper se refiere específicamente a los trabajos sociológicos del martiniqués Rafael Confiant.

${ }^{128}$ Rizvi expone estas ideas de acuerdo a las premisas de Stuart Hall (1991).

${ }^{129}$ No obstante, en Brathwaite también puede tratarse de una compensación, aunque ésta no es vista como decurso natural de los eventos sino que, dentro de las estructuras europeas impuestas, no-naturales, la sociedad y el entorno (la realidad) se transforma, configurándose así la criollización como flujo cultural en el Caribe.

${ }^{130}$ Es interesante notar que la expresión espiritual según el autor, está ligada con la integracióndesintegración social y al ‘sentimiento’ nacionalista, específicamente, de la dominicanidad.

${ }^{131}$ Por cierto, el autor afirma que "Lo fue hasta el momento en que se produjo la invasión de Louverture" (223).

${ }^{132}$ Lo liminal en Castro se observa de acuerdo a cómo Victor Turner define el término.

${ }^{133}$ Un ejemplo que Brathwaite señala es que Sylvia Wynter crea distinciones entre el término 'creolization' y el de 'indigenization': "an inescapable aspect of the creolization process which is both imitation (acculturation) and native creation ('indigenization'); ... our real/apparent imitation involves at the same time a significant element of creativity, while our creativity in turn involves a significant element of imitation”. Sin embargo, Brathwaite sugiere que no es necesario señalar diferencias entre una noción y otra como lo hace Wynter.

${ }^{134}$ Sin embargo, el componente pisicológico y ese dinamismo subyacente en cada una de las clases varían según el sistema ejerce el control: “...given the plantation structure, the only imitation posible was 'white', and that even this was limited and censored according to what was availbable from a spiritually stunted elite, and what was permitted under the cannons of social control" ("Contradictory...", Brathwaite 16).

${ }^{135}$ La cultura de los indígenas, sobre todo en el resto de América, participa de una dinámica semejante, ya que paralelamente existe el sentimiento de añoranza, el apego a sus tierras y a los modos de vida del pasado, así como el recuerdo de sus ancentros. 
${ }^{136}$ En la versión electrónica del texto la cita se toma de la página 207.

${ }^{137}$ Este concepto fue desarrollado por Ferguson (1959) y Fishman (1971) para describir una situación en la que existen por separado dos o más variedades de lenguajes, cada uno con funciones propias específicas en la sociedad (Devonish 9).

${ }^{138}$ Para los propósitos de este trabajo se utilizará el término créole en lugar de criollo. Esto, de acuerdo a la designación más común de este lenguaje a lo largo del Caribe.

${ }^{139}$ Entre los lingüistas más reconocidos que trabajaron esta teoría, están Lucien Adam, Thompson, John Reinecke, Joe Dillard e Ian Hancock.

${ }^{140}$ Algunos teóricos que promovieron esta idea son F. Adolpho Coelho, Schuchardt y Hesseling. A su vez, éstos se influencian de los estudios neurológicos, genéticos y evolutivos de Mendel, De Vries e incluso Darwin.

${ }^{141}$ Los estudiosos que se enfocaron en esta teoría son Kroeber y Herskovits, que acuñaron términos como difusión cultural y aculturación.

142 Para entender el contexto histórico y las razones del por qué estos adultos se comunicaban en un pidgin y no en su primera lengua africana, refiérase al trabajo de Bickerton. En específico, Bastard Tongues, 2008.

${ }^{143}$ Aunque el créole de léxico francés se utiliza por la mayoría como medio de comunicación informal, existe en Dominica el uso de una minoría de un créole de léxico inglés. El inglés es el idioma oficial de ambas islas (St. Lucía y Dominica) hace más de dos siglos.

${ }^{144}$ En las islas en las que se habla el créole con léxico inglés, éste no se considera como un lenguaje sino como dialecto, por lo tanto, crear una política de idioma oficial que incluya el créole, para muchos, no es viable (Devonish 87).

145 Surinam tiene una gran variedad lingüística. Existen idiomas que provienen de las familias lingüísticas del arahuaco y otras lenguas caribes, idiomas hablados por los amerindios que habitan en la isla. También existe el sarnami hindustaní (o hindustaní caribeño) que se asocia con la población proveniente de la India. Al mismo tiempo, el javanés es otra lengua utilizada pero solo por una minoría de herencia indonesia, así como también otros lenguajes de los negros marrones como el saramaccan, djuka y aluka. Sin embargo, sigue siendo el sranan el idioma de mayor uso en el país puesto que es la forma de comunicación que tienen en común todas estas minorías culturales: "With the arrival during the postslavery period of East Indians, Indonesians, and Chinese as indentured labourers, Sranan emerged as the lingua franca for communication between members of the various linguistic communities which then found themselves co-existing in the same society” (Devonish 69).

${ }^{146}$ Este es probablemente el idioma que tiene un uso más amplio en todo el Caribe. No solo es la lengua utilizada en la esfera privada para la mayoría de la población, sino que también "it is the major medium of public communication in these islands” (Devonish 65). Sin embargo, el holandés es el idioma oficial de las islas puesto que es el idioma usado en la administración pública.

${ }^{147}$ Existen variadísimas formas de ortografía créole. Durante la colonización se desarrollaron varios sistemas de escritura, mayormente por las Iglesias. Éstas reconocieron que para llegar a la masa debían educar a la población y el medio de comunicación debía ser el créole. Luego, por ejemplo en el caso de Guadeloupe, la escritura del créole se utilizó para la lucha pro independencia a mediados del siglo XX. Grupos en favor del comunismo y la independencia apoyaron la clase trabajadora agrícola en sus luchas en contra del gobierno. De ahí surgen dos tipos de escritura, reconociendo uno de ellos como el de 
mejor representación fonológica del créole. Éste último fue diseñado por el académico Jean Bernabé (quien aporta también a la propuesta de la creolité). Para más información sobre estos sistemas de escritura créole referirse al texto de Devonish, en particular, desde las páginas 79 a la 86.

${ }^{148}$ Glissant dice que esto es así, específicamente, porque en el Caribe no existen las estaciones del año.

${ }^{149}$ Precisamente, en el próximo capítulo se analizan las propuestas de Pedreira y Benítez Rojo acerca de la geografía insular.

${ }^{150}$ Frankéttiene es un escritor haitiano que redacta Dézafi (1975), la primera novela escrita en lengua créole haitiana.

${ }^{151}$ Estas relaciones también se dan entre los demás idiomas oficiales de las islas y el creole (por ejemplo, entre el inglés y el creole, el holandés y el creole, y demás.).

${ }^{152}$ El autor llama macrosistema al fenómeno de la Plantación dado a que, dentro de éste, existen influjos de otros grandes sistemas. Para Benítez Rojo, la Plantación es una de las máquinas más importantes (partiendo del concepto de Deleuze y Guatari, es decir, como una cadena de máquinas acopladas) de flujos e interrupciones en el Caribe.

${ }^{153}$ Las máquinas en el Caribe, en el sentido de Deleuze y Guattari mencionado en la nota anterior, de acuerdo a Benítez Rojo, se acoplan, por ejemplo, a partir de 1492 con la llegada de Cristóbal Colón, luego con la colonización de Hernán Cortés, la creación del sistema de flotas propuesto por Pedro Menéndez de Avilés, la continua colonización desde México hasta Perú, y demás, y la creación del sistema de la Plantación. Por esto, el Caribe no solo es parte del flujo de máquinas sino también su productor (25-8).

${ }^{154}$ Glissant, en el discurso antillano propone, igual que Benítez-Rojo, el Caribe como un texto que se reinterpreta constantemente.

${ }^{155}$ El autor indica esto dando ejemplos concretos de modos de actuación o representación, tales como el boxeo, la música, el baile y la escritura (Benítez-Rojo 43).

156 Juan Flores indica, en Insularismo e ideología burguesa en Antonio Pedreira (1980), que lo expuesto por Pedreira en su ensayo advierte un conformismo burgués y que, incluso, es otra versión del “puertorriqueño dócil” de René Marqués.

${ }^{157}$ Benítez Rojo explica en un apartado final de su libro (2010) cómo se desarrollaron los estudios sobre la perspectiva del Caos (403-408). Para una detallada explicación refiérase al libro. En particular, Mandelbrot fue un matemático que se distinguió por el estudio de los fractales. Inclusive, fue reconocido como el responsable del auge de estos estudios.

158 Tomado del artículo "Cubaneos: resolver, un verbo cubano" de Gilberto Dihigo en: $<$ http://dihigo.blogspot.com/2011/07/cubaneos-resolver-un-verbo-cubano.html>.

${ }^{159}$ Para un análisis de la función del idioma en la cultura del Caribe, refiérase al capítulo quinto de este trabajo.

${ }^{160}$ Mi traducción.

${ }^{161}$ El texto de Discours Antillais se analiza en el capítulo anterior de este trabajo. Para un mayor énfasis de la propuesta glissantiana refiérase al capítulo 5 . 
${ }^{162}$ Añado una breve lista de algunas de las mujeres ensayistas del siglo XX caribeño: En el Caribe hispano están Lydia Cabrera (cubana), María Teresa Babín (puertorriqueña), Ana Lydia Vega (puertorriqueña), Iris Zavala (puertorriqueña), Aurora Tavárez Belliard (dominicana), Ángela Hernández (dominicana), entre otras más. En las Antillas de habla inglesa, están autoras como Sylvia Wynter (jamaiquina nacida en Cuba), Amy Bailey (jamaiquina), Amy Jacques-Garvey (jamaiquina), Jamaica Kincaid (Antigua), y más. En las Antillas francesas se incluye a Maryse Condé (Guadeloupe; sin embargo aquí escribe en inglés), Suzanne Césaire (Martinique) y otras. 


\section{Referencias:}

Adorno, Theodore. "El ensayo como forma". Notas sobre Literatura. Madrid: Ediciones Akal, 2009. 11-34.

Appadurai, Arjun. "Introduction: commodities and the politics of value”. The Social Life of Things: Commodities in Cultural Perspective. Cambridge: Cambridge University Press, 1986. 3-63.

Arrizón, Alicia. "Race-ing Performativity through Transculturation, Taste and the Mulata Body”. Theatre Research International 27.2 (2002): 136-52.

Arroyo, Jossianna. "Travestimos culturales: tropicalismo y transculturación en Gilberto Freyre y Fernando Ortiz”. Estudios: Revista de Investigaciones literarias y culturales 10.19 (2002). 11-34.

Ashcroft, Bill, Gareth Griffiths, and Helen Tiffin. The Empire Writes Back: Theory and Practice in Post-Colonial Literatures. London: Routledge, 1989.

Benítez Rojo, Antonio. La isla que se repite. San Juan: Editorial Plaza Mayor, 2010.

Bhaba, Hommi. El lugar de la cultura. Trad. César Aira. Buenos Aires: Ediciones Manantial, 2002.

-----------------. The Location of Culture. New York: Routledge, 1994.

Bickerton, Derek. Bastard Tongues. New York: Hill and Wang, 2008. Print.

Bickerton, Derek, Francis Byrne, and Thom Huebner. Development and Structures of Creole Languages: Essays in Honor of Derek Bickerton. Amsterdam: J. Benjamins Pub, 1991. Print.

Borges, Jorge Luis. “La metáfora”. Textos recobrados 1919-1929. Buenos Aires: Emecé Editores, 1997. 114-20.

81.

-. “Examen de metáforas”. Inquisiciones. Madrid: Alianza Editorial, 1998. 70-

Brathwaite, Kamau. Caribbean Man in Space and Time. A Bibliographical and Conceptual Approach. Mona: Publicaciones Savacou, 1974.

-----------. Contradictory Omens. Cultural Diversity and Integration in the Caribbean. Mona: Publicaciones Savacou, 1985.

---------. “Metaphors of Underdevelopment”. The Art of Kamau Brathwaite. Wales: The Cromwell Press, 1995. 
---------. The Development of Creole Society in Jamaica 1770-1820. Kingston: Ian Randel Publishers, 2005.

Bunge, Carlos Octavio. Nuestra América Buenos Aires: Casa Vaccaro, 1918. 118.

Cavallín Calanche, Claudia. "Posibilidades de la metáfora en Borges” Atenea (Concepión) 498 (2008): 45-54. Tomado el 6 de diciembre de 2010 de: $<$ http://www.scielo.cl/scielo.php?script=sci_arttext\&pid=S0718-

04622008000200004\&lng=es\&nrm=iso>. ISSN 0718-0462. doi: 10.4067/S0718$04622008000200004>$.

Césaire, Aimé. “Discurso pronunciado en Dakar el 6 de abril de 1966”. Gradhiva 10 (2009). Puesto en línea el 5 de febrero del 2010. Tomado el 19 de mayo de 2013 de: http://gradhiva.revues.org/1604

Entrevista . La négritude. Césaire et Senghor". Video Le cercle de minuit, France 2. Entrevista realizada el 9 de febrero de 1994. Tomado el 21 de febrero de 2013 de http://www.ina.fr/notice/voir/I05329806

“------. “Négreries: Jeunesse et assimiliation”. L'étudiant noir 1.1 (1935). 3. The Center for Research Library, 2008. Tomado el 11 de julio de 2012 de: http://dds.crl.edu/CRLdelivery.asp?tid=6590

- “Négritude et Humanisme”. Aimé Césaire: Le Discours Sur La Negritude, Miami (Florida International University 1987). Fort-de-France, Martinique: Conseil général de la Martinique, Bureau de la communication et des relations avec la presse, 2003.

Chakrabarty, Dipesh. Provincializing Europe. Postcolonial Thought and Historical Difference. Princeton and Oxford: Princeton University Press, 2008.

Comas, Juan y Berta Becerra. "La obra escrita de Don Fernando Ortiz". Revista Interamericana de Bibliografia, VII num. 4 (oct.-dic. 1957), 350. La bibliografía de Fernando Ortiz incluida en este trabajo, hecha por la Dra. Berta Becerra, aparece tambien en la Revista Bimestre Cubana, LXXIV (enero-junio), 1958.

Condé, Maryse. “Order, Disorder, Freedom, and the West Indian Writer”. Yale French Studies 97.2 (2000). 151-165.

Confiant, Rafael. Aimé Césaire : Une traversée paradoxale du siècle. Paris: Ecriture, 2006.

Confiant, Rafael; Patrick Chamoiseau y Jean Bernabé. Éloge de la Creolité. Paris: Gallimard, 1989. Print.

Cornejo Polar, Antonio. "Mestizaje e hibridez: Los riesgos de las metáforas. Apuntes." Revista de Crítica Literaria Latinoamericana 24.47 (1998). 7-11. 
-------------. "El indigenismo y las literaturas heterogéneas: Su doble estatuto sociocultural”. Revista de Crítica Literaria Latinoamericana 4. 7/8 (1978). 7-21

Coronil, Fernando. "Introduction to the Duke University Press Edition Transculturation and the Politics of Theory: Countering the Center, Cuban Counterpoint”.

Coulthard, George R. “Négritude — Reality and Mystification”. Río Piedras: Caribbean Studies 10.1 (Abril 1970): 42-51.

Damas, León G. Poètes d'expression française 1900-1945. Paris: Éditions du Seuil, 1947.

De Toro, Alfonso. "Figuras de la hibridez. Fernando Ortiz: Transculturación. Roberto Fernández Retamar: Calibán”. Alma cubana: transculturación, mestizaje e hibridismo. Ed. Susanna Regazzoni. Frankfurt, Madrid: Vervuert \& Iberoamericana, 2006. 15-35.

Depestre, René: “Buenos días y un adiós a la negritud”. La Habana: Cuadernos Casa de las Américas 29 (1987). 39.

Devonish, Hubert. Language and Liberation: Creole Language Politics in the Caribbean. London, U.K: Karia Press, 1986. Print.

Diagne, Souleymane. “Négritude”, The Stanford Encyclopedia of Philosophy (Summer 2010 Edition). Edward N. Zalta (ed.). Tomado el 11 de diciembre de 2010 de: $<$ http://plato.stanford.edu/archives/sum2010/entries/negritude/>.

Díaz Quiñones, Arcadio. “De cómo y cuándo bregar”. El arte de bregar. San Juan: Ediciones Callejón, Inc. 2003. 19-87.

----------. “Caribe y exilio en La isla que se repite de Antonio Benítez Rojo”. Orbis Tertius, 2007 12(13).

------------. Sobre los principios: los intelectuales caribeños y la tradición. Buenos Aires: Universidad Nacional de Quilmes Editorial, 2006.

Dihigo, Gilberto. “Cubaneos: resolver, un verbo cubano”. Tomado el 26 de octubre de 2014 de: <http://dihigo.blogspot.com/2011/07/cubaneos-resolver-un-verbo-cubano.html>.

Fanon, Franz. Peau noire, masques blancs. Paris: Points French - Points essais edition, 1971.

Foucault, Michel. Vigilar y castigar. Buenos Aires: Siglo Veintiuno editores, 2002.

Fargas y Soler, Antonio. Diccionario de música: ó sea explicación y definición de todas las palabras técnicas del Arte y de los instrumentos músicos antiguos y modernos segun los mejores diccionarios publicados en Francia Italia y Alemania. Barcelona:Imprenta de Joaquin Verdaguer, 1852. 52-3. 
Fernández, Retamar R. Caliban and Other Essays. Minneapolis: University of Minnesota Press, 1989. Print.

Ferrada A. Mineduc, Ricardo. “Aimé Césaire. Acción poética y negritud”. Literatura y lingüística 13 (2001). Tomado el 12 de abril de 2013 de:

http://www.scielo.cl/scielo.php?script=sci_arttext\&pid=S0716-58112001001300009

Foucault, Michel. Historia de la sexualidad I. La voluntad de Saber. Madrid: Siglo Veintiuno de España Editores, 1998. Tomado de: http://biblioteca.d2g.com

García-Platero, Juan Manuel. “Observaciones sobre el neologismo”. Revista de Lexicografía 11 (1995-1996). 49-59.

Garraway, Doris L. "What Is Mine": Césairean Negritude between the Particular and the Universal”. Research in African Literatures 41.1, (Spring) 2010. 71-86.

Garrido-Castellano, Carlos. "Nuevos mediterráneos, nuevas Helenas. Mito e historia en la representación femenina. Una mirada desde el arte caribeño actual”. El mito de la mujer caribeña. Madrid: Ediciones de La Discreta, 2011. 127-37.

Glissant, Édouard. Caribbean Discourse: Selected Essays. Charlottesville: University Press of Virginia, 1989. Impreso.

. Poétique De La Relation. Paris: Gallimard, 1990. Impreso.

Godoy, Gustavo J. "Fernando Ortiz, las Razas y los Negros”. Journal of Inter-American Studies 8. 2 (1966). 236-244

Gómez-Martínez, José Luis. Teoría del ensayo: http://www.ensayistas.org/critica/ensayo/gomez/

Gónzalez, Marianela. "Maryse Condé en La Habana: 'Si la vida no fuese mágica, no existiría la escritura””. La Jiribilla. La Habana: año IX; 20-26 de noviembre de 2010. Tomado el 29 de octubre de 2014 de < http://www.lajiribilla.co.cu/2010/n498_11/498_22.html>

Duno-Gottberg, Luis. Solventando las diferencias: la ideología del mestizaje en Cuba. Madrid: Iberoamericana,Frankfurt am Main: Vervuert, 2003. Online.

Hopenhayn, Martín. “Globalización y cultura: cinco miradas para un solo texto”. Ponencia para el XX Congreso de LASA, Guadalajara, México, 17 al 19 de abril de 1997.

Ibarra, Jorge. “La herencia científica de Fernando Ortiz”. Revista Iberoamericana. 1339-51.

Iser, Wolfgang. “El proceso de lectura”. 149-164. 
Jaspers, Karl. Philosophy of Existence. Philadelphia: University of Pennsylvania Press, 1971. 63-94.

Jiménes-Grullón, Juan Isidro. La República Dominicana: una ficción. Mérida, Venezuela: Talleres Gráficos Universitarios, 1965.

Josephs, Kelly Baker. "Versions of X/Self: Kamau Brathwaite's Caribbean Discourse”. Anthurium: A Caribbean Studies Journal 1.1, 2003: 1-15. Tomado el 3 de marzo de 2014 de: <http://scholarlyrepository.miami.edu/anthurium/vol1/iss1/4>.

Knepper, Wendy. "Colonization, Creolization, and Globalization: The Art and Ruses of Bricolage”. Small Axe 21, 2006: 70-86

Kopytoff, Igor. “The cultural biography of things: commodization as process”. The Social Life of Things: Commodities in Cultural Perspective. Cambridge: Cambridge University Press, 1986. 64-94.

Lamming, George. The pleasures of exile. Ann Arbor: University of Michigan Press, 1992. Print.

Lavie, Smadar, y Ted Swedenburg. Displacement, Diaspora, and Geographies of Identity. Durham: Duke University Press, 1996.

Lefebvre, Henri. The Production of Space. Cambridge: Blackwell Publishers Ltd.,1991.

-----------------. “La producción del espacio”. Revista de sociología 3 (1974). 219-229.

Lévinas, Emmanuel. Ethics and infinity. Pittsburgh: Duquesne University Press, 1985.

Lewis, Gordon K. Main Currents in Caribbean Thought: The Historical Evolution of Caribbean Society in Its Ideological Aspects, 1492-1900. Baltimore: Johns Hopkins University Press, 1983. Impreso.

Miller, Christopher L. "The (Revised) Birth of Negritude: Communist Revolution and "the Immanent Negro” in 1935”. PMLA 125.3 (2010). 743-9.

Mintz, Sidney W, y Richard Price. The Birth of African-American Culture: An Anthropological Perspective. Boston: Beacon Press, 1992. Print.

Naranjo-Orovio, Consuelo. "Cultura, identidad y nación en las obras de Fernando Ortiz y Antonio S. Pedreira”. Madrid: CSIC (Digitalización en el 2006)

Orrengo, Francisco. “De la isla al archipiélago en el Mundo Hispano”. Revista austral ciencias sociales [online] 19 (2010): 119-24. Tomado el 20 de octubre de 2014 de:

$<$ http://mingaonline.uach.cl/scielo.php?script=sci_arttext\&pid=S0718$17952010000200008 \& \operatorname{lng}=e s \& n r m=i s o>$. ISSN 0718-1795> . 
Ortiz, Fernando. Contrapunteo cubano del tabaco y el azúcar. Madrid: Ediciones Cátedra, 2002. Print.

\footnotetext{
(1951). 195.
}

. "El quinto jinete del Apocalipsis". Revista Bimestre Cubana LXVII.3

Paz, Octavio. Los hijos del limo. México: Ediciones Seix Barral,1974. 127

Rama, Ángel. Transculturación narrativa en Latinoamérica. Buenos Aires: Ediciones El Andariego, 2008.

Ramos Pérez, Arturo A. Globalización y Neoliberalismo: ejes de la reestructuración del capitalismo mundial y del estado en el fin de siglo XX. México: Plaza y Valdés editores, 2002

Ricoeur, Paul. The Rule of Metaphor. The creation of meaning in Language. Londres y Nueva York: Routledge. Edición de Taylor \& Francis e-library, 2004.

Rizvi, Fazal. "Mobile Minds". Globalizing the Research Imagination. Jane Kenway y Johannah Fahey, eds. Londres y New York: Routledge, 2009.

---------. “The arts, education and the politics of multiculturalism”. Culture, Difference and the Arts. Sydney: Allen \& Unwin, 1994. 54-85.

Rosello, Mireille. ““'One More Sea to Cross:” Exile and Intertextuality in Aimé Césaire’s Cahierd'un retour au pays natal”. Yale French Studies 83 (1993). 176-195.,

Said, Edward. Orientalism. New York: Pantheon Books, 1978. Print.

---------------. Culture and Imperialism. New York: Vintage Books, 1994.

San Miguel, Pedro L. La isla imaginada: Historia, identidad y utopía en La Española. San Juan y Santo Domingo: Isla Negra y La Trinitaria, 1997. Print.

Sastre, Inés. "Campesinado, escritura y paisaje: algunas cuestiones sobre el mundo provincial romano occidental”. Gerión Vol. Extra, 2007: 375-81.

Soyinka, Wole. Myth, Literature, and the African World. Cambridge: Cambridge University Press, 1976. Impreso.

------------. “Wolé Soyinka jugé Léopold Sédar Senghor et la Négritude”. Video: Un siècle d'écrivain. Bird Communication, France 3 Lille Nord-Pas de Calais. 21 de febrero de 1996. Tomado el 25 de febrero de 2013 de:

http://www.ina.fr/notice/voir/I05334919

Tomlinson, John. Globalization and Culture. Chicago: University of Chicago Press, 1999. 
Toumson, Roger y Simone Henry-Valmore. Aimé Césaire, le Négre inconsolé. París: Syros 1993.

Valdés, Mario J. "Paul Ricœur”. The Columbia History of Twenty-Century French Thought. New York: Columbia University Press, 2006. 643-7.

Webster, Jane. "Creolizing the Roman Provinces". American Journal of Archaeology 105. 2, 2001: 209-225.

Weinberg, Liliana. “Ensayo y transculturación”. Cuadernos Americanos 96 (2002). 31-47.

White, Hayden V. Tropics of Discourse: Essays in Cultural Criticism. Baltimore: Johns Hopkins University Press, 1978.

Zavala, Iris. "The Caribbean: A Common Discourse? Or the Burden of Amontillado (An Essay in Critical Fiction)”. Latin American Postmodernisms. Amsterdam - Atlanta: Rodopi, 1997. 127-39 
VITA

DIANA M. GRULLÓN-GARCÍA

Born, Río Piedras, Puerto Rico

1998-2006

B.A., Comparative Literature and Art History

University of Puerto Rico

Río Piedras, Puerto Rico

2007-2008

M.A., Latin American Literature (Spanish)

Florida International University

Miami, Florida

2007-2008

Graduate Assistant of Spanish

Florida International University

Miami, Florida

2009-2014

Teaching Assistant of Spanish

Florida International University

Miami, Florida

2011

Graduate Certificate in Latin American and Caribbean Studies

2010-2015

Doctoral Candidate of Spanish

Florida International University

Miami, Florida

\section{PUBLICATIONS AND PRESENTATIONS}

Presentation: “El intercambio simbólico de la 'realidad' en Sobre mi cadáver de Marta AponteAlsina.” XXXIII International Congress of Latin American Studies Association (LASA): "Precariedades, exclusiones, emergencias”. San Juan, Puerto Rico.

May 27-30, 2015. Accepted.

Presentation: “La 'transculturación’ de Ortiz como metáfora cultural de las relaciones de poder en el Caribe.” The Cuban Research Institute of Florida International University 10th Conference on Cuban and Cuban American Studies: "More Than White, More Than Mulatto, More Than Black": Racial Politics in Cuba and the Americas. Miami, Florida. February 26-28, 2015.

Presentation: "La historia como metáfora cultural y espacio liminal en "La historia me absolverá” de Fidel Castro.” 39th Annual Caribbean Studies Association Conference. Mérida, México. May 26-30, 2014. 
Presentation: "El romanticismo transcontinental de Gómez de Avellaneda en La velada del helecho o el donativo del Diablo.” The Department of Modern Languages and the Cuban Research Institute of Florida International University Conference: "The 200th Anniversary of the Birth of Gertrudis Gómez de Avellaneda: A Celebration of Nineteenth-Century Cuban Literature.” Miami, Florida. April 4, 2014.

Publication: "El Caribe ajeno-cotidiano y la literatura puertorriqueña de hoy en Barra china de Núñez Negrón.” El Post Antillano. May 25, 2013.

$<$ http://www.elpostantillano.net/pagina-0/criticaliteraria/5879-diana-m-grullon.html>

Publication: "Négritude”, Insularismo y Discurso sobre el colonialismo: modelos culturales caribeños en Césaire y Pedreira.” El Post Antillano. March 30, 2013.

<http://www.elpostantillano.net/pagina-0/critica-literaria/5045-diana-m-grullon.html>

Presentation: "Price-Mars, Henríquez Ureña y CLR James: modelos culturales de la identidad caribeña.” 37th Annual Caribbean Studies Association Conference. Le Gosier, Guadeloupe. May 28-June 1, 2012.

Presentation: “Négritude”, Discurso Sobre el colonialismo e Insularismo: Modelos culturales caribeños en Césaire y Pedreira.” International Conference of Afro and Latin American Studies. San Juan, Puerto Rico. March 21-24, 2012.

Presentation: "Resistencias, reconstrucciones y proyectos de identidad en Ramón Emeterio Betances y en ‘Nuestra América’ de José Martí.” XI Congreso Internacional de Literatura Hispánica. Cusco, Perú. March 7-9, 2012.

Presentation: "Carpentier, Césaire y Buñuel: sus construcciones discursivas localizadas en una deslocalización.” 1st International Congress of the Spanish Association of theory and Literature. Granada, Spain. January 26-28, 2011.

Publication: "Carpentier y lo real maravilloso en El reino de este mundo como 'producto de traducción’ que define la transculturación americana.” Tinkuy: Entre las “ruinas” y la descolonización: reflexiones desde la literatura del Gran Caribe 13 (Jun., 2010): 191-99. <http://www.littlm.umontreal.ca/recherche/documents/TINKUY13.pdf>

Presentation: "La ciudad de San Juan: bastión y retrato trasnacional caribeño en Redentores de Zeno Gandía." 2nd International Conference on Caribbean Studies (ICCS) at Universidad de Cartagena. Cartagena, Colombia. March 15-19, 2010.

Publication: "Tres representaciones fílmicas de la carencia femenina como espacio liminal en Buñuel, Bemberg y Biraben.” Hispanet Journal 3 (2010).

<http://www.hispanetjournal.com/TresRepresentaciones.pdf>

Publication: "La tradición platónico-aristotélica y La simulación de Severo Sarduy en Sirena Selena vestida depena de Mayra Santos-Febres.” Hispanet Journal 1 (2008). $<$ http://www.hispanetjournal.com/LatradicionplatonicoEDITADO.pdf> 